\title{
THE DYNAMICS OF EXCLUSIONARY CONSTITUTIONALISM: ISRAEL AS A JEWISH AND DEMOCRATIC STATE
}

\author{
MAZEN MASRI
}

\begin{abstract}
A Dissertation SubMitTed to the FACUlTy of Graduate Studies IN PARTIAL FUlfillmeNT OF THE REQUIREMENTS FOR THE DEGREE OF DOCTOR OF PHILOSOPHY
\end{abstract}

GRADUATE PROGRAM IN LAW OSGOODE HALL LAW SCHOOL YORK UNIVERSITY

TORONTO, ONTARIO

SEPTEMBER 2013

(C) MAZEN MASRI, 2013 


\begin{abstract}
This dissertation examines the meaning and implications of Israel's constitutional definition as "a Jewish and democratic state" focusing on constitutional theory. It seeks to explore how this definition is used to justify, protect and regenerate certain features of Israeli constitutional law that exclude the Palestinian Arab citizens of Israel from the processes of generating and exercising political power within the state. It argues that while the trend is to accord nominal inclusion to the Palestinian minority through formal citizenship and a measure of civil and political rights, in effect, and through the operation of the constitutional order, the Palestinian citizens are excluded from the People - the People understood as the political community underpinning the constitutional order. Given this exclusion from founding and participating in the constitutional order, the nature of the regime in Israel cannot be seen as truly democratic.

The dissertation approaches the meaning of the "Jewish and democratic" definition of the state through the question of "who is the People in Israel?". The focus on the idea of the People is rooted in its importance in constitutional theory. Many schools of thought in constitutional theory see the People as the basis of the constitutional edifice. The People holds constituent power, and exercises sovereignty to create the constitutional order which regulates the internal ordering of the state and the relationship between the state and the individuals. The People here is the "self" of the "self-rule" of democracy. The dissertation examines who is considered to be the People in Israel through the prism of the broader constitutional order. The dissertation focuses on four particular aspects that are central to constitutionalism. First is the founding stage of the constitutional order. The second is the citizenship and immigration laws and policies that shape the People. Third is political representation. The final aspect is constitution-making and law-making. An examination of these four aspects of the constitutional order reveals the dynamics of exclusionary constitutionalism that are fuelled by the Jewish definition of the state. The dissertation also explores the role of the colonial reality in creating and maintaining the dynamics of exclusionary constitutionalism.
\end{abstract}




\section{ACKNOWLEDGEMENTS}

This project would not have been possible without the many people who provided their support in many different ways. I would especially like to thank Bruce Ryder, my supervisor, for the generous support and the invaluable guidance he provided throughout my studies. Bruce was always very generous with his time, knowledge and skills. He is a great supervisor whose style struck an excellent balance between support and challenge, guidance and freedom, and finally, academic rigour and support for innovative thinking. Bruce has pushed me to develop my ideas to achieve their full potential, and he did so in his friendly and gentle way that very few can consistently maintain. He is indeed a great mentor and a friend as well.

Another friend and mentor I want to thank is Susan Drummond, who was a member of the supervisory committee. I had long discussions with Susan that were very helpful in developing my thinking. I have benefitted from her insights and wealth of knowledge. Susan did not spare any effort in helping and supporting me in my different endeavours and was always willing to help even during her vacations. I was also lucky and privileged to be part of her efforts to defend academic freedom at York University.

Thanks also to Faisal Bhabha, the third member of my supervisory committee. I am very thankful for his insightful comments and for his time and effort in reviewing the dissertation despite the tight timelines. I am grateful for the members of the examination committee, Michael Lynk, Sabah Al-Nasseri, and Obi Okafor for their enlightening questions and comments. 
I have had the good fortune of being part of a vibrant academic community at Osgoode Hall Law School and Toronto in general. In particular, I would like to thank Sujith Xavier (my library buddy for over two years) for his comments, feedback and long engaging discussions. Similarly, I would like to thank Claire Mummé, Amar Bhatia, Shanthi Senthe, Amaya Alvéz-Marín, Irina Ceric, Mai Taha, Charis Kamphuis and Stu Marvel for their help and support over the years. Special thanks also go to Sharry Aiken, Jens Hanssen, Peer Zumbansen, Annie Bunting, and Hengameh Saberi for their help during various stages of this journey.

Last but not least, I would like to thank my family for their loving support and encouragement over the years, and for instilling in me a healthy intellectual curiosity and the love of learning, and my partner Ryvka for her love and support. 


\section{Table of Contents}

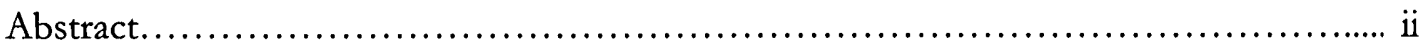

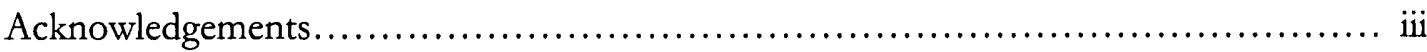

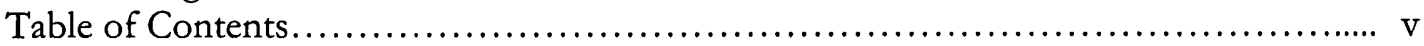

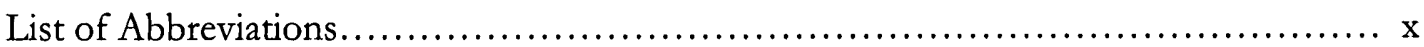

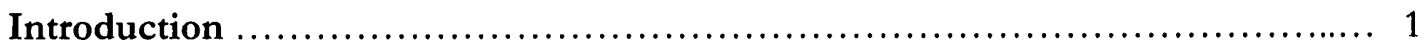

Social, Political and Historical Context...................................... 5

Israel as a Jewish and Democratic State...................................... 10

Outline of the Dissertation.............................................. 16

Distinctive Contribution to the Literature.................................. 19

\section{Chapter I}

The People and their Constitution: Theoretical Approaches to Constitutionalism,

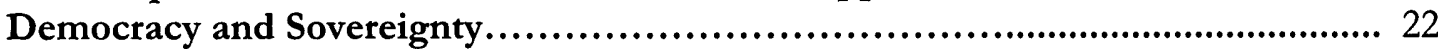

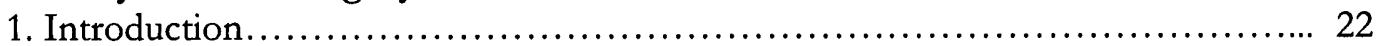

2. Beginnings: Political Ordering, Constituent Power and the Constitution......... 27

2.1. Constituent Power and Sovereignty .......................................... 29

2.2. Sovereignty, Constituent Power and Democracy................................. 35

3. Different Theories of the People........................................... 40

3.1. The People as Outcome of a Contract....................................... 40

3.2. Homogenous Prior Existence: Scbmittian Decisionism.......................... 44

3.3. Positivist Conceptions of the People .......................................... 47

4.3. A Reflexive "We the People" ............................................ 50

4. The People in Plurinational States....................................... 52

4.1. The People in Multinational States........................................ 53

4.2. The People in Settler-Colonial Contexts................................... 55

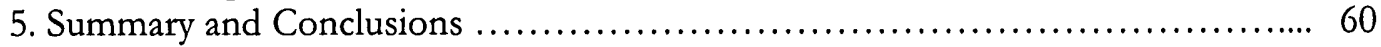

\section{Chapter II}

A Jewish and Democratic State: Theoretical Justifications and Critiques.......... 62

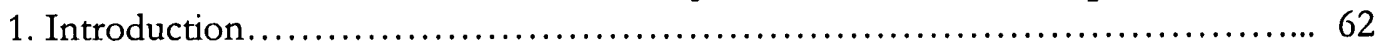

2. Ultra-Nationalist Approaches........................................... 64

3. The Nationalist Approach.............................................. 67

3.1. Conceptual Justification........................................... 67

3.2. Resolving the Tension................................................ 70

3.3. Human Rights, Equality and the Ethnic State............................ 75

3.4. Conclusion......................................................... 80

4. The Pragmatic Approach............................................... 83

4.1. Etbnic Democracy ................................................ 83

4.2. Interpretation and Abstraction: Abaron Barak.............................. 86

4.2.1. Reconciling the Jewish and Democratic Elements......................... 89

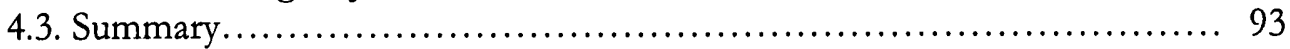

5. The Liberal Approaches.............................................. 94 
5.1. Classic Liberalism....................................................... 94

5.2. Liberal Nationalism..................................................... 97

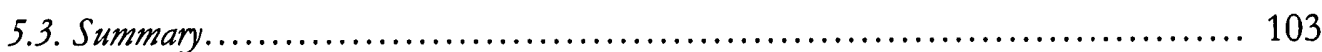

6. Critical Approaches................................................... 106

7. Conclusions.......................................................... 117

\section{Chapter III}

Locating the People in Israel: The Social Contract, the Basic Norm, and the Beginnings of the State.........................................................

1. Introduction

2. The People in Israel Between Theory and Practice: Social Contract, Basic Norm and Nation.

2.1. The Social Contract Theory in Israel...................................... 122

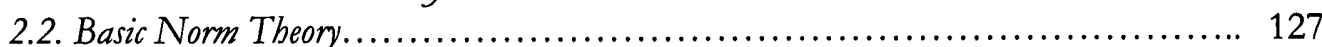

2.3. Israeli Nation v. Israeli People? ................................................ 128

3. Beginnings: The Declaration of Independence............................ 130

3.1. "We Hereby Declare" ................................................... 132

3.2. The Legal Status of the Declaration........................................ 138

3.3. The Declaration and the Prospects of Constitutional Change.......................... 143

4. Summary and Conclusions............................................... 147

\section{Chapter IV}

Engineering the People: Israel's Immigration and Citizenship Laws and

1. Introduction: Immigration, Citizenship and the Numbers Game.

2. First Years (1948-1952)

2.2. The Regulation of Citizenship and Residency 1948-1952.

3. The Law of Return: Jews-only Immigration Policy.

3.1. The Law of Return as a Foundational Element of the Jewish State.................. 165

3.2. "Who is a Jew?" as a Constitutional Question................................... 169

3.3. The Law of Return and the People...................................... 173

4. The Citizenship Law: Citizenship as a Category of Exclusion................... 177

4.1. Acquisition of Citizenship According to Habitual Residence after the Creation of the

4.2. Family Reunification.

4.2.1. Family Reunification and the Court................................. 183

4.2.1.1. The Right to Family Life and the Image of the People.................... 185

4.2.1.2. Comparative Law: Citizens or Residents? .......................... 187

4.3. Loss (and Possible) Reacquisition of Citizenship................................. 189

4.3.1 Ineligibility to Citizenship for Second Generation Descendants Born Outside

Israel...................................................................... 189

4.3.2. Revocation of Citizenship.......................................... 191

4.3.3. Regaining Lost Citizenship.......................................... 193

4.4. The Status of the Palestinians of East Jerusalem............................... 195 
4.5. Summary .......................................................... 196

5. Demography and Equality............................................... 197

5.1. Demography as the Cormerstone of Israeli Policy................................... 197

5.2. Demography and the Supreme Court....................................... 200

5.3. The People Between Demography and Democracy.............................. 204

6. Summary and Conclusions................................................... 208

\section{Chapter V}

Drawing the Red Lines: Political Representation and the Jewish and

Democratic Definition................................................................ 214

1. Introduction........................................................... 214

2. The Evolution of a System of Exclusion: From Yerdor to Section 7A of Basic

Law: The Knesset.............................................................. 216

2.1. Political Representation of the Palestinian Citizens in Israel Post-1948............. 218

2.2. The Yerdor Case and the Triumph of Zionism over Formalism.................... 222

2.3. The Yerdor Case as a Foundational Principle in Israeli Constitutional Law........... 226

3. The Introduction of Section 7A of Basic Law: The Knesset and the

Inperpetration of "Jewish and Democratic" State................................ 228

3.1. Ben Shalom v. CEC ................................................... 230

3.2. The "State of All its Citizens" and Section 7A............................... 234

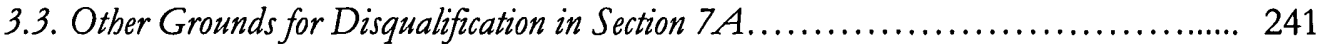

3.4. The Parties Law 1992 ........................................................... 243

4. Debating Section 7A: Who is the People of the Defensive Democracy? ............ 244

4.1. What does Defensive Democracy Defend Exactly? ................................ 244

4.2. Section $7 A$ and the People ...................................................... 252

5. The Jewish and Democratic Definition and the Elected Representatives............ 258

6. Summary and Conclusions.................................................. 262

\section{Chapter VI}

The Constitution in Action: Constitutional Amendments, Law, and Governance 265

1. Introduction.......................................................... 265

2. The Jewish and Democratic Definition in the Process of Constitution-Making.... 266

2.1. The Basic Laws and their Status: The Constitutional Revolution ..................... 267

2.2. The Basic Laws and the Definition of the State.............................. 276

2.3. The Basic Laws and the People............................................. 278

2.4. Constitutional Amendments and the Definition of the State....................... 283

3. Making Law: The Jewish and Democratic Definition of the State and Legislation 289

3.1. Making Law: The Knesset's Rules of Procedure................................... 289

3.2. Interpreting Law: The Jewish and Democratic Values and Statutory Interpretation..... 294

3.3. Challenging Law: Judicial Review of Legislation and the Jewish and Democratic

Definition................................................................ 297

4. The Jewish and Democratic Definition in Other Legislation.................. 304

5. Conclusions and Summary ............................................ 306 
Conclusions

Moving Beyond Exclusionary Constitutionalism............................ 308

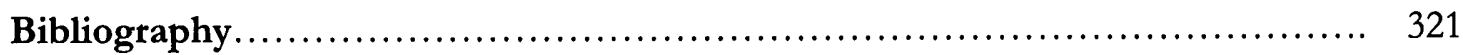

Appendices........................................................ 354

Appendix A: The Declaration of the Establishment of the State of Israel........... 354

Appendix B: The Law of Return- 1950 ................................... 357

Appendix C: Basic Law: Human Dignity and Freedom......................... 359

Appendix D: Basic Law: Freedom of Occupation............................ 361 


\section{List of Abbreviations}

CA Civil Appeal- appeals in civil matters

CEC Central Elections Committee

CLA Civil Leave For Appeal- leave for appeal in civil matters

CrimA Criminal Appeal- appeals in criminal matters

CrimVR Criminal Various Requests- criminal motions

EA Elections Appeal

EC Elections Confirmation

FH Further Hearing- a second hearing at the Supreme Court after an appeal has already been decided

HCJ High Court of Justice- the Supreme Court sitting as a court for constitutional and administrative matters

HP

Hamratsat Ptiba- a simplified civil action

IstSC Supreme Court of Israel

NDA National Democratic Assembly Party 


\section{Introduction}

Atir- Um Al-Heiran is a village in the Naqab (Negev) in the south of Israel. It is the home of the 1,000 members of the Abu Al-Qi'an Bedouin tribe. It has been so since the Israeli Military Governor ordered them to move to that area in 1957 after they were expelled from their original location in 1948/1949. The village is an "unrecognized village" - a village that exists, where people live, but whose existence the state does not acknowledge. The village does not appear on any official map, and no road signs announce the dirt side-road that leads to it. The village is not connected to the electric grid, the water supply system or a sewage system. Healthcare and education services are a bare minimum. The only official recognition the village receives is in zoning maps as "the area designated for demolition" to make room for what will be the town of Hiran, which is designated as a Jewish town. ${ }^{1}$ As planned, the new town will be built on the current location of Atir-Um Al-Heiran. The rest of the area of the village is designated for forestation. A few kilometers away stands another "unrecognized" village, Al-Araqeeb, with a population of 300 people. In 2010, this village was destroyed, all 45 structures were demolished, and 4,500 olive tress were uprooted. The area was designated for forestation to be carried out by the Jewish National Fund. ${ }^{2}$ The residents of the village rebuilt some tents, huts and ramshackle dwellings, which were subsequently destroyed. As of May

\footnotetext{
1Adalah, "Nomads Against Their Will: The Attempted Expulsion of the Arab Bedouin in the Naqab: The Example of Atir Um Al- Heiran" (Haifa: Adalah, 2011), online: $<$ http://www.adalah.org/eng/publications/Nomads $\% 20$ Against $\% 20$ their $\% 20$ Will $\% 20$ English $\% 20$ pdf $\% 20$ final. $\mathrm{pdf}>$.

${ }^{2}$ Adalah, "From Al-Araqib to Susiya: The Forced Displacement of the Palestinians on Both Sides of the Green Line" (Haifa: Adalah, 2013), online: <http://adalah.org/Public/files/English/Publications/Position Papers/Forced-Displacement-Position-Paper0.5-13.pdf $>$.
} 
2013, Al-Araqeeb has been demolished 50 times. $^{3}$ The residents of these villages are Israeli citizens.

Not very far away from these villages are "individual settlements" or "single family settlements". These are large tracts of land, usually hundreds or thousands of acres, allocated to an individual or a single family for the stated purpose of the development of agriculture and tourism while in reality the main objective is to "protect" state land from use by the Arab population. ${ }^{4}$ These have been allocated to Jewish citizens only, and are connected to the water and electricity networks despite the fact that most of them were built in breach of zoning laws. ${ }^{5}$ Some of the legal defects were retroactively rectified by legislation enacted in $2010 .^{6}$ Like the "unrecognized villages", the residents of these settlements (or ranches) are also Israeli citizens.

On the one hand, the state acts, using law, and through the relevant legal channels that include zoning authorities, courts, and enforcement bodies, to demolish villages and replace them with other (Jewish) towns. On the other hand, law is enacted by the legislature and used by the same zoning bodies, courts and enforcement bodies to justify and legitimize the grant of vast tracts of lands to other citizens. This takes place despite numerous decisions by the Supreme Court declaring that in Israel all citizens are ostensibly equal. "The State of Israel", former Chief Justice Aharon Barak stressed in the Ka'dan ruling, "is a Jewish state in which minorities live, including the Arab minority. Every one who belongs to these minorities enjoys

${ }^{3}$ Twafiq Abdel Fattah, "Al Naqab: Al Araqib was Destroyed for the 50"th Time" (in Arabic) Arab 48 (9 May 2013), online: <http://www.arabs48.com/?mod=articles $\& I D=99632>$ [translated by author].

${ }^{4}$ Hana Hamdan, "Individual Settlement in the Naqab: The Exclusion of the Arab Minority", Adalab Newsletter 10 (February 2005), online: <http://adalah.org/newsletter/eng/feb05/fet.pdf>.

${ }^{5}$ Human Rights Watch, "Off the Map: Land and Housing Rights Violations in Israel's Unrecognized Bedouin Villages" (New York: Human Rights Watch, 2008) at 33-36, online: <http://www.hrw.org/reports/2008/iopt0308/iopt0308webwcover.pdf $>$.

6 The Negev Development Autbority Law (Amendment no.4)- 2010 [translated by author]. 
full equal rights." $\mathrm{He}$ went on to state that "equality of rights between humans in Israel, whatever their religion or national belonging is, is derived from the values of the state as a Jewish and democratic state." ${ }^{, 8}$ How can this stated commitment to democracy and equality be reconciled with the situations described above? How can the law and the institutions that make, adjudicate and enforce it, displace one group of people, grant favorable land rights to others, and still be seen as neutral and impartial and fulfilling the requirements of equality among citizens which is at the heart of democracy?

This quandary is only but one example in the curious case of the Israeli constitutional system in which the state is defined as "Jewish and democratic". On the one hand, the state, loyal to the "democratic" part of the Jewish and democratic definition, has the main markers of democracy. The state has a government that is drawn from an elected parliament. Most civil and political rights are guaranteed by basic laws and other instruments such as Israeli "common law". Election results have always been respected, and power is usually transferred smoothly. The legislative branch supervises the actions of the executive branch, and the judiciary has the power to review the actions of the other two branches. Equality is officially a constitutional right, as expressed in the quote by Barak. External bodies also seem to view these markers favorably. Freedom House classified the country as "free", and gave it the score of 1.5 for freedom, 2 for civil liberties, and 1 - the highest score available - for political rights. ${ }^{9}$ In 2010, Israel was invited to join the Organization for Economic Cooperation and

\footnotetext{
7 HCJ 6698/96 'Adel Ka'dan v. Land Administration of Israel (2000), IsrSC 54 (1) 258 at 282 (in Hebrew) [Ka'dan] [translated by author].

${ }^{8}$ Ibid.

9"Freedom in the World 2013: Israel", online: Freedom House

<http://www.freedomhouse.org/report/freedom-world/2013/israel >.
} 
Development (OECD), an exclusive club of states that are, according to its convention, committed to democracy.

On the other hand, the state adopts many policies that are generally seen as "internal colonialism" where the state acts as the tool of a settler society in conflict with an indigenous population. The state is defined as a Jewish state, which means, among other things, that the state promotes Jewish immigration, Jewish nationalism, Jewish culture and heritage, Jewish settlement, and the existence of a special role for the Jewish organizations such as the Jewish Agency and the Jewish National Fund. ${ }^{10}$ The Supreme Court further asserts that the current definition requires a Jewish majority in Israel, and that Israel must preserve a Jewish majority so as to remain a Jewish state. Discrimination, in many cases as a matter of law and policy, can be identified in almost all aspects of life in Israel. Adalah, a human rights organization dedicated to achieving equal individual and collective rights for Palestinians in Israel, ${ }^{11}$ counts more than 50 Israeli laws that discriminate against the Palestinian citizens of Israel. ${ }^{12}$ The number of laws on this list seems to be constantly on the rise. This legal discrimination permeates the social, economic and political spheres. In almost all conceivable areas including health, education, income, employment, budget allocation, social welfare, and development, the Palestinian citizens fare worse, and in some cases, much worse than the Jewish citizens. ${ }^{13}$

\footnotetext{
${ }^{10} \mathrm{Ka}$ 'dan, supra note 7.
}

11 The focus of this dissertation is Israel's constitutional law and not its policies in the West Bank and Gaza Stripalso known as the Occupied Palestinian Territory (OPT). Therefore, unless otherwise mentioned in the text, "Palestinians", "Arabs", "Palestinian minority" or "Palestinian citizens" will refer to the group of Palestinians who are also Israeli citizens, described by the state "Israeli Arabs". Reference to other groups of Palestinians, such those who live in the OPT, or refugees in the shatat (diaspora) will be explicitly mentioned in the text.

${ }^{12}$ For a database of discriminatory laws in Israel see, "Discriminatory Laws in Israel", online: Adalah <http://adalah.org/eng/Israeli-Discriminatory-Law-Database>.

13 For a good summary of all of these policy area, see Adalah, "The Inequality Report: The Palestinian Arab $\begin{array}{lllll}\text { Minority in } \text { (Haifa: } & \text { Adalah, } & \text { 2011) }\end{array}$ <http://adalah.org/upfiles/2011/Adalah The Inequality Report March 2011.pdf>. 
The Palestinian citizens, who are almost $20 \%$ of the Israeli population, ${ }^{14}$ are significantly underrepresented in all branches of government and the civil service, and public sectors such as universities, ${ }^{15}$ despite legislation that mandates "appropriate representation" of Arabs in the civil service and other aspects of the public sector, such as board membership of government owned companies, and legislation that protects equality in employment in general. ${ }^{16}$

Does the fact that the state is defined as a Jewish and democratic state have anything to do with this outcome? What does this definition mean? How is this definition used to justify certain features of constitutional law in Israel and the constitutional order in general? What does it say about the nature of the regime in Israel? This dissertation will to tackle some of these questions by examining the meaning and implications of Israel's definition by focusing on its relationship to certain aspects of the constitutional regime such as sovereignty, constituent power and the idea of the People.

\section{Social, Political and Historical Context}

Although this thesis is focused on constitutional law, some social, political and historical aspects should be briefly considered in order to provide context for the discussion,

\footnotetext{
14 As of May 2013, the population of Israel was 8 million approximately. The Jewish population was approximately 6 million (75.3\%), while the Arab population was 1.65 million (20.7\%). This figure includes the Palestinians of East Jerusalem and the Syrian population of the Golan Height, both of which are occupied territories, and where the residents are mostly Israeli permanent residents and not citizens, except for individual cases. 318,000 (4\%) are categorized as "Others", who are "non-Arab Christians, members of other religions, and persons not classified by religion." See, Central Bureau of Statistics. Press Release, " $65^{\text {th }}$ Independence DayMore than 8 Million Residents in the State of Israel" (141 April 2013) online: <http://www.cbs.gov.il/reader/newhodaot/hodaa template eng.html?hodaa $=201311097>$.

${ }_{15}$ As of 2011 , only $7.78 \%$ of workers in the civil service were Arab. While this figure is low, it is an improvement on the $5.92 \%$ rate in 2006. See State Service Commission, Appropriate Representation for the Arab Population including the Druze and Circassians: Report for the Year 2011, online: <http://www.civil.service.gov.il/NR/rdonlyres/2FCC4CD2-01DD-4FFB-B2B7-CEB995FE0F9F/0/representation2011.pdf>.

${ }_{16}$ See section 15A of the State Service Law (Appointments)-1959; section 18A1 of the Governmental Companies Law1975; Equal Opportunities in Employment Law- 1988.
} 
as law generally, and constitutional law in particular, is best understood in its context. While several chapters of the dissertation will refer to and chronicle historical events and social and political realities, it is helpful to provide the reader with some broader context at this stage.

Israel was created in May 1948 in the area that was (and for many still is) known as Palestine. The creation of the state was the result of the activities and efforts of the Zionist movement, a political movement that aims at creating a Jewish home in Palestine - Jewish home being used as a prudent alternative for the word "state". Zionism, which was predominantly a European movement influenced by the rise of nationalism in Europe, posited that the "solution" for the "Jewish problem" in Europe was the creation of a Jewish state in Palestine. Although other alternative locations to Palestine were discussed, such as Uganda and the Sinai peninsula, Palestine was not a random choice. It was thought of as the "recreation" and the "re-establishment" of the old Jewish kingdoms in a land that many Jews see as their ancestral homeland.

Since its inception, the Zionist movement tried to achieve its goals by creating alliances with imperial powers of that era. The convergence of interests between the Zionist movement and the British Empire led the latter to adopt the cause of Zionism. This paved the way for the Balfour Declaration of 1917 promising the creation of a Jewish homeland in Palestine at the time when Palestine was not under British control, and when less than $10 \%$ of the population was Jewish. The Balfour Declaration was adopted by the League of Nations, and the creation of a Jewish home became one of the goals of the Mandate over Palestine that was facilitated by the mandatory power, the United Kingdom. While this plan was strongly resisted by the local Palestinian Arab population in various ways that included bouts of violent 
revolts one of which lasted for three years (1936-1939), Jewish immigration to Palestine during the Mandate period increased, in part as a result of the rise to power of the Nazis in Germany and the subsequent war and genocide. In 1947, the United Nations General Assembly recommended partition of Palestine into a Jewish state and an Arab state. The Palestinian Arabs rejected the proposal and war ensued. What started as local clashes after the approval of the Plan in November 1947 developed into a full-fledged war with the (reluctant, disorganized and ill-equipped) participation of six neighboring countries. In May 1948, the organized Jewish community declared the state of Israel, and by the end of the war in 1949, it controlled $78 \%$ of the area of historic Palestine. About $80-85 \%$ of the Palestinians who lived in that area fled or were expelled with only 160,000 remaining in Israel, consisting of about $13 \%$ of the population of the new state. ${ }^{17}$

As a Jewish state, the state associated itself with Jews (in the state and abroad) and adopted Jewish symbols. The governance was essentially a continuation of the old pre-state organized Jewish community in the new form of a state. Members of the Palestinian Arab minority, some of whom were granted citizenship in 1952 and participated in parliamentary elections, were seen as outsiders and a threat to the state. This citizenship was not taken for granted, and it did not guarantee equal treatment. As will be discussed in chapter IV, an examination of the citizenship laws and policies exposes many problems despite the existence of seemingly universal citizenship. From 1948 until 1966, the Palestinian population was placed under a Military Administration that interfered with all aspects of life. Freedom of movement was significantly limited and about $70 \%$ of the land that the Palestinian community

17 Statistical Abstract of Israel 2012 (Jerusalem: Central Bureau of Statistics, 2013) at 87, online: <http://www.cbs.gov.il/shnaton63/st02 01.pdf $>$. Details about the population changes will be discussed in chapter IV. 
owned was confiscated by the state, mostly for the construction of Jewish towns or for military use. This was very significant for the predominantly rural population that relied on agriculture for subsistence and income. Even after the end of the Military Administration, the state's approach to the Palestinian minority did not change significantly. As Ian Lustick explains, results similar to the effect of the Military Administration were achieved using what he calls the system of control. ${ }^{18}$

Since 1948, the state has embarked on the creation of a distinctly uniform Jewish identity out of the myriad identities the Jewish immigrants had. The process of nation-building was therefore focused on the Jewish population that was mostly an immigrant population from different places with different languages, customs and cultures. It did not focus on the population as a whole. The nation which the state, or the nation-state (the term many politicians and academics prefer to use) was associated with was the Jewish nation which was being shaped and produced by the state. Despite the citizenship granted to the members of the Palestinian minority, they were not part of the national ethos. The Palestinian citizens were mostly referred to as "minorities" (reflecting their religious diversity), ${ }^{19}$ and in some cases, as the Arab minority (reflecting their language).

Historically, the Palestinians in Israel are part of the Palestinians who lived in pre-1948 Palestine. In some cases, the Green Line - the border line between the area that became Israel and the area that became the West Bank (currently known also as the Occupied Palestinian Territory (OPT) - cuts some villages in half. In many cases, Palestinians on both sides of the Green Line have strong family ties with each other. Despite being under Israeli jurisdiction

${ }^{18}$ Ian Lustick, Arabs in the Jewish State: Israel's Control of a National Minority (Austin, TX: University of Texas Press, 1980).

19 In 2011, there were 1,354,300 Muslim residents, 155,000 Christians (most of them Arab but also include nonArab), and 129,800 Druze. 
and holding Israeli citizenship, most Palestinians in Israel choose to identify as Palestinians in Israel rather than as Israeli. ${ }^{20}$ While the issue of national identity is complex, fluid, and shaped by many different and sometimes contradictory forces and factors, the trend has been an increase in the identification as Palestinian. Nadim Rouhana characterizes the collective identity of the Palestinians in Israel as "an incomplete collective identity in which the Palestinian element satisfied the affective axes of sentimental attachment but not the formal, legal, administrative and everyday instrumentalities, which the Israeli element satisfied, but with no gratification of sentimental needs." ${ }^{21}$ Recent opinion surveys show that a majority of the Palestinian citizens do not feel that Israel is their state on an individual level and collective (Arab) level. A majority rejected the definition of the state as "Jewish and democratic" and preferred to define the state as the state "of all its citizens." About $90 \%$ of the Palestinian minority think that Jews do not have a right to automatically immigrate to Israel while $92 \%$ see Zionism as a racist movement. $83 \%$ of the Palestinian citizens believe that Israel's creation was not just, while $73 \%$ see that at present that state is not just. ${ }^{22}$

These attitudes reflect a sense of deep alienation from the state that is often seen as a colonial state. In addition to discrimination in almost all aspects of life, the state also pursues policies that are described as internal colonialism adding another layer of complexity. Thus, despite the exclusive definition as a Jewish state, or the state of the Jewish people, this definition is in conflict with the multinational or bi-national reality where two national groups live in the same state. While the state affiliates with one group only, and in many areas acts as

\footnotetext{
${ }^{20}$ Nadim N. Rouhana, Palestinian Citizens in an Ethnic Jewish State: Identities in Conflict (New Haven: Yale University Press, 1997) at 8.

21 Ibid at 201.

${ }^{22}$ Nadim N. Rouhana, ed, Attitudes of Palestinians in Israel on Key Political and Social Issues: Survey Research Results, (Haifa: Mada al Carmel, 2007) ch4 online: <http://mada-research.org/en/files/2007/09/ch3.pdf>.
} 
its promoter, it grants official and nominally equal citizenship to the $20 \%$ of its citizens who are Palestinian without recognizing them as a national minority.

\section{Israel as a Jewish and Democratic State}

The idea of a Jewish and democratic state combines two concepts that are extremely rich theoretically, conceptually and empirically. Debates on what democracy and Judaism are, and the question of who is a Jew, seem to be unending. Discussions on the combination of Jewish and democratic are even more complicated. On one hand, a democratic state is understood to be one that is based on the idea of equal citizenship, an inclusive attribute that guarantees equal membership to all members of the polity included in the state, and acceptance of difference. It usually implies a state whose legitimacy is based on the consent of the governed. On the other hand, the concept of a Jewish state is a more ambiguous idea that could carry a number of meanings depending on the different approaches to Jewishness ${ }^{23}$ and the context of the territory and population of this state. In the context of a significant indigenous non-Jewish population, the definition of the state as Jewish may carry the risk of exclusion on the basis of religion and/or ethnicity. Other risks include homogenization by designing the polity along religious and ethnic lines, as well as a problematic role for religion in shaping the state. Prima facie, the Jewish and democratic elements of the state are at odds, or at least in tension, with each other, one promising inclusion and the other implying exclusion. A simple reading of the terms "Jewish and democratic" entails, therefore, an inherent tension if not contradiction and conflict. Yet, the Israeli parliament (Knesset) chose these two words as

\footnotetext{
${ }^{23}$ Some may view Jewishness or Judaism as a purely religious idea. Others may view it as a national or ethnic idea, or a combination of the three conceptions. Some may conceive of it as a matter of culture. Others may think of it as a set of moral guidelines in the spirit of universal and humanist teachings.
} 
the constitutional definition of the state with the enactment of the Basic Law: Human Dignity in 1992.

The idea of the Jewish state found its first explicit expression in written law in 1985 when the Knesset amended Basic Law: The Knesset adding a section that prohibits parties that "negate the existence of Israel as the State of the Jewish people" from participating in the elections. ${ }^{24}$ This relatively late articulation of the character of the state in a basic law does not mean that it only took root in 1985 . On the contrary, the idea that Israel is a Jewish state was so axiomatic and taken for granted that there was no need to declare it in any law or basic law. After all, Israel is the product of the Zionist movement whose goal, as articulated in the First Zionist Conference of 1897, is "the creation of a home for the Jewish people in Palestine to be secured by public law", ${ }^{25}$ and the Declaration on the Establishment of the State of Israel declared "the creation of a Jewish state in Eretz Yisrael (land of Israel) to be known as the State of Israel." ${ }^{26}$ Even before the explicit positive written expression of this idea in laws or basic laws, the Supreme Court used it as a guiding principle in deciding some cases, as will be discussed in chapter III, through references to the Declaration of the Establishment of the state or laws such as the Law of Return. As a political term, the idea of the Jewish state, its meaning, and the ways to realize it go back to the mid nineteenth century if not earlier. ${ }^{27}$

The enactment of the two basic laws Basic Law: Human Dignity and Freedom and Basic Law: Freedom of Occupation, which include the Jewish and democratic definition, and the

\footnotetext{
${ }^{24}$ Section 7A of Basic Law: The Knesset, as amended in 1985. It was later changed to Jewish and democratic.

${ }^{25}$ David Vital, The Origins of Zionism (Oxford: Oxford University Press, 1980) at 368.

${ }^{26}$ The Declaration can be found as Appendix " $A$ ".

${ }^{27}$ Moses Hess, Rome and Jerusalem: A Study in Jewish Nationalism (New York: Bloch Publishing Company, 1945). This book was first published in 1862; Theodor Herzl, The Jewish State: An Attempt at a Modern Solution of the Jewish Question (London: Henry Pordes, 1993). This book was first published in 1896. Although the title of Herzl's book is usually translated as "The Jewish State", the accurate translation from German is the "Jews' State"; See generally, Ben Halpern, The Idea of the Jewish State, 2d ed (Cambridge, MA: Harvard University Press, 1969).
} 
subsequent decision of the Supreme Court of Israel affirming the constitutional nature of those basic laws and their superiority over "regular legislation", put these two terms at the centre stage of Israel's constitutional politics. Their meaning and interpretation became an essential element in the allocation of human rights and constitutional protection and the shaping of Israeli law and policy generally. ${ }^{28}$ The debates on how to interpret the definition are exercises in exploring the meanings of two complex ideas, and the tension that inheres in combining them. The adoption of "Jewish and democratic" as a constitutional definition which has widespread acceptance among Jewish Israeli citizens - creates tensions on at least three levels. The first one is on the national level - the contradiction between the inclusiveness of democracy and the potential exclusion by the nation defined in an ethno/religious manner. This level could be divided into two sub-levels, the symbolic - dealing mainly with questions such as what does it mean that the state and its symbols exclude the non-Jewish and predominantly Palestinian minority - and the material level which focuses on the impact on the allocation of political power and rights in practice. The second level is the religious level the tension between Jewish theology implicit in the term "Jewish" and democracy which tends to limit the role of religion. The third level is territorial, relating to the geographical reach of the Jewish state, and which includes the debate over the status and relationship of Israel to the Occupied Palestinian Territory (OPT).

This dissertation is a contribution to the debates on the meaning of the Jewish and democratic definition on the national level tackling the tensions between the universal/neutral/inclusionary democratic element and the particular/exclusionary/ Jewish element. I will focus more on the practical or material implications of the definition and less

${ }^{28}$ CA 6821/93 Bank Misqrabi HaMe'ouba v. Migdal Kfar Sbitofui (1995), IsrSC 49 (2) 221 (in Hebrew). 
on the cultural or symbolic aspects such as the flag, the anthem and language rights. This does not mean that the cultural and symbolic aspects are unimportant. But in some sense, although they are important and have a significant impact, they are symbols of more deeply embedded and multifaceted understanding of the constitutional order as a Jewish state. I am more interested in the way these understandings are embedded in the constitutional order and how they affect the operation of constitutional law. To this end, I will focus on the material implications of the definition and how it affects the internal ordering of the state, the operation of the law, and the different ways that law affects the life of the citizens as individuals and as collectives. My aim is to explore how the Jewish and democratic definition is entrenched, maintained and constantly regenerated within the constitutional order. In this sense, I view the definition not just as a textual expression in basic laws, legislation or court decisions, but also as the embodiment and representation of an ideology that informs the mindset, policies, and practices in the laws and institutions of the state.

This dissertation is a study of Israeli constitutional law and constitutionalism. Constitutionalism is not easy to define. It is "one of those concepts, evocative and persuasive in its connotations, yet cloudy in its analytic and descriptive content, which at once enrich and confuse political discourse." ${ }^{39}$ While the most widespread articulation of constitutionalism recognizes that constitutions should limit government and uphold the rule of law, there are many other understandings of the idea. Some distinguish between modern and ancient constitutionalism, ${ }^{30}$ others between liberal and republican constitutionalism, ${ }^{31}$ and still others

${ }^{29}$ Thomas C. Grey, "Constitutionalism: An Analytical Framework” in J. Roland. Pennock \& John W. Chapman, eds, Constitutionalism: Nomos XX (New York: New York University Press, 1979) 189 at 189.

${ }^{30}$ See e.g. Charles Howard McIlwain, Constitutionalism: Ancient and Modern (Ithaca, NY: Cornell University Press, 1947). 
between legal and political constitutionalism. ${ }^{32}$ Given the cloudiness of the concept, coming up with a definition is not simple, but one can highlight a number of points that some theorists make. One of them is that constitutions and constitutionalism are not only about limiting government. Before government is limited it should be established according to a constitution, which sets the rules for how public power is exercised, and the relationship between different organs of the state. ${ }^{33}$ These are the aspects that this dissertation will examine: the operation of the constitution in generating, exercising and limiting political power, and will do so through the prism of the People. ${ }^{34}$

Based on constitutional theories that ground the democratic legitimacy of a constitutional order on the idea that the People governs itself through the exercise of popular sovereignty, this dissertation will examine Israel's democracy by asking the question "who is the People in Israel?". The idea of the People has an important and foundational role in a constitutional order. Modern ideas of constitutionalism locate the People as underpinning the constitutional order. The People is the entity that created the constitutional order; the authorship of the constitution is attributed to it, and the power of the state - usually exercised through law - is usually seen as derived from the political power of the People. Given the centrality of the People, the question of who is the People is of utmost importance. The

\footnotetext{
${ }^{31}$ See e.g. Martin Loughlin, "What is Constitutionalisation" in Martin Loughlin \& Petra Dobner, eds, The Twilight of Constitutionalism (Oxford: Oxford University Press, 2010) 47.

32 See e.g. Richard Bellamy, Political Constitutionalism: $A$ Republican Defence of the Constitutionality of Democracy (Cambridge: Cambridge University Press, 2007).

33 See e.g. Loughlin, supra note 31; Jeremy Webber, "Democratic Decision Making as the First Principle of Contemporary Constitutionalism" in Richard Bauman \& Tsvi Kahana, eds, The Least Examined Branch: The Role of Legislatures in the Constitutional State (Cambridge: Cambridge University Press, 2006) 411.

34I use the word People (People with an upper case "P") to refer to the political concept of the political community within a state that is thought of to be the source of political power; People as the demos. I refer to it in singular form and use the upper case to distinguish it from people in common usage as an unspecified group of humans. In Hebrew, "People" would be 'aam (עם), while "people" would be anasheem (אנשים).
} 
People in this context is the "self" in the exercise of self-governance which is one of the most basic ideas in democracy.

One approach is to see the People as the collective of citizens - those who play a role in governing the state through democracy. The citizenry here is the People. The Jewish and democratic definition complicates this question when it comes to Israel especially since $20 \%$ of the population (about $17 \%$ of the citizens) are Palestinian, in addition to about $5 \%$ who are not identified as Jewish. One of the meanings of this definition, as stated by the Supreme Court, is that Israel is the state (and in some variations, the nation-state) of the Jewish people. The Supreme Court and academics such as Amnon Rubenstein, at the same time, see the People, which is also the sovereign in Israel, as the collective of citizens. But on many other occasions, the Supreme Court indicated, and sometimes clearly stated, that sovereignty in Israel is "Jewish sovereignty". ${ }^{35}$ The idea of who is the People in Israel, and by extension, who has sovereignty, is at best ambiguous.

In this dissertation I will suggest a different way of examining who the People is, and who holds sovereignty. By doing so I provide a new approach to the Jewish and democratic definition, its meaning and implications, and its role, modes of operation, maintenance and regeneration within the constitutional regime. Guided by insights from constitutional theories that link the People (who hold sovereignty and constituent power) to the constitution, I examine who is included in the People through the prism of the existing constitutional order, rather than posit that the People in Israel is the citizenry as a whole. An examination of the different facets of the constitutional regime focusing on how political power is generated from the People and exercised by the state and its organs can help identify the source of ultimate 
political power that exercises sovereignty and holds constituent power, and thus who the People is.

In this dissertation, I suggest that the Jewish and democratic definition - despite the right of the Palestinian citizens to vote and other civil and political rights - means, in theory and practice, that in the Israeli constitutional order sovereignty and constituent power are concentrated in the hands of the Jewish citizens (and in some cases non-citizens). This is the hypothesis that I put forward and will explore and seek to defend in this dissertation. The people in this sense does not include all of the citizens. Given the centrality of the People and given the embededness of the Jewish and democratic definition in the constitutional order, this finding has serious implications for democracy and the extent to which Israel can truly be seen as a democracy.

\section{Outline of the Dissertation}

The inquiry into who is included in the People in Israel - and by extension, into who holds sovereignty and constituent power - will explore different questions and dimensions spanning six chapters. The People, and the dynamics of inclusion in and exclusion from it will be the common thread that runs through the six chapters.

Chapter I will explore some questions of constitutional theory. It will examine theoretical perspectives related to sovereignty, constituent power and constitutionalism, and the relationship between these ideas and democracy. The People as a constitutional concept will be explored, highlighting how different theories and theorists conceive of the idea. Here, I will examine ideas and theories such as social contract theories, positivism, and how the 
People in plurinational states could be conceived. The way settler colonialism affects the idea of the people will also be assessed.

After reviewing these general theoretical perspectives in chapter I, chapter II will home in on the question of the Jewish and democratic definition. Here I will review the academic literature on the topic, and classify the different approaches to the Jewish and democratic definition, and the different ways these approaches view the idea of the People. While in many cases the concept of the People is not directly addressed by the different writers, one can discern trends in the different ways the Jewish and democratic definition and the tension inherent in it are approached.

After reviewing the general theoretical literature and the more specific writing on the Jewish and democratic definition, the exploration of "who is the People?" through the prism of the constitutional forms will begin in chapter III. The chapter will open with a focus on the idea of the social contract and the grundnorm - two theories that are put forward by the Supreme Court as underpinning the constitutional order in Israel. An assessment of the constitutional beginnings will follow. Here, I will focus on the first foundational constitutional document, the Declaration of the Establishment of the State of Israel. The examination will combine a close textual interpretation with an examination of the role that the Declaration plays in the constitutional edifice. This chapter will provide indications regarding who the People is in terms of constitutional beginnings.

The People, of course, is not a natural body. It is made and unmade by different social and political actors and institutions reflecting various interests and forces that shape and influence the operation of the constitution and the law. Important factors that contribute to 
shaping the People are citizenship and immigration laws and policies, which will be discussed in chapter IV. These play an important role in shaping the political community, its composition, and image, and, by extension, in determining the contours of the People and how it is conceived.

After examining how the immigration and citizenship laws and policies engineer the People, the focus will turn to the idea of representation in chapter V. Representation is important in shaping the relationship between the governors and the governed. The power of the government (the state writ large) is legitimated through representation. It is one of the ways in which the power of the People is harnessed to be exercised as the political authority of the state. An examination of representation in Israel provides important insights into who the People is. The discussion here will focus on section 7A of Basic Law: The Knesset and other associated pieces of legislation which set recognition of the Jewish and democratic definition of the state as a condition for participation in parliamentary and local elections, and registration of political parties. The way the definition of the state affects the political activities of the elected members will also be discussed.

While representation is the way political power is generated from the People, this power is exercised by the state through legislation and executive power that are governed by the constitution. An examination of the ways the constitution is shaped and amended, and how legislation is enacted, interpreted and reviewed by courts is in essence an examination of the constitution in action. This will be the main theme of chapter VI, where the role of the Jewish and democratic definition will be examined on the various levels of constitutionmaking and law-making in order to assess who is included in the People when it comes to 
these processes.

The final chapter will summarize the findings and provide some concluding remarks. It will demonstrate that while the trend is to accord a measure of nominal inclusion in the People to the Palestinian minority, this inclusion is just nominal. More material and effective are the dynamics of exclusion of Palestinians from the People. This exclusion encompasses all levels of the constitutional order, including in areas where the Jewish and democratic definition is not specifically mentioned. This exclusion is felt in the daily life of the Palestinian citizens. The courts, mainstream academics, politicians and others who shape public opinion often justify, gloss over or dismiss the significance of these dynamics of exclusion using the Jewish and democratic definition. This of course, raises many questions about the nature of democracy of this system and state.

\section{Distinctive Contribution to the Literature}

The body of literature on Israel's definition as a Jewish and democratic state is significant and diverse. The definition has been debated at length in the academic literature and court decisions since the terms were introduced in Basic Law: Human Dignity and Freedom. This literature will be reviewed and categorized in chapter II based on how the different authors approach this definition and engage with it. In this dissertation, I situate myself in what I call the "critical approaches" category, which includes most writers who have pointed out the flaws in the definition and its impact on human rights and democracy. I build on the work of writers in this category, develop some of the themes they present, and at the same time engage the work of writers from the other four categories and court decisions. This 
dissertation seeks to contribute to the existing literature in three ways.

First, the dissertation is an in-depth study on the question of the definition based on constitutional theory, while building on and borrowing from studies from other disciplines, making the study socio-legal in nature rather than purely legal. In this regard, I introduce and discuss some ideas that have received very little attention in the existing debates, such as constituent power, sovereignty (in its internal sense) and the concept of the People as a constituent element of constitutional regimes. Some writers such as Hassan Jabareen and Raef Zreik used constitutional theory in their work and provided remarkable analytical and critical contributions to the literature. ${ }^{36}$ But most of their contributions have come in the form of short pieces many of which are focused on particular areas such as immigration. This dissertation uses and applies constitutional theory to provide a broader and more thorough evaluation of Israeli democracy.

Second, the dissertation is unique in that it provides a more comprehensive and multifaceted analysis of the ways the definition is used in the exclusion of the Palestinian citizens from political power. In one sense, the generation of political power from the People, and its transformation into the political authority of the state through the constitution, legislation and state institutions could be seen as a cycle. The dissertation offers a critical analysis of the deployment and embeddedness of the definition at the different junctures of this cycle. This distinguishes the dissertation from most of the literature, which focuses on specific fields such as immigration, political participation, or legislation and judicial review. I

${ }^{36}$ Hassan Jabareen, "The Constitutional Conception of the 'Jewish and Democratic' State" in Honaida Ghanim \& Antwane Shalhat, eds, The Meaning of a Jewish State (in Arabic) (Ramallah: MADAR The Palestinian Forum for Israeli Studies, 2011) 33; Raef Zreik, "The Persistence of the Exception: Some Remarks on the Story of Israeli Constitutionalism" in Ronit Lentin, ed, Thinking Palestine (London: Zed Books, 2008) 131; Raef Zreik, "Notes on the Value of Theory: Readings in the Law of Return- A Polemic", online: (2008) 2:1 Law and Ethics of Human Rights 13 < http://www.degruyter.com/view/j/lehr>. 
build on the existing literature to produce a combination of in-depth analysis of discrete areas related to the constitutional order, while at the same time I take a step backwards and situate these discrete areas in the broader mosaic of the constitutional order in its entirety. This way, I demonstrate how the constitutional order (with all of the values, actors, institutions, contradictions, tensions) operates to produce and regenerate the dynamics of exclusionary constitutionalism. Furthermore, in discrete areas such as constitutional beginnings, immigration policies, constitutional amendments, in addition to engagement with the existing literature, I also elaborate and develop new ideas that are specific to those areas.

The third contribution is the introduction of settler colonialism or internal colonialism as a tool of analysis that is helpful for understanding the development and the operation of the constitutional order. The framework of settler colonialism as a way to analyze the IsraeliArab conflict has been gaining ground in the past two decades. ${ }^{37}$ This framework has been used by many academics in a number of disciplines. Jurists, however, are lagging behind in incorporating some of the insights of this framework into their work. In this dissertation, I incorporate an analysis of colonialism that helps us understand some of the existing legal arrangements and the reasoning behind them. Here, I find ideas discussed by scholars of colonialism such as "the logic of elimination" and the "dynamics of difference" to be helpful.

In addition to these three areas, I also hope that this study will contribute to further highlighting the relevance of the concept of the People and its relationship with democracy.

\footnotetext{
${ }^{37}$ See chapter I for an analysis of this question and its applicability to the situation in Israel.
} 


\section{Chapter I}

\section{The People and their Constitution: Theoretical Approaches to Constitutionalism, Democracy and Sovereignty}

\section{Introduction}

Much of the literature on Israel's definition as a Jewish and democratic state seeks to establish the democratic character by demonstrating the existence of basic democratic features. The most important features mentioned are elections, the right to vote, and the right to hold office. In addition, other associated rights, mostly civil and political rights, and other features such as the rule of law, the independence of the judiciary and the freedom of press are assessed. ${ }^{1}$ Elections, presented as the main feature of democracy, are seen as the way the people exercises its right to govern itself fulfilling the maxim of the rule of the people by the people. Self-government, or government of the people by the people, is often held as the essence of democracy. ${ }^{2}$

Most of the features mentioned in the previous paragraph are measured in the context of governance. Discussions of democracy in this respect presuppose a state. The legal order which includes norms and institutions is the essence of the state. States, or at least democratic ones, usually base their legitimacy on the consent and the acceptance of the People. States are

\footnotetext{
${ }^{1}$ See e.g. Alan Dowty, "Is Israel Democratic? Substance and Semantic in the 'Ethnic Democracy' Debate" (1999) 4:2 Israel Studies 1. See generally The Israel Democracy Institute, "The Israeli Democracy Index 2011" Jerusalem: The Israel Democracy Institute, 2011) online: http://www.idi.org.il/sites/english/events/ThePresidentsConference/Documents/Democracy $\% 20 I n d e x \% 2020$ 11.pdf

2 See e.g. Frank I. Michelman, "Brennan and Democracy: The 1996-97 Brennan Center Symposium Lecture" (1998) 86:3 California Law Review 399.
} 
even often presented as the creation of the People. The constitution, situated at the top of the hierarchy of the legal order, is often regarded by theories of constitutional law as representative of the will of the People who, through the constitution, create the norms and institutions that shape the legal order. In Thomas Paine's words, "[a] constitution is a thing antecedent to a government, and a government is only the creature of a constitution." 3 Thus, governmental power is generated by the consent of the people through the constitution. To use Paine's words again, "the individuals themselves, each in his own personal and sovereign right, entered into a compact with each other to produce a government: and this is the only mode in which governments have a right to arise, and the only principle on which they have a right to exist". ${ }^{4}$ Modern constitutions attain their higher normative level because they are seen as a contract amongst the People to establish, and also to limit, the powers of the institutions of the state. The People, often thought of as "the authors" of the constitution, or as those who consented to it, agreed to give the state the authority to establish and maintain the legal order. As the representation of the collective will, the constitution gains its higher status and authority to bind the constituted institutions and the People who agreed to it. It comes as no surprise, therefore, that many constitutions around the world contain a clause in the preamble attributing the constitution to the People. ${ }^{5}$

The People as such, however, exercise very little power in the state, if at all. The powers of the state, as governed by the constitution, are exercised by its different branches leaving very little power in the hands of those who constituted it. This situation, where the People has the power to constitute the legal order, and then become subject to the constituted

\footnotetext{
${ }^{3}$ Thomas Paine, Common Sense and Other Writings, by J.M. Opal (London: W.W. Norton \& Company, 2012) at 69. ${ }^{4}$ Ibid at 68.

5 See e.g. the US, Indian and South African Constitutions which begin with the words "We the people". See also, Article 3 of the French Constitution of October 4, 1958.
} 
form which exercises power over the people, has been described as the "paradox of constitutionalism". "This paradox also leads to another question: who is the People? How does the People come to possess the power to make the constitution? What is the relationship between the People, the power to make a constitution, and democracy?

Since modern constitutional theory views the People that exercises its sovereignty as a central component of the constitutional order, the question of "who is the People?" should be discussed in order to locate the source of political authority. The question of "who is the People?" goes to the core of the democratic legitimacy of the state, especially one that is defined normatively in ethno-religious terms. In other words, in order to assess democracy in a given constitutional order, one should start with the question of who is included in the People, in order to examine who is included in the "self" of self-governance. Bearing this question in mind, this chapter will provide the theoretical frameworks which will inform the discussion on the meaning of Israel's definition as a Jewish and democratic state in the following chapters. Here, I will provide an overview of the relevant theories related to constitutionalism, peoplehood, and constitution-making.

As a matter of constitutional theory, the question of who is the People is not simple, and different theories provide different formulations. In practice however, in most states, the People is usually seen as the collective of citizens who live in the area of the state and have the right to vote - the electorate. Though it is a rather restrictive understanding, ${ }^{7}$ it seems to be

\footnotetext{
"Martin Loughlin \& Neil Walker, "Introduction" in Martin Loughlin \& Neil Walker, eds, The Paradox of Constitutionalism: Constituent Power and Constitutional Form (Oxford: Oxford University Press, 2007) at 1.

7 This is a rather restrictive category and to some extent arbitrary since citizenship itself is constructed by law. This has led some to adopt different criteria for inclusion in the "people", such as living in a particular territory as advocated by Fredrick Douglas in the context of slavery and the US Constitution. See Fredrick Douglas, "The Constitution of the United States: Is it Pro-slavery or Anti-Slavery?", online: TeachingAmericanHisotry.org < http://teachingamericanhistory.org/library/index.asp?document $=1128>$. Douglas said:
} 
common. ${ }^{8}$ In Israel, the state is constitutionally defined as a Jewish and democratic state, or in other variations, the state of the Jewish people. Given this definition, the answer to the question "who is the People?" is not as clear. Is it the citizens? Is it the Jewish citizens? Is it all Jews? The ambiguity regarding these questions, and the many questions that arise from the Jewish and democratic definition, highlight the need to discuss democracy at the constitutional level in order to address some foundational questions prior to the examination of the traditional standards for measuring democracy. Democracy in this sense should be examined at the foundational/constitutional level of the state since structural defects at the foundational level may be replicated and reinforced at the governance level.

The question "who is the People?" or who is included in the People, is not just a purely theoretical question. As will be explained in this chapter, the concept of the People is related to sovereignty and constituent power - the power to make and change the constitutional order. This constitutional order exercises authority over the citizens and organs of the state. Exclusion from the People, in a sense, means lack of control, or lack of "ownership" or "partnership" or influence over the constitutional order. This is likely to translate into discriminatory laws and policies, or, at best, laws and policies that ignore the needs and interests of different parts of the population.

Its [the Constitution's] language is "we the people;" not we the white people, not even we the citizens, not we the privileged class, not we the high, not we the low, but we the people; not we the horses, sheep, and swine, and wheel-barrows, but we the people, we the human inhabitants; and, if Negroes are people, they are included in the benefits for which the Constitution of America was ordained and established.

And of course, there is the important question of the status of expatriates and individuals who do not enjoy citizen status such as long terms residents, but this is beyond the scope of this dissertation.

8 For a critical assessments of the US context, see Linda Bosniak, "Persons and Citizens in Constitutional Thought" (2010) 8:1 International Journal of Constitutional Law 9 at 23. See also Gerald L. Neuman, "Whose Constitution?" (1991) 100:4 Yale Law Journal 909. 
I will start by introducing the concept of constituent power as the basis for the creation of the constitution. I will then discuss the relationship between constituent power, sovereignty and democracy at the constitutional level. Questions related to these concepts arise in various situations in Israel, especially in discussions related to the assumptions underlying the constitutional order and who, or which bodies, can exercise constituent power and what are the restrictions on constituent power. The Jewish definition of the state adds a level of complexity to these questions which will be probed throughout the dissertation. In section three, I will turn to examine the different conceptions of the People posited by political and constitutional theorists. Some of the theories examined here are used the Supreme Court of Israel and some theorists to explain the constitutional evolution of the state, and in some (rare) cases, to decide the outcome of constitutional questions, as will be explained in chapter III. Section four will focus mostly on the idea of the People in multinational states. This discussion is most relevant regarding Israel, given the sociological and political reality where more than one national group live in one state, and given the colonial history and present. The discussion will not be limited to one theoretical approach, but will examine the ways different schools of thought (liberal, republican, critical) approach these topics. The last section will provide a summary of the way these theoretical questions will inform the discussion. It should be highlighted at this stage that the discussion here is focused on theory. The reality is more complicated and many note that the notion that the People is self-governing is diminishing in practice due to many factors. ${ }^{9}$ This highlights the ${ }^{9}$ For many reasons, which include biased electoral laws, concentration of wealth, control of the media, biased
campaign funding regulation, political parties and their flawed structure, and the increase of the influence of
lobbyists, pressure groups and think tanks, many writers observe that the ideas of self-governance and liberal
democracy are being eroded. See e.g. Noam Chomsky, Profit Over People (New York: Seven Stories Press, 1999);
Slavoj Žižek, First as Tragedy, Then as Farce (London: Verso, 2009); Jacob Rowbottom, Democracy Distorted: Wealth, 
need to measure state performance against idealized theories both in practice and theory. While most states will fail in some aspects of practice, in the case of Israel, many questions arise at the level of theory even before examining the state practice.

\section{Beginnings: Political Ordering, Constituent Power and Constitution}

Constituent power, which is the English translation for the French term pouvoir constituant, is the power to make the constitution, and by extension, to dictate fundamental norms of the political and legal order. As Antonio Negri puts it, constituent power "is the power to establish a new juridical arrangement, to regulate juridical relationships within a new community." ${ }^{10}$ Since it is perceived to predate the constitution, that is, to exist before the creation of law and the legal system, it is essentially political in nature rather than juristic, which may explain why jurists are sometimes reluctant to engage it or even tend to suppress it. ${ }^{11}$ Because of its political nature and the power to create and reorder, constituent power is very often related to revolution, as revolution destroys the legal and political order and replaces it with a new one. ${ }^{12}$

Theories of constituent power rely on the distinction between constituted power, generally presented as the constitutional power of the state cast in a formal form (constitution, institutions, law, etc), and constituent power. This distinction, in Martin Loughlin's words, is

Influence and Democratic Politics (Cambridge: Cambridge University Press, 2010). Another reason for the erosion of the role of self-governance is globalization. The state no longer has exclusive control on many of the functions and processes that were previously seen as the state's domain. This has led to the rise of new areas of research such as "global constitutionalism" and "global governance" to theorize the current changes in the relationships between states and international institutions, and the impact of new international regimes on the states and their inhabitants. See generally Antje Wiener et at, "Global Constitutionalism: Human Rights, Democracy and the Rule of Law” (2012) 1:1 Global Constitutionalism 1.

${ }^{10}$ Antonio Negri, Insurgencies: Constituent Power and the Modern State (Minneapolis: University of Minnesota Press, 1999) at 2.

11 Martin Loughlin, The Idea of Public Law (Oxford: Oxford University Press, 2003) at 99 [Loughlin, "The Idea"]

${ }^{12}$ Negri, supra note 10 
the distinction "between the formal and the material, between competence and capacity, between the distributive and the generative, between the legal and the political". ${ }^{13}$ Loughlin situates constituent power in the realm of public law understood as droit politique, ${ }^{14}$ or as he translates it, public law as political right-ordering. ${ }^{15}$ This conception of public law goes beyond positive constitutional law and focuses on the laws, broadly understood, that establish the governmental authority. Constituent power cannot be understood without reference to the constituted power (form of government). There is a reflexive dynamic between the constituent and the constituted, and the constituent continues to affect the constitutional form. ${ }^{16}$ It finds expression mostly when the formal constitution needs maintenance to accommodate to changes.

This distinction between constituent and constituted is very clear in Emmanuel Joseph Sieyès writings, one of the early writers who dealt with the concept of constituent power. Writing in France in June of 1789, Sieyès discussed what he called the "political constitution of society", arguing that in order to create any body, there is a need to give it a constitution: the laws and procedures that would allow the body to fulfill its purpose. ${ }^{17}$ The state constitution, Sieyès argues, is created by a common will which represents the nation. The constitution, in turn, organizes law-making powers and processes as well as the government.

\footnotetext{
${ }^{13}$ Loughlin, "The Idea", supra note 11 at 100.

14 Loughlin, "The Idea", supra note 11 (Loughlin defines public law as extending "beyond a concern with the edicts of the sovereign authority and embraces precepts of right conduct. Public law is neither a code of rules nor a set of principles, but a practice. Understood as the law relating to the activity of governing, public law can be defined as that assemblage of rules, principles, canons, maxims, customs, usages, and manners that condition, sustain, and regulate the activity of governing. These practices comprise conventions and rules of speech-a vocabulary and a syntax - which are being continuously developed." at 155).

15 Martin Loughlin, Foundations of Public Law (Oxford: Oxford University Press, 2010) at 9 [Loughlin, "Foundations"].

16 Ibid at 227.

${ }^{17}$ Emmanuel Joseph Sieyès, What is the Third Estate, translated by M. Blondel (New York and London: Fredrick a. Praeger Publisher, 1963) at 123.
} 
The government (constituted power) is bound by the constitution and acts through the constitution only. The nation on the other hand, which holds the constituent power, "cannot be and it must not be" subject to the constitution. ${ }^{18}$ The nation, Sieyès asserts, "is prior to everything. It is the source of everything. Its will is always legal; indeed it is the law itself. Prior to and above the nation there is only natural law." ${ }^{19}$ It follows that the relationship between the two bodies, the nation and the constitution -constituent power and constituted power - is a relationship of delegation, and as such, "[n]o type of delegated power can in any way alter the conditions of its delegation."20

\subsection{Constituent Power and Sovereignty}

Different strands of the concept of constituent power could be traced back to philosophers as early as Hobbes and Locke. ${ }^{21}$ But prior to the introduction of constituent power to debates on the nature of the state, sovereignty was (and still is) the main enduring concept through which the state and its powers are understood. Since the sixteenth century, sovereignty has emerged as a concept to explain the public power and authority of the state. Although modern sovereignty is usually associated with the Peace of Westphalia of 1648, Jean Bodin identified it, as early as 1576, as "the chief point... in a treatise on the commonwealth." $22 \mathrm{He}$ defines sovereignty as "the absolute and perpetual power of a commonwealth". 23

${ }^{18}$ Ibid at 126 . The nation can bind its members through the constitution, see ibid at 127.

19 Ibid at 124.

20 Ibid at 125.

21 See Murry Forsyth, "Thomas Hobbes and the Constituent Power of the People" (1981) 29 Political Studies 191; Loughlin, “The Idea", supra note 11 at 102-103.

22 Jean Bodin, On Sovereignty: Four Chapters From Six Books of the Commonwealth, translated by Julian H. Franklin (Cambridge: Cambridge University Press, 1992) at 1.

${ }^{23}$ Ibid. 
Today, sovereignty is widely understood as the supreme authority within a territory, ${ }^{24}$ or the ultimate power within that territory. ${ }^{25}$ This definition, however, is ambiguous and leaves room for various conceptions of sovereignty; sovereignty therefore cannot be understood as having one specific meaning. It is best understood as a cluster concept; one that is understood in related but not necessarily identical conceptions. It is also a contested concept since competing theoretical approaches support and promote different conceptions. ${ }^{26}$ Since this could be a source of confusion, it is important to clarify which sense of sovereignty is being discussed in this part.

In the French context, for example, Carré de Malberg distinguished between three meanings of the word "souveraineté", the French equivalent for sovereignty. The first meaning relates to the supreme character of the state. The second meaning encompasses the whole of powers included in the authority of the state, and the third sense relates to the position occupied in the state by the highest holder of the state authority. Sovereignty in the last sense is identified with the authority of the latter. ${ }^{27}$ In addition to these three understandings of sovereignty, Michel Troper adds a fourth one: "the quality of a being in whose name sovereignty in the first three senses is exercised" ${ }^{28}$ In this sense, sovereignty is imputed to an entity called the sovereign which could be the People or the monarch. Neil MacCormick, following Dicey, distinguishes between legal and political sovereignty. The

24The Stanford Encyclopedia of Philosophy (Summer 2010 Edition), "Sovereignty" by Dan Philpott, online: $<$ http://plato.stanford.edu/archives/sum2010/entries/sovereignty>.

25 The Max Planck Encyclopedia of Public International Law, "Sovereignty" by Samantha Besson, online: $<$ www.mpepil.com>.

${ }^{26}$ Neil MacCormick, "Sovereignty and After" in Quentin Skinner \& Hent Kalmo, eds, Sovereignty in Fragments (Cambridge: Cambridge University Press, 2010) 152.

${ }^{27}$ R. Carré de Malberg, Contribution à la Théorie générale de l'État (Paris: Librarie de la sociét du Recueil Sirey, 1920) vol 1 at 79.

${ }^{28}$ Michel Troper, "The Survival of Sovereignty" in Hent Kalmo \& Quentin Skinner, eds, Sovereignty in Fragments: The Past, Present, and Future of a Contested Concept (Cambridge: Cambridge University Press, 2010) 139. 
former is related to law-making power unrestricted by legal limits, and the latter deals with the organ of the state whose will commands the obedience of the citizens. ${ }^{29} \mathrm{He}$ also distinguishes between internal sovereignty, which deals with the ordering of power within the state, and external sovereignty, which means freedom from subordination to any power acting from without. ${ }^{30}$ Given that the emphasis here is on constitutional theory and not international law, the conception of sovereignty that concerns us is the one dealing with the internal authority only.

Because of the formidable and extraordinary power and authority attributed to sovereignty and the holder of this power, sovereignty is often identified with constituent power. Elements of this identification can be traced back to the seventeenth and eighteenth century, as can be seen in the writings of Johannes Althusius, George Lawson, John Locke, James Madison and, more comprehensively, in the work of Sieyès, Thomas Paine and Carl Schmitt. ${ }^{31}$ All of them derived the power to create a legal and political order, or the government (constituted power), from a prior and supreme power. This power is vested in the People, or the nation or the sovereignty of the realm, as Althusius puts it. In all of these articulations, the right of the constituted body to make law is inextricable from the political nature of the act of creating the constituted body.

These developments in the idea of sovereignty, where the juristic conception (authority to make law) is intimately and inextricably related to the political conception led

\footnotetext{
29 Neil MacCormick, Questioning Sovereignty (Oxford: Oxford University Press, 1999) at 127 [MacCormick, "Questioning Sovereignty"].

30 Ibid at 129.

31 Andreas Kalyvas, "Popular Sovereignty, Democracy and the Constituent Power" (2005) 12 Constellations 223 at 226; Joel Colon-Rios, "The Legitimacy of the Juridical: Constituent Power, Democracy and the Limits of Constitutional Reform" (2010) 48 Osgoode Hall Law Journal 199 at 210; Loughlin, "Foundations", supra note 15 at 70-71.
} 
some constitutional law theorists to reject the distinction between the legal and political conception. Contrary to legal positivists who try to place sovereignty in a formal legal frame, Martin Loughlin argues that sovereignty is related to political power which is expressed through law. For him, as for Neil Walker, sovereignty cannot be understood from a purely legal or purely political point of view. ${ }^{32}$ It is "situated at the boundary between politics and law." "33 Sovereignty is therefore best understood "as a representation of the autonomy of the political". "For Loughlin, sovereignty is formed in the process "in which a group of people within a defined territory is moulded into an orderly cohesion through the establishment of a governing authority that can be differentiated from society and which is able to exercise an absolute political power." 35 It is best understood as relational. It is situated in the relationship between the People and the institutional framework of political power. On the one hand, its legal conception (the authority to give law, or its distributive aspect) is expressed in the relationship between the office entrusted to make law and the subjects of this law, on the other hand, its political conception (political power, or the generative aspect) could be located in the capacity of the People, acting together as a unit, to constitute, abolish or change the existing political and legal order. Political sovereignty, thus understood, is synonymous with

\footnotetext{
32 Loughlin, "The Idea", supra note 11 at 73.

${ }^{33}$ Neil Walker, "Disciplinary Perspectives" in Neil Walker, ed, Sovereignty in Transition (Oxford: Hart Publishing, 2003) 20.

34 Loughlin, "The Idea", supra note 11 at 72. It is important to highlight the definition of the concept of "the political" and distinguish it from "politics". Following Carl Shmitt, Loughlin describes the political as the state of antagonism and the ever present possibility of conflict, the persistence of this state and its threats creates political behavior. For Schmitt, the main concern of the political is the distinction between friend and foe. See Loughlin, "The Idea", supra note 11 at 33-24. Chantal Mouffe uses Heidegger's vocabulary to distinguish between the political and politics. She suggests that "politics" refers to the "ontic" level that has to do with practices of conventional politics. The political on the other hand refers to the "ontological" level that deals with the very way society is instituted. See Chantal Mouffe, On the Political (New York: Routledge, 2005) at 8-9.

35 Martin Loughlin, "Ten Tenets of Sovereignty" in Neil Walker, ed, Sovereignty in Transition (Oxford: Hart Publishing, 2003) 56.
} 
Sieyès's constituent power, and rests on the premise that ultimate political power ultimately rests in the People (or the nation for Sieyès). ${ }^{36}$

Writers with liberal inclinations also accept a variation of the idea of popular sovereignty as the source of the legitimacy of the constitutional order and agree that it is exercised by the People. Jeremy Waldron for example places popular sovereignty at the heart of liberal thought stating that it "requires that the people should have whatever constitution, whatever form of government they want." ${ }^{37}$ Bruce Ackerman, discussing US constitutional law, distinguishes between what he calls "constitutional politics" and "normal politics". The latter represent acts of governance by the different branches of the state which are an ongoing daily occurrence. "Constitutional politics" on the other hand occur when "we the people" speak and exercise its popular sovereignty. "Constitutional politics" entail a fundamental change to the constitution through extra-constitutional means. The change is seen to be ratified by a mobilized mass of citizens exercising the popular sovereignty of the People. The People are the highest source of authority. ${ }^{38}$ Akhil Reed Amar is another American constitutional theorist who also makes strong connections between popular sovereignty and the constitution. For Amar, the very idea of republican rule rests on popular sovereignty. Thus he says, "[i]n a Republican Government, the people rule."39 This form of government requires that the constitution be derived from the People and be amenable to alteration by them. Amar concludes that the US Constitution could be amended by the people in ways other than the ones

\footnotetext{
${ }^{36}$ Loughlin, "The Idea", supra note 11 at 67-68, 82-86.

${ }^{37}$ Jeremy Waldron, "Precommitment and Disagreement" in Larry Alexander, ed, Constitutionalism: Philosophical Foundations (Cambridge: Cambridge University Press, 1998) at 272.

38 Bruce Ackerman, "The Storrs Lecture: Discovering the Constitution" (1983-1984) 93 Yale Law Journal 1013; Bruce Ackerman, We the People: Beginnings (Cambridge MA: Cambridge University Press, 1991).

${ }^{39}$ Akhil Reed Amar, "The Central Meaning of Republican Government: Popular Sovereignty, Majority Rule, and the Denominator Problem" (1993-1994) 65 University of Colorado Law Review 749 at 749.
} 
prescribed in the amendment article (Article V) since this article is only binding on the Government and not the People. ${ }^{40}$ Popular sovereignty, which Amar reads as part of the US Constitution, is even seen as higher than the Constitution. While the Constitution is alienable, popular sovereignty, Amar argues, is inalienable. ${ }^{41}$

Though in these accounts of sovereignty there is no mention of constituent power as such, the main idea is that the legitimacy of the constitution is derived from the notion that the People have consented to it. The idea of consent, it should be noted, is ambiguous enough and tolerates a range of conceptions. On the more liberal side, Locke and Kant, for example, did not require actual consent. Tacit consent was enough for Locke, and Kant assumed consent as long as it is rational to consent. ${ }^{42}$ More critical accounts suggest that there may be shortcomings in the various existing theories of consent. ${ }^{43}$ Similarly, critical accounts of the idea of popular sovereignty of the People suggest that historically it may have more to do with benefiting the elites rather than the People. ${ }^{44}$ Still, many modern constitutions today locate sovereignty in the People. ${ }^{45}$

Even though no Israeli constitutional text locates sovereignty in the People, the Supreme Court has stated a number of times that "sovereignty belongs to the People." ${ }^{46}$ Such

\footnotetext{
40 Akhil Reed Amar, "The Consent of the Governed: Constitutional Amendment Outside of Article V" (1994) 94 Columbia Law Review 457.

${ }^{41}$ Ibid at 500.

42 Immanuel Kant, "On the common saying: "This may be true in theory, but it does not apply in practice"' in Hans Reiss, ed, Kant: Political Writings, 2d ed (Cambridge: Cambridge University Press, 1991) at 61-92, 79.

${ }^{43}$ Jeremy Webber, "The Meanings of Consent" in Jeremy Webber \& Colin M. Macleod, eds, Between Consenting People: Political Community and the Meaning of Consent (Vancouver: University of British Columbia Press, 2010) 3.

44 Edmund S. Morgan, Inventing the People: The Rise of Popular Sovereignty in England and America (New York: W.W. Norton \& Company, 1988) at 304.

45 See e.g. Art. 1 of the Constitution of the Italian Republic; art. 3 of the French Constitution. The German Grundgesetz the Basic Law, provides in its preamble that is was adopted by the "German people in their exercise of their constituent power."

${ }^{46}$ CA 6821/93 Bank Mizrabi HaMe'ouba v. Migdal Kfar Sbitofui (1995), IsrSC 49 (2) 221 at 399 [Bank Mizrabr]. See the discussion in chapters III and VI.
} 
statements are usually made in cases that deal with important constitutional questions, such as the constitutional status of the basic laws. These statements, however, are diminished by other statements that relate sovereignty to the Jewish people exclusively. This makes the questions of "who is the sovereign?" and "who is the People?" more complex and thus they require further probing. This will be one of the running themes of the dissertation; the way the Supreme Court has approached the question of sovereignty will be addressed in chapter III.

\subsection{Sovereignty, Constituent Power and Democracy}

Despite some ambiguities about popular sovereignty, many theorists see it as closely related to democracy, to the point that some authors use both terms interchangeably. ${ }^{47}$ Democracy can be seen as encompassing two dimensions. The first dimension, which is the focus of most democrats, is democratic governance which deals with a range of issues related to governance and legislation. The second dimension is democracy at the level of fundamental law. Constituent power, as a concept that explains the creation or replacement of constitutional orders, is closely related to democracy at the foundational stage or at the level of fundamental law. In a democracy, constituent power is premised on the idea that the constitutional order is created by the People exercising popular sovereignty. The very idea that people come together to make the constitution denotes democracy. Antonio Negri, for example, starts his book on constituent power by saying " $[t]$ o speak of constituent power is to speak of democracy." 48 Similarly, Loughlin sees constituent power as the "juristic expression

47 James Tully, "The Unfreedom of the Moderns in Comparison to Their Ideals of Constitutional Democracy" (2002) 65 Modern Law Review 204 at 205. Waldron on the other hand distinguishes between popular sovereignty and democracy, see supra note 37 at 272.

48 Supra note 10 at 1. 
of the democratic impetus." ${ }^{49}$ Constituent power as the representation of the will of the People is one of the manifestations of democracy. If we understand democracy as rule by the People, then constituent power is what creates the framework for making this rule possible. This power, however, can find its expression as a democratic will of the People only through representative forms which entail institutional arrangements. The constitution is thus seen as an institutional framework for organizing and generating political power. ${ }^{50}$

How does democracy play a role at the level of the fundamental laws? How can we measure how democratic the constitution is? Different commentators address this question using a number of frameworks emphasizing different aspects. Some, like Andreas Kalyvas, focus on the democratic origins of the constitution. He notes that the term "to constitute" comes from the Latin word constituere. Constituere is made up of two parts: "con" and "staturere". "Con" means "with" or "together", and "staturere" - which comes from "statuo"- means "to cause to stand", or to set up, to construct, to erect. To constitute, therefore, means "to found together, or to found in concert". What follows is that the act of constitution-making is a collective act of erecting a higher order. ${ }^{51}$ For Kalyvas, constituent power entails popular sovereignty. Since the exercise of constituent power is also an exercise of popular sovereignty, this bestows democratic legitimacy on the product, that is, the constitution. ${ }^{52}$ Hence, a constitution is democratic if it was the result of a genuine act of popular sovereignty/constituent power of the People. The wider the participation in the process is, the more democratic and more legitimate the constitution is. ${ }^{53}$ In a similar vein, based on the

${ }^{49}$ Loughlin, "The Idea", supra note 11 at 100.

${ }^{50}$ Loughlin, "The Idea", supra note 11 at 112-113.

${ }^{51}$ Kalyvas, supra note 31 at 235.

52 Kalyvas, supra note 31 at 237.

${ }^{53}$ Kalyvas, supra note 31 at 238. 
history of constitutionalism, Andrew Arato suggests a number of principles that help achieve democratic legitimacy for a constitution. These include wide public discussion, preference for consensus, legal continuity, and multiple levels of democracy such as constitutional assemblies and referenda. ${ }^{54}$

But what about the democratic legitimacy of the majority of existing constitutions that were not created with wide popular participation? Joel Colón-Rios agrees with the premise that constituent power and democracy are very closely related and that democratic participation in the creation of the constitution is an important indication of the democratic pedigree, but he notes that most constitutions will fail this test. Observing that most constitutions were adopted by political elites excluding the overwhelming majority of the population, he extends the participation standard to the susceptibility to reconstitution. A constitution gains democratic legitimacy if it provides mechanisms that facilitate the exercise of constituent power. ${ }^{55}$ For a constitutional regime to be democratically legitimate, Colón-Rios argues, "it must not mystify, displace, legalize, or hide constituent power; on the contrary, it must provide a real possibility for its exercise." ${ }^{~} 56$ Such a constitution will have the democratic openness that would allow the citizens to effect constitutional change through popular participation. $^{57}$

While liberals also see the democratic legitimacy of a constitution to be based on the political authority of the sovereign People, ${ }^{58}$ the question of constituent power does not arise

\footnotetext{
54 Andrew Arato, "Forms of Constitution Making and Theories of Democracy" (1995-1996) 17 Cardozo Law Review 191 at 224-227.

55 Colón-Rios, supra note 31 at 217.

56 Ibid at 235.

57 Ibid.

58 See e.g. Samuel Freeman, "Constitutional Democracy and the Legitimacy of Judicial Review" (1990) 9:4 Law and Philosophy 327.
} 
frequently in liberal constitutionalism debates. ${ }^{59}$ The main debates on democratic legitimacy either highlight the democratic procedures prescribed by the constitution, or the substantive outcome of its operation. Jeremy Waldron is probably the best representative of the former approach. Waldron emphasizes the democratic procedures for making decisions (legislation for example), highlighting the importance of political participation. ${ }^{60}$ Ronald Dworkin on the other hand is an example for the substantive approach. He has no interest in the democratic authorship of the constitution. ${ }^{61}$ For him, the defining aim of democracy is "that collective decisions be made by political institutions whose structure, composition, and practices treat all members of the community, as individuals, with equal concern and respect.",02

To sum up this section, democracy is relevant at the foundational level of making the constitution. While different approaches highlight different aspects of democracy, still there is agreement that democracy means more than solely holding elections. While some highlight the democratic nature of the constitution-making process, others emphasize democracy at the level of the operation of the constitution. Democracy should be maintained at the level of making the constitution and its operation. Democracy on both levels is seen by different theorists as the realization of popular sovereignty - the sovereignty of the People.

In Israel, questions of constituent power, constitution-making and democratic pedigree of the constitution arise in the context of the two basic laws adopted in the early 1990s. As will be discussed in chapter VI, these two basic laws also included reference to the

${ }^{59}$ David Dyzenhaus, "The Politics of the Question of Constituent Power" in Martin Loughlin \& Neil Walker, eds, The Paradox of Constitutionalism: Constituent Power and Constitutional Form (Oxford: Oxford University Press, 2007) 129.

60 See generally Jeremy Waldron, "A Right-Based Critique of Constitutional Rights" (1993) 13:1 Oxford Journal of Legal Studies 18; Jeremy Waldron, Law and Disagreement (Oxford: Oxford University Press, 1999).

${ }^{61}$ Michelman, supra note 2 at 411.

${ }^{62}$ Ronald Dworkin, Freedom's Law: The Moral Reading of the American Constitution (Oxford: Oxford University Press, 1996) at 17. 
definition of the state as a Jewish and democratic state. The democratic legitimacy of the basic laws was challenged based on the principles and ideas reviewed in this section related to participation and public discussion and consensus. Another pertinent issue is the way the idea of constituent power is used in the Israeli context. In some sense, as will be elaborated in chapter VI, it is reduced to a technical term devoid of its democratic potential, and rather than attributing it to the People, it is given to the Knesset, making constituent power part of the constituted body. On the level of the operation of the constitution, a number of questions arise in the context of political participation and legislation in Israel. A number of laws, basic laws and other legal instruments impose restrictions on democratic participation and the process of legislation. These restrictions are based on the state's definition as a Jewish and democratic state. Those aspects will be discussed in chapters V and VI.

The concepts discussed thus far keep referring to the People. This term is one of the main referents in discussions on political authority. Even during early modernity, when divine authority was seen as a source of authority, the People still enjoyed a relevant status. Scholastics of the sixteenth century, for example, explained that the power of the ruler emanates from the people. The people, whom God has given dominium, delegate this power to the ruler. ${ }^{63}$ The very idea of democracy also presumes the existence of the People, for demos is the ancient Greek equivalent of the People and democracy presumes that the demos rules itself. Who is the People (or the nation for Sieyès) that exercises sovereignty and holds constituent power? What makes a group of individuals a people? This will be discussed in the section below.

${ }^{63}$ Martti Koskenniemi, "Conclusion: Vocabularies of Sovereignty- Powers of a Paradox" in Hent Kalmo \& Quentin Skinner, eds, Sovereignty in Fragments: The Past, Present, and Future of a Contested Concept (Cambridge: Cambridge University Press, 2010) 233. 


\section{Different Theories of the People}

\subsection{The People as an Outcome of a Contract}

Thomas Hobbes' theory of the state is one of the first to be built on the idea of the consent of the People. Writing during the English Civil War in the seventeenth century, Hobbes' starting point is that individuals, absent a government, live in a state of nature. The state of nature is a state of freedom, where an individual has the freedom to do whatever he (Hobbes was mainly talking about men) sees fit for his own survival. Self-preservation becomes the ultimate goal that justifies any action. This gives people a right "to all things". ${ }^{64}$ The result is that the state of nature is a miserable state of uncertainty and danger. The state of nature is a state of war, "where every man is Enemy to every man". ${ }^{65}$ To leave this miserable situation, Hobbes posits that individuals, led by the laws of nature, agree to give up some of their rights and enter into a covenant submitting to the authority of the sovereign. This sovereign, or Leviathan, or the Commonwealth, has absolute power and authority, and is able to protect the people's safety.

For Hobbes, the formation of the commonwealth as a result of the covenant turns the multitude into one artificial person that represents them all. The very formation of the commonwealth is what turns the crowd of individual persons into a People. The covenanting People for Hobbes are a single entity that has a single will. The sovereign's will is attributed to the People, thus in Hobbes' philosophy " $[\mathrm{t}] \mathrm{he}$ People rules in all Governments, for even in

${ }^{64}$ Thomas Hobbes, Leviatban, ed by Richard Tuck (Cambridge: Cambridge University Press, 1991) ch14 at 64 [Hobbes, "leviathan"].

${ }^{65}$ Ibid ch 13 at 62. 
Monarchies the People Commands; for the People wills by the will of one man." ${ }^{\prime 66}$ But then he distinguishes "the People" from "the Multitude"; the latter is the citizens or the subjects, they are not a People. The People is the ruling council or the king. ${ }^{67}$ What Hobbes calls the "Common-peoples", in contrast, have no role afterward. For "the Common-peoples minds", Hobbes claims, "are like clean paper, fit to receive whatsoever by Publique Authority shall be imprinted in them. ${ }^{, 68}$ The role of the People understood as the collective, therefore, ends after the moment of covenanting and the creation of the state.

John Locke starts from a similar premise: people exist in a state of nature, though his conception of this state is less gloomy than Hobbes. For Locke, the main point about the political order is consent - whether the People gave, or were thought to have given, consent to the government. ${ }^{69}$ Consent need not be explicit, and there are multiple ways of providing tacit consent. Locke goes further than Hobbes by giving the People the right to rebel against the government because "the Community perpetually retains a Supream Power of saving themselves from the attempts and designs of any Body, even of their Legislators, whenever they shall be so foolish, or so wicked, as to lay and carry on designs against the Liberties and Properties of the Subject." ${ }^{70}$ Still, like Hobbes, besides identifying the People as those who are thought to have consented, there is no definition of who is included in the group whose consent is sought.

Emmanuel Joseph Sieyès and Jean-Jacques Rousseau, both influential philosophers of the French revolution, did not provide adequate answers either. Sieyès seems to provide two

\footnotetext{
${ }^{66}$ Thomas Hobbes, De Cive, ed by Howard Warrender (Oxford: Clarendon Press, 1983) ch 12 at 8.

${ }^{67}$ Ibid.

68 Hobbes, "leviathan", supra note 64 ch 30 at 177.

${ }^{69}$ John Locke, The Second Treatise: An Essay Concerning the True Original, Extent, and End of Civil Government, ed by Ian Shapiro (New Haven: Yale University Press, 2003).

70 Ibid ch 13 at 149.
} 
conceptions of the nation which seem contradictory. For him, the nation, which is the source of all authority, is defined as "a body of associates living under common laws and represented by the same legislative assembly". ${ }^{71}$ In this definition he rejects ethnic distinctions among different components of the French people at the time (Gauls, Romans, Welches, etc).$^{72}$ However, the state of living under common goals and representation in an assembly presupposes an existing legal and political order if not a state. This definition, therefore, does not offer much clarity about the identity of the parties to the contract. To make things more ambiguous, in a different part of his "Qu'est-ce que le tiers-état?", Sieyès describes the process of the formation of the political society based on individuals who wish to unite to form the common will which becomes a representative common will as representatives are delegated a portion of the power needed to maintain order. ${ }^{73}$ Rousseau's social contract theory also presupposes certain conditions in the individuals before they form the social contract which turns them into the People. This presupposition indicates that Rousseau takes the foundations of the group as hypothetical. ${ }^{74}$ Kant also supports a consent theory but sees no need for actual consent as long as it is rational to consent. ${ }^{75}$ Similarly, contemporary theorists do not fare much better. John Rawls's theory of justice for example rests mostly on reasonable pluralism and not actual agreement. ${ }^{76}$

The common problem for the adherents of the contract theory is that the contract itself cannot decide who the parties are or should be. The social contracts, which are supposed

\footnotetext{
71 Sieyès, supra note 17 at 58.

$72 \mathrm{Ibid}$ at 60

${ }^{73} \mathrm{Ibid}$ at 121-122

${ }^{74}$ Loughlin, "The Idea", supra note 11 at 105.

${ }^{75}$ Kant supra note 42 at 61-92, 79.

${ }^{76}$ John Rawls, $A$ Theory of Justice (Cambridge: Belknap Press, 1971); John Rawls, Political Liberalism (New York: Columbia University Press, 1993).
} 
to be the basis of the state and the constitution, and thus of the highest order, cannot be decided without a higher order contract that decides who can participate. ${ }^{77}$ Contractarianism may help explain how an existing society could determine its political order, but it does not explain who is included and who is not. In addition, this conception of the people is open to manipulation and could be used (usually through creative interpretation) to exclude individuals and groups deemed undesirable. The infamous Dred Scott decision of the Supreme Court of the United States is a case in point. ${ }^{78}$

As will be discussed in chapter III, the Supreme Court of Israel used social contract theory a number of times to explain the foundations of the Israeli constitutional order. While it was used in a very abstract manner, the discussions in the relevant rulings show that the classic problem of contractarianism - the question of who is included in the contract emerges in a clear manner in the case of Israel. The definition as a Jewish state also adds a level of complexity and raises questions about the degree of inclusion of non-Jews in the social contract as active parties that can shape the contract and not just be subject to it.

77 Bert Van Roermund, "Sovereignty: Unpopular and Popular" in Neil Walker, ed, Sovereignty in Transition (Oxford: Hart Publishing, 2003) 40. Writing in 1763, Samuel Pufendorf suggests two contracts, but still his two contracts rest solely on consent. Samuel Pufendorf, On the Duty of Man and Citizen According to Natural Law, ed by James Tully, translated by Michael Silverthrone (Cambridge: Cambridge University Press, 1991) at 136.

${ }^{78}$ Dred Scott v. Sanford, 60 U.S. 393 (1857) (the Court held that people of African descent could not be considered citizens, among other reasons, because

[n]o one of that race had ever migrated to the United States voluntarily; all of them had been brought here as articles of merchandise. The number that had been emancipated at that time were but few in comparison with those held in slavery, and they were identified in the public mind with the race to which they belonged, and regarded as a part of the slave population rather than the free. It is obvious that they were not even in the minds of the framers of the Constitution when they were conferring special rights and privileges upon the citizens of a State in every other part of the Union." at 411-412).

See also Bosniak, supra note 7 at 24. 


\subsection{Homogenous Prior Existence: Schmittian Decisionism}

Contrary to social contract theories, Carl Schmitt's starting point is that "the concrete existence of the politically unified people is prior to every norm."79 The People are above and outside the constitutional norm. ${ }^{80}$ The People and the state get their meaning from the concept of the political..$^{81}$ The political rests on the irreducible distinction between friend and foe. This distinction "denotes the utmost degree of intensity of a union or separation, of an association or dissociation." ${ }^{\mathrm{82}}$ This distinction allows for the possibility of extreme conflict. The enemy exists where there is a potential that "one collectivity of people confronts a similar collectivity." 83 The enemy is also a public enemy not a private one, since it relates to the collectivity as a whole and not to the individual. This decision on friend and enemy is what decides the identity of the People. The friend-enemy grouping is so strong that it pushes aside any other criteria. "This grouping is therefore always the decisive human grouping, the political entity. If such an entity exists at all, it is always the decisive entity, and it is sovereign in the sense that the decision about the critical situation, even if it is the exception, must always necessarily reside there." ${ }^{\prime 84}$ The state which is the political entity of the political grouping endeavors to assure total peace and tranquility within its territory.

Schmitt elaborates more on the nature of the People in his Constitutional Theory. In his discussion of democracy, he states that the ideal of equality is central to democracy. Political

\footnotetext{
79 Carl Schmitt, Constitutional Theory, tarnslated by Jeffery Seitzer (Durham, NC: Duke University Press, 2008) at 166 [Schmitt, "Constitutional Theory"].

80 Ibid.

81 Carl Schmitt, The Concept of the Political, translated by George Schwab (New Brunswick, NJ: Rutgers University Press, 1976) at 20.

82 Ibid at 26.

83 Ibid at 28.

${ }^{84}$ Ibid at 38.
} 
democracy, however, rests "on the quality of belonging to a particular people." 85 This belonging is defined by elements such as "ideas of common race, belief, common destiny, and tradition." ${ }^{86}$ For Schmitt, the "substance of equality... resides in the national component." His conception of the nation is very particular. Members of the nation have "a politically distinctive consciousness." ${ }^{\prime 88}$ The unity of the nation and consciousness of this unity are preserved by a number of factors which include "common language, common historical destiny, traditions and remembrances, and common political goals and hopes." ${ }^{89}$ The definitive elements are "the commonality of historical life, conscious willing of this commonality, great events and goals." ${ }^{, 00}$ National homogeneity is important because lack of homogeneity is "abnormal" and seen as a threat to the peace. Homogeneity is a condition for substantive equality and democracy. ${ }^{91} \mathrm{~A}$ state with multiple nations or national minorities should either separate or assimilate the minority. Schmitt recommends the "elimination of the alien component through suppression or exile of the heterogeneous population"92 in order to achieve "democratic" equality which is essentially similarity among the People. ${ }^{93}$ Schmitt generally adopts a populist approach and defines the People in a negative manner by stating that there is nothing sociologically essential about them. Thus, the People are "everyone who is not honored, and distinguished, everyone not privileged, everyone prominent not because of

\footnotetext{
${ }^{85}$ Schmitt, "Constitutional Theory", supra note 79 at 258 [emphasis in original].

$86 \mathrm{Ibid}$ at 258.

87 Ibid at 261.

${ }^{88} \mathrm{Ibid}$ at 262.

${ }^{89}$ Ibid at 262.

${ }^{90}$ Ibid at 262.

${ }^{91}$ Cark Schmitt, The Crisis of Parliamentary Democracy, translate by Ellen Kennedy (Cambridge, MA: The MIT Press, $1985)$ at $9-15$.

92 Schmitt, "Constitutional Theory", supra note 79 at 262.

${ }^{93}$ Ibid at 263.
} 
property, social position or education." 94 The People are not a product of fiction; they are real and genuinely present. They could be seen in public assemblies that are not controlled by procedure. They could be seen in street demonstrations, public festivals, and stadiums. ${ }^{95}$

The People for Schmitt, therefore, are made by a political decision which is prior to law. Homogeneity is the central idea of peoplehood and democracy, and from the examples he provides (Greek-Turkish population exchange agreements of 1923), one can conclude that that he means ethnic homogeneity. For democracy to work, he suggests the word "identity" as part of the definition because it denotes the identity of the homogenous People which includes the governors and the governed. ${ }^{96}$ The People for Schmitt are a homogenous ethnos. The results of this conception of the People are very dire for those who do not belong to the ethnos, as this conception could justify a number of actions ranging from apartheid and ethnic cleansing to genocide. ${ }^{97}$

This ethnocentric and exclusionary conceptualization of the people bears some resemblance with some views expressed with relation to the situation in Israel, especially among right-wing groups. ${ }^{98}$ Mechanisms of exclusion, however, are not always as clear, stark and shocking as Schmitt's positions are. In many cases those are covert, benign, and can be found in mundane details. Some of those mechanisms will be explored throughout chapters III to VI.

${ }^{94}$ Ibid at 271.

95 Ibid at 272.

${ }^{96}$ Ibid at 264.

${ }^{97}$ See for example Joseph Weiler's description of how Schmitt's ideas were used to justify the exclusion and then genocide of German Jews, Joseph Weiler, "Demos, Telos and the German Maastricht Decision" (1995) 1:3 European Law Journal 219 at 251.

${ }^{98}$ It is important here to note Schmitt's anti-Semitism and his relations with the Third Reich. He is considered one of the main intellectuals who provided the "intellectual" grounds for the atrocities that were committed. Indeed, one can draw a direct line between his friend/enemy distinction and the emphasis on homogeneity and the Holocaust. On Schmitt's anti-Semitism see, David Dyzenhaus, Legality and Legitimacy: Carl Schmitt, Hans Kelsen and Hermann Heller in Weimar (Oxford: Clarendon Press, 1997) at 98-101. 


\subsection{Positivist Conceptions of the People}

Hans Kelsen is probably the best known theorist who dealt with the question of the foundation of the political and legal order from a positivist perspective. As opposed to Schmitt (who also happens to be his intellectual - and sometimes personal - adversary) who assumes the prior existence of a united homogenous political grouping that holds constituent powers, for Kelsen the People can only be approached from a normative sense.

To understand Kelsen's position, some details about his normative position on constitutions and legal systems should be provided, for his conception of the People is part of his larger theory of law, and his intellectual project of separating law from politics. In Kelsen's system, the validity of a norm is always derived from another higher norm. It could not be derived from other elements, such as a fact or the content of the norm. At the top of the normative hierarchy stands the basic norm, or Grundnorm. The basic norm prescribes one thing only - that the makers of the constitution, or the first constitution that validated the current constitution, were authorized to make it. The basic norm is a presupposed norm, and it presupposes the validity of the constitution..$^{99}$ Its function "is to found the objective validity of a positive legal order, that is, to interpret the subjective meaning of the acts of human beings by which the norms of an effective coercive order are created as their objective meaning." 100 Since the basic norm is the norm that the validity of all other norms stems from, Kelsen says that it "constitutes the unity of the multiplicity of these norms."101

\footnotetext{
99 Hans Kelsen, Pure Theory of Law, translated by Max Knigt (Berkeley: University of California Press, 1970) at 200-202.

100 Ibid at 202 [emphasis in original].

101 Ibid at 205.
} 
Where does the People fit in this theory? Since the validity of the norms and the whole legal system are based on a presupposed basic norm, then the People as a collective plays no role. Yet the People is needed for democracy, for Kelsen's definition of democracy "is the identity of the leader and the led, of the subject and the object of rule; it means the rule of the people over the people." 102 This definition requires a form of unity among the People; a unity which, as Kelsen acknowledges, does not exist for "the people" is "[s]plit by national, religious, and economic conflicts, that unity is...more a bundle of groups than a coherent mass of one and the same aggregate state." ${ }^{103}$ The People's unity is a fiction, and the only unity is the legal unity. The unity of the People is therefore "the unity of the state's legal order which rules the behavior of the human beings subject to its norms. In this unity and through the content of its norms, the unity of the variety of human action is constituted, which the 'people' as an element of the state, as a specific social order, represents." 104 The idea of the People for Kelsen is not necessary to legitimate the legal order. The legal order only refers to itself; it is the starting point and the end point.

Kelsen's Grundnorm is often used to explain some foundational aspects of the constitutional system in Israel. In the landmark Bank Mizrabi decision, former Chief Justice Barak invoked it as one of the theories to justify the Knesset's powers to adopt a constitution. ${ }^{105} \mathrm{~A}$ discussion of how Kelsen's theory is used in the context of the Israeli constitutional order will be discussed in chapter III.

102 Hans Kelsen, "On the Essence and Value of Democracy" in Arthur J. Jacobson \& Bernhard Schlink, eds, Weimar: A Jurisprudence of Crisis (Berkeley: University of California Press, 2000) 84 at 89.

103 Ibid at 90.

104 Ibid at 90.

105 Bank Mirrabi, supra note 46. 
Other liberal legal theorists follow a somewhat similar circular route. For them the People is created with the creation of the constitution. For liberal constitutional theory, while it presupposes the existence of the People, in reality it is the constitution that creates the People. As Neil MacCormick puts it, "[t]hey count as 'a people' by virtue of the constitution that makes them so." 106 In a similar vein, Joseph Weiler opines that "the demos which is called upon to accept the constitution is constituted, legally, by that very constitution". ${ }^{107}$ One may suggest that the formation of the People is a dynamic and fluid process that starts before the constitution and continues afterwards. As Ulrich Preuss suggests, the concept of the People should be thought of not as empirical entities but as "social constructs which embody the aspirations, the ideals, and the unity of the society and which are purified from all traces of its more trivial and disuniting attributes." ${ }^{108}$ While such a characterization highlights the aspiration for the unity of the society under the authority of the constitution, it also overlooks the fact that in most cases society is not really united. In some cases, the aspiration for unity of the people under a constitution is diminished by the certain constitutional provisions or principles. In Israel for example, the Supreme Court's view of the People as the collective of citizens, which represents a liberal aspiration for unity, is undermined by the strong emphasis on the Jewish definition and the self-determination of the Jewish people. This is one of the manifestations of the tension and contradiction in the Jewish and democratic definition that will be one of the themes running throughout the dissertation - the tension in the

\footnotetext{
${ }^{106}$ Neil MacCormick, "Questioning Sovereignty", supra note 29 at 131.

${ }^{107}$ Joseph Weiler, "Federalism Without Constitutionalism: Europe's Sonderweg” in Kalypso Nikolaidis \& Robert Howse, eds, The Federal Vision: Legitimacy and Levels of Governance in the United States and the European Union (Oxford: Oxford University Press, 2001) 54 at 56.

108 Ulrich Preuss, "The Exercise of Constituent Power in Central and Eastern Europe" in Martin Loughlin \& Neil Walker, eds, The Paradox of Constitutionalism: Constituent Power and Constitutional Form (Oxford: Oxford University Press, 2007) 216.
} 
contradictory aspirations of both having a universal inclusionary and unified People and at the same time maintaining a strong and special status of the Jewish collective within the same system.

\subsection{A Reflexive "We the People"}

An approach that rejects the three approaches examined above focuses on the collective nature of the act of "self-constitution". In discussing the collective "we the people" in the context of the European Union, Hans Lindahl provides an approach that focuses on the reflexive act of the collective. This approach combines an inquiry into the roles of democracy and reflexive identity in the creation of the polity.

Lindahl argues that the creation of the constitution starts with the constitution of the political unity through law, and then the constitution of the political order by the political unity. ${ }^{109}$ If we accept democracy as self-rule, that is, the identity of the ruler and ruled, we need to define what is meant by identity in order to identify the "we" of the "self" in "self-rule". Lindahl offers two interpretations - identity as "sameness" or as "selfhood". The former, which he calls, following Paul Ricoeur, idem-identity, evokes the question of "what am I?" and the latter, which he calls ipse-identity evokes the question of "who am I?". ${ }^{110}$ Ipse-identity is the relevant identity for discussing the first person plural "we" which denotes a collective sense of selfhood. When "we" acts together, this activity is reflexive in two senses: the action reflects that the group view themselves as a unity that intends to act collectively (the subject of an act),

\footnotetext{
109 Hans Lindahl, "Constituent Power and Reflexive Identity: Towards an Ontology of Collective Selfhood" in Martin Loughlin \& Neil Walker, eds, The Paradox of Constitutionalism: Constituent Power and Constitutional Form (Oxford: Oxford University Press, 2007) 22.

110 Ibid at 14.
} 
and at the same time, since they have an interest in the act, they are also the object. "The collective self", Lindahl posits, “exists' in the form of self-attributive acts by individuals. By exercising their constitutional rights, they retroactively take up the first-person plural perspective of a "We" that has (already) enacted a constitution in its own interest."112 Political unity in this sense is acquired by the attribution of the act to the collective self, and its continued existence relies on the renewal of such acts. This unity is therefore finite, and it only exists as a possibility. This provokes a constant question of "who are we?" which opens up the realm of collectivity. ${ }^{113}$

Martin Loughlin adopts this reflexivity. He suggests that modern constitutions should be understood within the frame of droit politique, to highlight their reflexive nature. Understanding the constitution as the product of self-attribution by the People allows him to acknowledge the authority of the constitution, and at the same time recognize its conditional and qualified character which leaves room for flexibility and change. This understanding, Loughlin argues, allows for reflexive constitutionalism. ${ }^{114}$

This approach, in a way, is a middle ground between Schmitt and Kelsen. From Kelsen it borrows some elements such as attribution and emphasis on the legal system and rejects the totally circular self-absorbed legal order. From Schmitt it borrows some of the ontological elements without subscribing to his position on the prior existence of a people and insistence on homogeneity as a condition for democracy. This reflexive approach will help guide the analysis in the dissertation. One of the questions that chapters III-VI will examine is

\footnotetext{
111 Ibid at 16.

112 Ibid at 19-20 [emphasis in original].

113 Ibid at 22.

${ }^{114}$ Loughlin, "Foundations", supra note 15 at 311.
} 
who is included in the People in Israel based on an examination of the different facets of the Israeli constitutional order, and what image of the People the constitutional order reflects.

\section{The People in Plurinational States}

The foregoing discussion of the concept of the People or the demos presupposed a monistic approach. The approach, which is one of the fundamentals of modern constitutionalism, assumes that the state will have one unitary demos. This emphasis on the unity of the People or the demos may come at the expense of minorities and marginalized groups that, in some respects, may not find their space within the sought unity. This raises questions about the ability of modern constitutionalism to adapt to cultural diversity.

James Tully highlights a number of features of modern constitutionalism that push either in the direction of uniformity or exclusion. Some of these features are closely linked to basic ideas and assumptions of constitutionalism. For example, Tully argues that a unitary and assimilative understanding of popular sovereignty exercised by uniform political association has resulted in a conception of the People that favors homogeneity and ignores cultural diversity. ${ }^{115}$ This tendency, especially in settler colonial states, was strengthened by the prevalent view that sees non-European cultures as inferior to European ones. This perceived inferiority in turn reinforced the notion that those belonging to those cultures should be "modernized" or "civilized" which gave a greater push for assimilation. ${ }^{116}$ Certain conceptions of the idea of equality could also be seen as tools of assimilation. By adopting a conception of equality that prioritizes identity and sameness rather than equity, modern constitutionalism

115 James Tully, Strange Multiplicity: Constitutionalism in an Age of Diversity (Cambridge: Cambridge University Press, 1995) at 63 [Tully, "Strange Multiplicity"].

116 Ibid at 65. 
contributed to assimilation. ${ }^{117}$ Tully concludes that the language of modern constitutionalism, "[w]hile masquerading as universal it is imperial in three respects: in serving to justify European imperialism, imperial rule of former colonies over Indigenous peoples, and cultural imperialism over the diverse citizens of contemporary societies."

Given these features that Tully identifies, it comes as no surprise that the monistic approach is often challenged by those who are excluded or assimilated. Sub-state nations and indigenous nations challenge the unitary nature of the demos and demand a role in the process of constitution-making as nations, or as constituent nations. ${ }^{119}$ The question of "who is the People?" in this case becomes more complex given the tension between the monist orthodox approach and the pluralism in the state. Here, it is helpful to distinguish between multinational states where the state contains two or more national groups, and a situation where the state was formed by settlers as part of a colonization process. Of course, both situations may be present at the same time, as was the case in Canada in 1867 and 1982.

\subsection{The People in Multinational States}

In a plurinational or multinational state, the founding is seen as a union between preexisting (and sometimes self-governing) Peoples who see themselves as distinctive peoples at the founding stage, and they continue to develop as discrete Peoples or demoi. The Peoples are usually territorially concentrated and sometimes self-governing and usually desire to maintain some form of self-governance. They see themselves as political units and not just cultural

\footnotetext{
117 Ibid at 66.

118 Ibid at 96.

${ }^{119}$ These demands of recognition and participation are not limited to national groups. Women, for example, also make similar demands for recognition and participation in what is essentially a male-dominated terrain. See Helen Irving, Gender and the Constitution: Equity and Agency in Comparative Constitutional Design (Cambridge: Cambridge University Press, 2008).
} 
units. ${ }^{120}$ In such states, recognition is often put forward as one of the ways to achieve genuine democracy in multinational states. ${ }^{121}$ Recognition could take various forms, including cultural, national, religious or linguistic rights or powers. The central idea is to recognize that within the state there are two or more nations who seek self-determination either externally in the form of secession, or internally, by reformulating the existing constitutional arrangement in a manner that recognizes and accommodates the diversity of the people within the state. ${ }^{122}$ Demands for recognition are not just symbolic. They affect the relationship between the state and the group seeking recognition and its members, and the relationship with other groups. Recognition also changes social, economic and political relations of power within the existing state. $^{123}$

How does this fit orthodox constitutional theory that sees the demos as one unity? Stephen Tierney finds Martin Loughlin's conception of sovereignty as the expression of the relationship between the People and the state to be useful in this regard. He adapts Loughlin's conception to plurinational states arguing that sovereignty should be seen as the expression of the political relationship between the state and the Peoples or demoi not just monistic people or demos. ${ }^{124}$ The constitution should be seen as an open, living and reflexive instrument that would give expression to the way the plurinational nature of the state is understood. Sovereignty should be seen as divisible or shared among the Peoples and not just limited to

\footnotetext{
120 Stephen Tierney, "We the Peoples': Constituent Power and Constitutionalism in Plurinational States" in Martin Loughlin \& Neil Walker, eds. The Paradox of Constitutionalism: Constituent Power and Constitutional Form (Oxford: Oxford University Press, 2007) 229 [Tierney, "We the Peoples"].

121 Tully, "Strange Multiplicity", supra note 115 at 184.

122 James Tully, "Introduction" in Alin-G. Gagnon \& James Tully, eds, Multinational Democracies (Cambridge: Cambridge University Press, 2001) at 3.

123 Ibid at 15.

${ }^{124}$ Stephen Tierney, "Reframing Sovereignty? Sub-State National Societies and Contemporary Challenges to the Nation-State" (2005) 54 International \& Comparative Law Quarterly 161 at 162.
} 
one "compound-demos" or the majority. ${ }^{125}$ Consequently, the constitution should be one that reflects the status of each sub-state nation as a demos, and not just as part of a bigger demos.

Such a conception of a sub-state nation as a People that shares sovereignty and constituent power as a people could be helpful in understanding constitutional disputes. The majority, for example, may adopt a hegemonic interpretation of the constitution that is contrary to the pluralistic nature of the state in a manner that would increase its powers or entrench its own interests. If the amendment procedures do not offer appropriate remedies, then a sub-state demos could assert constituent power from outside the constituted order in order to challenge the hegemonic approach of the dominant majority group. ${ }^{126}$

While the reality of the situation in Israel is that there are two national groups, or one can even say, two Peoples, there is no official recognition of the situation. As will be discussed in chapter III, the only group to be recognized as a nation is Jews, and this nation is the only one constitutionally affiliated with the state. The Palestinian minority is not even recognized as a national minority. The state only recognizes members of this group as religious or linguistic minorities. Not only is there no recognition of the Palestinians as a distinct People within the state, but serious doubts arise regarding their inclusion in the People in Israel.

\subsection{The People in Settler-Colonial Contexts}

Some multinational states came into being as a result of colonialism. Such states were formed by settlers who formed societies in colonies, which were separate and distinct from the local population. In most of these situations, the colonization process was accompanied by widespread processes of elimination of the indigenous population for a number of reasons,

125 Tierney, "We the Peoples", supra note 120 at 238.
126 Ibid 240-241. 
which included competition over control of land and resources. Though colonization in most cases started in the sixteenth to nineteenth century, the impact of settler colonialism and the ideologies that justified it still have strong implications for settler colonial states, including constitutionalism in those states.

Settler colonial states have employed what is called "internal colonization" in order to control the indigenous populations. Internal colonization could be defined as the historical processes by which indigenous peoples and their territory were placed under structures of domination. ${ }^{127}$ These structures either "incorporate" or "domesticate" the indigenous population turning them into dependent minorities in the state. ${ }^{128}$ The process of internal colonization was shaped by the needs of the settler society and capital markets, and also by the resistance of the indigenous people to the colonization process. ${ }^{129}$ Colonization has resulted in vast reductions of indigenous populations, their displacement and the elimination of their forms of governance. ${ }^{130}$ While this kind of colonialism is different from the classic external colonization of "salt water colonies", it is still colonialism in that the colonizing society exercises exclusive jurisdiction over the territory of the state, including the territories inhabited by indigenous people. The essence of internal colonization, Tully says, is "the appropriation of the land, resources and jurisdiction of the indigenous peoples, not only for the sake of resettlement and exploitation (which is also true in external colonization), but for the territorial foundation of the dominant society itself."131 Given that the essence of internal

${ }^{127}$ James Tully, "The Struggles of Indigenous Peoples for and of Freedom" in Duncan Ivison et al, eds, Political Theory and the Rights of Indigenous Peoples (Cambridge: Cambridge University Press, 2000) 37 [Tully, "The Struggles"].

128 Ibid at 37-38.

129 Ibid at 38 .

130 Ibid at 39.

131 Ibid. 
colonization is conflict over jurisdiction, settler societies, through their states, usually pursue two strategies. The first is the elimination of the indigenous population, ${ }^{132}$ either physically or culturally through assimilation or marginalization, and the second is through the elimination or extinguishment of the rights/demands of the indigenous groups. ${ }^{133}$

Different solutions have been suggested to the problem of colonialism. Tully for example suggests a strategy of self-determination as decolonization which includes recognition of indigenous people as free, equal and self-governing under international law, entitled to shared jurisdiction over the land and resources on the basis of mutual consent. ${ }^{134}$ The condition of consent should apply to legislation and the constitution in order to fulfill the requirement of self-governance and popular sovereignty. ${ }^{135}$ Writing in the Canadian context, Patrick Macklem suggests an approach that focuses on constitutional law and its role in distributing political rights and sovereignty. He characterizes sovereignty as a good and argues that a constitutional order should take into consideration the distinct culture and therefore different interests, needs and status of indigenous Peoples in the distribution of sovereignty and constitutional rights. ${ }^{136}$ Only an order that takes this relevant difference into account would uphold the principle of equality. ${ }^{137}$ Equality in this context is understood as equality of Peoples and not just equality of individuals. ${ }^{138}$ Macklem goes on to suggest that this difference could find expression in an understanding of internal sovereignty which would allow

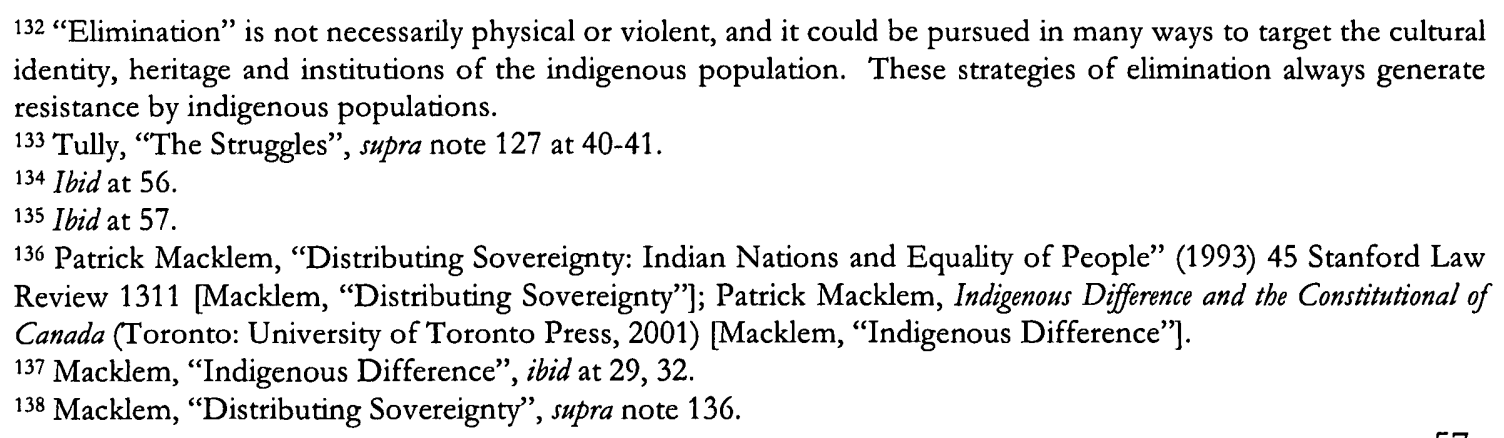

132 "Elimination" is not necessarily physical or violent, and it could be pursued in many ways to target the cultural identity, heritage and institutions of the indigenous population. These strategies of elimination always generate resistance by indigenous populations.

133 Tully, "The Struggles", supra note 127 at $40-41$.

134 Ibid at 56.

135 Ibid at 57.

136 Patrick Macklem, "Distributing Sovereignty: Indian Nations and Equality of People” (1993) 45 Stanford Law Review 1311 [Macklem, "Distributing Sovereignty"]; Patrick Macklem, Indigenous Difference and the Constitutional of Canada (Toronto: University of Toronto Press, 2001) [Macklem, "Indigenous Difference"].

${ }^{137}$ Macklem, "Indigenous Difference", ibid at 29, 32.

138 Macklem, "Distributing Sovereignty", supra note 136. 
indigenous peoples to express their collective difference. ${ }^{139} \mathrm{~A}$ measure of internal sovereignty that does not encompass the totality of powers in the state would allow indigenous people a better standing in the state, and would enhance substantive equality in the distribution of constitutional entitlements. This would allow them more control over their collective and individual identities. ${ }^{140}$

The applicability of the settler colonialism model to Israel and the Zionist movement is contested. On the one hand, as early as the 1960s, many academics have described the Zionist project and the formation of the state of Israel as a form of settler colonialism. ${ }^{141}$ Those writers highlighted the fact that the Zionist movement started in Europe with the majority of the Israeli society (at least until the late 1960s) having been recent immigrants from mostly European states. They also emphasized certain features that are characteristic of settler societies such as the effort to control the land at the price of dispossessing and displacing the native population, deep antagonism and conflict with the native population, and separation between the settler society and the native society. On the other hand, this perspective has been rejected by many other academics who highlight the historical, cultural and religious ties between the Jewish people and the region. They argue that Jewish settlement

${ }^{139}$ Macklem, "Indigenous Difference", supra note 136 at 110.

140 Ibid at 111.

141 See e.g. Fayez Sayeg, Zionist Colonialism in Palestine (Beirut: Research Center - Palestine Liberation Organization, 1965); George Jabbour, Settler Colonialism in Southerm Africa and the Middle East (Khartoum: The University of Khartoum and the Palestine Liberation Organization Research Centre, 1970); Maxime Rodinson, Israel: a Colonial Settler State? (New York: Monad Press, 1973); Elia T. Zureik, The Palestinians in Israel: A Study in Internal Colonialism (London: Routldge \& Kegan Paul, 1979); Edward Said, The Question of Palestine (New York: Times Books, 1979); Nahla Abdo \& Nira Yuval-Davis, "Palestine, Israel and the Zionist Settler Project" in Daiva Stasiulis \& Nira Yuvl-Davis, eds, Unsettling Settler Societies (London: Sage Publications, 1995); Lorenzon Veracini, Israel and Settler Society (London: Pluto Press, 2006); Gershon Shafir, "Zionism and Colonialism: A Comparative Approach" in Ilan Pappe, ed, The Israel/Palestine Question, 2d ed (London: Routledge, 2007); Gabriel Piterberg, The Returns of Zionism: Myths, Politics and Scbolarship in Israel (London: Verso, 2008); Amal Jamal, Arab Minority Nationalism in Israel (London: Routledge, 2011). 
in Palestine cannot be seen as colonialism since it is the Jewish ancestral land. ${ }^{142}$ Some writers distinguish Zionist colonization from other forms of colonization arguing that the Zionist immigrants were not sent by a colonial power as in, for example, North America or Australia. In between the two approaches, some, like Baruch Kimmerling adopted the settler/native analysis but without using the term settler colonialism. ${ }^{143}$

As contested as this question may be, it is hard to escape the observation that what happened in the area of historic Palestine in the past 100 years fits Tully's definition of "internal colonization", that is, the appropriation of land, resources and jurisdiction for the benefit of the settler society. Similarly, it fits the definitions of theorists of settler colonialism such as Patrick Wolfe, who, speaking in the context of Australian settler-colonization, identifies settler colonialism's essential feature as "the logic of elimination, a sustained institutional tendency to supplant the indigenous population which reconciles a range of historical practices that might otherwise seem distinct". ${ }^{144}$ Indeed, Wolfe even observes that the Zionist logic of elimination is more exclusive than in Australia or the United States. ${ }^{145}$ The creation of the state of Israel, the events preceding it, the mobilizing ideologies, and the laws and policies adopted afterwards, all share more with settler colonial states than any other type of states.

\footnotetext{
${ }^{142}$ See e.g. Alan Dershowitz, The Case for Israel (Hoboken, NJ: John Wiley \& Sons, 2003); Tuvia Frilling ed, An Answer to a Post-Zionist Colleague (in Hebrew)(Tel-Aviv: Yedi'ot Aharaonot Publiser \& Sefrei Hemed, 2003); Amnon Rubenstein \& Alexander Yakobson, Israel and Family of Nations (New York: Routledge, 2009); Ruth Gavison, "The Jews' Right to Statehood: A Defense" (2003) Azure 70; Ran Aaronsohn, "Settlement in Eretz Israel: A Colonial Enterprise? 'Critical' Scholarship and Historical Geograpy" (1996) 1:2 Israel Studies 214.

${ }^{143}$ Baruch Kimmerling, Zionism and Territory: The Socio-Territorial Dimensions of Zionist Politics (Berkeley: Institute of International Studies, 1983); Baruch Kimmerling, Clash of Identities: Explorations in Israel and Palestinian Societies (New York: Columbia University Press, 2008).

144 Patrick Wolfe, "Nation and MiscegeNation: Discursive Continuity in the Post-Mabo Era" (1994) 36 Social Analysis 93 at 96.

145 Patrick Wolfe, "Purchase by Other Means: The Palestinian Nakba and Zionism's Conquest of Economics" (2012) 2:1 Settler Colonial Studies 133 at 136.
} 
Colonialism takes a distinct form in Israel, which could be understood as a mix between settler colonialism and internal colonialism. To what extent does this affect the Israeli constitutional edifice and the way it functions? To what extent does the Israeli constitutional system give effect to the logic of colonialism? While the overarching argument of the dissertation does not hinge on viewing the situation of the Palestinian citizens through the lens of settler colonialism, or a conflict between settlers and natives, it may prove helpful for understanding the logic behind many laws and policies in Israel.

\section{Summary and Conclusions}

On the constitutional level, according to most approaches whether liberal, republican or critical, the idea of democracy is very closely related to popular sovereignty and constituent power. All three concepts have the People as their referent. Democracy means self-rule of the People. Sovereignty, whether conceived of as popular sovereignty, or as a relationship between the People and the governing authority, refers to the People. Constituent power, at least in a democracy, is seen as vested in the People. Even when the use of the People is fictional in nature, as in Kant's approach, who prefers reason to actual consent, still his reason relies on what the People could possibly and reasonably agree on. This highlights the centrality of the concept of the People for the creation of a democratic legal and political order. Whether through consent, reason, elections, or active participation in any other way, democratic government gains its legitimacy from the People. The People are, or at least are supposed to be, the ultimate source of political power.

This insight into the relationship between the People and the constitution, which is mediated by sovereignty and constituent power, could be helpful in answering the question of 
"who is the People in Israel?". As mentioned in the introduction, given Israel's definition as a Jewish and democratic state, it is not entirely clear who the People is in Israel. My inquiry into the question of "who is the People?" will proceed in a different way. I will examine the question of the People in Israel through the prism of the constitution (or constituted form generally which also includes laws, policies and institutions). The constitution will be used as the prism to examine who holds constituent power or sovereignty; put differently, by examining different facets of the constitutional regime, one can identify the source of ultimate political power that exercises the sovereignty and holds constituent power, and thus who the People is. So here, rather than uncritically posit that the People in Israel are the collective of citizens who exercise sovereignty through constituting the constitution and voting, I will take the opposite approach: I will use Israel's constitutional regime, statutes and policies, as manifestations of sovereignty in order to locate the source of ultimate political power and authority. In this way, I will examine what constitutional theory has to tell us about Israel's definition and character, and whether the distinction between the nation and the People is possible. Before proceeding in this line of inquiry, I will first review the different approaches to the question of the meaning of the Jewish and democratic definition, and how the different approaches deal with the questions of the People and sovereignty. This will be the focus of chapter II. 


\section{Chapter II}

\section{A Jewish and Democratic State: Theoretical Justifications and Critiques}

\section{Introduction}

As reviewed in the previous chapter, on the foundational/constitutional level, democracy is related to sovereignty in its internal sense and constituent power. The People, exercising sovereignty and using constituent power, create and maintain the constitutional order. The legitimacy of the constitutional order is predicated on the consent and participation of the People. The idea of the People is therefore important to the constitutional order and democracy. Deciding who is included in the People therefore becomes an important question that is related to the legitimation of the constitutional order and democracy. This question is especially complex in Israel, given its definition as a "Jewish and democratic" state. The definition itself provides two different and contradictory ways of seeing the People. The Jewish element denotes that the People is the Jewish people, while the democratic element implies a more inclusive conceptualization of the People. This internal tension and contradiction within the "Jewish and democratic" definition was the subject of discussion for a long time, with various writers suggesting different approaches to understand, analyze, overcome, conceal or emphasize the tension. Focusing on the discussion of the definition on the national level only, this part of the dissertation will examine the different approaches to the interpretation of the terms "Jewish and democratic", with the common thread being the tension between the terms, attempts at resolving it, and how each approach sees the People in Israel. 
The categories were chosen to describe a spectrum of approaches to the meaning of the "Jewish and democratic" definition. I begin with what I call the ultra-nationalist approach: that of Rabbi Meir Kahane and his school of thought. The second approach is the nationalist approach, which will include the main theorists and commentators who have approached the tension from a point of view that is more favorable to and accommodating of the nation - the nation here being the Jewish nation. Some of those included in this category would not likely self-identify as nationalist, still, the categorization will focus on the actual arguments and less on the self-perception of the scholars engaged. I call the third category the pragmatic approach. It includes theorists who justify the definition either by downplaying or overlooking the tension through an intensive process of interpretation and abstraction that overlooks many problematic aspects, or by adopting new theoretical models as a means to explain and justify existing realities. I discuss liberal approaches as a fourth category. The main difference between this category and the first three approaches is that the writers discussed here exhibit a stronger commitment to liberalism in analyzing and trying to resolve the tension. While all of the authors in first the three categories self-identify as Zionist, the fifth category - which I will call the critical approach - will include the non-Zionist and anti-Zionist critics of the Jewish and democratic definition. They are more critical of the status quo, and more skeptical of the possibility of resolving the tension in the definition. This dissertation is part of this approach.

While this review is by no means a comprehensive one, it is representative of the major schools of thought on this debate and will focus mostly on the leading voices who have contributed to the debates. Similarly, even within each of the categories, there is a range of perspectives. The task of categorization is useful for it provides us with a range of views on 
the meaning of the "Jewish and democratic" definition and its implications. Furthermore, as chapters III-VI show, in some cases, theoretical debates on the "Jewish and democratic" definition influence and sometimes inspire some of the decisions adopted by the courts.

\section{Ultra-Nationalist Approachs}

Proponents of this approach understand the Jewish state as a state where Jews only can be citizens, and where non-Jews, mainly the Palestinians, are temporary residents, or, as Rabbi Meir Kahane, ${ }^{1}$ the exemplar of this category, put it, are lodgers not owners. ${ }^{2}$ For Kahane, the Jewish state cannot be democratic. The contradiction between the two is ultimate and insoluble." Kahane asks the question "[w]ould Israel allow the Arabs through peaceful democracy to become a majority? If that question can be asked, no Arab is really equal. If that question can be answered in the affirmative, there is no Jewish state."4 Kahane's views included the mass transfer of the Palestinians and other racist ideas. He was elected to the Knesset in 1984, but was banned in 1988 after Basic Law: The Knesset was amended to ban the participation of candidates whose platform promotes racism.

Kahane's extreme ideologies are rooted in the belief that the source of authority is religious. He sees the Bible as the true constitution that has been abandoned for a distorted human-made one. ${ }^{5}$ Yet his approach was not purely religious. It combined religious extremism with hyper-nationalism. There is no real engagement in his approach with the tension

\footnotetext{
${ }^{1}$ Rabbi Meir Kahane is the founder and leader of the Jewish Defense League and the "Kakb" movement. His ideology combines religious zealotry with ultra-nationalist fervor. He encouraged the use of violence and advocated for a religious Jewish state on all of Mandate Palestine which would expel the Palestinians. See, Yair Kotler, Heil Kabane (New York: Adama Books, 1986).

2 Meir Kahane, They Must Go (New York: Grosset \& Dunlap, 1981) at 119-120 [Kahane, "They Must Go"].

${ }^{3}$ Ibid at 117; Meir Kahane, Uncomfortable Questions for Comfortable Jews (Seacaucus, NJ: Lyle Stuart Inc., 1987) at $160-163$.

${ }^{4}$ Kahane, “They Must Go", ibid at 199.

5 "Meir Kahane's speech in the Knesset on 7 June 1988", online: Memorial Website for Rabbi Kahane

<http://www.rabbikahane.org/ArticleView.aspx?id=6.31>.
} 
between "Jewish" and "democratic", but rather an assertion that the tension is irresolvable and that a Jewish state cannot be truly democratic. Succinctness and clarity may be its most positive attributes, yet it is flawed in a major way - the approach is extremely racist and usually includes a strong call for the denaturalization and forcible deportation of all Palestinians, which is a crime against humanity under international law. ${ }^{6}$

Though Kahane was banned from participating in the elections and his party was declared a terrorist organization in 1994, many of his ideas still enjoy popular support in Israeli politics. One former Kahanist activist, Michael Ben Ari, was elected to the Knesset in 2009. Moshe Feilgin, currently a Member of Knesset and its Deputy Speaker for the Likud party, has similar - although not identical - views to Kahane. He offers legal residency to all Palestinians instead of citizenship and supports encouraging their emigration, with transfer being the long-term goal. ${ }^{7}$

Even if not presented as a full political program, some strands of ultra-nationalist thinking can be identified in almost all aspects of life. The main difference is that democracy is not rejected outright as in the case of Kahane, and the characterization of "Jewish and democratic" is not seen as a contradiction in terms. For example, many Israeli parties, politicians and intellectual figures even justify some sort of population transfer or populationexchange. ${ }^{8}$ Some support making citizenship contingent on a certain conception of loyalty to

${ }^{6}$ Article 7(1)(d) and (h) of the Rome Statute of the International Criminal Court (1998) entered into force 1 July 2002.

${ }^{7}$ Moshe Feilglin, Dreams War: From the State of the Jews to the Jewish State (in Hebrew) (np: Jewish Leadership, 2005) 516-518.

${ }^{8}$ See e.g. the "Issues" section of the website of the Yesra'el Beytenu, a senior partner in the current ruling coalition and the party headed by former Minister of Foreign Affairs Avigdor Leiberman. Under "National Security" the website has the heading "A Territory and Population Exchange". The party justifies the calls for population exchange because of the risk that "the State of Israel would become a binational state with a minority population of more than $-20 \%$. Such a model is not sustainable. It would only be a matter of time before Israeli- 
which Palestinian citizens will have to explicitly commit. ${ }^{9}$ Calls to limit the rights of Palestinians to participate in politics are made continuously. ${ }^{10}$ Many prominent figures, especially Rabbis, openly advocate a ban on leasing apartments to Arab citizens. ${ }^{11}$ Relationships between Palestinians and Jews are discouraged and are seen as a legitimate topic for discussion in the Knesset. ${ }^{12}$ Organizations with the mandate of promoting segregation receive state funding and support. ${ }^{13}$

To sum up, this approach promotes the Jewish element over the democratic. Democracy is for Jews only. It also includes a strong religious element that nurtures the ultranationalist sentiments. For the ultranationalists it is clear that Jews, and Jews only, are the People in Israel; all of the others, to borrow Kahane's quote again, are lodgers not owners. This approach is represented in Israeli politics on almost all levels including Israel's major political parties and the ideas it promotes are part of legitimate public discourse.

Arabs start demanding some form of autonomy in the Galilee and Negev, for example. The next stage would be the de facto dismantling of Israel as a Jewish and Zionist state." "National Security", online: Israel Our Home <http://www.beytenu.org/national-security/>. See also the call by former Member of Knesset Efi Eitam to "remove Israeli Arabs from the political system" Efrat Weis and Ilan Marciano, "Eitam: To Expel the Arabs from the [West] Bank- and from the Knesset" Ynet (11 June 2006), online: <http://www.ynet.co.il/articles/0,7340,L-3302258,00.html >.

9 Barak Ravid, "Leiberman: Peace Talks Must Reassess Israeli-Arabs' Right to Citizenship" Haaretz (19 September 2010), online http://www.haaretz.com/news/diplomacy-defense/lieberman-peace-talks-mustreassess-israeli-arabs-right-to-citizenship-1.314596. See also the platform of the National Union Party for the 2009 elections that provides that the "National Union shall act in order to revoke the citizenship of citizens who undermine the existence of the State as a Jewish state or who identify with its enemies, and will act to encourage the emigration of citizens that are not loyal to the state of the Jews. The National Union shall act for the Druze and Arabs who support Israel as the state of the Jews". See "Principles of the National Union Platform" online:

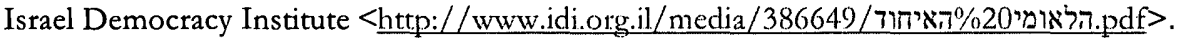

10 Efrat Weis and Ilan Marciano, supra note 8.

11 See for example the letter issued by 50 Rabbis in 2010, see Kobi Nahshoni, “50 Municipal Rabbis: Don't Rent Flats to Arabs" YnetNews (12 July 2010), online: <http://www.ynetnews.com/articles/0,7340,L3995724,00.huml>.

12 This issue was discussed by the Knesset Committee on Alyia, Absorption and Diasporas under the agenda item of "Abduction of Female Immigrants by Minorities- Urgent Discussion" (28 December 2011), available online <http://www.knesset.gov.il/protocols/data/rtf/alia/2011-12-28.rtfl .

${ }^{13}$ See for example Moriah Ben Yosef, "Tel-Aviv: The Municipality Launches a Program to Prevent Relationships Between Jewish Women and Minorities" NRG Maariv (23 February 2010), online: $<$ http://www.nrg.co.il/online $/ 54 / \mathrm{ART}^{\prime} 2 / 066 / 580 . \mathrm{htm} l$ hp $=54 \&$ loc $=4.8 \mathrm{tmp}=7464>$. 


\section{The Nationalist Approach}

\subsection{Conceptual Justification}

The common theme that unites the writers under the nationalist approach is their strong emphasis on the right to national self-determination, placing it at the centre of their argument for the Jewish and democratic state. A Jewish state, as explained by adherents of this approach such as Ruth Gavison, Amnon Rubenstein, Alexander Yakobson, Shlomo Avineri and Claude Klein, is the state where the Jewish people exercise their right to self-determination and independence - the Jewish people being a modern nation which is also united by a religion, but is not necessarily religious or defined by religion. ${ }^{14}$ Although created first and foremost for Jewish self-determination, the state should also be committed to human rights and liberal values. Many of the adherents of this approach, if not all, would identify as liberal or liberal nationalist, and try to wrestle with reconciling Zionism with liberal democracy. Their emphasis on the Jewish element, however, is stronger than the weight they attach to liberal values. Probably, a better way to describe them is the nationalist wing of the liberal nationalists, but for the sake of simplicity and to distinguish them from other liberal nationalists, I will call them nationalist.

The nationalists see Israel as the nation state of the Jewish people. They define the nation state as "a framework for organizing nations on national, ethnic, cultural, historical,

\footnotetext{
${ }^{14}$ While the discussion here will focus mostly on the writings of Ruth Gavison and Amnon Rubenstein - because they provide the most detailed and thorough discussion of the issues discussed- other writers could be included in this category, such as Shlomo Avineri, Claude Klein and Menachem Elon. See Shlomo Avineri in The State of Israel as a Jewish and Democratic State: A Discussion and Related Source (in Hebrew), Ron Margolin, ed, Jerusalem: International Association for Jewish Studies, 1997) 36 at 40; Claude Klein, Israel as a Nation State and the Problem of the Arab Minority: In Search of a Status (Tel-Aviv: International Center for Peace in the Middle East, 1987); Menachem Elon, "Constitution by Legislation: The Values of a Jewish and Democratic State in the Light of the Basic Law: Human Dignity and Personal Freedom” (in Hebrew) (1992-1993) 17 Iyunei Mishpat 659.
} 
religious basis within a state framework". ${ }^{15}$ In this kind of state, there is "a relationship between the state institutions and a particular national culture, it provides important advantages to the people that the state is associated with, and imposes a heavy burden on the citizens who do not belong to that nation." proponents of this approach started using the term "a democracy with a mission". ${ }^{17}$ This conception of the nation state stands in opposition to another conception which views the state as being the "state of all of its citizens", where the nation is made up of the body of all of the citizens, and "nation-building" is the process of strengthening the relationship between the state and the citizens. ${ }^{18}$ The nationalist approach asserts that Israel was not formed for the people who resided in the area that came under its sovereignty, but as a particularistic state; one that is designated to a specific group. To support this position, adherents of this approach cite the UN Partition Plan, ${ }^{19}$ which also used the term "Jewish State", and argue that creating a state for a particular (ethnic/religious) group was its underlying assumption. ${ }^{20}$ They further argue that since the definition's primary rationale is national self-determination, the definition as a Jewish state is a human rights issue because the right to self-determination is recognized as a human right under international law. Jewish self-determination in a state carries with it an

\footnotetext{
${ }^{15}$ Ruth Gavison, Israel as a Jewish and Democratic State: Tensions and Possibilities (in Hebrew) Jerusalem: VanLeer and Hakibutz Hameuhad, 1999) at 26 [Gavison, "Israel"].

${ }^{16}$ Ruth Gavison, "The Jewish State: The Principle Justification and the Desirable Character" (in Hebrew), (2002) 13 Tkhelet 50 at 54 [Gavison, "The Jewish State"].

17 See Shlomo Avineri, Liav Orgad \& Amnon Rubenstein, Managing Global Migration: A Strategy for Immigration Policy for Israel Jerusalem: The Metzilah Center, 2010) at 27, online: <http://www.metzilah.org/English/Immi_Book\%20final.pdf $>$. Ruth Gavison is the head of this Centre. In the original Hebrew publication the term used instead of "democracy with a mission" was "designated democracy". 18 Gavison, "Israel", supra note 15 at 26.

19 UNGA Resolution 181 (29 November 1947) recommending the partition of Mandate Palestine into a Jewish state and Arab state.

${ }^{20}$ Gavison, "Israel" supra note 15 at 26; Amnon Rubenstein \& Alexander Yakobson, Israel and Family of Nations (New York: Routledge, 2009) at 2.
} 
important requirement of a Jewish majority. A Jewish state means a Jewish majority. The protection and maintenance of the Jewish majority in Israel, they argue, is a right of this majority - a right that can and should be exercised without breaching the human rights of others. $^{21}$

The central pillar of this approach (national self-determination) is supported by another two main pillars which are crucial for its internal coherence and consistency. The second pillar is the idea of the partition of the area of historic Palestine into two states or political entities, one for Jews and one for Arabs, or, simply stated, "two states for two nations (or peoples)". The recognition of the self-determination of the Jewish people in the form of a state in the area of Mandate Palestine where Jews were a minority also means the need to recognize the self-determination of the other national group, the Arabs, in their own state. Given that the Jewish state would be the nation state of the Jewish people, the Palestinian state would also be the nation state for the Palestinian people, hence the formula of "two states for two people". ${ }^{22}$ The third pillar is international recognition. ${ }^{23}$ This came in the form of the Balfour Declaration of 1917 promising a Jewish national home in Palestine, ${ }^{24}$ and the articles of the Palestine Mandate of 1922 which adopted the Balfour Declaration and imposed

\footnotetext{
21 Amnon Rubenstein \& Liav Orgad, "Human Rights, State Security and Jewish Majority: The Case of Immigration for the Purpose of Marriage" (in Hebrew) (2006) 48 HaPraklit 315, 342-343; Ruth Gavison, "Thoughts about the Significance and Implications of "Jewish" in the Expression "A Jewish and Democratic State"”, in Aviezer Ravitzky \& Ydidia Z. Stern, eds, The Jewishness of Israel (In Hebrew) (Jerusalem: Israel Democracy Institute, 2007) 107, 136-137 [Gavison, “Thoughts"].

22 Rubenstein and Yakobson, supra note 20 at 8; Gavison, "Thoughts", ibid at 132-133.

${ }^{23}$ Rubenstein and Yakonson, supra note 20 at 12-64; Gavison, "The Jewish State", supra note 16 at 63; Ruth Gavison, Conditions for the Prosperity of the State of Israel: Without a Vision, the People Will Pay the Price: A Mega Puppose for Israel and its Implications (in Hebrew) (Haifa: The Samuel Neaman Institute for Advanced Studies in Science and Technology, 2006)

at

45 online: $<$ http://www.neaman.org.il/Neaman2011/userdata/SendFile.asp?DBID =1\&LNGID=2\&GID =2136>. [Gavison, "Conditions for Prosperity"].

${ }^{24}$ The Balfour Declaration (2 November 1917), online: <http://avalon.law.yale.edu/20th century/balfour.asp $>$.
} 
on the United Kingdom, as the Mandatory, the responsibility to "secure the establishment of the Jewish national home", ${ }^{25}$ and finally, the 1947 United Nations General Assembly Resolution 181 which adopted the Partition Plan. All of these documents, it is argued, represent international acceptance of the right to self-determination, and recognition of the Jewish character of the state. In addition to these pillars, the nationalists see Israel's Jewish definition as part of its democratic character. Thus, the Jewish character of the state is one of the manifestations of democracy since it reflects the wishes of the majority of the people. The existence of a Jewish majority, therefore, is seen as one of the most important practical meanings of having a Jewish state and at the same time, one of the justifications for defining the state as a Jewish state. ${ }^{26}$

\subsection{Resolving the Tension}

The starting point of the nationalists is that there is no conceptual contradiction between the two elements of the definition, and that any problems that Israel faces in dealing with its non-Jewish minority are not dissimilar to the problems that other nation states face. ${ }^{27}$ To the extent that there are defects in Israeli democracy, especially concerning equality and its implementation, those are defects that are not rare in other democratic regimes. ${ }^{28}$ Although they assert that there is no contradiction, the nationalists acknowledge the existence of

\footnotetext{
25 Preamble and Art. 2 of the Palestine Mandate (24 July 1922).

26 Gavison, "Israel" supra note 15 at 36; Rubenstein and Yakobson, supra note 20 at 125; Avineri, supra note 14 at 38.

${ }^{27}$ Gavison, "Thoughts", supra note 21 at 131; Rubenstein and Yakobson, supra note 20 at 3.

${ }^{28}$ This was mentioned in the Hebrew edition of the book published in 2003, no equivalent statement appears in the English edition. Amnon Rubinstein \& Alexander Yakobson, Israel and the Family of Nations: A Jewish Nation State and Human Rights (in Hebrew) Jerusalem: Schoken Publishing House, 2003) at 242.
} 
tension. This tension is best dealt with by trying to reconcile the two values and by dealing with dilemmas that the tension creates. ${ }^{29}$

The first way they deal with the tension is by attempting to normalize it and downplay its actual impact on the rights of the citizens. The tension, Rubenstein and Yakobson argue, is like any other tension between two legitimate values. ${ }^{30}$ They mention examples of tensions between legitimate values that modern societies have to deal with such as the tensions between individual liberty and equality, civil liberties and public safety, equal opportunity in education and competition and excellence. ${ }^{31}$ The tension, they argue, does not mean that either value should be seen as undesirable, or that it is necessary to decide between the values. One may ask, however, to what extent these examples are analogous to the tension in "Jewish and democratic." These examples reflect values that are general in nature which are justified by highlighting their benefits to the society as a whole. In this case, the tension in "Jewish and democratic" is between a universal value (democracy) and a particular value, which benefits the majority group only and inversely impacts the minority. This is essentially a rationalization of the existence of the tension that is used to avoid a deeper examination.

The second way nationalists deal with the tension is the comparative method, by asserting that most democratic states (or sometimes, as the argument goes, nation states) adopt similar policies. This method is another face of the normalization strategy. By examining laws, policies and practices in other states, the nationalists try to establish that Israel's definition and Israeli democracy are in line with the human rights norms as accepted

\footnotetext{
${ }^{29}$ Rubenstein and Yakobson, supra note 20 at 124-125; Gavison, "Israel" supra note 15.

30 Gavison says that there are only few ideals that do not have internal tension. Gavison, "Conditions for Prosperity", supra note 23 at 118.

${ }^{31}$ Rubenstein and Yakobson, supra note 20 at 124.
} 
by "the free world." 32 The argument posits that other liberal nation states adopt similar policies favoring an ethnically defined majority. Israeli policies therefore can be justified and should not be used to question Israel's democracy. This comparative approach has been criticized on a number of grounds. Chaim Gans for example argues that the fact that different states engage in unacceptable policies or violate certain human rights should not be used as a justification for adopting such policies. The "everybody does it" argument, Gans says, "is an apologetic argument usually invoked in order to justify something which is unjust and is usually not invoked in order to justify something which is just in its own right."33 Furthermore, some scholars have questioned the comparative method used. Nimer Sultany, for example, argues that Rubenstein and Yakobson are selective in using a comparative method in order to achieve the lowest common denominator. They rely on a functionalist approach to comparative law, which assumes that institutions and laws serve the same function in different countries. Since similarity is the starting point, it follows as a matter of course that the institutions and laws compared are similar. Sultany also criticizes the method as an attempt to avoid a real engagement with liberal democracy using the pretext that its focus is mainly on the practices of states rather than the theories. ${ }^{34}$ Moreover, most of the comparison done focused on very specific and narrow areas, which, when seen cumulatively in their broader context, may produce a different assessment.

The comparison made between Israel and more than a dozen states in the area of the laws of repatriation is a case in point. Of the long list of laws that Rubenstein and Yakobson

\footnotetext{
32 Rubenstein and Yakobson, supra note 20 at 2.

${ }_{33}$ Chaim Gans, A Just Zionism (Oxford and New York: Oxford University Press, 2008) at 71 [Gans, "A Just Zionism"].

${ }^{34}$ Nimer Sultany, Book Review of Israel and the Family of Nations: The Jewish Nation-State and Human Rights, by Alexander Yakobson and Amnon Rubenstein, (2008-2009) 15 Palestine Yearbook of International Law 439. 
categorize as "repatriation laws", none uses religious criteria as the sole criterion for immigration/repatriation. Most of those laws also deal with facilitation rather than the automatic grant of citizenship like the Israeli Law of Return, and some of them are limited to refugees and people under the threat of persecution like the situation in Germany. Most importantly, most of those laws or provisions are part of broader and more flexible immigration policies that may provide more favorable treatment for the immigration of specific linguistic or national minorities, while also providing other avenues for immigration and naturalization. Similarly, almost none of those countries have laws that virtually ban the immigration of a specific group like Israel's Citizenship and Entry to Israel Law 2003. ${ }^{36}$

The third way the nationalists deal with the tension is based on analytical and theoretical engagement with the concepts of democracy and human rights, showing that Israel's definition (and model of democracy) are justified and theoretically coherent. This method is mostly adopted by Ruth Gavison, although she also frequently uses comparative examples in her analysis. In order to minimize the tension, Gavison tries to offer an understanding of the democratic element that could tolerate the combination with the Jewish element. She states that there is a spectrum of hierarchal characteristics of democracy that range from "narrow" characteristics to very "rich" characteristics. ${ }^{37}$ She prefers a narrow definition of democracy that everyone agrees on, which prescribes that the regime in a society should get its legitimacy through the consent of the people under its control through universal suffrage and free and fair elections. ${ }^{38}$ Gavison does not agree that democracy should include

\footnotetext{
35 Rubenstein and Yakobson, supra note 20, 125-135.

${ }^{36}$ The immigration and citizenship laws and policies in Israel will be discussed in chapter IV.

${ }^{37}$ Gavison, "Israel" supra note 15 at 28.

38 Ibid at 29-30.
} 
other components such as a written constitution, constitutional protection of human rights, basic commitment to equality and social justice. ${ }^{39}$ Still she accepts that this narrow and formal understanding entails adopting two sets of values as intrinsic to democracy. The first is the group of human rights that are part of the core conceptual structure of democracy, such as the right to vote and be elected, freedom of speech and freedom of association. The second value is equality, at least formal equality, as embodied by the principle of one person - one vote.

Gavison acknowledges that there is a substantial difference between Jews and nonJews in Israel, but she rejects the proposition that this difference prevents Israel from being democratic. She attributes this difference to the minority status; since the Palestinian minority in Israel is a permanent minority, its alienation is more deep and structural. For her, it is reasonable that part of the population would feel alienated vis-a-vis the regime. This should not be understood as a weakness of democracy. ${ }^{40}$ In Gavison's later writings she seems to have shifted her position on alienation. She argues that reducing the alienation is contingent on accepting the legitimacy of defining Israel as a Jewish state. She asserts that Israel should include the Palestinians in discussions on their integration, but still the sense of "civic partnership" is dependent on the Palestinian citizens declaring that the Jewish people have the right of self-determination in Israel. This means that in order to reduce the alienation, Palestinians should accept Zionism as an ideology. Without this recognition of the legitimacy of the Jewish state, the alienation will grow stronger. ${ }^{41}$ No such demands are made of nonZionist or anti-Zionist Jews; at the same time, their inclusion is not controversial.

\footnotetext{
39 Ibid at 29.

${ }^{40} \mathrm{Ibid}$ at 39.

${ }^{41}$ Gavison, "The Jewish State", supra note 16 at 71.
} 
Gavison concedes and justifies the alienation of the Palestinian citizens, and suggests that it should be reduced within the paradigm of "Jewish and democratic". She adds that this does not mean that Israel should be a state for all of its citizens, because it has a strong Jewish character that manifests itself in the language, religious and national holidays and public culture. ${ }^{42}$ Gavison, however, tries to suggest an approach to the rights of the Palestinian citizens that does not clash with the definition of the state as a Jewish and democratic state.

\subsection{Human Rights, Equality and the Ethnic State}

In trying to provide a justification for the definition and attempting to resolve the tensions it creates, Gavison discusses its impact on the rights of the Palestinian citizens. Her starting point sees maintaining the state's character as a Jewish state as a national interest, and as such, the Palestinian citizens cannot demand that the state ignore its (Jewish) national interests. Since this creates tensions in the society, Gavison suggests that Israel should acknowledge that the needs of Jewish nationalism - which are a national interest in the sense of state interests justify "constraining" the Palestinian citizens. ${ }^{43}$ This "constraining" has implications on a number of levels, including security, land allocation, dispersal of population and education. But while it is permissible to "constrain" the Palestinians, Gavison argues that the state is under an obligation to "try to reduce the suffering" that they incur when there is no conflict with other "public interests". ${ }^{44}$ This reflects an understanding that the interests of the Palestinian minority are not necessarily part of the "public interests" or "state interests" and are often seen as conflicting with them. Interests such as adequate housing, equitable resource allocation and fair immigration policies, which are of concern to the general population, can

\footnotetext{
42 Ibid at 54 .

43 Ibid at 72 .

44 Ibid at 73 .
} 
be trumped by the "public interests" of the majority group. It seems that the "public interests" in this case, as in the case of the national interests, are solely the interests of the Jewish public. The Palestinian citizens, therefore, are not part of the public when it comes to interests. This conception of the "public" is in line with Gavison's idea that the state is the state of the Jewish people and not the state of all its citizens. ${ }^{45}$ If the "public interests", are synonymous with Jewish interests, then what does that say about Gavison's conceptualization of the People in Israel? Is the People comprised of Jews only? Are the Palestinians part of the People, and if so, is it only in a conditional sense where their inclusion is contingent on congruence with the interests of the Jewish majority?

Gavison elaborates on what she means by "constraining". She says that infringing on the "well-being" of the Arabs is justified since without this infringement, the Jews would incur a "deadly" violation of their "important rights." 46 Those "important rights" and interests are the same ones that justified the recognition of the right to self-determination, and they include physical security, the right to self-defense, and "the right of the collective to preserve its uniqueness and its identity and the ability of the individual members to live in a way that gives full expression to their membership in the collective." 47 The argument here is that there is a difference between "violation of interests and well-being" and breach of rights: humans have a

\footnotetext{
45 Notice that in this situation, even if the Palestinians embrace Zionism, as Gavison earlier suggested they must in order to overcome the problem of alienation, they still could be "constrained" since the interests that Gavison talks about here are not related to political views or affiliation. Palestinians as such, regardless of their political beliefs, could be justifiably "constrained" when the Jewish (hegemonic) interests are threatened.

${ }^{46}$ Gavison, "The Jewish State", supra note 16 at 59.

${ }^{47}$ Gavison, "Thoughts", supra note 21 at 135 [translated by author].
} 
basic right to life, security, dignity and national self-determination, but do not have the right to get "everything they want", as Gavison puts it. ${ }^{48}$ She adds that

the Jewish character of the state does not justify in any way discrimination on the basis of religion or nationality, but it allows, encourages, and in some cases it even obligates a nonapologetic emphasis on the special character of the state, and taking measures that will reinforce this character, and encourage its continuity and prosperity in different fields, including the immigration policy, settlement and housing, education, the symbols of the state, its public culture and its language. 49

Gavison further suggests that there should be a close examination of a situation where "state practice is not only undesirable or unpleasant for individuals or specific groups, but amounts to an unjustified violation of the rights of an individual or a group." ${ }^{50}$ In this context, some infringements of "prima facie" rights, if examined in context, do not amount to unjustified violations of rights. Israel, Gavison asserts, acts legitimately when it adopts

practices that do not amount to violations of human rights- whether because those practices do not infringe the right, or because an infringement of the right is justified based on contradiction between the right and important interests, or based on considerations that are internal to the rights discourse itself. ${ }^{51}$

The thrust of Gavison's argument is that the state's definition as a Jewish state and the interest in maintaining the Jewish character justify constraining the welfare and interests of the Palestinian citizens, or even overriding their rights, otherwise Israeli Jews would incur a "deadly" violation of their important rights. It is interesting to examine the language that Gavison uses here. She uses the terms "preferences", "interests", "well-being", "everything they want", to characterize what she sees as the demands of the Palestinians in Israel. Yet, deeper examination of these terms shows that they are not merely marginal issues, but actually reflect human rights protected by international treaties to which Israel is party, and in some

48 Gavison, "The Jewish State", supra note 16 at 59.

49 Ibid at 75 [emphasis added] [translate by author].

${ }^{50}$ Gavison, "Thoughts", supra note 21 at 127.

51 Gavison, "Thoughts", supra note 21 at 128 [translated by author]. 
cases protected by Israeli basic laws. Gavison seems to avoid the conclusion that her interpretation involves human rights violations by renaming rights as interests or well-being, or downgrading them to "prima facie" rights that could be trumped by the right to selfdetermination. ${ }^{52}$

Gavison's framework also does not seem to treat equality as a right. She does not see the fact that the state holds the interests of one national group in higher regard as unequal treatment and therefore a violation of the right to equality. Although Gavison argues for a principle of non-discrimination and civic equality, those should be within the bounds of the interests of the Jewish majority. This, she argues, is not a problem unique to Israel's definition, but is part of the general problem of competing ideas within democracy, that is, the competition between civic equality and majoritarianism. ${ }^{53}$ Gavison addresses this problem by distinguishing between the attachment to the state, which is common among all citizens, and the other attachments of individuals to groups like their co-nationalists or co-religionists. ${ }^{54}$ For the common attachment to the state "to be really equal, we should give it a defined and 'slim' character." and political rights and equal right to receive from the state grants given to all residents and

\footnotetext{
52 But even this renaming of rights still carries with it some indications that the issues at stake here are rights. In liberal thought for example, the proper definition of "right" is debated between two major schools of thought, one that bases the right on interests which is known as the "interest theory of right". Proponents of this approach include, Bentham, MacCormick and Joseph Raz. The other school highlights the importance of will or choice, which is called the "will theory" or "choice theory of right". Proponents of this approach include H.L.A Hart. See The Stanford Encyclopedia of Philosopby (Fall 2011 Edition), "Rights" by Wenar Leif online: <http://plato.stanford.edu/archives/fall2011/entries/rights/>. See also Joseph Raz, The Morality of Freedom (Oxford: Clarendon Press, 1986) at 169. One may question whether Gavison's simple differentiation between rights and interests and preferences is a legitimate one or an artificial one made for the sake "downgrading" rights violations.

53 Ruth Gavison, “The Jews' Right to Statehood: A Defense" (2003) Azure 70 at 94 [Gavison, "Jews' Right to Statehood"]. This article is mainly a translation of the article "The Jewish State: The Principle Justification and the Desirable Character" Still there are many differences between the two texts.

${ }^{54}$ Gavison, "Thoughts", supra note 21 at 172 [translated by author].

55 Ibid [translated by author].
} 
citizens. Citizenship is partnership in the state project." ${ }^{, 56}$ This equality also carries with it equality in the civic obligations which include military service or civic service. ${ }^{57}$ Gavison asserts that the state should recognize the other attachments of the residents and citizens, such as national or ethnic bonds. But the issue here goes beyond the question of merely recognizing national or ethnic bonds, for Gavison insists that Israel is not, and should not be, a multicultural state but a Jewish state. There is clearly a preference here for the Jewish group, and it is not clear whether this preference could be rendered legitimate by the distinguishing it from what she calls "slim" citizenship. This distinction raises many questions: does the state stand at an equal distance from those identities? What is the impact of the defining the state exclusively as a Jewish state rather than a multicultural one? Is the relationship between the state and the individual affected by this distinction? What guarantees do we have that this distinction will not seep into other areas such as civil and political rights? How does this distinction affect the idea of the People? While equal civil and political rights insinuate an idea of an inclusive People that potentially includes all citizens, the recognition and preference of national/ethnic/religious bonds pulls in the opposite direction.

Yakobson and Rubenstein offer a somewhat similar distinction. Following Kymlicka, they distinguish between national identity and civic political identity - a distinction that Gavison accepts and uses to explain her conception of equality. In terms of national identity, they see Israel as the embodiment of the right of national self-determination of the Jewish people. In terms of civic identity, they argue, all citizens in Israel are seen as part of the same

56 Ibid at 172.

57 Ibid at 173. 
People that exercises sovereignty, and therefore Israel is the state of its citizens. ${ }^{58}$ But this assertion ignores the fact that Israel's ethno/religious definition has implications for the relation between the state and the individual, and the relation between the state and the dominant majority. In this case, there is no equality between the groups. Kymlicka, in contrast, calls for equality between homeland groups in the conclusion of his book from which Yakobson and Rubenstein borrow the distinction. ${ }^{59}$

\subsection{Conclusion}

The nationalist approach sees the nation and its self-determination as the highest objectives, but at the same time tries to adhere to the basic tenets of a certain understanding of democracy, liberalism and human rights. This is usually done through adopting a set of distinctions: one between the People, which is supposed to be a broad category that encompasses all Israeli citizens who together hold sovereignty, and the nation, which is the group that exercises its self-determination in the state, which in the case of Israel is the Jewish nation, which encompasses all Jews (wherever they are); and another distinction between attachment to the state, which is common among all citizens (slim citizenship), and the other attachments of individuals to national or religious groups which the state should recognize.

But in these attempts to resolve the tension between the Jewish and the democratic elements, the Jewish element seems to prevail. This is evident on a number of levels. First, it is evident in the narrow definition of democracy that is adopted. Second, it is also evident in the narrow definition of citizenship. This narrow definition of citizenship is done in a manner that

58 Rubenstein and Yakobson, supra note 28 at 241-242. The reference here is to the Hebrew edition where the authors explicitly refer to Kymlicka. It should be noted that the English edition is not an identical translation of the Hebrew edition, and there are some differences.

${ }^{59}$ Will Kymlicka, Multicultural Citizenship: A Liberal Theory of Minority Rights (Oxford: Clarendon Press, 1995) at 194. 
gives more power to the majority group, making equality very hard to achieve. Third, the prevalence of the Jewish element is evident in the strong emphasis on preferring the interests of the Jewish collective even if it comes at the expense of the rights (renamed interests or welfare) of the non-Jewish citizens. Fourth, it is evident in the narrow approach to equality, which makes equality subordinate to the interests of the Jewish majority and ignores social, historic and economic realities.

The nationalist approach tolerates the non-Jewish citizen, but does not see him/her as a full partner in that he/she does not partake in the national ethos of the state. As such, the minority is seen as a threat and therefore should be kept a minority in order to preserve the Jewish character of the state. Any growth in the minority is seen as a threat to the stability of the constitutional order because the minority, through political participation and voting, will be able to challenge the Jewish definition of the state. This implies that actual political power should always be in the hands of the Jewish citizens. At the same time, this approach satisfies the basic demands of formal democracy in terms of civil and political rights, but this adherence to formal democratic values seems to be conditional. For example, the Palestinian citizens are granted the right to vote, but in order to limit the influence of this vote on the political system, they should stay a minority and their political participation should be curtailed. It is not surprising therefore that Gavison sometimes uses the term "Jewish sovereignty" when she discusses the relationship between the Palestinian citizens and the state. ${ }^{60}$ These observations raise the question of whether non-Jewish citizens are part of the People.

${ }^{60}$ Gavison, “Jews' Right to Statehood”, supra note 53 at 91. 
Another tendency that can be discerned in the writings of the nationalists is their tendency to use the formula of "two states for two nations" in order to justify discriminatory laws or policies. They assume that the Palestinian citizens in Israel will be able to enjoy the rights that they are denied in Israel - such as equitable immigration policy and the right to self-determination - in the state that may be created in the OPT. While this tendency is problematic on a number of levels, ${ }^{61}$ it is also an indication of who is conceived of as the People.

International legitimacy plays an important role in the nationalist approach. The focus on international recognition of some elements of Israel's constitutional definition is problematic. This international recognition, for example, relies on the Balfour Declaration and the articles of the Palestine Mandate, ignoring the many critiques of the Mandate system which view it as a reproduction of colonialism. ${ }^{62}$ Even the reliance on UNGA Resolution 181 is problematic in terms of constitutionalism since it reflects the will of the states that voted in favor of the resolution, and ignores the will of the majority of people who resided in the relevant area. There is an attempt here to substitute international recognition for the consent of the governed - one of the fundamental principles of democracy and constitutionalism.

${ }^{61}$ First, it assumes that the citizen has to emigrate elsewhere in order to enjoy the rights that the state secures for the citizens of the majority group. This becomes more problematic when the immigration in this case is not repatriation, since the Palestinian citizens in Israel did not originate from the OPT, thus treating a national homeland minority as an immigrant minority. Second, since there is no Palestinian state, this justification is based on a speculation about the future rather than on facts. Third, the creation of the Palestinian state, that according to this thesis would give those rights, is thwarted by the occupation by Israel. Fourth, there is no guarantee that a Palestinian state -if ever created- would give those rights to the Palestinian citizens of Israel. The assumed future Palestinian state is under no obligation to do so. Fifth, it assumes that such a state will be an ethnic nation state like Israel that emphasizes ethnic citizenship. Sixth, equality should be measured in each state; inequality in one state cannot be offset by inequality in another.

62 Anthony Anghie, Imperialism, Sovereignty and the Making of International Law (Cambridge: Cambridge University Press, 2004) at 115-194. 
This leaves us with the unresolved question: who exactly is the People that exercises sovereignty? While Rubenstein and Yakobson actively state it includes all citizens, and Gavison intimates it is those who have the "slim citizenship" and attachment to the state, the nationalists' emphasis on the preservation of a Jewish majority, self-determination, and Jewish interests make the picture more complicated. There is ambiguity about who is included in the sovereign People.

\section{The Pragmatic Approach}

The opinions discussed in this part are labeled pragmatic because they base normative theoretical models on existing realities in such a way that the theory serves to justify the existing reality and not to critique it. In essence, the approaches are justificatory and they carry the risk of perpetuating existing inequities. Two authors will be examined in this part, Sami Smooha and Aharon Barak. While Smooha's work will be examined briefly, I will focus more on Barak because of the importance of his approach and his emphasis on constitutional interpretation.

\subsection{Ethnic Democracy}

Sami Smooha's developed the "Ethnic Democracy" model in the late 1980s and early 1990s as a descriptive model with critical potential. Critics argue that the model has turned into a tool of legitimation despite the fact that Smooha insists that it is a scientific model without normative dimensions. ${ }^{63}$ Smooha defines ethnic democracy as "a democratic political

63 Smooha has elaborated on the model in several articles. See, Sammy Smooha, "Minority Status in Ethnic Democracy: the Status of the Arab Minority in Israel" (1990) 13:3 Ethnic and Racial Studies 389; Sammy Smooha, "Ethnic Democracy: Israel as an Archetype" (1997) 2:2 Israel Studies 198; Sammy Smooha, "The Regime of the State of Israel: Civil Democracy, Non-Democracy, or Ethnic Democracy?" (in Hebrew) (2000) Sociologia Yisraelit 2: 2: 565; Sammy Smooha "The Model of Ethnic Democracy: Israel as a Jewish and Democratic State" (2002) 8:4 Nations and Nationalism 475; Sammy Smooha, "The Model of Ethnic 
system that combines the extension of civil and political rights to permanent residents who wish to be citizens with the bestowal of a favored status on the majority group." ${ }^{\prime 64}$ It entails an institutionalization of the dominance of one ethnic group, and civil and political rights for all, creating ambiguities, contradictions, conflicts, and sometimes political instability. The cornerstone of the state for this model is the ethnic nation, not the citizenry. The majority, which sees the state as belonging to it and as a tool to advance its interests, is in an almost constant state of conflict or tension with the minority. The minority is viewed suspiciously and does not enjoy full equality. But in this model, Smooha insists, "democracy is real and not a façade", ${ }^{65}$ since it allows the disadvantaged minority to struggle to improve its situation without fear of repression. ${ }^{66}$

Smooha is aware that this model suffers from many flaws, lack of civil and political equality being the fundamental one. Asserting that democracy should be seen on a continuum, he qualifies ethnic democracy as a "diminished democracy". But Smooha insists that ethnic democracy is a democracy, mainly because it shares more with civic democracy than with nondemocracy, and because it meets the minimal and procedural definitions of democracy such as free elections, universal suffrage, and respect for civil and political rights. ${ }^{67}$ It also offers recognition of the collective rights of minority groups, but Smooha concedes that this is done in the manner of "separate but not so equal". 68

Democracy" in Sammy Smooha \& Priit Jarve, eds, The Fate of Etbnic Democracy in Post-Communist Europe (Budapest: Open Society Foundation, 2005) 5 [Smooha, "The Model"].

${ }^{64}$ Smooha, "The Model", ibid at 21.

${ }^{65}$ Ibid at 22 .

${ }^{66} \mathrm{Ibid}$ at 22

${ }^{67}$ Ibid at 8 .

${ }^{68}$ Ibid at 23. 
The model has been criticized by many scholars on a number of grounds. The main attack centers on calling it a democracy when it is not genuinely democratic. The title of democracy, it is argued, bestows on it an air of legitimacy that it does not deserve, and thus perpetuates reality instead of criticizing it. ${ }^{69}$ Azmi Bishara specifically censures Smooha for adopting the status quo as a model instead of criticizing it to advance the causes of democracy and social change. ${ }^{70}$ Aeyal Gross, while criticizing the minimal and formal definition Smooha uses, questioned whether Israel qualifies as a democracy according to Smooha's own definition. ${ }^{71}$ Both Ahmad Sa'di and Gross express reservations about the adequacy of using opinion polls to provide empirical evidence about this model, in addition to questioning the methodology of those polls. ${ }^{72}$

To sum up, given the fact that the model is built on the idea of living with the contradiction and tension rather than resolving it, and given that it deals more with a theoretical model without concrete emphasis on the scope of rights besides acknowledging their inequality, this model avoids dealing with important aspects of the tension in the Jewish and democratic definition. While there is no discussion of the People, it seems that despite granting citizenship rights and civil and political rights to minorities, only those who belong to

\footnotetext{
${ }^{69}$ Azmi Bishara, "The Sovereignty Process is Not Yet Complete" in David Joseph, ed, The State of Israel: Between Judaism and Democracy Jerusalem: Israeli Democracy Institute, 2003) 379 [Bishara, "The Sovereignty"]; As'ad Ghanem, Nadim Rouhana \& Oren Yiftachel, "Questioning 'Ethnic Democracy': A Response to Sammy Smooha" (1998) 3:2 Israel Studies 253; Ahmad Sa'di, "Israel as Ethnic Democracy: What are the Implications for the Palestinian Minority?" (2000) 22:1 Arab Studies Quarterly 25 [Sa'di, "Israel"]; Aeyal Gross, "Democracy, Ethnicity and Constitutionalism in Israel: Between The Jewish State' and 'the Democratic State"' (in Hebrew) (2000) Sotsyologia Yesraeilit 2:2 647 [Gross, "Democracy"]; Amal Jamal, "Beyond 'Ethnic Democracy': State Structure, Multicultural Conflict and Differentiated Citizenship in Israel" (2002) 24:3 New Political Science 411.

${ }^{70}$ Bishara, "The Sovereignty", supra note 69.

${ }^{71}$ Gross, "Democracy", supra note 69.

72 Sa'di, "Israel", supra note 69; ibid.
} 
the dominant group can truly be seen as the sovereign People, for the ethnic nation is the cornerstone of the state and not all citizens.

\subsection{Interpretation and Abstraction: Abaron Barak}

As the former Chief Justice of the Supreme Court, Barak was at the forefront of designing the judicial approach that prevails today to the Jewish and democratic definition. ${ }^{73}$ His approach reflects, to a large extent, the prevalent approach among the Justices of the Supreme Court - at least among those seen as in the "liberal stream." Barak's starting point is that the values of the state as a Jewish and democratic state are central to the Israeli legal system. They have a "normative constitutional status that is above the law." "74 This formula, Barak emphasizes, "has a heavy and important normative load." 75 The values are also central to the institutions of governance as well as the Israeli legal system in its totality.

Barak acknowledges that the Jewish and democratic values could be in conflict, for they reflect ideals, and each ideal has its own internal conflicts and conflicts with other ideals. It is therefore important to find an interpretation where conflicting values supplement and synthesize with one another, and if that is impossible to do, then the last resort is to prefer

\footnotetext{
73 Aharon Barak presided over the Supreme Court of Israel for more than 11 years, and served as a Supreme Court Justice for about 29 years, including his presidency. Although he is seen as liberal, critical assessment of his decisions, especially his decisions regarding the Occupied Palestinian Territory would show otherwise. See Nimer Sultany, "The Legacy of Justice Aharon Barak: A Critical Review" (2007) 48 Harvard International law Journal 83. See also, Hassan Jabareen, "Ignoring the "Other", Book review of $A$ Judge in a Democratic Society by Aharon Barak, (2005) 14 Adalah's Newsletter online: http://www.adalah.org/newsletter/eng/jun05/rev.pdf.

${ }^{74}$ Aharon Barak, $A$ Judge in a Democratic Society (In Hebrew) Jerusalem: Nevo, 2004) at 83 [Barak, "A Judge"] [translate by author]. Barak's approach of this question extends over hundreds of pages dispersed in books and articles, interviews and lectures. Most of them are rather repetitive with slight changes. His book $A$ Judge in a Democratic Society is the most recent publication in which he tackles this issue, and where he repeats -sometimes verbatim- the same ideas, with slight additions and adjustments. In this book, he also discusses questions that he dealt with as a judge. See geneally Aharon Barak, "The Constitutional Revolution: Protected Basic Rights" (in Hebrew) (1992) 1 Mishpat o Mimshal 9; Aharon Barak, "Protected Human Rights: Scope and Limitations" (in Hebrew) (1993) 1 Mishpat o Mimshat 253; Aharon Barak, "The Role of the Supreme Court in a Democracy" (1998) 3:2 Israel Studies 2; Aharon Barak, "The State of Israel as a Jewish and Democratic State" (in Hebrew) (2000) 24 Iyunei Mishpat 1.

75 Barak, "A Judge", supra note 74 at 83 [translated by author].
} 
one value over the other. ${ }^{76}$ Barak does so by examining the meanings of both values understood at a high level of abstraction to come up with the best synthesis.

For Barak, a Jewish state is the state of the Jewish people; it reflects the natural right of the Jewish people to a state. This approach combines two perspectives, a Zionist one and a traditional hilkhatic one that is derived from religious heritage. Both perspectives are closely related and sometimes overlap. The Zionist perspective primarily means, as he puts it, "the vision that Israel is the national home of each and every Jew."77 At the heart of this understanding is the right of every Jew to immigrate to Israel according to the Law of Return which he sees as one of the most fundamental laws of the state that should be transformed into a basic law. ${ }^{78}$ In Israel, "and nowhere else", Barak says, "all parts of the Jewish people should be ingathered."79 This perspective also mandates that the main language should be Hebrew, that the main holidays should reflect the state's national revival, and the use of the existing flag and anthem. ${ }^{80}$ The Zionist perspective also means that the Jewish state is a "state that redeems state land for Jewish settlement" ${ }^{\prime \prime 1}$ and that promotes Jewish settlement in its "fields, cities and towns". The traditional religious perspective is derived from the religious tradition (balakba), which includes Jewish law and Jewish heritage. Accordingly, Jewish law should play an important role in the Jewish state, and this state should respect the Sabbath. ${ }^{82}$

76 Ibid at 87.

77 Ibid at 88 [translated by author].

${ }^{78}$ Ibid.

79 Ibid at 83-84 [translated by author].

${ }^{80} \mathrm{Ibid}$ at $87-88$.

${ }^{81}$ Aharon Barak, "The Values of Israel as a Jewish and Democratic State" (in Hebrew) (18 June 2002) online: <http://www.news1.co.il/archive/003-d-1202-00.html?tag=21-53-48\%23ptext1767> [Barak, "The Values"] [translated by author].

82 Barak, "A Judge", supra note 74 at $88-89$. 
Barak sometimes adds that the Jewish state is one where matters of marriage and divorce among Jews are decided according to the Torab. ${ }^{83}$

As for democracy, Barak's definition rests on two bases: first, the sovereignty of the People, which is the formal part of democracy. This translates into majority rule, and an elected legislature. The second basis is the rule of values that are essential for democracy, such as the separation of powers, the rule of law, independence of the judiciary, human rights, and values such as justice, ethics and good faith. This is the substantive aspect of democracy. ${ }^{84}$ Quoting Dworkin, Barak asserts that democracy is a combination of both formal and substantive perspectives that should be balanced and reconciled. He distances himself from Gavison's restrictive understanding of democracy. ${ }^{85} \mathrm{He}$ adds that not every infringement on these democratic principles negates the democratic character of the state. Like Smooha, democracy for him lies on a continuum, and some democracies are better and stronger than others, but they are still democracies as long as core democratic principles are maintained. ${ }^{86}$

The individual, Barak asserts, is at the core of the democratic state. The individual joined other individuals to form the People and to exercise sovereignty through the creation of the state, as Barak explains in a Rousseauian-style social contract theory. ${ }^{87}$ Barak emphasizes the principle of the sovereignty of the People that is exercised in two ways. First, through the creation of a constitution that entrenches democracy, and that prescribes the fundamental values of the regime and main arrangements for governance. The second way is through periodic elections where the People elects its representatives. The latter expression of

\footnotetext{
${ }^{83}$ Barak, "The Values", supra note 81.

${ }^{84}$ Barak, "A Judge", supra note 74 at 91.

${ }^{85}$ Ibid at 92.

${ }^{86}$ Ibid at $92-93$.

87 Ibid at 97.
} 
sovereignty (elections) is subordinate to, or constrained by, the former (the constitution). This could be derived from the concept of sovereignty itself - the People have the right to constrain their sovereignty if they wish to do so, or using Kelsen's basic norm (grundnorm), the will of the People to constitute a constitution that would be the highest legal norm in the state could be seen as the grundnorm of the constitutional democracy. ${ }^{88}$ The constituent body, in this case, the Knesset, is also constrained by democracy. A constitutional amendment cannot eliminate democracy. Such an amendment will be seen as an unconstitutional constitutional amendment. ${ }^{89}$ Similarly, a democracy is under no obligation to allow the participation of a party or individuals in the elections if they wish to eliminate it. ${ }^{90}$ Barak's understanding of the People on an abstract level reflects a classic liberal approach that includes all those who are citizens and can vote in the elections. What is left of this understanding when the Jewish element is introduced?

\subsubsection{Reconciling the Jewish and the Democratic Elements}

Barak's point of departure is that the two elements of the definition can and should live together in harmony, and this can be achieved through interpretation by focusing on the uniting and common elements while trying to prevent contradictions. ${ }^{91}$ This can be done by adopting a non-monolithic approach to democracy and Judaism, while at the same time avoiding as much as possible the adoption of values that create conflict and contradiction. ${ }^{92}$ The interpreter, Barak says, "should take from each of the Zionist, bilkbatic and democratic sources the values, perspectives and principles that are consistent with the values, perspectives

\footnotetext{
88 Ibid at $95-96$.

89 Ibid at 99.

90 Ibid at 101.

${ }^{91}$ Ibid at 157.

92 Ibid at 158.
} 
and principles in the other sources." ${ }^{, 93}$ When the conflict is obvious, the interpretation should rely on a high level of abstraction to achieve values that are consistent. ${ }^{94}$ If there is a real conflict between both values, the solution is to act reasonably and rationally "to choose the option that is more consistent than any other option with the fundamental perspectives of the society in its totality." 95 Barak adds that the interpretation should take into consideration values such as the ones in section one of the basic laws, ${ }^{96}$ and the fact that "amongst us lives a significant minority whose values are not Jewish - not Zionist and not traditional". ${ }^{97}$

Barak believes that a Jewish and democratic state is the "state of all its citizens" since it upholds the principle of equality amongst its citizens, which he sees as the normal meaning of the term "state of all its citizens". ${ }^{98}$ On the other hand, he asserts that if the meaning of the term "state of all its citizens" goes beyond the aspiration for equality to question the rationale underlying the creation of the state, and does not recognize that Israel is the state of the Jewish people, then this is not acceptable. ${ }^{99}$ This position reflects the tension in Barak's conceptualization of the People and the departure from the classic liberal conception, for he does not explain how the state of the Jewish people would be the state of all its citizens when there is a

93 Aharon Barak, "The Values of the State of Israel as a Jewish and Democratic State" in Chaim H. Cohen \& Yitzhak Zamir, eds, Abaron Barak: Selected Essays (in Hebrew) Oerusalem: Nevo, 2000) 445, at 452 [Barak, "Values of the State"] [translated by author].

94 Ibid at 453.

${ }^{5}$ Ariel L. Bendor \& Zeev Segal, The Hat Maker: Discussions with Justice Aharon Barak (in Hebrew) (Or Yehuda: Kinneret Zmora-Bitan Dvir Publishing House Ltd., 2009) at 195 [translated by author]. See also Aharon Barak, Interpretation in Law (in Hebrew) Jerusalem: Nevo Publishing, 1994) vol 3 at 345. In this version, he refers to the "perspectives of the enlightened public". Barak abandoned this term after he was accused of elitism since many understood the "enlightened public" to exclude Arabs, Mizrabi Jews and religious Jews.

96 Section 1 in both Basic Laws prescribes that "[f]undamental human rights in Israel are founded upon recognition of the value of the human being, the sanctity of human life, and the principle that all persons are free; these rights shall be upheld in the spirit of the principles set forth in the Declaration of the Establishment of the State of Israel."

97 Barak, "Values of the State", supra note 93 at 454 [translated by author].

${ }^{98}$ Barak, "A Judge", supra note 74 at 160.

99 Ibid at 161. 
significant non-Jewish indigenous minority. He also does not explain how that would impact members of the national minority when the state defines itself exclusively as the state of a different group. Nor does he explain how equality could be reconciled with the long list of Zionist ideals that favour Jews.

To bolster his argument that the Jewish state can also be the state of all its citizens, Barak asks whether the Law of Return can be reconciled with the principle of equality. The answer that he derives from Israel's raison d'etre and from "Zionism, heritage and democracy" is that Israel was created to be the national homeland of the Jewish People, and "the fact that a nation state opens its gates and gives a special key to enter for the members of that nation does not constitute discrimination against other nations." ${ }^{100}$ Citing Rubenstein and Yakobson, he says that such policies are globally acceptable. ${ }^{101}$ In addition, there is no discrimination in this policy because there is a relevant difference: non-Jews belong to other nations. His treatment of this argument does not deal with the many counter-arguments raised against this law, one of which is that it entirely disregards the interests of the Palestinian citizens in devising an immigration policy, which raises questions about his commitment to equality. ${ }^{102}$

Similarly, Barak's discussion of the restrictions on the right to participate in elections leaves many questions unanswered. He justifies restrictions arguing that a democratic state should protect its democratic regime and is therefore justified in banning anti-democratic parties from participating. Democracy should be protected because it is the tool for translating the sovereignty of the People into action, and the elimination of democracy infringes on this sovereignty. He then adds that this is also the rule regarding Israel's character as a Jewish state

100 Ibid [translated by author].

${ }^{101}$ He also cites Yuval Shteinitz, "Democracy: The Liberal Threat" (in Hebrew) (2001) 17 Mehkari Mishpat 91.

102 Immigration policy and the Law of Return will be discussed in detail in Chapter IV. 
because this character or nature is the "axiom of the state". ${ }^{103}$ Barak does not offer any explanation for restricting the right of political participation based on the negation of the Jewish character of the state except asserting that "this is a fundamental principle of our law and system". ${ }^{104}$ So while the disqualification of anti-democratic parties is justified as a reasonable constraint in order to protect democracy, which is an argument that is internal to democracy, banning a party from participation because it rejects the Jewish character is an infringement on democracy that is justified only by the wish to preserve the Jewish nature, that is, an argument that is external to democracy. This exacerbates the tension in Barak's approach: while he insists that the sovereignty of the People is at the heart of the constitutional order, and is organically linked with democracy, the Jewish definition (the idea that Israel is the state of the Jewish people) comes to constrain this sovereignty. These constraints come in a number of ways. In addition to restrictions on participation in elections, Barak believes the Jewish and democratic definition of the state cannot be changed through the Knesset even if a majority supports such a move. Such an amendment will be unconstitutional, and the Knesset lacks the power to do so because the authorization for the Knesset to adopt a constitution was intended to express the fundamental values of the Israeli society as set out in the Declaration of Independence. Barak believes that democracy and the Jewish nature of the state are supra-constitutional principles that the constitution (basic laws) should be subject to. ${ }^{105}$ This position has far-reaching implications for democracy and constitutionalism, and will be discussed at length in chapter VI. It also has implications for the conceptualization of the People.

${ }^{103}$ Barak, "A Judge", supra note 74 at 101 [translated by author].

104 Ibid [translated by author].

${ }^{105}$ Bendor \& Segal, supra note 95 at 144-145. 


\subsection{Summary}

Barak adopts an interpretative approach that relies on abstraction to avoid direct engagement. He avoids in-depth analysis of the hard questions as in the case of his analysis of the Law of Return. Instead, Barak is satisfied with abstract statements supported by strong rhetoric. Avoidance, then, is one strategy. The second one is leaps of faith such as the ones he makes when he justifies the banning of participation of parties that do not recognize the Jewish character of the state as part of protecting democracy. Another leap of faith involves the discussion of the concept of the "state of all its citizens" and equality. This creates tensions and contradictions in his approach. ${ }^{106}$ These tensions affect Barak's conceptualization of the People. On the one hand, he is very clear about the People's status as the sovereign that holds constituent power and exercises these powers through democracy, and he clearly relates the People and exercising sovereignty to elections, thus all Israeli citizens are included in the People. On the other hand his emphasis on particularistic Zionist ideals on almost all policy levels, and his justification of constraints on political participation and immigration imply a more restrictive view of the People and who is included in it. In this sense, his position is close to the nationalist approach in that it presents an open understanding of the People as the citizenry, but in reality defends and justifies a view that leads to an exclusionary conception of the People, or at least a conception that involves a hierarchy among different groups. The main difference is that Barak avoids engagement with the contradictions while the nationalists

106 The contradictions lead sometimes to statements that are hard to reconcile with the universalist view he presents, such as his statement that a Jewish state redeems state land for Jewish settlement. See Barak, "The Values", supra note 81. Redeems from whom? According to traditional Zionist terminology, redeeming the land is acquiring it from non-Jewish (mostly Palestinian) owners. Should the state set this as a goal? And if the land is already state land, how could the state be "redeeming" it? How could the very use of the loaded term "redeem", which insinuates that land ownership by Palestinians is an undesirable aberration, be reconciled with equality? 
use different devices to deal with them. This gives him more room to assert commitments to democracy and liberal principles.

\section{The Liberal Approaches}

A number of academics have tackled Israel's definition as a Jewish and democratic state from a liberal point of view. The literature is as diverse as the many strands of liberalism. In this part, I will map some of the main liberal arguments made regarding the definition and what they could tell us about the idea of the People in in the context of the definition.

\subsection{Classic Liberalism}

Joseph Raz's position exemplifies the position of a classic liberal. In a succinct commentary on an article by Aharon Barak, Raz examines the morality of the possible interpretations of the meaning of the "Jewish and democratic" definition. His starting point is that states have no value in themselves; their value hinges on them being "good homes for their inhabitants." ${ }^{, 107}$ Based on this criterion, Raz examines four possible options for interpreting the terms "Jewish and democratic". The first option means that the Jewish religion has special privileges in Israel. The second interprets "Jewish and democratic" as giving Jews special standing in the state and rights that other inhabitants do not have. $\mathrm{He}$ acknowledges that this is the situation to a certain extent. The third approach entails upholding uniquely Jewish values, as opposed to universal values, that is, ethnic or national values. Raz rejects these three options as immoral. ${ }^{108}$

${ }^{107}$ Joseph Raz, "Commentary: Against the Idea of a Jewish State" in Michael Walzer, Menachem Lorberbaum \& Noam J. Zohar, eds, The Jewish Political Tradition (New Haven \& London: Yale University Press, 2000) vol 2 at 509. 108 Ibid at 510 . 
In the fourth option he focuses mostly on Barak's interpretive approach which he understands as adopting universal values but implementing them in the form they took in Jewish history. Raz comments that it is an inevitable and a universal phenomenon that universal values take local forms when they are implemented locally. All states that espouse those universal values essentially do that automatically and rationally, without the need to enact or declare the local character. As such, the United States does not declare itself an American state. Raz therefore concludes that the Jewish definition serves a different objective; for "it is not an appeal to the practices and institutions that grew in Israel over the years", 109 but an appeal to the traditions of the Jewish people throughout history revived in Israel through deliberate efforts. As such, he also rejects this interpretation as immoral. ${ }^{110}$

Since all of these understandings are immoral, Raz sees Barak's interpretation, where he interprets the Jewish values of the state as universal values such as social justice, equity, and sanctity of life, as an attempt to empty the law of its content in order to make an immoral law morally acceptable. ${ }^{111} \mathrm{Raz}$ sees this interpretation as redundant. If indeed this is the meaning of a Jewish state, Raz argues, France could also be one since it adopts similar values. At the time of writing (late 1990s), he saw this interpretation as harmless although he would like to see it dispensed with since it invited misinterpretation. Given that all interpretations of "Jewish and democratic" are immoral in Raz's view, and an interpretation expunging its

\footnotetext{
109 Ibid at 511.

110 Ibid at 509, 511-512.

111 It should be noted here that Raz's discussion of Barak's approach is based mostly on an article by Barak from 1992 when the Basic Laws were first enacted. Barak's interpretation of the terms Jewish and democratic was still developing, and it focused mostly on the universal values renamed Jewish values, and some particular statements such as the importance of the Law of Return. Barak's position has developed since then to the interpretation explained in the previous section. His current position, which emphasizes Zionism and the Zionist perspective, seems to have been precipitated by the Ka'dan case (HCJ 6698/96 'Adel Ka'dan v. Land Administration of Israel (2000), IsrSC 54 (1) 258) which was decided in March 2000. The petition was submitted in 1995. This assertion is based solely on a review of his publications and tracing the changes in them.
} 
content is the only acceptable one, it follows that the Israeli basic laws are highly problematic, especially since it will be hard to avoid "some intellectual dishonesty or untruths" in the process of interpreting them. ${ }^{112}$ This seems to be a self-fulfilling prophecy. Since Raz wrote these words, the "Jewish and democratic" formula has been used by the government to justify laws that constrain Palestinian citizens.

The second problem that Raz sees, which is his main objection to the definition, is the exclusion inherent in it. He argues that the state cannot be the state or the home of its people who are not Jewish. ${ }^{113}$ He concludes by saying that morally speaking, a state is the home of all its inhabitants, with no second-class citizenship, nor tolerated minority status. The ethnic definition, Raz asserts, "cultivates racism, hatred, and the inability of part of their population to regard themselves as equal citizens in their homeland." 114 The People in this sense cannot be fragmented into hierarchical relations - a view which the nationalists and the pragmatists seem to implicitly accept. ${ }^{115}$

Ronald Dworkin expresses similar views. He argues that the discriminatory character of Israel's policies, which is a reflection of the state's Jewish character, is indefensible and undemocratic. Dworkin does not accept the self-determination argument. Citing differences in Jewish histories, cultures and languages, Dworkin does not believe that Jews constitute a nation as a political unit. Speaking specifically in response to Chaim Gans (see below), he does

$112 \mathrm{Raz}$, supra note 107 at $509,513$.

113 Ibid.

114 Ibid at 509, 514. It is important to note that $\operatorname{Raz}$ is not opposed to the idea of special cultural groups maintaining their own culture and engaging in activities derived from their cultures. As a proponent of pluralism and multiculturalism, he promotes this approach which is based on equal membership in political society. See Joseph Raz, "Multiculturalism" (1998) 11:3 Ratio Juris 193.

115 It is ironic that many of the proponents of the nationalist approach rely heavily on Raz's article (co-authored with Avishai Margalit) or his approach to perfectionist liberalism to justify Israel's definition as a Jewish state based on the principle of national self-determination. See Joseph Raz \& Avishai Margalit, "National SelfDetermination" (1990) 87:9 The Journal of Philosophy 459. 
not think that there are many people who identify as Jews who also have an interest in preserving the culture through self-determination. Dworkin suggests that the right to selfdetermination is not sufficient to justify exercising dominion over Israel's non-Jewish population because Israel owes equal respect and concern to its Arab minority. He also criticizes Israel's immigration policy because it shows disrespect to a significant portion of the citizens. For Dworkin, therefore, the People encompasses at least all citizens who should be treated with equal respect and concern, which is not the case in Israel. ${ }^{116}$

\subsection{Liberal Nationalism}

In the quest to provide a conceptual justification for Zionism and for Israel's definition, a number of scholars have adopted approaches that combine liberalism and nationalism, mostly ethnic nationalism. ${ }^{117}$ Liberal nationalism is a broad and nebulous category and writers explored under the nationalist approach would normally try to situate themselves in it since they try to fit their positions or models within liberalism.

One of the leading theorists associated with the idea of liberal nationalism, and who defends Israel's definition based on this idea, is Yael Tamir. ${ }^{118}$ Tamir starts from the premise

116 Ronald Dworkin, "Democracy and Religion: America and Israel" (14 September 2009), online: $<$ http://www.youtube.com/watch? $\mathrm{v}=$ AU9kU1Y-xUY $>$.

117 In addition to the writers discussed here, many others, such as Ilan Saban, Daphne Barak-Erez, Mordechai Kremintzer, could also be categorized as liberal nationalist, or somewhere between the liberal nationalism and Smooha's ethnic democracy. See, Ilan Saban, "Up to the Limit of the Zionist Paradigm" in Ozacky-Lazar et al eds, Seven Roads: Theoretical Options for the Status of the Arabs in Israel (in Hebrew) (Givat Haviva: The Jewish-Arab Center for Peace, 1999), 79; Ilan Saban, "Minority Rights in Deeply Divided Societies: A Framework for Analysis and the Case of the Arab-Palestinian Minority in Israel" (2004) 36 New York University Journal of International Law \& Politics 885; Daphne Barak-Erez, "Israel: Citizenship and Immigration Law in the Vise of Security, Nationality, and Human Rights" (2008) 6 International Journal of Constitutional Law 184; Mordechai Kremintzer, "The Image of the State of Israel as a Jewish and Democratic State" in Aviezer Ravitzky \& Ydidia Z. Stern, eds, The Jewishness of Israel (in Hebrew) Jerusalem: Israel Democracy Institute, 2007) 395.

${ }^{118}$ It should be noted that the idea of liberal nationalism has attracted a lot of criticism. See for example Arash Abizadeh, "Liberal Nationalist Versus Postnational Social Integration: On the Nation's Ethno-Cultural Particularity and 'Concreteness"' (2004) 10:3 Nations and Nationalism 231. 
that cultural-national neutrality is unrealistic and theoretically inconsistent. ${ }^{119}$ As a democracy, she explains, Israel should have the right to define itself as Jewish if this reflects the preferences of the majority of its citizens, similar to its right to determine its economic and social policies according to the preferences of the majority. ${ }^{120}$ Majoritarianism means that the Jewish culture is the dominant culture. That Israel clearly and openly self-defines as a Jewish state, Tamir states, should be to Israel's advantage. Israel has a cultural national bias and it clearly acknowledges it, which allows those harmed, mainly, its Palestinian citizens, to explain their grievances. ${ }^{121}$ But the state is under no obligation to alleviate the grievances. Majoritarinism is part of the democratic game, which always produces winners and losers. Minorities will always be at a disadvantage since their ability to influence state institutions is limited. This reality does not violate democratic principles. As long as citizens are treated equally, Tamir asserts, democracy does not require, and should not require, the equalization of the influence of the majority and the minority. ${ }^{122}$ The Palestinian citizens in Israel, therefore, "are bound to feel excluded."123 She sees this estrangement as structural; it will only disappear if the Palestinians assimilate into the majority. But she does not explain what assimilation of the Palestinians in this case means given that the official definition of Jewish is a religious one. She nevertheless emphasizes that the Jewish character of the state is subject to democratic principles, and the majority should be allowed to change it. The Jewishness of the state

\footnotetext{
119 Yael Tamir, "A Jewish Democratic State" in Michael Walzer, Menachem Lorberbaum \& Noam J. Zohar, eds. The Jewish Political Tradition (New Haven \& London: Yale University Press, 2000) vol 2518 at 519 [Tamir, "A Jewish Democratic"].

$120 \mathrm{Ibid}$ at 521.

121 Ibid at 519 .

$122 \mathrm{Ibid}$ at 520 .

123 Ibid.
} 
therefore should be limited by the democratic nature. As a result, she sees the laws limiting participation in elections as unjustified. ${ }^{124}$

The thrust of Tamir's argument is that defining Israel as a Jewish state is justified as long as it reflects the preferences of the majority. Is it then a mere description of reality, or does it have normative implications? This is unclear from Tamir's analysis. It seems that she sees the Jewish character as a description of the state which plays an interpretive role in translating "the universal into local terms." 125 This point was addressed specifically by Raz who says that all states essentially do that without declaring their essence or character. What if the local context is divided (even if there is a clear majority)? What does the enactment of one local context (Jewish) and the exclusion of the other (Palestinian) mean? Essentially, that means that although the Jewish character is presented as descriptive, it is in reality normative in that it prefers one local context (and citizens) and negates the other. Concerning the Law of Return, Tamir concedes that the law violates the rights of national minorities because it only benefits the majority, and therefore it is only justified if the Palestinians in Israel would have somewhere else to emigrate to be part of the majority. ${ }^{126}$ In the same vein, she notes that the fact that "liberal neutrality places the state at an equal distance from all its citizens, reassuring them all that the state will treat them with equal concern and respect" makes it hard for the state to be a "home" for anyone. ${ }^{127}$ In this context, it is unclear who the People is in her view, for on the one hand democracy is her starting point, on the other hand she justifies, even

124 Ibid at 523.

125 Ibid at 521.

126 Yael Tamir, Liberal Nationalism (Princeton: Princeton University Press, 1993) at 160.

127 Tamir, "A Jewish Democratic", supra note 119 at 519. 
endorses, what is essentially different categories of citizens implying different hierarchical classes within the People.

Of the writers who adopt liberal nationalism, Chaim Gans provides the most comprehensive analysis of defining Israel as a Jewish state. He notes that the current prevailing understanding of the meaning of the Jewish state is the state where Jews exercise Jewish hegemony and more favourable treatment for Jews. This hegemony is manifest in many areas: the constitutional definition, immigration policy, land policies, education, political participation, employment, the symbols of the state, and the dominant public culture to name a few. ${ }^{128}$ Gans rejects the arguments put forward by proponents of the nationalist approach that Jewish hegemony is justified based on national self-determination and analogous policies adopted by other states. He argues that self-determination does not necessarily mean statehood, but could also be exercised within the state - what he calls "sub-state" selfdetermination. The choice between the state and sub-state levels should be made according to the circumstances, taking into consideration the advantages and disadvantages of each option, and other values relevant to the determination such as equality. As for the content of the right, he says it has two main meanings: the right to self-rule and the right to secede. He does not see any of these meanings as supporting hegemony of one ethno-cultural group. ${ }^{129}$

Gans prefers a sub-statist exercise of the right of self-determination for Jews since he thinks that it can protect the interest of Jews in sustaining and preserving their culture over generations, and can provide most of the privileges Jews should enjoy. ${ }^{130}$ These include recognition and representation in the state's symbols and public life and preservation of

128 Gans, “A Just Zionism", supra note 33 at 55.

${ }^{129}$ Ibid at 57.

130 Ibid at 67-68. 
Jewish culture, in addition to "the implementation of measures that allow Jews to live in Israel in numbers sufficient for their culture to thrive." 131 These additional privileges do not mean exclusivity, hegemony or a Jewish majority. These are rights that all homeland groups should be entitled to, including the Palestinians in Israel. However, because of security concerns, the history of the Israeli-Arab conflict, the mistrust between the two communities in Israel, and the fact that Jews are a minority in the Middle East, Gans agrees that Jews are justified in adopting the view that the Palestinians, and the Arabs generally, "would ultimately not respect the Jewish people's interests in their survival as a distinct society." ${ }^{\prime 132}$ This, for Gans, is a valid argument for hegemonic Jewish self-determination where Jews enjoy a majority and can control military power. He limits this hegemony, however, to two specific areas Jewish majority and the military), and believes that they should be subject to human rights constraints, and limited in time until a mutual relationship of trust develops. ${ }^{133}$ Gans rejects Jewish hegemony in any area beyond these areas. As such, he is opposed to many of the existing laws and policies in Israel that give Jews preferential treatment and calls for autonomy in education for the Palestinian minority, and for their representation in the official symbols of the state. ${ }^{134}$

A Jewish majority, Gans asserts, is needed to allow members of the Jewish community to live within their cultural framework, but this does not justify the broad scope of the Law of Return. But still, Gans justifies an immigration policy that favours one ethno-cultural group. Such a policy, he argues, could be derived from the right to self-determination and from the

131 Ibid at 68.

132 Ibid at 79.

$133 \mathrm{Ibid}$ at $78-80$.

134 Ibid at $138-144$. 
interest of members of an ethno-cultural group to adhere to a specific culture, their feeling of self respect - especially for a historically persecuted group - and the fact that such preferential treatment serves the interests of the group as a whole, not just the ones immigrating. ${ }^{135}$ This nationality-based priority that Gans suggests here applies to Jews only and not to Palestinians, but he accepts that Palestinians should be able to sponsor their non-Israeli spouses through family reunification processes. He does not see this kind of privileging as violating any rights since the unprivileged group does not miss out on any important aspect of their lives. He further argues that "these privileges can be granted equally to all ethnocultural groups, so that for each and every ethnocultural group, there is a state ruling its homeland or part thereof within which it enjoys these privileges." ${ }^{136}$ It is therefore legitimate that Israel adopts an immigration policy that favors Jews, and the future Palestinian state would adopt a policy that favors Palestinians.

Gans does not specifically address the question of the People, but it seems based on his liberal framework and his support for sub-state self-determination that he supports a broad conception based on citizenship. However, he attributes significant normative value to ethnic nationalism under the pretext of protecting culture through ethnonational selfdetermination. This view of the world through the prism of ethnicity and the consequent allocation of some rights based on it is bound to weaken citizenship as the legal link between the individual and the state. ${ }^{137}$ Under this understanding, while one may be the citizen of one

\footnotetext{
135 Ibid at 121-122.

136 Ibid at 137.

137 There are other problems that could be highlight: Gans' conception of culture is rather antiquarian. The culture as he uses it seems to be uniform, static and unchanging and assumes that everyone is defined by this kind of culture. His application of these principles to Zionism highlights these problems. For example, he assumes the Russian Jews, Ethiopian Jews, and Chilean Jews etc, all share the same culture when in reality one
} 
country, his/her bome is a different country, a distinction that is open to manipulation and could mean that in order to realize full equality rights, he/she will have to emigrate to a different state. This strong emphasis implies a two-tiered citizenship in which some groups enjoy hegemony and their interests are given a higher priority. ${ }^{138}$ Even though this hegemony is limited, it is real, and its existence pushes in the direction of an exclusionary conceptualization of the People as those who belong to the hegemonic group and who see the state as their home.

Essentially, while Gans' analysis is more rooted in liberal thought, and is more sensitive to human rights and equality, he reaches conclusions close (but not identical) to those of Gavison and Rubenstein. The main difference is that the preference he gives to the national element is partial and is applied for a limited time and limited to certain policy areas. Still, the nation, or ethno-cultural group plays a large role that compares with the role of the People.

\subsection{Summary}

The opinions among liberals are diverse. Classic liberals insist that the state exists to serve its inhabitants and should treat them with equal respect and concern. Any definition which may imply preferential treatment for one group among the citizenry, even if it does not entail severe discrimination against another group, is not acceptable. For them the tension between

could say that each groups enjoys its own culture. Many scholars share this critique, including Shlomo Sand and Ronald Dworkin. See, Shlomo Sand, The Invention of the Jewish People (London: Verso, 2009); Dworkin, supra note 116. Dworkin said this in special reference to Gans's argument. For a more elaborate discussion of Dworkin's ideas, see above. Gans also ignores the important and constituent religious component in Judaism especially in Israel where the Orthodox rabbinical institution is the sole arbiter of deciding who is Jewish.

${ }^{138}$ Gans acknowledges the factual correctness of this assertion, but does not see it as a problem: infringement on neutrality and equality is not problematic because in practice neutrality and equality are impossible to realize on the state level: cultural equality should be aimed for a on the global level. Gans, "A Just Zionism", supra note 33 at $123-124$. 
the Jewish component and the (liberal) democratic component cannot be resolved, and Israel cannot be both liberal and Jewish at the same time. They are not hostile to the idea of the state promoting culture, but are mostly opposed to the differential implementation of such policies.

The views of the liberal nationalist writers reviewed vary to a certain extent, but how liberal is their nationalism? Kymlicka, one of the leading figures in this field identifies a set of constraining criteria that must be met for nationalism to qualify as liberal. Among those criteria he includes having a more open definition of the national community so that it is not restricted to race, ethnicity or religion; a thinner conception of nationality which allows individuals from different ethnocultural backgrounds to become full and equal members of the nation; recognition of the national minorities in terms of public space, symbols, and selfgovernment; the acceptance of the legitimacy of multi-national states in which more than one nation can coexist. ${ }^{139}$ As it stands today, none of these criteria exists in Israel, which, according to Kymlicka's framework, makes Israeli nationalism illiberal nationalism. Tamir's analysis did not delve into details, but her acceptance of the status quo shows that her approach does not seem to meet those constraints. Gans' approach seems to be the most compatible with these criteria except for the strong emphasis it places on ethno-nationalism making it the defining element of statehood. Under his model a significant number of people in the world are doomed to live under states that are not their "home", and they can only become fully equal, in terms of equal respect, if they move to their state of origin. To show the problematic nature of this position, it is best to use the words of Edwin Montagu - the only Jewish Minister in the

139 Will Kymlicka, Politics in the Vernacular: Nationalism, Multiculturalism, and Citizenship (Oxford \& New York: Oxford University Press, 2001) at 39-41. 
UK Government in 1917 which issued the Balfour Declaration - who argued against the Jewish state wondering how he would "negotiate with the peoples of India on behalf of His Majesty's Government if the world had just been told that His Majesty's Government regarded his national home as being in Turkish territory?"140

Although liberal nationalists restrict the acceptable constraints to limited areas such as immigration (and Gans constraints are further limited to the duration of the conflict, although he rejects the right of return of the Palestinian refugees), there is no guarantee that constraints will only be limited to that area. Once distinctions are made to favour the majority group in the name of culture, it is very likely that they will spill over to other areas. In this context, their final conclusions are very close to the conclusions and positions of the nationalists. Liberal nationalists, therefore, share with the nationalists and the pragmatists the ambivalent view of the People. They aspire to a People based on universal citizenship where all members are equal, but at the same time attribute significant weight to ethnic/national belonging which in itself could be a source of rights. Admittedly, the commitment to citizenship and equality is stronger, and the constraints that nationalism adds are not as far-reaching as the nationalists would accept. But at the moment of friction between the Jewish nature and the democratic character, the democratic gives way to the Jewish. In this sense, these moments of friction are also the moments when the ultimate political power in the state is most visible. These come when constitutional changes are at issue for example, as will be discussed in chapter VI, or in situations related to immigration policy, as will be discussed in chapter IV. In these situations,

140 David Lloyd George, The Truth About the Peace Treaties (London: Victor Gollancz, 1938) vol 2 at 1134. 
given the commitment to liberal citizenship, but also the prominence of the national (Jewish) element, it is not clear who would be included in the People.

\section{Critical Approaches}

While some of the writers reviewed so far are critical of Israel's constitutional definition, such as Joseph Raz and Ronald Dworkin, and others justify the definition but criticize some policies such as Chaim Gans, other writers have taken more critical approaches to the question of the Jewish and democratic elements of the definition incorporating dimensions ignored by the liberals or liberal nationalists, such as the colonial past and reality. Rather than provide a justificatory account, their analysis is more rooted in the sociological realities of life, probing and examining the meaning and the impact of the definition as lived by the people in the state, especially the Palestinian minority. ${ }^{141}$ The emphasis on historical narratives and the sociological reality of the situation in Israel, and taking it as a starting point, situates the writers reviewed in this category in a better place to capture the tensions in the definition and offer the most persuasive insights. This dissertation will build on the insights

141 In addition to the writers whose work is discussed here, one can add a number of other authors who are also critical of the definition and whose work could easily fall under this category, such as Ariella Azoulay, Gad Barzilai, Aeyal Gross, As'ad Ghanem, Yousef Jabareen, Amal Jamal, Michael Karayanni, Baruch Kimmerling, Adi Ophir and Oren Yiftachel. See Gad Barzilai, Communities and Law: Politics and Cultures of Legal Identities (Ann Arbor: University of Michigan Press, 2003); Gad Barzilai, "Fantasises of Liberalism and Liberal Jurisprudence: State Law, Politics, and the Israeli Arab-Palestinians Community" (2000) 34 Israel Law Review 425; As'ad Ghanem, Ethnic Politics in Israel: The Margins and the Ashkenazi Center (London: Routledge, 2010); Gross, "Democracy", supra note 69; Yousef T. Jabareen, "Constitution Building and Equality in Deeply-Divided Societies: the Case of the Palestinian-Arab Minority in Israel" (2008) 26:2 Wisconsin International Law Journal 345; Amal Jamal, "Contradictions of State-Minority Relations in Israel: The Search for Clarifications" (2009) 16:3 Constellations 493; Michael Karayanni, "Multiculture Me No More! On Multicultural Qualifications and the Palestinian-Arab Minority of Israel" (2007) 215 Diogenes 39; Baruch Kimmerling, "Religion, Nationalism and Democracy in Israel" (1999) 6:3 Constellations 341; Baruch Kimmerling, Clash of Identities: Explorations in Israel and Palestinian Societies (New York: Columbia University Press, 2008); Ariella Azoulay \& Adi Ophir, This Regime Wbich is Not One: Occupation and Democracy Between the Sea and the River (1967- ) (in Hebrew) (Tel-Aviv: Resling Publishing, 2008); Oren Yiftachel, Ethnocracy: Land and Identity Politics in Israel/Palestine (Philadelphia, PA: University of Pennsylvania Press, 2006). 
they provide and further develop some arguments they make, while at the same time constantly engaging with writers who belong to the other approaches reviewed.

Azmi Bishara is probably the most well-known critic of the definition. To some extent, many of the writers reviewed under other categories such as Gavison, Barak, Rubenstein and Yakobson situate their writing as being in part in opposition to the views represented by Bishara and other writers who advocate for "a state of all its citizens". Bishara's starting point is that Israel is a settler colonial state that defines itself as Jewish and democratic. This leads to two structural contradictions, the first between democracy and the colonial situation, and the second between democracy, religion, nation and citizenship. The contradiction between democracy and the colonial nature is evident in the present, not just in the past. It is part of the current reality that regenerates itself as part of the state structure. One of the consequences of this contradiction is the pervasiveness of settler culture which entails values emphasizing security, military service, the collective interests of the group, and a constant feeling of threat. ${ }^{142}$

The second contradiction that Bishara identifies is in the relationship between democracy, religion and citizenship, which is not limited to the classic debate on the separation between church and state. Because it has far-reaching implications for the question of citizenship in the case of Israel, Bishara argues that the problem of the relationship between religion and the state has constitutional implications that relate to the roots of democracy. $\mathrm{He}$ highlights the Zionist context in which Israeli democracy has developed. The state is a Jewish state as a result of the consensus in the Zionist movement; the state was created to serve a

142 Azmi Bishara, From the Jewish State to Sharon: A study in the Contradictions of the Israeli Democracy (in Arabic) (Ramallah: MUWATIN- The Palestinian Institute for the Study of Democracy, 2005) at 16 [Bishara, "From the Jewish State']. 
function - to absorb Zionist immigration. As such, "Zionism, and not citizenship, is the container of the Jewish democracy, and at the same time it is a barrier for its development. For in moments of crisis, it does not go beyond being a democracy within the tribe."143 This is evident in the Law of Return and the religious definition it adopts. Israel, therefore, cannot separate citizenship from national affiliation, because citizenship is mainly acquired through membership in the nation, and the nation is defined by religion. Zionism, Bishara argues, despite the secularism of its founders, was not able to articulate a secular definition for Jewish nationality except through religion. Separation between religion and state, therefore, is impossible. ${ }^{144}$ The failure of the state and its institutions to separate the national identity from the religious one means that the process of sovereignty in Israel has not been completed yet. ${ }^{145}$

Bishara finds more evidence that this is the actual meaning of the Jewishness of the state in the classic understanding that prevails in Israeli political culture that distinguishes between "rights on the state" and "rights in the state". The former, which is reserved for Jews, which includes the right to "return", is one that precedes and transcends the state, while the latter, which represent the rights of the Palestinians, are rights given by the state to the inhabitants. The actual meaning is that the national rights over the state are only Jewish rights. Sovereignty is only limited to them, and by virtue of this sovereignty they give rights to those who lack sovereignty. This distinction, Bishara argues, is fictional and theoretically impossible, and has historically been used to rationalize ethnic cleansing and discrimination. ${ }^{146}$ It also means that equality is impossible. Since this is the actual meaning of the definition, Bishara

\footnotetext{
143 Ibid at 25 [translated by author].

144 Ibid at 31-35.

145 Bishara, "The Sovereignty", supra note 69.

${ }^{146}$ Bishara, "From the Jewish State", supra note 142 at 35-37.
} 
rejects it and advocates for a democratic regime where the state is the state of all its citizens. This could be promoted through a multicultural or bi-national democracy where Palestinians constitute one nation and the other nation is Israeli Jews. ${ }^{147}$ This option is preferable because it is more reflective of the reality on the ground and is the only possible option that would secure equality of both Palestinians and Jews. ${ }^{148}$

In the same vein, Nadim Rouhana adopts the settler-colonial analysis of the situation and argues that the ethnic definition of the state is in direct contradiction with the multi-ethnic reality. ${ }^{149}$ As such, Israel cannot provide full equality or inclusion. ${ }^{150}$ This contradiction, he asserts, was concealed by security considerations, such that many discriminatory policies which are the result of the ethnic definition were erroneously attributed to security concerns. With the peace process in the 1990 s and the change in security needs, the contradiction between the ethnic preference and democracy has become clearer. ${ }^{151}$ Rouhana sees the emphasis on the definition as part of what he and Nimer Sultany call a "New Zionist Hegemony" which supports new discriminatory policies. ${ }^{152}$ He sees this uncritical embrace of the Jewish and democratic formula, despite the bi-national reality, to be a form of national

147 Bishara, "The Sovereignty", supra note 69 at 382.

${ }^{148}$ Azmi Bishara, On Being Arab in the Present Day (in Arabic) (Beirut: Center for Arab Unity Studies, 2009) at 178180.

${ }^{149}$ Nadim N. Rouhana, "Zionism's Encounter with the Palestinians: The Dynamics of Force, Fear and Extremism" in Robert I. Roteberg, ed, Narratives of Israel and Palestine: History's Double Helix (Bloomington, IN: Indiana University Press, 2006) 115.

150 Nadim N. Rouhana, "Israel and Its Arab Citizens: Predicaments in the Relationship between Ethnic States and Ethnonational Minoritites" (1998) 19:2 Third World Quarterly 277 [Rouhana, "Israel and its Arab"]; Nadim Rouhana, Palestinian Citizens in an Ethnic State: Identities in Conflict (New Haven \& London: Yale University Press, 1997) at 48-56.

151 Rouhana, "Israel and its Arab", ibid at 286.

152 Nadim N. Rouhana \& Nimer Sultany, "Redrawing the Boundaries of Citizenship: Israel's New Hegemony" (2003) 33:1 Journal of Palestine Studies 5. 
self-deception. ${ }^{153}$ Based on these (and other) observations about the relationship between the state and Palestinian citizens, and their unequal status, Rouhana questions whether Israel could truly be described as a democracy. He argues that "Israel has some democratic features, although it captures the aspect of democracy without equal citizenship."154 Rouhana also highlights what he calls the "politics of historical denial" - the Israeli official narrative of the Palestinian citizens being "Israeli Arabs", lacking historical roots or narratives, and living in the "Jewish homeland" in a manner similar to an immigrant community. The politics of historical denial is one of the reasons for the absence of basic equal democratic citizenship and it also impedes the development of a more robust multicultural citizenship. ${ }^{155}$ The politics of historical denial, Rouhana adds, could also explain why Israel is usually described as a democracy in academic literature. ${ }^{156}$ Academic studies usually adopt the prevailing official historical narrative, which leads to placing more emphasis on some of the liberal rights that the Palestinian citizens have while totally ignoring the historic injustice caused by the creation of Israel and the implications of this injustice. This tendency, Rouhana posits, is also influenced by the relationship between power and knowledge in academia and the complex relationship between the West and Jews. ${ }^{157}$

Focusing on the jurisprudence of the Supreme Court of Israel, Hassan Jabareen explains how the interpretation of Israel's definition is contrary to the bi-national reality, and

\footnotetext{
153 Nadim N. Rouhana, "Jewish and Democratic'? The Price of a National Self-Deception" (2006) 33:2 Journal of Palestine Studies 64.

${ }^{154}$ Nadim N. Rouhana, "Reconciling History and Equal Citizenship in Israel: Democracy and the Politics of Historical Denial" in Will Kymlicka \& Bashir Bashir, eds, The Politics of Reconciliation in Multicultural Societies (Oxford: Oxford University Press, 2008) 70 at 85.

155 Ibid at 86.

156 Ibid at 85 .

${ }^{157}$ Ibid at 86.
} 
is deficient concerning equality rights. ${ }^{158} \mathrm{He}$ highlights the limits of equality under this definition by analyzing the Supreme Court decision in Ka'adan which is often celebrated as a breakthrough in the promotion of equality by the Court. ${ }^{159} \mathrm{He}$ argues that the Court's approach to equality and to Israel's values as a Jewish and democratic state represent a new form of "Israeliness" that is only future-oriented, which could also include Palestinians, but this inclusion would be "made conditional on their renouncing components of Palestinian identity, instead assuming the 'Israeli Arab' identity, which is characterized by Zionist components, including the acceptance of the ideological values of Zionism."160 This model, which is underpinned by legislation and case law, at most deals with Palestinian citizens in Israel as groups that have the status of ethnic immigrant groups, with rights limited to the civil-political sphere. The model may tolerate a limited recognition of some cultural aspects, as long as this recognition does not impact the ideological structure of the state. This model fails to recognize the Palestinians as an indigenous group that is entitled to self-determination within the state. ${ }^{161}$

Jabareen highlights that while the Court did rule that the Jewish definition of the state does not justify discrimination, the Court's reasoning was flawed, and viewed the petitioners

158 Hassan Jabareen, "The Future of Arab Citizenship in Israel: Jewish-Zionist Time in a Place with no Palestinian Memory" in Daniel Levy \& Yifaat Weiss, eds, Challenging Ethnic Citizenship, , New York: Berghahen Books, 2002) 196 [Jabareen, "The Future"]. Hassan Jabareen is the founding director of Adalah, a human rights organization that promotes the individual and collective rights of the Palestinian minority in Israel.

${ }^{159} \mathrm{HCJ} 6698 / 96$ 'Adel Ka'dan v. Land Administration of Israel (2000), IsrSC 54 (1) 258. The case originated in a petition to the Supreme Court against the Israel Land Administration and the Jewish Agency for refusing to sell land in the town of Katzir to an Arab citizen. This refusal was justified because the land was allocated to the Jewish Agency, which, beholden to Jews only, is justified in discriminating against Arab. Both respondents also argued that this is permissible given Israel's values as a Jewish and democratic state. The Court, using an antidiscrimination approach, decided that the values of the Jewish and democratic state do not justify discrimination against non-Jews.

${ }^{160}$ Jabareen, "The Future", supra note 158 at 197.

161 Ibid. 
as individuals who did not ignore the Jewish identity of the state, neither did they ignore the history of settlement; they were not seeking recognition or redress for past injustices. They are portrayed as non-Jewish citizens that agree and accept all of the Zionist principles and assumptions, even those that conflict with their interests. The only group that could be seen as a nation is the Jews. ${ }^{162}$ There was no mention of any history of discrimination against the Palestinians at all. In fact, they are not there at all. Instead, there are different and smaller minority groups that are recognized as Muslims, Christians, Druze, or Bedouins. ${ }^{163}$ The reason for this fragmentation, Jabareen asserts, is that recognizing Palestinian Arabs as members of one nation, as opposed to different ethnic groups, will threaten the conception of Israel as a Jewish nation-state.

This approach, Jabareen contends, negates the Palestinian identity. It is not only a matter of lack of collective rights or recognition as a national minority; it also affects the individual level. Because the Palestinian individual cannot identify with his/her nationality, and he/she is even required to show contempt for his/her nationality, the personal autonomy of the Palestinian individual is limited and restricted. On the other hand, because Zionism does not attribute a lot of importance to the ideological side beyond identification as Jewish, the Jewish individual is free to be Zionist, anti-Zionist or whatever other affiliation he/she

\footnotetext{
162 Ibid at 204.

163 In one of the documents of the World Zionist Organization from 1920, it was decided that the way to deal with the Palestinian Arabs was to fragment them into sects and classes. The plan included strengthening the relations with Bedouin tribes and Zionist leaders so that the former would sever their relations with the national activists who were usually part of the urban elite. It also included encouraging conflicts between Christians and Muslims. See Hillel Cohen, Army of Shadows: Palestinian Collaboration with Zionism, 1917-1948 (Berkley: University of California Press, 2008) at 17-18. Throughout the book the author explains and gives examples of the implementation of this plan.
} 
wants. ${ }^{164}$ This gives the Jewish individual a broader personal autonomy without risking or limiting the civil-political rights he/she enjoys. As a result, Jabareen argues, Israel fails to establish civil and political rights on the individual level since equality on the individual level is also related to equality on the collective level. ${ }^{165}$

Like Rouhana, Jabareen identifies the crux of the problem by stating that Israel is actually, as a matter of fact, a bi-national state. The fact that the state defines itself otherwise does not make it a nation-state since the test is the territorial principle, the homeland. The very adoption of the nation-state model to justify the situation is an attempt to shift the debate from the legitimacy of the current situation to a debate about the nation-state model, disregarding the bi-national reality. ${ }^{160}$ Attempts to reconcile the Jewish and democratic components are deficient because they operate within the accepted dichotomy between the Jewish state and the democratic character. The assumptions are accepted without being problematized. Jabareen seeks to subvert this discussion by providing an analysis based on the relevance of the fact that the Palestinian citizens are a homeland group. Approaching the issue this way, he posits that the real question to be asked is "is the definition of the state as a 'Jewish' state a matter of 'cultural violence'?" which "embodies a negation of the national existence of the homeland group, the collective memory, history, demands for acknowledgment of the historical injustice it has suffered, language, and so on." "167 Jabareen finds further evidence of this negation in a Supreme Court decision from 1972 when the

164 Many Ultra-Orthodox Yeshiva students belong to religious streams that are anti-Zionist, but still get state funding and support. Their rights are not seen as contingent on the adoption a Zionist outlook.

165 Jabareen, "The Future", supra note 158 at 212-213.

160 Ibid at 209.

167 Ibid at 214. 
Court refused to recognize an Israeli nation or people. ${ }^{168}$ As Jabareen sees it, this does not mean "a negation of Israeliness, but means the existence of a Jewish nationality which is also the Israeli nationality, on the one hand, and the rejection of the introduction of others to the area of this identity, on the other."169

Jabareen suggests that to better understand the constitutional system in Israel, one has to take into consideration the treatment of Palestinians on both sides of the 1948 Green Line. He argues that the "Jewish and democratic" definition adopts "situational discrimination" (discrimination in specific policy or geographical areas) which allows for discrimination against the Palestinian citizens. The "situational discrimination" finds its clearest manifestation in three situations: (1) "separate but unequal", like in the case of the Law of Return; (2) "the proportionality test" in situations when simple discrimination is legitimized using this test; and (3) situations that Jabareen calls "plenary sovereignty" which are characterized by the suspension of the rule of law. Taken as a whole, Jabareen argues that the Israeli constitutional system distinguishes mainly between two groups, Jews and Palestinians, and creates hierarchy among the Palestinians (those who are Israeli citizens and OPT Palestinians). ${ }^{170} \mathrm{He}$ also argues that "discrimination is a situational constitutional principle"171 and concludes that "the Israeli constitutional system itself points out the party that holds sovereignty through the implementation of Law of Return". ${ }^{172}$ For Jabareen, this is what defines "we the people". The

${ }_{168}$ CA 630/70 Tamarin v. The State of Israel (1972), IsrSC 26(1). A similar approach was taken by the Jerusalem District Court in 2008, see HP (Jerusalem) 6092/07 Oman v. Ministry of Interior (2008) [pending appeal].

169 Hassan Jabareen, "Towards Critical Approaches to the Palestinian Minority: Citizenship, Nationhood and Feminism in Israeli Law" (in Hebrew) (2000) 9 Plileem 82.

${ }^{170}$ Hassan Jabareen, "The Constitutional Conception of the 'Jewish and Democratic' State" in Honaida Ghanim \& Antwane Shalhat, eds, The Meaning of a Jewish State (in Arabic) (Ramallah: MADAR The Palestinian Forum for Israeli Studies, 2011) 33.

171 Ibid at 53 [translated by author].

${ }^{172} \mathrm{Ibid}$ at 57 [translated by author]. 
People, therefore, are the Jewish people. As such, the Palestinian citizens are excluded from the People.

Raef Zreik examines the meaning of the "Jewish and democratic" definition from the point of view of constitutional theory. He focuses on two theoretical approaches to constituent powers. In the first one, constituent power expires with the creation of the constitution (he calls this the 'institutional approach'). Such states exhibit, from time to time, some features of exceptions which disclose a violent or lawless origin. These features are always downplayed and pushed to the margins to highlight other features such as legality, but still, the former features loom below the smooth surface. The second approach, that of Carl Schmitt, sees revolution as permanent with the will of the People as the ultimate arbiter of power - the one that decides the exception. This understanding is also limited to Schmitt's understanding of the People - an ethnically homogenous group that is capable of deciding friend and enemy. Zreik sees Israel as falling within the latter category. The Zionist "revolution" that created the state did not end with the creation of the state. It is still present with the emphasis on ethnic nationalism. Thus, the contradiction in the definition between democracy and Jewishness is seen as part of a bigger conflict between a revolutionary approach which sees (Jewish) revolution as permanent, and an institutional approach, which wants to consolidate the state as the only locus of power-making decisions. ${ }^{173}$ Zreik does not explicitly deal with the question of "who is the People?", but his treatment of the topic points in the direction of seeing the Jewish people only as the People in Israel, which is represented by the permanent Zionist revolution that refused to be consolidated by the state. This

${ }^{173}$ Raef Zreik, "The Persistence of the Exception: Some Remarks on the Story of Israeli Constitutionalism" in Ronit Lentin, ed, Thinking Palestine (London: Zed Books, 2008) 131, at 138-145. 
formulation is in conflict with a competing formulation represented by the institutional approach that seeks to "to declare that the revolution is over and the state is the only site for making decisions over the future of its citizens." ${ }^{174}$

Zreik's attempt to situate the religious/ethnic nature as part of the "permanent revolution" is helpful in understanding its origins and current role. In this regard, however, the dichotomy is not as clear as Zreik presents it. Even according to the dichotomy that he presents of ethno-religious revolution/constitutionalism (or the ethnos/demos), what is happening in Israel since the enactment of the 1992 basic laws is that attempts to push for an institutional approach resulted in the (ethnos/demos) tension being subsumed by constitutionalism, or the institutional approach. Rather than the consolidation of the institutional approach being a tempering force against ethno-religiosity, it became part of it, making the Zionist "revolution" not only visible but a central feature of constitutionalism.

In summary, most of the writers in this category find the Jewish and democratic elements in the definition to be an irreconcilable contradiction. They point out the dominance of ethnic/religious element over democracy, and emphasize that this constitutional (which is by definition normative) definition is in direct conflict with the bi-national reality. The lack of recognition of the Palestinians as a national homeland group entitled to collective rights makes the definition as a Jewish state part of the discrimination policy. It also means discrimination on the collective and individual level. As part of the Zionist ideology, the definition also means the continuation of policies that were historically adopted to achieve Jewish hegemony, and blocks any chance of providing redress for past injustice in areas such as land policy

${ }^{174} \mathrm{Ibid}$ at 144 . 
because addressing these issues will require questioning Zionism and its policies. These policies are also seen as part of settler colonialism in that they try to galvanize an immigrant society around an idea of a nation and at the same time dispossess the native group. For most of the writers here, the reality of the situation today is that sovereignty and political power is limited to Jewish Israelis who are the People. This critical description of the nature of constitutional structure in Israel stands in contrast with a prospective view of the People which many of these writers support, one that either includes all of the citizens of the state equally with no preferential status, or one that views the People as comprised of constituent groups or nations which are equal. In this most are in agreement with Liberals such as Raz and Dworkin, but they find the interpretations provided by the liberal nationalists and the nationalists to be flawed and meant to justify and perpetuate the status quo.

\section{Conclusions}

From the different approaches reviewed here - ignoring the ultra-nationalist approach - it becomes clear that one of the ways to explain and justify the definition of the state is the distinction between the ethnonatinal/religious group, the ethnos, and the People of the state defined as the collective of citizens, the demos or the People. Supporters of the nationalist approach, the pragmatists and the liberal nationalists see that associating the state with the etbnos (Jews) is justified as long as there is a Jewish majority, provided that equality and civil and political rights of the other citizens are protected. What seems to be discrimination, they argue, is either not discrimination at all, or justified discrimination. A state, (or nation-state which seems to be the preferred characterization) is justified in adopting policies that give preferential treatment to the majority nation and associate the state with that nation as long as 
equality among the individual members of the demos is observed. Gans stands out in stating that this approach could only be an arrangement that is limited in time and that the benefits it bestows on the majority group should be limited in scope. Gans' approach however is very remote from the current reality in Israel. The policies of the three authorities in Israel (legislative, executive and judicial) reflect an understanding of the Jewish and democratic state which seems to fit the nationalist approach, and to a lesser extent, the approaches of Aharon Barak and Sami Smooha. Opposing the nationalist and pragmatic approaches are the critics. They see that the primacy of one ethnos and its association with the state makes the distinction between etbnos and demos as a device that entrenches existing discrimination and diminishes democracy.

But what does this distinction between the ethnos and the demos mean exactly in a state that is defined as belonging to one etbnos? What does it mean in relation to Israel's definition? Is it just merely a matter of limited symbolic benefits that the majority group enjoys without infringing on the rights of the Palestinian minority? What does it say about the allocation of political power? What does it mean in terms of sovereignty, constituent power and the constitutional order? The following chapters will try to answer some of those questions by examining in greater depth the question of the People in Israel as one of the elements of democracy. The examination will focus on the constituted form (the existing constitutional order, state institutions and the different laws and policies adopted). By examining the foundational texts and their status and role, and the constitutional and legal provisions that affect citizenship, political representation and constitutional change, a better picture of who the People in Israel is can be painted. 


\title{
Chapter III
}

\section{Locating the People in Israel: The Social Contract,}

\author{
the Basic Norm, and the Beginnings of the State
}

\section{Introduction}

Prima facie, an inquiry into who is the sovereign in Israel is simple. The Supreme Court has stated on a number of occasions that in Israel the People is the sovereign. This was held in a number of Supreme Court decisions, including Bank Mizrabi HaMe'ouba v. Migdal Kfar Shitofui, which affirmed the constitutional status of basic laws and their superiority over regular legislation. ${ }^{1}$ In this decision, former Chief Justice Barak stated that

[i]ndeed, sovereignty in a democratic state belongs to the People. Sovereignty does not belong to the Knesset, nor does it belong to the Government, nor does it belong to the courts. The sovereignty belongs to the People. On it, the whole social and legal construct is based. The beginning of the emergence of the constitution and the basic laws is in the People, and they are based on the People, and the People is authorized to change them. The Knesset's constituent authority emerged from the People, was recognized by the People, and was not used behind its back. ${ }^{2}$

Barak relates this idea to democracy when he adds that the fundamental principles of democracy are based "on the recognition of the sovereignty of the People that is expressed in

\footnotetext{
${ }^{1}$ CA 6821/93 Bank Mizrabi HaMe'ouba v. Migdal Kfar Sbitofui (1995), IsrSC 49 (2) 221 (in Hebrew) [Bank Mizrabi]. It should be mentioned here that former Chief Justice Meyer Shamgar had a different position. His approach favored a model that is similar to the British Parliamentary sovereignty model. Still, Shamgar referred back to the people, and justified his position by saying that the Knesset is sovereign (in the Austinian understanding of the term- as the highest authority that can make law) because it gets its authority from the people, which is the sovereign. See para. 23 of the C.J. Shamgar opinion.

2 Ibid at 399 [translated by author]. The position that the People is the sovereign in Israel has been repeated several times in the case law. See EC 11280/02 Central Elections Committee for the Sixteenth Knesset v Tibi (2003), IsrSC 57(4) 1 (in Hebrew) [Tibi]; HCJ 1661/05 Gaza Sbore Regional Council v The Knesset (2005), IsrSC 59 (2) 481 (in Hebrew) [Gaza Shore Regional Council]; HCJ 6427/02 The Movement for the Quality of Governance in Israel $v$. The Knesset (2006) (in Hebrew) [Movement for the Quality of Governance].
} 
free and equal elections..."3 One could argue then that the People is all of those who have the right to vote since "the sovereign is the People" and " $[\mathrm{t}]$ he People elects the Knesset." On the other hand, the Supreme Court also defines Israel as the state of the Jewish people even before the enactment of the basic law provisions designating the state as a Jewish and democratic state. ${ }^{5}$ Justice Elyakim Rubenstein ${ }^{6}$ even went as far as characterizing sovereignty in Israel as Jewish sovereignty when he asserted that "the Jewish people has won sovereignty after two thousand years of exile, and the Jewish sovereignty is a deposit that is the most precious in the Jewish history. It is an obligation for our generation, and all generations, to protect it and its security." In a different paragraph in the same opinion, he describes the state as "Jewish and democratic sovereignty". ${ }^{8}$ The question of who is sovereign and whether it is Jewish sovereignty, or the People's sovereignty, and who is included in the People is not so simple to answer.

This chapter, and the following chapters, will focus on this question: who holds sovereign power, or who is the People in Israel? The chapter will begin the inquiry into this question focusing on two aspects. In the first part of this chapter, I will examine the way Israeli courts have applied some of the theories of peoplehood discussed in chapter I. Here I will focus mainly on two theories discussed in the case law and literature; the social contract theory and the Kelsenian basic norm. The courts have resorted to these two theories in order to explain the theoretical foundations of the constitutional regime, especially in cases that dealt

\footnotetext{
${ }^{3}$ Tibi, ibid, at para. 14 [translated by author]. See also HCJ 761/86 Mi'ari v. Speaker of the Knesset (1987), IsrSC 42(4) 868 (in Hebrew).

${ }^{4}$ Gaza Shore Regional Counicl, supra note 2 at para. 91 [translated by author].

${ }^{5}$ See e.g. EA 1/65 Yerdor v. Central Election Committee for the Sixth Knesset (1965), IsrSC 19 (3) 365 (in Hebrew) [Yerdor]; Tibi, supra note 2.

${ }^{6}$ Elyakim Rubenstein, not to be confused with Amnon Rubenstein the leading constitutional law scholar.

${ }^{7}$ HCJ 466/07 Galon v. The Attorney General (2012), at para. 3 of Justice Rubenstein's opinion (Hebrew).

${ }^{8}$ Ibid at para. 46.
} 
with constitutional questions that touch on the legitimacy of the constitutional regime, or in situations when the courts wanted to furnish further theoretical grounding for the outcome of their decisions beyond constitutional interpretation. The second part of this chapter will be the beginning of a consideration of the question of the People through the prism of the constitutional regime; a topic canvassed in the scholarly literature in chapter II. I will focus on the creation of the State of Israel and the Declaration of Independence. This line of inquiry will continue over the next three chapters. Topics discussed in chapter I such as reflexive constitutionalism, and the meaning of the People in plurinational states and settler colonial states, will be weaved throughout these parts. The discussion in the following chapters will center on how constitutional principles, legal provisions and governmental policies shape and define the People. The discussion will include an analysis of Israel's immigration and citizenship laws and policies and their impact on engineering the People. The different ways the People exercises political power in Israel through the constitutional regime will be discussed afterwards. The examination of all of these aspects discussed in this chapter and the following chapters will allow for identifying the locus of sovereignty, or the locus of ultimate political power in Israel.

\section{The People in Israel Between Theory and Practice: Social Contract, Basic Norm and Nation}

Two ideas about the origins of the Israeli legal system are often discussed in Israeli jurisprudence and literature: the social contract theory as the source of authority, and the basic norm. I will examine the treatment of both concepts in Israeli jurisprudence in order to examine the way they have been applied with relation to the idea of the People, and the 
different mechanisms of inclusion and exclusions this application entailed. In the same vein of examining the ways theories of peoplehood were applied, I will examine the judicial treatment of the question of the existence of an Israeli nation. The question of whether a civic Israeli nation that includes all citizens exists has been raised at least twice, but was rejected by courts and even deemed to be contrary to the idea of Jewish self-determination.

\subsection{The Social Contract Theory in Israel}

Israeli constitutional law recognizes a hypothetical social contract that is the basis of the state. Following leading social contract theories, as discussed in chapter I, the idea is that individuals came together to form a contract amongst themselves to create the constitutional order or the state. This theory was mentioned and discussed in a number of decisions by the Supreme Court. ${ }^{9}$ Its most detailed and consequential discussion was in Academic Centre for Law and Business v. Minister of Finance, which challenged the constitutionality of legislation that allowed for the privatization of prisons. ${ }^{10}$ In this decision, based on quotes from leading social contract theorists such as Hobbes and Locke, then Chief Justice Dorit Beinisch (with the majority of Justices concurring) adopted an approach that assumes a social contract as the basis of the modern democratic state. Justice Arbel even called the social contract "the genetic code of the state." ${ }^{11}$ One of the basics of this social contract is that only the state is authorized by the polity to use force in order to restrict the personal liberty of individuals. This power stems from sovereignty, and its transfer to a private body is akin to a state abandoning its duties according to the contract. Although the social contract theory was accepted by most

9 The social contract was discussed as obiter in a number of cases, see e.g. Bank Mizrabi, supra note 1; HCJ 164/97 Contram Ltd. V. Ministry of Finance- Customs and VAT Branch (1998), IsrSC 42(1) 289 (Hebrew); Gaza Shore Regional Council, supra note 2; The Movement for the Quality of Governance, supra note 2.

10 HCJ 2605/05 Academic Centre for Law and Business v. Minister of Finance (2009), (Hebrew) [ACLB].

11 Ibid at para. 2 (opinion of Justice Arbel) [translated by author]. 
judges, some Justices took the position that it should be seen as a tool of last resort to be used cautiously and in a reserved manner. ${ }^{12}$

The discussion in $A C L B$ focused on individual liberty and did not provide any indications as to who is included in the contract. But the discussion in another Supreme Court decision could be helpful in providing more indications about the scope of inclusion/exclusion in the social contract. Three years earlier, in The Movement for the Quality of Governance in Israel v. The Knesset (2006), the Supreme Court issued its decision upholding the constitutionality of a law that defers mandatory military service for ultra-orthodox yeshiva students. ${ }^{13}$ In practice, deferral meant exemption from service. The then Deputy Chief Justice Michel Chechin used the social contract theory in his minority opinion which held that the law was unconstitutional. In his dissenting opinion, Chechin asserted that in every state

and certainly in a nation state, there is a "social contract" that constitutes the basis for the common life of the members of the society. This contract -and it is the genetic code of the state- includes the main values that the state is built on; and draws the basic lines for the construction of the state; and in it the framework rules according to which the state will be administered are determined. The contract is the principal and the essence of the life of the state, and constitutes the common denominator of the lives of its citizens and residents. ${ }^{14}$

Chechin added that some of the contents of this contract found explicit expression, in the constitution or in legislation, but others, while influential, did not receive such expression. They are, nonetheless, part of the daily life in the state and are seen as basic values of the legal system. Written laws, Chechin opined, "in essence, are nothing but a declaration of these values and principles that the state is built on."15 These basic values, which are part of the social contract, play a role in the legal system, and could, during extraordinary situations,

12 Ibid (opinion of Justice Na'or).

${ }^{13}$ Yeshiva is a school for religious studies.

14 Movement for the Quality of Governance, supra note 2 at para. 9 (opinion of Deputy Chief Justice Chechin) [translated by author].

${ }^{15}$ Ibid [translated by author]. 
directly dictate certain outcomes. ${ }^{16}$ In his analysis, the exemption violates three basic values that are part of this contract; these are the Jewish element, the democratic element, and equality. ${ }^{17}$ When he discussed the Jewish element, he highlighted the security threats the state faces. He posited that without a strong army, there cannot be a Jewish state, and concluded that an exemption from military service for part of the population is a violation of the "Jewish" values which are part of the contract. It is also a violation of equality. The Jewish definition is therefore a basic value of the social contract, and by extension, so is service in the army.

Chechin's opinion was a minority opinion in this case, and the then Chief Justice Barak criticized both the outcome and the methodology. ${ }^{18}$ But Barak said that he agreed that there is room for the view that a statute or a Basic Law that negates the character of Israel as a Jewish and democratic state is not constitutional. The People, the sovereign, did not authorize our Knesset to do so. The Knesset was authorized to act within the framework of the basic principles of the regime. It was not authorized to annul them. This case before us does not fall within that narrow frame. ${ }^{19}$

In an interview published in 2009, Barak said that he agreed with Chechin's approach that there are principles that are above the constitution, such as the Jewish and democratic character of the state, which cannot be changed even by the Knesset. ${ }^{20}$

The social contract theory, as adopted and implemented by the Court, raises the Jewish and democratic definition to a level which is supra-constitutional. Given the prevailing meaning of the definition which highlights the national rights of Jews and relegates the rights

\footnotetext{
${ }^{16}$ Ibid at paras.10-11.

17 Ibid at para. 12.

${ }^{18}$ Barak's main critique was that the examination of the constitutionality of legislation should proceed according to the Basic Laws by examining the protected rights and the "limitation clause" which provides the proportionality tests, which include the basic values of the system.

${ }_{19}$ Movement for the Quality of Governance, supra note 2 at para. 74 (opinion of Chief Justice Barak) [translated by author].

${ }^{20}$ Ariel L. Bendor and Zeev Segal, The Hat Maker: Discussions with Justice Abaron Barak (in Hebrew) (Or Yehuda: Kinneret Zmora-Bitan Dvir Publishing House Ltd., 2009) at 144.
} 
of the Palestinian citizens to individual rights only, it is unclear whether the Palestinian citizens agreed, or would have agreed hypothetically, to such a contract, especially since it frequently leads to infringements of individual rights. ${ }^{21}$ Even the Kantian approach to consent, which is based on reason, cannot be relied on. It is doubtful that the Palestinian citizens would have reasonably consented to an arrangement that does not provide full equal rights. The inclusion of the Jewish nature of the state, and mandatory military service (which mainly applies to Jews), in the social contract raises questions about the inclusion of the Palestinian citizens in the contract, especially since they are exempt, and resist any attempts to impose compulsory military service on them as a group. Most of them, furthermore, do not share the sense of constant threat or the need for a strong military. Since the social contract is seen as the basis of the state that justifies its political authority and underlies sovereignty, doubts about inclusion in the social contract also means doubts about being part of the People that exercises sovereignty and constituent power.

The social contract in this sense could be best explained as an intra-Jewish social contract that includes the Jewish definition and military service and partaking in the feeling of being under permanent threat which justifies the need for this service. Support for this assessment could be found in a number of initiatives in the early 2000 s that aimed at discussing and negotiating some elements of shared life in Israel. Two initiatives focused on issues related to problems or tensions in Israeli society. One initiative, called the Gavison-Medan Covenant after the two individuals leading the discussions, Ruth Gavison and Rabbi Yaccov Medan, aimed at achieving "a new framework agreement between observant and non-

\footnotetext{
21 This point will be examined in detail in chapters IV, V and VI.
} 
observant Jews in Israel". ${ }^{22}$ The Covenant, adopted in 2003, was built on the idea that "it is crucial to create a basis for agreement among the various sectors of Jewish society, finding a workable joint path and entrenching it in legislation." ${ }^{, 23}$ Earlier, in 2001, another initiative, called the Kineret Covenant, was adopted by a group of Israeli citizens (all Jewish) who called themselves the Forum for National Responsibility. ${ }^{24}$ This initiative was more elaborate and was not limited to the relationship between religious and non-religious Jews. It dealt with questions related to democracy and the identity of the state. In both initiatives Palestinian citizens were not included in the discussions. While the Gavison-Medan Covenant was presented as an intra-Jewish discussion on religion-related matters (although it touched on many aspects that affect everyone in Israel), and hence the inclusion of Jews only, limiting the Kineret Covenant to Zionist Jews only was justified stating that there should be an intra-Jewish discussion first, and then discussion with the Arab citizens will follow. ${ }^{25}$ A third initiative, Constitution by Consensus, was a process promoted by the Israeli Democracy Institute to achieve a constitution with broad consent. The "broad consent" did not include any Palestinian citizens of Israel in the drafting committee, although it included Palestinian citizens in some of the discussions. ${ }^{26}$ The general approach in these initiatives reflects a view that sees the social

\footnotetext{
22 "About the Covenant", online: The Gavison-Medan Covenant <http://www.gavisonmedan.org.il/english/about/>.

${ }^{23}$ Ibid.

24 "Kineret Covenant", online: <http://www.hofesh.org.il/yoman/02/amanat kinneret.html>.

25 Vered Levi-Barzilai, "In Tiberias We Defined the State of the Jews" Haaretz (1 January 2002) online: <http://www.haaretz.co.il/misc/1.760918> (in Hebrew).

${ }^{26}$ See Nadim Rouhana, "'Constitution by Consensus': By Whose Consensus" (November 2004) 7 Adalah'a Newsletter online: <http://www.adalah.org/newsletter/eng/nov04/arl.pdf> Rouhana, "Constitution by Consensus"]; Amir Abramovitz, "Constitution by Consensus, Including, Certainly, the Consensus of the Arab Minority in Israel" (November 2004) 8 Adalah's Newsletter online: <http://www.adalah.org/newsletter/eng/dec04/IDIresponse.doc>; Nadim Rouhana, "The Jewish Institute for Ethnic Democracy" (January 2005) 9 Adalah's Newsletter online: <http://www.adalah.org/newsletter/eng/jan05/ar3.pdf> [Rouhana, "The Jewish Institute"]; Baruch
} 
contract as limited to Jewish citizens only. Only their consent is needed and sought. This exclusion is not limited to the Palestinian citizens, as Aeyal Gross has observed; other groups, such as gays and lesbians were also excluded. ${ }^{27}$

\subsection{Basic Norm Theory}

The basic norm theory comes in two variations in Israeli constitutional law. The first variation is based on Kelsen's grundnorm. It is technical in nature and its sole function is to authorize the creation of the first constitution. In Bank Mizrabi, Barak locates Israel's Kelsenian basic norm in the Declaration of Independence where it was declared "that the Temporary State Council is the highest authority in the State of Israel." ${ }^{28}$ Like Kelsen's basic norm, this norm identified by Barak does not provide any indication of who the People is. If we are to stay loyal to Kelsen's conception of the basic norm and its function, then the inquiry should stop here, for the basic norm does not, and should not explain who the People is. It just provides for the normativity of the "first constitution" so as to avoid a situation of deriving this normativity from facts. Even though the basic norm does not identify who the People is, it nonetheless useful to note Barak's application of the theory. The way it was applied points in the direction of the Declaration of Independence which spoke in the name of the "the Jewish Community of Eretz-Israel and of the Zionist movement". The Declaration and its role and interpretation will be discussed at length in the next section.

The second variation of the basic norm theory, however, provides more insights. It entails substantive elements which include the basic principles of the legal system such as the

Kimmerling, “Constitution or Prostitution?” January 2005) 9 Adalah's Newsletter online: <www.adalah.org/newsletter/eng/jan05/ar1.pdf>.

27 Aeyal Gross, "A Constitution for Israel: With Whose Consent and at Whose Expense" January 2005) 9 Adalah's Newsletter online: <http://adalah.org/newsletter/eng/jan05/ar2.pdf>.

${ }^{28}$ Bank Mizrabi, supra note 1 at 356. 
rule of law, respect for human rights, freedom and equality. Rubenstein and Medina, who support this approach, link it to the "material constitution" - norms and principles that are not part of the "formal constitution", but are nonetheless part of the constitutional regime. ${ }^{29}$ The Jewish and democratic definition is seen as part of the basic norm in this sense. Although this understanding of the basic norm does not follow Kelsen's understanding of the concept and its function in the constitutional edifice, and could even be seen as a misnomer, it insinuates a fundamental principle that is supra-constitutional. In this sense, one can relate it to other terms that were used to describe the Jewish essence of the state which tie this essence to the very existence of the state and placing it at the highest normative level. Examples of these terms include "axiom" 30 - implying a philosophical starting point that there is universally accepted and not to be questioned - and "genetic code"31 which implies a naturally occurring situation that dictates the nature of the whole body it is part of and that is almost impossible to change. One may wonder here who adopted the Jewishness of the state as a basic norm, or an axiom, or genetic code, and if it is the People, then who is included in this category. While these concepts do not explain who the People is, they do provide some indications by emphasizing the Jewish character.

\subsection{Israeli Nation v. Israeli People?}

The national/ethnic belonging of every Israeli citizen and resident is registered in the Population Registry, and until 2002 it was also stated in the identification cards issued by the state that all residents are obliged to carry by law. For Jewish Israelis the nation (or nationality)

\footnotetext{
29 Amnon Rubenstein \& Barak Medina, Constitutional Law of the State of Israel (in Hebrew), 6th ed, (Jerusalem: Schocken Publishing House, 2005) vol 1 at 71-72.

${ }^{30}$ Tibi, supra note 2 at 21.

${ }^{31}$ Ibid.
} 
is registered as Jewish if the person satisfies the requirements of the definition of "Jew" in the Law of Return (whoever was born to a Jewish mother, or converted to Judaism, and does not belong to any other religion). Arab citizens are usually registered as "Arabs" or "Druze" depending on their religious affiliation. "Israeli" as a national category does not exist. Dissatisfaction with this situation, and with the religious definition of the Jewish nation, has led to two legal challenges where the discussion focused on the question of whether an Israeli nation exists. In both cases the answer was negative.

As early as 1972, the Supreme Court rejected an appeal by a citizen who was registered as Jewish to change his registration to Israeli. The Court stated that there is no such thing as an Israeli nation. The appellant could not be registered as Israeli since he did not prove the existence of an Israeli nation that is distinct and separate from the Jewish nation. ${ }^{32}$ In 2008 , a group of citizens petitioned the Jerusalem District Court demanding a declaration that their national belonging is "Israeli". They sought this declaration in order to change their status in the Population Registry. The Court rejected their request stating that "a declaration regarding the existence of an Israeli nation has significant implications for the identity of the State of Israel; in its [Israel's] eyes, in the eyes of its citizens and residents, and in the eyes of the Jewish people in the diaspora, and in the eyes of the nations of the world." ${ }^{33}$ In their argument in favor of rejecting the request, the Attorney General and the Ministry of Interior went as far as saying that if an Israeli nation is recognized, this will have decisive consequences for the character of the state as the state of the Jewish people to the point that this determination will

${ }^{32}$ CA 630/70 Tamarin v. The State of Israel (1972), IsrSC 26(1) (in Hebrew).

${ }^{33} \mathrm{HP}$ (Jerusalem) 6092/07 Oman v. Ministry of Interior (2008) at para. 44 [pending appeal] [translated by author]. 
contradict Israel's definition as a Jewish and democratic state. ${ }^{34}$ In both decisions the Courts linked the issue of the existence of a nation to the concept of self-determination signaling that such recognition may affect Jewish self-determination.

The rejection of the idea that there is an Israeli nation signifies the rejection of the idea that all citizens in Israel are equal participants in a self-determining unit in the form of the state. Self-determination in Israel is restricted to the Jewish nation only. The consistency of this rejection over a long period of time also means a rejection of the idea that a shared national political identity can grow out of the recognition of a plurinational sociological reality. These cases however do not adequately explain the implications of the exclusion of the Palestinian citizens from the right to self-determination in the state. They do not provide clear answers about the nature of the relationship between the citizens and the state and if this citizenship is, as a matter of law, equal and uniform for all citizens.

None of the approaches reviewed above provide a conclusive answer about who is the People in Israel. In order to do so, the following chapters will examine the question of the People through an inquiry into the locus of ultimate political power (or sovereignty) through the prism of the constituted form. This examination will start with the founding moment and the first legal text issued in Israel.

\section{Beginnings: The Declaration of Independence}

The query of "who is the People?" will begin with the first act of the state: the Declaration of the Establishment of the State of Israel, also known as the Declaration of Independence. The Declaration took place shortly before the official creation of the state. The signing

34 Ibid at para. 40 . 
ceremony took place in the afternoon of 14 May 1948 and the Declaration itself entered into force with the expiry of the British Mandate over Palestine at midnight of the same day. ${ }^{35}$ Before I move on to discuss the Declaration, it is helpful to provide some background about the unique circumstances in which it was made.

In November 1947, the United Nations General Assembly issued its resolution number 181 calling for the partition of Palestine into an "Arab state" and a "Jewish state". The plan included detailed provisions about the future states, including boundaries and the transition from the Mandate to statehood. Section C of Part I of the plan included stipulations that should be included in a declaration to be made to the United Nations before independence. These stipulations were to become "fundamental laws of the State". As is well known, the Partition Plan was rejected by the Palestinian Arabs and the Arab states, and violence between Palestinian Arab volunteer militias supported by volunteers from other neighboring countries, and Zionist paramilitary groups (mainly the Hagana which became the Israeli Defense Army) ensued. The rejection of the plan was so forceful and consistent that it seemed that the Plan would be abandoned or changed. ${ }^{36}$ In April 1948 the United Kingdom announced that it would be withdrawing its troops (and thus effectively ending the Mandate) on 15 May 1948, two and half months earlier than the 1 August timeline according to the Partition Plan. The Declaration of Independence was drafted under these circumstances in April/May of 1948 in partial fulfillment of the "declaration" requirement of the Plan. ${ }^{37}$

\footnotetext{
35 See Annex " $A$ " for an English language translation of the Declaration [the Declaration].

36 Victor Kattan, From Coexistence to Conquest: Intermational Law and the Origins of the Arab-Israeli Conflict, 1891-1949 (London: Pluto Press, 2009) at 166.

37 Yoram Shahar, "Earlier Drafts of the Declaration of Independence" (in Hebrew) (2002) 26:2 Iyunei Mishpat 523.
} 
As in the case with declarations of independence in other states, Israel's Declaration is one of the main constitutional texts. Even though it is not applied directly by courts like legislation, it is a relevant constitutional document, and it has gained more prominence as a constitutional text after the enactment of Basic Law: Human Dignity and Freedom (1992), and Basic Law: Freedom of Occupation (1992). Both basic laws refer to the "spirit of the principles set forth in the Declaration" as a reference point for upholding human rights. ${ }^{38}$ In this section, I will examine the conception of the People as reflected in the Declaration. I will begin with a textual interpretation of the Declaration to examine who is the "we" that speaks. Then I will move on to discuss the treatment of the would-be Arab citizens of the Jewish state in the text. I will end by discussing the current legal status of the Declaration.

\section{1. "We Hereby Declare"}

In his analysis of a draft of the American Declaration of Independence, Jacques Derrida wonders about the question of "who signs, and with what so-called proper name, the declarative act which founds an institution?" 39 Derrida resolves this puzzle with another one- "[ $[$ ]he 'we' of the declaration speaks in the name of the people." ${ }^{40}$ But as he observes, "this people does not exist. They do not exist as an entity. It does not exist, before this declaration, not as such."41 Here " $[t]$ he signature invents the signer." 42 This implies a process of invention and transformation that the People goes through, with the signing being one of the most critical stages. Did the

\footnotetext{
${ }^{38} \mathrm{~S} .1$ of both Basic Laws is identical: "Fundamental human rights in Israel are founded upon recognition of the value of the human being, the sanctity of human life, and the principle that all persons are free; these rights shall be upheld in the spirit of the principles set forth in the Declaration of the Establishment of the State of Israel."

${ }^{39}$ Jacques Derrida, "Declarations of Independence" (1986) 7:1 New Political Science 7 at 8 [emphasis in original].

40 Ibid at 10.

${ }^{41}$ Ibid.

42 Ibid.
} 
signature in the case of the Declaration of Independence of Israel create a "we" that spoke for the People? Who was the "we" or the People?

The document could be divided into three parts. The first part chronicles a brief history of the Jewish people, Eretz Yisrael (which translates into Land of Israel and refers to historic Palestine), and the Zionist movement, and summons the moral and legal authorities in support of the creation of the Jewish state. These authorities include the Balfour Declaration, the Deed of Mandate and the 1947 Partition Plan, in addition to the law of nature and the right to self-determination. The second part is the declaratory one where the state is declared to the world. The third part sets out some of the practical and legal arrangements which would accompany the creation of the state or would follow shortly after. It also includes general statements about the character of the state and about the relations with the Palestinian residents, neighboring states and the world.

The Declaration's "we" is very clear. In the declaratory paragraphs of Declaration, after affirming that the creation of the state as an expression of "the natural right of the Jewish people to be masters of their own fate, like all other nations, in their own sovereign State", ${ }^{43}$ it went on to state that:

Accordingly we, members of the People's Council, representatives of the Jewish Community of Eretz-Israel and of the Zionist movement, are here assembled on the day of the termination of the British Mandate over Eretz-Israel and, by virtue of our natural and historic right and on the strength of the resolution of the United Nations General Assembly, hereby declare the establishment of a Jewish State in Eretz-Israel to be known as the State of Israel. ${ }^{44}$

As noted by authors such as Orit Kamir and Raef Zreik, "we" refers here to the members of the People's Council representing "the Jewish Community of Eretz-Israel" and the Zionist

43 The Declaration, supra note 35 at para. 10.

44 Ibid at para. 11 [emphasis added]. 
movement. ${ }^{45}$ The collective that is being invented here, to borrow Derrida's formulation, is made of the Jewish community in Mandate Palestine and those who belong to the Zionist movement. This is the People. Accordingly, all of those who signed the Declaration were Jewish (mostly male and Ashkenazi) and indeed were notable members of the Jewish community. Four paragraphs below this paragraph, the newly created state calls on the United Nations "to assist the Jewish people in the building-up of its State". "We" in this sense is broader, and includes the Jewish people in its totality.

This observation about "we" is further supported by paragraph 16 of the Declaration which states that

[w] appeal - in the very midst of the onslaught launched against us now for months - to the Arab inhabitants of the State of Israel to preserve peace and participate in the upbuilding of the State on the basis of full and equal citizenship and due representation in all its provisional and permanent institutions. ${ }^{47}$

This oft-quoted paragraph is seen as one of the normative sources of equality in Israeli law as it offers "full and equal citizenship". ${ }^{48}$ However, in addition to this appeal, this paragraph also creates, or at least reinforces, the conception of the emerging People of the state as exclusively Jewish. It created the dichotomy of the we/you, where "we" are the sovereign People who, by virtue of this sovereignty, can offer "you" - the "Other" - citizenship and equality. It is important to note here that it is not citizenship as of right based on habitual residence according to the rules of state succession in international law or according to the Partition

\footnotetext{
${ }^{45}$ Orit Kamir, "The Declaration [of Independence] Has Two Faces: The Zionist Declaration and the Democratic Declaration" (in Hebrew) (1999) 23 Iyunei Mishpat, 473 at 513; Raef Zreik, "The Persistence of the Exception: Some Remarks on the Story of Israeli Constitutionalism" in Ronit Lentin, ed, Thinking Palestine (London: Zed Books, 2008) 131 at 140.

46 The Declaration, supra note 35 at para. 15.

${ }^{47}$ Ibid.

${ }^{48}$ See e.g. HCJ 1113/99 Adalab- The Legal Center for the Rights of the Arab Minority in Israel v. Minister of Religious Affairs (2000), IsrSC 54(2) 164 at 170 [Adalab]; HCJ 6698/96 'Adel Ka'dan v. Land Administration of Israel (2000), IstSC 54 (1) 258 at para. 31 [Ka'dan].
} 
Plan, for if this were the case, then the "Arab inhabitants of the State of Israel" would automatically be seen as citizens. Nor is it citizenship based on a "natural and historic right", similar to the rights mentioned in the Declaration as belonging to the Jewish people and cited as the underlying of the state. It is a citizenship that "we" will "give" to "you" if you "preserve the peace". It is a conditional offer of inclusion and equality if "the peace" is preserved.

In this context, it is insightful to highlight two points that would provide more context to better understand the "we/you" or "we/Other" dichotomy. It is reasonable to view the invitation to join the state on the basis of equal citizenship as a positive gesture and as a sign of commitment to equality, as it is often perceived by the Court and in the academic literature. ${ }^{49}$ This gesture, however, should be assessed against two important points. The first point is the composition of the population in the area that was assigned to the Jewish state according to the 1947 Partition Plan which is seen as one of the bases of the Declaration. According to the report of the United Nations Special Committee on Palestine (UNSCOP) from September $1947,49.9 \%$ of the population in the area designated for the Jewish state was Palestinian Arab in 1947. ${ }^{50}$ Thus, the Declaration does not include $49.9 \%$ of the population in the People but invites, after the fact, and conditionally, to join as citizens. Those who are not

\footnotetext{
49 Adalah, supra note 48; Ka'dan, supra note 48. See also, Amnon Rubenstein, "The Knesset and the Basic Laws on Human Rights" (in Hebrew) (2000) 5 Mishpat o Mimshal 339; Amnon Rubenstein \& Liav Orgad, "The Preamble to the Constitution and its Legal Status: The Case of Israel" (in Hebrew) (2007) 11 HaMishpat 79.

50 The UNSCOP Report used the official numbers for late 1946. According to the Report, at the end of 1946, the area allocated to the Jewish state would have the population of 498,000 Jews, and 497,000 Arabs, including 90,000 Bedouins, bringing the total percentage of Arabs to $49.9 \%$. See United Nations Special Committee on Palestine: Report to the General Assembly (3 September 1947) A/364 (1947). Based on information provided by the representative of the United Kingdom during the debates on the Partition Plan, the numbers that UNSCOP adopted were inaccurate in that they did not include many of the Bedouin population. If the numbers are adjusted accordingly, $50.5 \%$ of the population in the Jewish state would have been Arab. See Ad Hoc Committee on the Palestinian Question: Report of Sub-Committee 2, (11 November 1947) A/AC.14/32 (1947) at para. 64 ("It will thus be seen that the proposed Jewish State will contain a total population of $1,008,800$, consisting of 509,780 Arabs and 499,020 Jews. In other words, at the outset, the Arabs will have a majority in the proposed Jewish State').
} 
part of the "we" are a little less than the majority of the population if not the majority. The second point that should be highlighted is that by the time the Declaration was made, about 300,000 Palestinians had been expelled or fled from the areas which were under the control of the embryonic state as part of a wider process which has been described as ethnic cleansing. ${ }^{51}$ At the same time the text of the Declaration was offering conditional citizenship and equal rights to the Palestinians, military and para-military groups that answered to the signers of the Declaration were actively working on expelling them. About $78-85 \%$ of the Palestinians who were in the areas that fell under Israeli control had been expelled or fled by the end of the war in $1949 .^{52}$

More indications about the identity of the People can be found throughout the Declaration. In the first part, for example, the Declaration describes the history of the Jewish people and the significance of Eretz Yisrael (Palestine) for them. The history here is not of the geographical area, but of a trans-territorial Jewish people. It is described as a community trying to re-establish its state creating the impression that it seeks to do so in a vacant land. Indeed, as Orit Kamir observes, as a literary text, the Declaration empties the land from the majority of its inhabitants (the Palestinians), which is in line with other literary Zionist texts from that era. ${ }^{53}$ In essence, it paints a picture of the land as terra nullius. The Palestinians, or the "Arabs of Eretz Yisrael" as the Declaration calls them, are not part of the history of the land but are only part of a present when they plunge into the last parts of the text in the form of

51 See Benny Morris, The Birth of the Palestinian Refugee Problem Revisited (Cambridge: Cambridge University Press, 2004); Ilan Pappe, The Ethric Cleansing of Palestine (Oxford: One World, 2007).

52 These percentages could be derived from the statistics on Palestinian refugees and Palestinians who stayed in what became Israel. The number of Palestinians who stayed in Israel in 1949 was around 160,000. The number of Palestinian refugees, ranges, according to the source cited, from $600,000-900,000$, with 726,000 being the most authoritative number adopted by the UN in 1949. See The Final Report of the United Nations Economic Survey Mission for the Middle East, 28 December 1949.

${ }^{53}$ Supra note 45 at 498. 
assailants. ${ }^{54}$ And when they do enter the text, they are presented as merely passive "inhabitants", as opposed to the active Jewish pioneers who are

defiant returnees and defender, they made deserts bloom, revived the Hebrew language, built villages and towns, and created a thriving community controlling its own economy and culture, loving peace but knowing how to defend itself, bringing the blessings of progress to all the country's inhabitants, and aspiring towards independent nationhood. 55

Similarly, most of the values and principles referred to - such as "Jewish immigration", "Ingathering of the Exiles" and the "redemption of Israel" - are Zionist principles and ideals which to a large extent clash with the interests of a significant part of the population. One may question whether the reference to the more universal principles - such as the reference to "complete equality of social and political rights to all its inhabitants irrespective of religion, race or sex" and the guarantees of "freedom of religion, conscience, language, education and culture" - are enough to bring the Palestinians within the scope of the People. For these rights and principles are important even in a homogenous polity, and are the very substance of declarations of independence. This reference to universal values seems to be more motivated by the need to bring the Declaration as much as possible within the requirements of the Partition Plan, and in any event, these provisions were not seen as binding on the state as will be explained in the next section. ${ }^{56}$

The fact that the sovereign People in the Declaration is restricted to the Jewish people has been noticed by commentators. ${ }^{57}$ While Kamir sees it as one of the flaws of the Zionist aspect of the Declaration, Rubenstein and Orgad see it as a matter that could be rectified with some textual changes. The exclusive emphasis on the Jewish people and Jewish history in the

54 The Declaration, supra note 35 at para. 15.

55 The Declaration, supra note 35 at para. 3.

${ }^{56} \mathrm{Kamir}$, supra note 45 at 513.

57 Ibid at 499-500; Rubenstein \& Orgad, supra note 49 at 107. 
Declaration could be remedied by mentioning that the Jewish and democratic state will "respect the Arab national minority and other minorities." ${ }^{\text {" W }}$ While it is doubtful that such as a minor textual change is enough to address the flaws on the textual and symbolic level, this suggestion raises more significant problems when it comes to legal questions, which will be discussed below.

\subsection{The Legal Status of the Declaration}

According to Section $C$ of the Partition Plan, the Declaration was supposed to include stipulations about the protection of human rights of the citizens of the "Jewish" and "Arab" states, especially the right to equality and religious, cultural and minority rights. These stipulations were to be "recognized as fundamental laws of the State and no law, regulation or official action shall conflict or interfere with these stipulations, nor shall any law, regulation or official action prevail over them". ${ }^{59}$ The Supreme Court of Israel did not follow this route in interpreting the Declaration, and it did not see these requirements as part of the constitution or constitutional law. Accordingly, the universal rights and values mentioned in it were not seen as sources that could impose legal limits on the powers of the different branches of the state. In cases that were decided as early as 1948, the Supreme Court ruled that the Declaration is meant to announce the creation of the state as a matter of international law. While it does express "the people's vision and its 'I believe", 60 it is not a constitutional law that regulates the validity of legislation. With the passage of time, the status of the Declaration evolved, and it is now considered to play a role in the process of interpretation of legislation

58 Ibid at 108 .

${ }^{59}$ Section C. of Part I of UNGA 181 (1947).

${ }^{60} \mathrm{HCJ} 10 / 48$ Zeev v. Officer in Charge the Tel-Aviv Urban Area (1948), IsrSC 185 at 89 (in Hebrew) [translated by author]. 
for it is seen as an expression of the nature of the state. ${ }^{61}$ It is seen as "anchoring the basic principles of the regime" and includes a number of principles that are foundational. ${ }^{62}$ Thus, based on the spirit of the Declaration, a number of rights and freedoms were recognized as part of Israeli law, such as the right to freedom of expression and equality. These rights and principles were recognized in cases of judicial review of administrative actions only. Legislation was immune from judicial review based on the principles enshrined in the Declaration. The Declaration was not seen as an independent source of constitutional rights. ${ }^{63}$ As mentioned above, the Declaration gained more prominence with the enactment of the basic laws that stated that rights should be upheld in the spirit of the Declaration.

The principles and values in the Declaration are not limited to the universal values of human rights and equality. As Barak says, the principles include " $[t]$ he connection between the Land and the Jewish people, the right of the [Jewish] people over the Land, the revival of the Hebrew Language and the striving for peace." ${ }^{64}$ The Declaration therefore does not only serve as an interpretative tool for the promotion of human rights. At times it also served as a tool to deny them. It is in these cases that the People that the Declaration creates becomes most obvious and its "will" could be seen in action in the form of the basic principles of the legal system. In the language of Justice Chechin, "[i]n extraordinary battles and events, it is possible that the basic principles ascend from depths like an exploding volcano or a hot geyser, and as

61 Rubenstein \& Medina, supra note 29 at 40.

${ }^{62}$ HCJ 153/87 Shakdi'el v. Minister of Religious Affairs (1988), IsrSC 42 (2) 221at 275 (in Hebrew) [shakdi'e] [translated by author].

${ }^{63} \mathrm{See} \mathrm{HCJ} 73 / 53 \mathrm{Kol} \mathrm{Ha}$ Am v. Minister of Interior (1953), IsrSC 7(2) 871 (in Hebrew); Kamir, supra note 45 at 522. ${ }^{64}$ Aharon Barak, Interpretation in Law (in Hebrew) (Jerusalem: Nevo Publishing, 1994) vol 3 at 306 [translated by author]. 
they [the basic principles] penetrate the constitution and the law, they directly decide the hot question that found its way to the door of the Court."

The prime example where the basic principles emanating from the Declaration were used is the 1965 ruling in the case of Yerdor v. Central Election Committee for the Sixth Knesset. ${ }^{66}$ In this case the Supreme Court relied on the principles in the Declaration to affirm a decision by the Central Elections Committee prohibiting candidates from participating in the elections despite the absence of statutory authority for taking this action. The disqualified slate, known as "the Socialist List", included members of the Arab $A l-A r d^{67}$ organization which was declared an illegal organization for sympathizing with Arab nationalism and calling for a just solution to the Palestine problem consistent with the right to self-determination of the Palestinian people. ${ }^{68}$ In his opinion, then Chief Justice Agranat stated that in order to examine whether the Elections Committee was authorized to bar $A l-A r d$ 's participation, a number of constitutional facts, or "constitutional givens" as Agranat called them, should be emphasized. Quoting the Declaration, he stated that there is no doubt that

not only is Israel sovereign, independent, and freedom-seeking and characterized by a regime of the rule of the people, but it was also created 'as a Jewish state in Eretz Yesre'l' [and there is not doubt] that the act of its creation was carried out, first and foremost, by virtue of 'the natural and historic right of the Jewish people to live, like all other peoples, standing in its own right in its sovereign state, [and there is no doubt] that this act embodied the ambitions of the generations for the redemption of Israel', 69

\footnotetext{
${ }^{65}$ Movement for the Quality of Governance, supra note 2 at para. 11 (opinion of Deputy Chief Justice Chechin) [translated by author]. While this is a minority opinion, the disagreement is not on importance of the basic principles but on the methods of application- the direct use of these principles should be means of last resort.

66 Yerdor, supra note 5.

67 Al-Ard means "the land" in Arabic.

${ }^{68}$ It should be highlighted that the only illegal activity that members of this group were convicted of was publishing a newspaper without the necessary permits. Apart from that, they were never found guilty of any "security" offence. See Pnina Lahav, Judgement in Jerusalem: Chief Justice Simon Agranat and the Zionist Century (Berkeley: University of California Press, 1997) at 188.

${ }^{69}$ Yerdor, supra note 5 at 385 [translated by author].
} 
Based on this constitutional fact, Agranat concluded that no authority could exercise its power in a manner that questions the existence or the eternality of the state, and therefore, the Committee was acting within its powers when it barred the slate from participating in the elections. ${ }^{70}$ To support this argument, Agranat tried to summon more moral authority by mentioning that any other conclusion would be a disparagement of the two wars that Israel fought with the Arab states and of the killing of millions of Jews in the Holocaust which proved, quoting the Declaration, "the urgency of solving the problem of its homelessness by re-establishing in Eretz-Israel the Jewish State”.

The result was that the Jewish character of the state, included in the text and spirit of the Declaration, was used to deny a democratic right even with the absence of legislation authorizing the Committee to do so. The majority opinion here deviated from the classic formalism of the Court and used the Declaration to justify the outcome. ${ }^{71}$ In this sense, one can argue that the right to participate in the elections is contingent on accepting the Jewish nature of the state, a requirement that was later introduced in $1985 .{ }^{72}$ In this case, the Jewish character of the state trumped democracy and the rule of law in its formal sense.

It would prove insightful to compare the Yerdor ruling with the opinion in a later case where the Supreme Court discussed the decision of the Central Elections Committee to disqualify Meir Kahane from participating in the elections because of his explicitly racist platform, and to disqualify the Progressive List for Peace because its leader was previously

\footnotetext{
70 This case was decided in 1965, prior to the amendment to Basic Law the Knesset which prohibits the participation in the elections if the party or candidate negate the existence of the state as the state of the Jewish people. This was only enacted in 1985 and then amended to "Jewish and democratic state".

71 The minority Justice, Chaim Cohen, stuck to the formalist approach that absent an explicit statutory provision the Committee could not restrict participation.

72 For a detailed discussion of this issue and subsequent case law, see chapter $\mathrm{V}$ which deals with issues of political representation.
} 
affiliated with the $A l-A r d$ movement. ${ }^{73}$ At that time, in 1984, the Committee still lacked the authority to disqualify parties from participating in elections, but, resorting to the Declaration, it went ahead and disqualified Kahane and the Progressive List, the former for upholding racist and anti-democratic principles and the latter for undermining the existence of the state and preserving its Jewish distinctiveness. The Supreme Court, reaffirming the rule that was first decided in Yerdor, accepted both appeals and allowed both slates to participate in the elections. But while it explicitly stated that the Committee was not authorized to disqualify candidates based on racism or anti-democratic platforms, and thus allowed Kahane to participate, the Court stated that the rule decided in Yerdor is still valid, and it only allowed the Progressive List's participation because of a lack of evidence that it was the continuation of $\mathrm{Al}$ Ard. In essence, the principles of the Declaration dealing with justice and equal rights (democracy was not mentioned in the Declaration) were not as significant as the principles enshrining the Jewish character. Among all of the principles that are mentioned in or derived from the Declaration, only the Jewish character was strong enough to allow deviation from formal legal provisions.

Comparing these two cases where the Declaration's values played a role gives us an indication about who is considered the People that authored this declaration, not only from the point of view of textual analysis, but from the point of view of the law. While the universal values are used as references and celebrated by the Court and academics, in serious cases the universal values are subordinated to the particular Jewish values, demonstrating who the People is.

${ }^{73}$ EA 2/84 Neiman v. Chairman of the Central Elections Committee for the Eleventh Knesset (1985), IsrSC 39(2) 225 (in Hebrew). 


\subsection{The Declaration and the Prospects of Constitutional Change}

The Declaration also has implications for the potential of future constitutional change. In addition to the interpretive role of the Declaration and its principles, Barak sees the Declaration as one of the sources of authority to make a constitution. As he sees it, this authority could only be exercised in a manner that gives expression to the basic beliefs and values of Israeli society as set out in the Declaration. ${ }^{74}$ The authority of the Knesset to enact basic laws or a full constitution is restricted by those principles. Barak gives two examples to demonstrate the limits of the authority of the Knesset as a constituent body based on the Declaration, namely the democratic character and the Jewish character and the link to the Jewish people. ${ }^{75}$ The implications of this position for sovereignty, constituent power and the idea of the People will be discussed at length in chapter VI, but at the this point I want to highlight the role that the Declaration plays in shaping this view. Any constitutional change cannot go beyond or challenge the principles set out in the Declaration.

Barak's position on the status and role of the Declaration seems to be widely accepted. As mentioned above, one of the most serious attempts to discuss and design a constitution for Israel was the attempt spearheaded by the Israel Democracy Institute and later on discussed by the Knesset's Constitution, Law, and Justice Committee. The initiators of this proposal suggested the use of the Declaration as the preamble for the Constitution. ${ }^{76}$ The

\footnotetext{
74 Bendor \& Segal, supra note 20 at 144; Movement for the Quality of Governance in Israel, supra note 2 at para. 74 (opinion of Chief Justice Barak). In this case Barak stated that a basic law changing the Jewish and democratic character of the state is not within the scope of authority of the Knesset. He does not explicitly anchor this authority in the Declaration but in the "basic principles of the system". Elsewhere he stated that those are based on the Declaration, see Shakdi'el, supra note 62.

${ }^{75}$ Bendor \& Segal, supra note 20 at 145.

${ }^{76} \mathrm{See}$ "Constitution by Consensus: Proposed by the Israel Democracy Institute Under the Leadership of Justice Meir Shamgar" (Jerusalem: Israel Democracy Institute, 2007), online: < http://en.idi.org.il/media/1529178/ConstitutionByConsensus_Draft.pdf $>$.
} 
Declaration here, as Prof. Aviezer Ravitzky (one of the authors of this draft constitution) explains, is meant to be "a prime ideological pronouncement. It is not derived from legal discourse, but rather is imposed upon it, framing it with a super-structure". ${ }^{77}$ Rubenstein and Orgad also support the inclusion of the Declaration, by way of reference, as part of the preamble of any future constitution. This position is premised on the historical importance of the Declaration, on the legal importance of the Declaration which anchors important universal principles and values, and on the idea that it enjoys consensus among most Israeli citizens (Palestinian citizens included). ${ }^{78}$ The only evidence that Orgad and Rubenstein provide to support this assertion is a reference to the Israeli Democracy Institute "Constitution by Consensus" document. The document, which includes the draft constitution and the opinions of the authors, was written solely by Jewish Israelis, although some Palestinians were included in some consultations. Not only was the document rejected and criticized by many individuals and organizations, ${ }^{79}$ it also triggered a counter-current among the Palestinians intelligentsia. As a response to this initiative, a number of civil society organizations issued position papers explaining their vision about the state and its relationship with the Palestinian minority. While these documents included a long list of values such as democracy, equality, reconciliation, and

77 Ibid at 83. While he goes on to add that "interestingly enough, even the Arab members of Knesset did not reject the idea", another co-author of the draft constitution, Amir Avramovitz, states in the same document that: I estimate that a large portion of the elected Arab leadership in Israel, and especially the majority of Arab Knesset members, would find it difficult to support, officially and publicly, a constitution which defines Israel as "Jewish and democratic," a constitution whose introduction is the Declaration of Independence, and whose symbols are Jewish and Zionist ones. It will be difficult for them to identify with such an arrangement, and they would be concerned that their very support would grant de facto legitimacy to Zionism and to its result, which is perceived in their eyes as a "nakba," a national catastrophe." (Ibid at 39-40).

${ }^{78}$ Rubenstein \& Orgad, supra note 49 at 106.

79 See Rouhana, "Constitution by Consensus" supra note 26; Abramovitz, supra note 26; Rouhana, "The Jewish Institute", supra note 26; Kimmerling, supra note 26. 
multiculturalism to name a few, unsurprisingly, they did not include any reference to the Declaration. ${ }^{80}$

While the Israel Democracy Institute draft constitution adopts the Declaration as a preamble without any changes, Rubenstein and Orgad suggest some additions to the preamble. They suggest adding the Jewish and democratic definition of the state (since it was not mentioned in the Declaration), and a minor textual addition mentioning the Palestinian minority. ${ }^{81}$ They assert that this is enough to address the flaws in the text of the Declaration which limit sovereignty to Jews only, and will rectify the problem that all the signatories were Jewish with no Arabs. ${ }^{82}$ They are opposed to opening the text of the Declaration to changes and argue that this will likely lead to many disputes making agreement hard to achieve. The problem with this argument is that it assumes broad agreement with the existing text, and prefers it to a new text to be agreed on. This assumed broad agreement is not supported by evidence especially when it comes to the Palestinian citizens. It seems that Rubenstein and Orgad do not seek to achieve a consensus or even a broad agreement, but merely want to make minor cosmetic changes. This suggestion of upgrading the Declaration to make it part of the preamble of the constitution (in effect part of the constitution), which is accompanied by an unwillingness to open the text of the Declaration to changes, while at the same time

80 "The Future Vision of the Palestinian Arabs in Israel" (Nazareth: The National Committee of the Heads of the Arab Local Authorities, 2006), online: < http://www.adalah.org/newsletter/eng/dec06/tasawormostaqbali.pdf>; "The Haifa Declaration" (Haifa: Mada al Carmel, 2007), online: <http://madaresearch.org/en/files/2007/09/haifaenglish.pdf>; "The Democratic Constitution" (Haifa: Adalah, The Legal Center for Arab Minority Rights in Israel, 2007), online: <http://adalah.org/Public/files/democratic constitution-english.pdf>.

${ }^{81}$ Rubenstein \& Orgad, supra note 49 at 108. The following is what they suggest as a preamble: "The constitution of the State of Israel is based on the recognition of the value of the human being, the sanctity of his life, and his freedom, and it [the constitution] will be respected in the spirit of the principles that are in the Declaration of the Establishment of the State of Israel, as a Jewish and democratic state, as well as respecting the Arab national minority and additional minorities that dwell in Israel." [translated by author].

${ }^{82}$ Ibid at 107. 
emphasizing the Jewish and democratic definition of the state, in essence empties the process of constitutional change from its transformative potential. Instead of looking at the process of constitutional change as a moment of renewal or a new beginning that carries an emancipatory potential, it becomes a matter of reinforcing existing flaws. Adopting minor textual additions in this context is rendered useless by insisting on the Declaration as the anchor, and the emphasis on the Jewish and democratic definition.

This position that situates the Declaration with its ethnocentric emphasis at the centre of the constitutional regime and as a starting point for constitutional change is, as Hassan Jabareen observes, contrary to the global trend in terms of preambles to new constitutions. ${ }^{83}$ The trend in the past three decades highlights human rights discourse, as opposed to the ethnic emphasis in preambles to constitutions. Jabareen further argues that the Declaration, instead of being a tool or symbol of reconciliation in a new constitution, further celebrates and congeals the moment of the beginning of the Palestinian Nakba, thus reinforcing the victory of the Israeli society over the native population. Constitutional change could potentially be transformative and a part of a reconciliation process. For this to happen, it should facilitate transition as part of political change. Such constitutions, as Ruti Teitel explains, should be "simultaneously backward- and forward-looking" ${ }^{84}$ The insistence on looking backwards, to the violent founding moment, and seeing it as anchoring the constitution, is a barrier to transformation and transition. In this sense these proposals for a

\footnotetext{
${ }^{83}$ Hassan Jabareen, "The Constitutional Conception of the 'Jewish and Democratic' State" in Honaida Ghanim \& Antwane Shalhat, eds, The Meaning of a Jewish State (in Arabic) (Ramallah: MADAR The Palestinian Forum for Israeli Studies, 2011) at 38-39.

${ }^{84}$ Ruti Teitel, Transitional Justice (Oxford: Oxford University Press, 2000) at 191.
} 
constitution, such as the one by the Israel Democracy Institute, will likely lack the potential of being part of a reconciliation process and end up entrenching the status quo. ${ }^{85}$

The Declaration's presentation of the area of historic Palestine as terra nullius adds another layer of complication. Not only does the Declaration congeal the moment that most Palestinians see as a catastrophe, it also congeals the colonial reality and narrative of terra nullius. This colonial narrative, as will be discussed in the next chapters, finds its way into the constitutional regime and the laws of the state. Insisting on adopting the Declaration unaltered for any future change, or seeing the Declaration as providing the authorization (and hence the limits of any change) for the constitution, eliminates any potential for the decolonization of law through constitutional change.

\section{Summary and Conclusions}

An inquiry into the question of "who is the People in Israel?" based on social contract theories and basic norm theories does not provide a conclusive answer. While legal and political discourse often avoids dealing directly with who is included and excluded, the courts and the academic literature tend to assume that the People includes Jewish citizens only. The hostility to the idea of an Israeli nation, the refusal to recognize it, and seeing it as a threat to the Jewish nation and the Jewish definition of the state further supports this observation.

This observation is further supported by examining the Declaration of the Establishment of the State of Israel, which is the first and one of the most important constitutional texts. A textual and legal analysis of the Declaration shows that the people who

\footnotetext{
${ }^{85}$ In this context, Aeyal Gross observes that the "Constitutional Revolution" in Israel in the 1996 (see chapter VI for details) failed to address transitional justice issues, leading him to question whether indeed it was truly revolutionary. See Aeyal Gross, "The Constitution, Reconciliation, and Transitional Justice: Lessons from South Africa and Israel" (2004) 40 Stanford Journal of International Law 47.
} 
are presumed to have come together to declare the state were the Jewish people, or Jewish inhabitants of Palestine at the time. The land was presented as terra nullius and the Palestinians, who were almost half of the inhabitants, were absent. Their role was not as partners in the founding, but as individuals who were invited to join (under certain conditions) an already existing body with their rights emanating from that body rather than accorded to them inherently as individuals. Similarly, the Declaration as a legal text gives preference to Jewish nationalism over universal principles. This seems to be the conclusion flowing from the Yerdor and Neiman opinions and Barak's position that sees the Declaration as the "authorizing" document created by the People. It also plays a role in the constitutional system in that basic laws or a formal constitution cannot contradict the principles set out in it including the Jewish character of the state. This analysis points in the direction of the conclusion that the Declaration's People, both textually and legally, excludes the Palestinians in Israel. The Declaration does provide a conditional offer of future inclusion, but this offer and the inclusion are contingent on accepting the narrative in the Declaration, not creating a new narrative, or integrating additional narratives that would reflect the new "we". In this context, one wonders if the participation or lack thereof of the Palestinian citizens was seen to be of any importance. A close look at the Law and Administration Ordinance, which was the first act of legislation adopted by the state through the "Provisional Council of State", might be insightful. The Ordinance regulated the governance of the new state and the temporary organs which included the "Provisional Council of State" which was its legislative authority and the "Provisional Government", which was the executive authority. Regarding the composition of these two organs, the Ordinance provided that "[r]epresentatives of Arabs being resident of 
the State who recognise the State of Israel will be co-opted on" these two bodies. "Their nonparticipation" in these two bodies, however, "shall not derogate from its power."

It may be argued that the language of the Declaration with its exclusionary "we" and its narrative that vacates the land from the majority of its inhabitants should not attract much attention, that it is merely a statement made in an antiquarian language reflecting the zeitgeist of that era and the excitement of the founders of the nascent state as well as the influence of the horrors of the Holocaust and the war-like situation at the time. The text of the Declaration however is still playing an increasingly important role. In addition to the legal relevance as a tool of interpretation, it has gained more importance since the adoption of the basic laws. Its increasing importance can be seen in the various initiatives for adopting a formal constitution for Israel that adopt the Declaration in its entirety as the preamble or part of it. In this context, the strict adherence to the Declaration and the refusal to entertain other options or even open the text for changes entrenches the "we" and "them" dichotomy, maintains an exclusive conception of the People and congeals and celebrates a colonial narrative. It also constitutes a barrier to transformative constitutional change that could usher in equitable arrangements, an inclusive conception of the People and an opportunity to address past injustices.

This exclusion from the People at the foundational phase resonates throughout the constitutional edifice in its entirety. After the founding stage comes the stage of deciding who is part of the newly formed state. Citizenship and immigration laws carry out this function, which is essentially a process of engineering the People. This will be the focus of the next chapter: examining who is thought of as part of the People through the prism of the

\footnotetext{
${ }^{80}$ Sections1(a) and 2 (a) of the Law and Administration Ordinance-1948, Official Gazette, No. 2 (21 May 1948).
} 
citizenship and immigration laws. After the People is engineered and designed, it is expected to play a role in its self-governance. This is done through representation and political participation. The constitutional provisions and the laws governing political participation in Israel include special safeguards that are meant to demarcate the contours of what is permissible in electoral politics. These in essence also decide who is considered the People, for as we saw in chapter I, the People exercises its sovereignty through elections, among other ways. An examination of these laws and what we can learn from them about the People will be a central theme of chapter V. The People is also the one that creates the constitution and holds constituent power. As such, examining the evolution of the constitutional regime, and the theory and practice of constitutional amendment provides an opportunity to understand who is the People as the constituted form (the state and its insinuations) sees it. Chapter VI will deal with these aspects. 


\section{Chapter IV}

\section{Engineering the People: \\ Israel's Immigration and Citizenship Laws and Policies}

\section{Introduction: Immigration, Citizenship and the Numbers Game}

The idea of the People, as discussed in chapter I, is very central to the constitutional regime and democracy. The literature review in chapter II pointed out that one of the prevailing approaches to justifying the Jewish and democratic definition of Israel emphasizes a distinction between the People as the citizenry, who supposedly exercise sovereignty, and the Jewish nation that merely exercises the right to self-determination in the state. This position is put forward by Barak, Rubenstein and Yakobson, Gavison and others. But this position is called into question by a close examination of different facets of the constitutional edifice, which reveals a different understanding of "who is the People". In the previous chapter, we reviewed and discussed some foundational concepts and texts emerging from the founding phase of the constitutional regime which shed light on who the founders of the state considered the People to be at that time. This chapter will continue this line of interrogation and examine who is the People that the different immigration and citizenship laws and policies try to create and maintain.

Citizenship claims a central place in defining and regulating the relationship between the individual and the state. Citizenship in its formal legal sense is the juristic expression of the relationship between the state and the individual. It is also the means by which formal membership in a political community is defined and is a condition for full and meaningful 
participation in the polity. Citizenship, conceived of as the right to have rights, is, as Hannah Arendt reminds us, the most basic of human rights. ${ }^{1}$ Immigration laws and policies that control access to citizenship are therefore of significant importance from a constitutional point of view, as they control access to membership in the People which underpins the constitutional regime. Since sovereignty is vested in the people, defining the contours of the political community, or the People, means defining the sovereign. One of the ways of controlling the identity of the sovereign while maintaining formal rules of democratic process is to control the composition of the citizenry. Additionally, immigration laws and policies that are part of the constitutional regime act as the mirror reflection of the People. To put it in Michael Walzer's words, "we who are already members do the choosing, in accordance with our own understanding of what membership means in our community and of what sort of community we want to have."2

Citizenship, as a formal normative category, is open to social engineering. One way of maintaining control or hegemony, especially in the context of a divided society, is by engineering the polity to maintain an overwhelming majority of citizens who belong to a specific national, ethnic or religious group. "Citizens and noncitizens" Linda Bosniak remarks, "are not beings found in nature; they are made and unmade by way of law and politics". ${ }^{3}$ An examination of law and politics is therefore necessary to understand who are made citizens, why, in what way and to what end. This will be the focus of this chapter: Israel's immigration and citizenship laws and policies and their role in shaping the political community and its composition, image and identity, and, by extension, in determining the People that exercises

${ }^{1}$ Hannah Arendt, The Origins of Totalitarianism (Orlando, FL: Harcourt Brace and Company, 1951) at 296.

2 Michael Walzer, Spheres of Justice: A Defense of Pluralism and Equality (New York: Basic Books, 1983) at 32.

3 Linda Bosniak, "Persons and Citizens in Constitutional Thought" (2010) 8:1 International Journal of Constitutional Law 9 at 11. 
sovereignty. One theme that will run throughout this chapter is the ubiquitous and uneasy tension between the state's need to grant citizenship to all its inhabitants in order to legitimate its existence and escape the label of apartheid, and the state's need to fulfil its founders' conception of its raison d'etre being the establishment of a secure national home for the "ingathering of the [Jewish] exiles". The result is a number of laws and policies that offer a measure of partial inclusion through citizenship, but dilute this inclusion with an emphatic emphasis on and pursuit of the idea of creating, and then preserving, a Jewish majority. As the Supreme Court has stated on a number of occasions, a Jewish state must have, and maintain, a Jewish majority. ${ }^{4}$ Promoting a Jewish majority is therefore a normative precept. The other side of this formula recasts any Palestinian presence as the "Arab demographic threat". While the laws and policies oscillate between these two poles, the outcome of the operation of these laws and policies has tremendous impact on the idea of the People. This impact will be explored throughout this chapter.

This chapter will begin with a brief overview of the different ways Israel has dealt with the presence of the Palestinians in the areas under its control from the early days of the state. The different policies that were implemented then set the trend for the future, and guided the development of the citizenship legislation. The Law of Return-1950 and its relevance and impact will be discussed afterward. I will then examine the Citizenship Law-1952, the law that regulates the citizenship of the Palestinian citizens in Israel and the different amendments that were introduced over the years highlighting the impact on the Palestinian citizens and certain trends of exclusion. Naturalization through spousal sponsorship will be examined in depth in this

${ }^{4}$ EC 11280/02 Central Elections Committee for the Sixteenth Knesset $v$ Tibi (2003), IsrSC 57(4) 1 (in Hebrew) [Tib]; EA 2/88 Ben Shalom v. Central Elections Committee (1989), IsrSC 43(4) 221; HCJ 466/07 Galon v. The Attomey General (2012). 
section. I will then discuss demographic concerns in light of the definition of Israel as a Jewish and democratic state and its implications for equality. Throughout this chapter, I will examine the extent to which immigration and citizenship laws and policies in Israel affect the formation and composition of the People that exercises sovereignty and holds constituent power.

\section{The First Years (1948-1952)}

\subsection{Background}

During the time of the British Mandate (1922-1948), citizenship in Palestine was regulated by the Palestine Citizenship Orders. ${ }^{5}$ Immigration was regulated by the Immigration Ordinance and the related regulations. ${ }^{6}$ Throughout the Mandate, and as part of the policy of the Balfour Declaration and the Deed of the Mandate of 1922, many Jewish immigrants entered Palestine such that the percentage of Jews living in Palestine rose from about $10 \%$ in $1920^{7}$ to about $33 \%$ in $1946 .^{8}$ The promotion of Jewish immigration varied throughout that period and was affected by a number of factors which included the country's absorptive capacity, changes in British imperial policy, and resistance by the Palestinian Arabs to the Jewish national home policy. A major component of this policy was the facilitation of Jewish immigration. As a result of the Arab Revolt of 1936-1939, and the need to pacify the Palestinians and gain the support of the Arab World on the eve of World War II in 1939, the

5 Palestine Citizenship Order-1925; Palestine Citizenship Order-1942.

${ }^{6}$ Mutaz M. Qafisheh, The International Law Foundations of Palestinian Nationality: An Examination of Nationality in Palestine Under Britain's Rule (Leiden: Martinus Neijhoff, 2008).

${ }^{7}$ League of Nations, An Interim Report On The Civil Administration of Palestine during the period 1st July, 1920--30th June, 1921, (30 July 1921), online: <http://unispal.un.org/UNISPAL.NSF/0/349B02280A930813052565E90048ED1C>.

${ }^{8}$ United Nations Special Committee on Palestine, Report to the General Assembly, UNGAOR, (3 September 1947), $\sup \quad$ No 11, A/364, online: <http://unispal.un.org/UNISPAL.NSF/0/07175DE9FA2DE563852568D3006E10F3>. 
British authorities issued the 1939 White Paper which restricted Jewish immigration and land transactions.

After the creation of Israel in 1948, and in line with Zionist principles, the Declaration of Independence declared that the state "will be open for Jewish immigration and for the ingathering of the exiles". ${ }^{10}$ The first act of legislation by the Provisional Council of State included provisions reversing some of the Mandate-era legislation limiting the entry of Jews to the country. ${ }^{11}$ This allowed the entry of hundreds of thousands of immigrants many of whom were European Jews who were in Displaced Persons camps in Europe and in Cyprus. It is estimated that by 1951 , over 687,000 immigrants entered the country, doubling the Jewish population. $^{12}$

While the policy of almost unlimited Jewish immigration was the official position in theory and practice, an opposite policy, one that seeks to reduce the size of the population, applied to the Palestinians. The roots of this policy can be traced back to the era before the creation of Israel in 1948. Since the early years of the twentieth century, the leaders of the Zionist movement were preoccupied with what they called "the Arab Problem" or "the Arab Question". ${ }^{13}$ The problem for them was the existence of a large number of Arabs in Palestine, which would make the task of establishing a Jewish state -which would logically have a Jewish

9 UK, HC, "Palestine Statement of Policy", Cmd. 6019 (1 May 1939) available online http://unispal.un.org/UNISPAL.NSF/0/EB5B88C94ABA2AE585256D0B00555536

${ }^{10}$ Declaration of the Establishment of the State of Israel, appendix "A".

11 Section 13 of the Law and Administration Ordinance-1948, Official Gazette, No. 2 (21 May 1948).

12 Don Peretz \& Gideon Doron, The Government and Politics of Israel, 3d ed (Boulder, Co: Westview Press, 1997) at 48.

${ }^{13}$ The term "the Arab Question" emerged in the 1920s. It was used to describe the issue of how the Zionist movement should deal with the indigenous Palestinian population in Palestine. In a way, it is a reflection of how Europe saw the presence of Jews in its territory as the "Jewish Question." See, Shabtai Teveth, Ben Gurion and the Palestinian Arabs: From Peace to War (Oxford: Oxford University Press, 1985). 
majority- hard if not impossible. ${ }^{14}$ Ben-Gurion, for example, argued that the fact that more than $40 \%$ of the population in the area allocated to the Jewish state under the 1947 plan were Arab "questions our ability to maintain Jewish sovereignty... Only a state with at least 80 per cent Jews is a viable and stable state." ${ }^{\prime 15}$ A number of solutions for "the Arab question" were suggested, including population transfer. The transfer of the Arab population was a central theme in the thinking about the "Arab question". ${ }^{16}$ The idea can be traced back to the beginning of political Zionism in the late nineteenth century, ${ }^{17}$ though it was discussed and took a more concrete shape in the 1930s and 1940s especially after the Peel Committee suggested the idea of transfer as part of its partition proposal in its report from $1937 .{ }^{18}$ More specifically, the issue of citizenship for Palestinians in the Jewish state was discussed by the Jewish Agency Executive (the highest authority in the Yishuv and the precursor of the Israeli Government) in November 1947. The consensus was to give as many Palestinians in the Jewish state the citizenship of the Arab state, rather than that of the Jewish state, even though the Partition Plan left the choice to individuals. The motivation behind this approach was BenGurion's position that the Arabs were "a fifth column", and that not giving them citizenship

\footnotetext{
${ }^{14}$ See for example the statement by Menachem Ussishkin in the meeting of the executive Committee of the Jewish Agency in 1938: "We cannot start the Jewish state with ... half the population being Arab ... Such a state cannot survive even half an hour. It [i.e., transfer] is the most moral thing to do ... I am ready to come and defend ... it before the Almighty..." (as quoted in Benny Morris, The Birth of the Palestinian Refugee Problem Revisited, 2d ed (Cambridge: Cambridge University Press, 2004) at 50) [Morris, "The Birth Revisited"].

15 As quoted in Ilan Pappe, The Ethnic Cleansing of Palestine (London: One World, 2006) at 48 [Pappe, "The Ethnic Cleansing"'].

${ }^{16}$ Nur Masalha, The Expulsion of the Palestinians: The Concept of 'Transfer' in Zionist Political Thinking (Washington D.C.: Institute of Palestine Studies, 1992) at 1 [Masalha, "The Expulsion"].

17 Ibid at 5-8.

18 League of Nations, Report of the Palestine Royal Committee, (30 November 1937) online: <htep://unispal.un.org/UNISPAL.NSF/0/08E38A718201458B052565700072B358>.
} 
would make it easy to expel them in the event of war. ${ }^{19}$ It is with this mindset that the Israeli leadership approached the question of the status of the Palestinians.

On 29 November 1947, the United Nations General Assembly adopted the Partition Plan to solve the question of Palestine. Violence ensued and developed into a full-fledged war in April- May 1948. Between December 1947 and the end of the war in 1949, the overwhelming majority of the Palestinians living in the areas that fell under Israeli control fled or were expelled to neighbouring countries or other areas of Palestine. The number of the refugees ranged from 600,000 to 935,000 , depending on the source. ${ }^{20}$ This massive exodus reduced the number of Palestinians in Israeli-controlled areas by $80 \%-85 \%$. The reasons behind this large number of refugees have been a subject of debate for the past half-century. The official Israeli version is that the refugees left at the orders of Arab leaders, and that in any event this displacement was the result of the war where the very existence of the Jewish community was at stake. ${ }^{21}$ On the other hand, Palestinians argued that there was no evidence that such orders did exist and that the displacement was the result of what is now known as ethnic cleansing. ${ }^{22}$ In the last two decades a number of academic studies have been published that support the position that most of the refugees were either expelled directly by Israeli soldiers or fled for fear for their lives. In this context, views diverge on whether the expulsion

\footnotetext{
19 Benny Morris, The Birth of the Palestinian Refugee Problem, 1947-1949 (Cambridge: Cambridge University Press, 1987) at 28.

${ }^{20}$ Morris, "The Birth Revisited", supra note 14 at 602-603; Salman Abu Sitta, Atlas of Palestine (London : Palestine Land Society, 2004) at 86.

21 See e.g. "Israel, the Conflict and Peace: Answers to Frequently Asked Questions" (30 December 2009), online: Israel Ministry of Foreign Affairs <http://mfa.gov.il/MFA/ForeignPolicy/Peace/Guide/Pages/FAQ_Peace_process with Palestinians_Dec 200 9.aspx\#Refugees $1>$.

${ }^{22}$ Avi Shlaim, “The Debate About 1948” (1995) 27:3 International Journal of Middle East Studies 287.
} 
was the result of a previously devised plan, as Ilan Pappe and Nur Masalha argue, ${ }^{23}$ or was one of the unplanned outcomes of the war as Benny Morris argues. ${ }^{24}$

Whether it was pre-planned or not, the outcome was the reduction of the Palestinian population to a small minority. The leadership of the new state saw this demographic shift, which created a relatively homogenous Jewish state, as a major war gain, ${ }^{25}$ and approvingly described the exodus of the Palestinians as a great achievement and a miracle. ${ }^{26}$ In addition to the expulsions, the state took a number of measures in order to block attempts to return and in order to make return unattractive, such as destroying the villages from which the refugees fled. The law played an important role in the process of maintaining the outcome of the displacement and contributed to reducing the number of the Palestinians. The law was heavily influenced by the mindset, described above, of the Zionist leadership regarding the Palestinians. While this was the prevailing mindset in the leadership, there were some exceptions. Less influential groups such as the dovish party MAPAM had a more nuanced position that fluctuated from acquiescence to the leadership and ambivalent opposition. Its members played a role in tempering the policy on some occasions. ${ }^{27}$

\subsection{The Regulation of Citizenship and Residency $1948-1952$}

The 1948-1949 war that led to the creation of the state was, at least in the eyes of the law, a turning point. The Yishuv turned from an organized pre-state Jewish community into a state. This transformation was accompanied with another one; the change from the logic of

\footnotetext{
${ }^{23}$ Pappe, "The Ethnic Cleansing", supra note 15; Masalha, "The Expulsion", supra note 16; Masalha, $A$ Land Without a People: Israel, Transfer and the Palestinians 1949-96 (London: Faber and Faber, 1997) [Masalha, "A Land”]. 24 Morris, "The Birth Revisited", supra note 14 at 60.

${ }_{25}$ Benny Morris, Israel's Border Wars, 1949-1956: Arab Infiltration, Israeli Retaliation, and the Countdown to the Suez War (Oxford: Oxford University Press, 1993) at 153 [Morris, "Israel's Border Wars"].

26 Morris, "The Birth Revisited", supra note 14 at 348.

${ }_{27}$ See Morris, ibid at 169, 171, 241; Nur Masalha, Politics of Denial: Israel and the Palestinian Refugee Problem (London: Pluto Press, 2003) at 60.
} 
the Zionist revolution (understood as a rupture in the legal and political system) to the logic of statehood. As Raef Zreik observes, "a victorious revolution inevitably ceases to be a revolution, transforming itself into state institutions." 28 In this sense, the violence of the battlefield gives way to the violence of the law. ${ }^{29}$ This change can be best understood through Ben Gurion's emphasis on the idea of mamlacbtiyut which crudely translates into "statism". Yoav Peled explains that mamlachtiyut "conveys a sense of a common purpose, as determined by an all-encompassing social-political community and expressed in the rule of law." ${ }^{, 30}$ Law and its equal and non-arbitrary application were central to the idea of mamlacbtiyut. But this state, as Peled explains, was not neutral, and in essence its "statism" subsumed the pre-state values and principles. ${ }^{31}$ To put it in Zreik's words, "Israel was more revolution than state in the early decades." ${ }^{\prime 32}$ It was a system that needed the legitimating guise of the state characterized by the rule of law, where the relationship between the state and the individual is built on citizenship. At the same time, it was inherently tied to the idea of the ethnic revolution characterized by the Zionist project. The system oscillated between the two poles, and this oscillation is evident in the population policy and citizenship arrangements.

An interesting question in this context is, if a homogenous Jewish state was the goal, and the overwhelming majority of Palestinians were expelled in order to achieve this goal, why did this expulsion/flight stop at $85 \%$ and not $100 \%$ ? Why was a minority allowed to stay and given citizenship? While the need to comply with the logic of the state and benefit from the legitimating guise of a "universal" citizenship played a role, there were other external reasons

${ }^{28}$ Raef Zreik, "Why the Jewish State Now?" (2011) 40:3 Journal of Palestine Studies 23 at 30.

${ }^{29}$ Robert Cover, "Violence and the Word" (1985-1986) 95 Yale Law Journal 1601.

30 Yoav Peled, "Ethnic Democracy and the Legal Construction of Citizenship: Arab Citizens of the Jewish State" (1992) 86:2 American Political Science Association 432 at 440-441.

31 Ibid at 434-435.

${ }^{32}$ Zreik, supra note 28 at 26. 
that were probably seen as weightier. One reason was the fact that the Palestinians were a minority of $12.5 \%$ of the population. This is a dramatic decrease in numbers, especially when compared to the pre-war period when Palestinians out numbered Jews 2 to 1 , or even the $45 \%$ envisaged by the Partition Plan. The leaders of the new state saw that this number was insignificant. ${ }^{33}$ It was a cheap price to pay for a greater sense of legitimacy especially since according to the 1947 Partition Plan, the two new states were supposed to provide citizenship to their inhabitants unless they opted for the citizenship of the other state. Diplomacy and international standing also contributed to this decision. Arab states accused Israel of mistreating the Palestinian minority, and raised the issue at the UN. This was at a time when Israel's international standing was fragile, especially since it was refused admission to the UN in December of $1948 .{ }^{34}$ In its second application in May 1949, Israel's UN envoy highlighted that his country "had conducted the only democratic election with full popular participation" in the region and that "it had established a legislature based on popular suffrage". ${ }^{35}$ He further emphasized that the Government was committed to protecting minorities without interference or discrimination. ${ }^{36}$ Another reason was fear of irredentism. Treating the Palestinians, or some of them, as citizens would prevent the development of the question of their selfdetermination. ${ }^{37}$ The fact that $60 \%$ of the Palestinians who voted in the 1949 election voted

${ }^{33}$ Ian Lusitck, Arabs in the Jewish State: Israel's Control of a National Minority (Austin: University of Texas Press, $1980)$ at 53.

${ }^{34}$ Ibid at 61.

35UNGAOR, 1949, 44 th meeting, UN doc A/AC.24/SR.45, online: <http://unispal.un.org/unispal.nsf/9a798adbf322aff38525617b006d88d7/1db943e43c280a26052565fa004d8174 ?OpenDocument>.

36 Ibid.

${ }^{37}$ Lustick, supra note 33 at 62. 
for the ruling party also indicated that this minority could potentially be a reservoir of votes for MAPAI, which it was until the election of $1965 .^{38}$

While these were the main reasons the Palestinian minority was permitted to stay, still its members were not given citizenship until later. The content of citizenship as a legal category was in a state of indeterminacy from 1948 until the enactment of the Citizenship Law1952. While the Mandate-era Palestine Citizenship Order was still valid by virtue of section 11 of the Israeli Law and Administration Ordinance-1948, two conflicting court decisions on the issue of the status of the Palestine citizenship were issued. ${ }^{39}$ This state of indeterminacy came to an end with the enactment of the Citizenship Law. Section 18 (a) of the Law retroactively repealed the Palestine Citizenship Order and provided the grounds for citizenship which applied retroactively. The situation was further clarified by the Supreme Court when it ruled that Palestinian citizenship ceased to exist with the end of the Mandate, and that Israeli citizenship did not exist until it was created in $1952 .{ }^{40}$ One implication of this ruling was that between 1948 and 1952 all the inhabitants of Israel were stateless.

Even though all inhabitants of Israel were formally stateless in the early years of the state, events characterized by the oscillation between statehood/citizenship and ethnic revolution/exclusion took place without formal citizenship legislation. Two parliamentary

38 Peled, supra note 30 at 436.

${ }^{39} \mathrm{~A}$ number of decisions by Israeli courts provided conflicting positions on the question of citizenship before the 1952 law. In one case for example, a judge of the Tel-Aviv District Court relied on public international law and ruled that "every individual who, on the day of the establishment of the State of Israel, was resident in the territory which today constitutes the State of Israel, is a also a national of Israel. Any other view must lead to the absurd result of a state without nationals..." CA 876/50 A.B. v. M.B. 3 PM 263 at 271-272. On the other hand, the same Court (Tel-Aviv District Court) decided in 1953 -discussing the state of citizenship before the enactment of the Citizenship Law- that with the end of the Mandate, Palestine citizenship ceased to exist. Citizenship, the Court ruled, "creates a bond of loyalty between the state and the national" and while this bond disappeared with the end of the Mandate, a new bond of loyalty with the state of Israel "cannot automatically devolve." Oseri v. Oseri PM 8 76, as quoted in M.D. Gouldman, Israel Nationality Law Jerusalem: Institute for Legislative Research and Comparative Law, 1970) at 16.

40 HCJ 174/52 Hussein, acting for Mobammad Ali Abu Dabood v. The Commander of Acre Prison (1952), IsrSC 6897 at 901 (in Hebrew). 
elections took place (1949 and 1951), one municipal election in which the Palestinian minority participated, ${ }^{41}$ and hundreds of thousands of new immigrants entered the state. On the other hand, the state continued to expel Palestinians. ${ }^{42}$ This was done without formal citizenship legislation, but it was facilitated by conducting a census, and the enactment of a number of laws which were meant to count and register the population. These were mainly motivated by the Government's wish to maintain the main war gain, i.e. the demographic shift. During the war, even before the Israeli army had gained control over many parts of the country, the authorities were debating the best way to block the trickle of refugees attempting to return in order to "freeze" the demographic picture then. ${ }^{43}$ One of the ways to do so was to count and verify the identity of those who did not leave to make it easier to distinguish between returning refugees, who were designated as "illegal", and Palestinians who did not leave, who were deemed "lawful". This was an attempt to create, or at least to lay the foundations of a "universal" citizenship based on habitual residence in a territory, but since it was the result of the oscillation between the two poles of state/citizenship and revolution/exclusion, this "universal" foundation intended, in essence, to exclude the majority of those who lived in the territory prior to the war. ${ }^{44}$

The census, therefore, played an important role in who was "legal" and who was "illegal", which would later play a role in the grant of citizenship. As in other colonial situations, the census also played a role in the creation and maintenance of different

\footnotetext{
41 The next chapter will include a discussion on this participation and its circumstances.

${ }^{42} \mathrm{See}$ for example the town of Majdal. The inhabitants who stayed after the war was over were transferred to the Gaza Strip in June 1950. See Morris, "The Birth Revisited", supra note 14 at 529.

43 Anat Leibler \& Daniel Breslau, "The Uncounted: Citizenship and Exclusion in the Israeli Census of 1948" (2005) 28:5 Ethnic and Racial Studies 880, at 891; Shira Nomi Robinson, Occupied Citizens in a Liberal State: Palestinians Under Military Rule and the Colonial Formation of Israeli Society, 1948-1966 (PhD Dissertation, Stanford University, 2005) at 49-52 [unpublished].

${ }^{44}$ Leibler \& Breslau, supra note 43 at 892.
} 
population categories, the effective surveillance of the population (mainly Palestinians), and facilitated devising methods for their control. ${ }^{45}$ The census took place on 8 November 1948 , at the time when the war was still on, and at a time when Israeli forces were still acquiring more territory. As a result, the census was only able to account for 69,000 Palestinians and excluded most of the Bedouin communities, prisoners in POW camps and residents of the Upper Galilee which had fallen under Israeli control only in late October. ${ }^{46}$ There was another census for some of those areas in 1949 which was carried out for the same purpose, that is, to "freeze" the demographic picture.

The registration of the inhabitants was done according to Emergency Regulations (Registration of Inbabitants), 1948, and after February 1949, according to the Inhabitants Registration Ordinance-1949. Residency, in the sense established by this Ordinance, functioned as citizenship, and allowed the "legal" residents to stay in the country. It also determined eligibility to vote. The officials of the Interior Ministry interpreted the provisions of the Ordinance narrowly to exclude as many Palestinians as possible. For example, they interpreted "person located in the country" to be a person who is legally present in country, which excluded a large number of returnees because they were deemed to have entered the country illegally. ${ }^{47}$ Many of the "illegal" residents were expelled after large "sweeping" campaigns by the Israeli authorities whose goal was "to reduce the size of the population while preserving

45 Anat E. Leibler, "You Must Know Your Stock': Census as Surveillance Practice in 1948 and 1967" in Elia Zureik, David Lyon \& Yasmeen Abu-Laban, eds, Surveillance and Control in Israel/Palestine (London: Routledge, 2011) 247. For the role of the census in other colonial situations, see Benedict Anderson, Imagined Communities: Reflections on the Origins and Spread of Nationalism, revised ed (London: Verso, 2006) at 164-170.

${ }^{46}$ Robinson, supra note 43 at 52.

47 Ibid at 85. 
the laws of the state." ${ }^{48}$ On many occasions even those who were registered were expelled. ${ }^{49}$ The expulsions were tempered somewhat by petitions to the Supreme Court. The Court's approach, however, was not consistent and relied mainly on technicalities. ${ }^{50}$ In a number of cases, even those petitioners whom the Court had found in favour of were expelled despite the Court orders, or new expulsion orders were issued against them. ${ }^{51}$ The expulsion was facilitated further by the introduction of the Probibition of Infiltration Ordinance-1954. ${ }^{52}$

Most of these enactments and policies were not intended to address the question of citizenship. The formal regulation of the question of citizenship and immigration had to wait until the enactment of the Law of Return-1950 and the Citizenship Law-1952, which will be discussed in the next two sections.

\section{The Law of Return: Jews-only Immigration Policy}

The Law of Return-1950 is Israel's main immigration law, and together with the Citizenship Law-1952 regulates access to citizenship. The overwhelming majority of those who have acquired Israeli citizenship acquired it through this law. The Supreme Court, politicians and many academics see it as one of the most important manifestations of the Jewish definition of the state. As the main immigration legislation that determines citizenship, it also, by extension, determines entry to and membership in the People, hence its importance to the inquiry into

\footnotetext{
${ }^{48}$ Minutes of Military Government Meeting in the Headquarters in Jaffa, Attended by Governors and the Advisor to the Prime Minister on Arab Affairs, Yoshua Palmon (27 September 1951), Tel-Aviv, Israel Defence Forces Archives (IDFA 834/53-133), cited in and translated by Robinson, supra note 43 at 63.

${ }^{49}$ Robinson, supra note 43 at 73.

50 Menachem Hofnung, Israel-Security Needs vs. The Rule of Law (in Hebrew) Jerusalem: Nevo Publishing, 1991) at 144.

51 Ibid at 145.

52 It should be mentioned that in addition to expulsion, the policy was to deter returning refugees by use of fatal force. Morris observes that by 1956 2700-5000 refugees were killed trying to return. Morris, "Israel's Border Wars", supra note 25 at 125-133, 145-147.
} 
who the People is. As Azmi Bishara and Hassan Jabareen note, since the Law of Return is the most important immigration legislation, and since it is limited to Jews and their family members only, the most important question in Israeli immigration and citizenship law became "who is a Jew?" rather than "who is a citizen?". ${ }^{33}$ In a sense, these two questions correspond to an ethnic/religious definition of the nation and the People respectively, and the fact that the main question is "who is a Jew?" points to an attempt to assert the dominance of the ethnic nation over the future image of the People. In this section, I will examine the importance of the law and its relation to the constitutional regime highlighting its impact on shaping the People. I will also examine how different approaches to the Jewish definition justify the law within their understanding of the Jewish and democratic definition.

\subsection{The Law of Return as a Foundational Element of the Jewish State}

The Law of Return-1950, whose main section provides that " $[E]$ very Jew has the right to ascend [immigrate] to the Country" is seen as one of main expressions of the Jewishness of the state, in addition to being its main immigration law. The Supreme Court has emphasized the importance and significance of the law many times. ${ }^{54}$ The law is seen as

one of the most important laws in Israel, if not the most important. Although it is not a "basic law" in form, it is certainly a basic law in essence... it is the most fundamental of all laws, and it constitutes, in the words of David Ben-Gurion, the "foundation law of the State of Israel." This is the key to entering the State of Israel, which constitutes a central reflection of the fact that Israel is not merely a democratic state, but also a Jewish state; it constitutes "the constitutional cornerstone of the character of the State of Israel as the state of the Jewish people"... it gives expression to the "justification... for the existence of the Jewish state"... it is an expression of the right of the Jewish people to self-determination..$^{55}$

\footnotetext{
53 Azmi Bishara, From the Jewish State to Sharon: A study in the Contradictions of the Israeli Democracy (in Arabic), (Ramallah: MUWATIN- The Palestinian Institute for the Study of Democracy, 2005) at 39; Hassan Jabareen, "The Constitutional Conception of the 'Jewish and Democratic' State" in Honaida Ghanim \& Antwane Shalhat, eds, The Meaning of a Jewish State (in Arabic) (Ramallah: MADAR The Palestinian Forum for Israeli Studies, 2011) 33 at $39,51$.

${ }^{54}$ See e.g. HCJ 3648/97 Stamka v. The Minister of Interior (1999), IsrSC 53(2) 728 [Stamka]; HCJ 2597/99 Toshbeim v. Minister of Interior (2005), IsrSC 59(3) 721 [Toshbeim].

55 Tosbbeim, ibid at 733 [translated by author].
} 
The nationalist aspect of the Law of Return is consistently emphasized. The Court and many commentators see it as the main legal expression of Zionism. ${ }^{56}$ Former Chief Justice Barak, for example, asserted that it "is a national law that came to fulfill the central purpose of the State of Israel, the purpose of gathering the exiles of Israel [Jewish people]." Rubenstein stressed that in the five words of section 1 of the law, the legislator has internalized "all of the theory of Zionism in its entirety while standing on one leg." ${ }^{58}$ Justice Rubenstein relates the right to a divine promise, which "exists and is embedded in the Jewish genetic code since the beginning of the world." J9 Justice Chechin emphasized the uniqueness of the "right" to return explaining that

[T] his decisiveness of the right derives from its unique nature, in that it is the concrete expression of the connection between the Jew - as such - and the land of Israel. A Jew from the Diaspora who wishes to settle in Israel is no immigrant; he is "ascending" to Israel, he is "coming back" to Israel, in the sense of "And the children shall return to their borders" Jeremiah 31, 16 [41]). .00

Though the Law mainly regulates the right of Jews to immigrate, it is not seen as an immigration law, or at least, not as an immigration law only. Justice Barak for example approvingly quoted David Ben Gurion during the debates on the Law in the Knesset when he stated that it "has nothing to do with immigration laws. It is the eternal law of Jewish history. This law establishes the national principle that led to the founding of the State of Israel." ${ }^{, 61}$ In the rest of the paragraph - the part that Barak did not quote- Ben Gurion went as far as saying that "this law determines that it is not the state that determines the right of diaspora Jews to

\footnotetext{
56 Ayelet Shachar, "Whose Republic? Citizenship and Membership in the Israeli Polity" (1999) 12 Georgetown Immigration Law Journal 233 at 235.

${ }^{57}$ HCJ 265/87 Brasford v. Ministry of Interior (1989), IsrSC 43(4) 793 at 845.

${ }^{58} \mathrm{HCJ} 10226 / 08$ Zvidovsky v. Minister of Interior (2010) at para. 3.

${ }^{59}$ Ibid at para. 4.

60 Stamka, supra note 54 at 757.

${ }^{61}$ Divrei Ha Knesset vol. 6 (1950) at 2036, cited in Toshbeim, supra note 54 at 733 [translated by author].
} 
settle in it, but the right of a Jew to settle is inscribed in him as a Jew in case he decides to join settling the country." ${ }^{, 62}$ Further support for the national principle can be found in the Declaration of Independence and in the World Zionist Organization and Jewish Agency Status Law 1952, which provides in section 1 that the state's "gates are open... to very Jew wishing to immigrate to it." old vision of the return to its homeland". ${ }^{64}$

The nature and scope of the right to immigrate to Israel comes as a natural extension of this reasoning. The right is given to anyone who is Jewish, his/her children, grandchildren and their spouses. The right is almost absolute; there are only a few exceptions relating to public health and safety. ${ }^{65}$ The almost absolute nature of the right found expression in the words of Justice Chechin when he stated that

The main characteristic of the right is it decisiveness, a right which is almost absolute. Every Jew, as such, can, has the right to - upon his will only- to exercise his right to return, the right of "And the children shall return to their borders". Apart from those exceptions -which are limited in scope- the right cannot be made conditional and the authority does not have the discretion to gtant, or not to grant, a right of return to a Jew who wishes to ascend to Israel.66

The Law of Return, in combination with section 2 of the Citizenship Law, gives almost automatic citizenship to anyone who is eligible. It presents a unique and swift channel of

62 Ibid.

${ }^{63}$ Section 1 provides: "The State of Israel regards itself as the creation of the entire Jewish people, and its gates are open, in accordance with its laws, to every Jew wishing to immigrate to it" [translated by author].

${ }^{64}$ Section 2 provides that: "The World Zionist Organisation, from its foundation five decades ago, headed the movement and efforts of the Jewish people to realise the age-old vision of the return to its homeland and, with the assistance of other Jewish circles and bodies, carried the main responsibility for establishing the State of Israel" [translated by author].

${ }^{65}$ The exceptions are set out in section 2(c) which provides that

An oleh's [ascendant, or Jewish returning immigrant] visa shall be granted to every Jew who has expressed his desire to settle in Israel, unless the Minister of Interior is satisfied that the applicant

(1) acts against the Jewish people; or

(2) is likely to endanger public health or the security of the State.

(3) is a person with a criminal past that is likely to endanger public safety.

Translation available online, "Law of Return 5710-1950", online: Ministry of Foreign Affairs <http://www.mfa.gov.il/mfa/mfa-archive/1950-1959/pages/law\%20of\%20return\%205710-1950.aspx >.

${ }^{66}$ Stamka, supra note 54 at 757 [translated by author]. 
gaining citizenship which is distinguishable from naturalization, or citizenship first granted to the Palestinian minority. It further distinguishes the Jewish citizens from other citizens in that it sees all Jews as one unit subject to one rule whatever their place of origin. Thus, Jews who were Palestinian citizens prior to 1948 were deemed as "olim" (ascenders- returning Jews) according to section 4 of the law. ${ }^{67}$ This provision reflects the desire to eliminate any distinction between Jews who were born abroad and those born in Mandate Palestine/Israel. ${ }^{68}$ Until 1980, all Jewish citizens were deemed to have "returned" even if they were born in Israel, and they were registered in the Population Registry as "citizens by return". After the 1980 amendment, those who are born to Israeli Jewish citizens acquired citizenship by birth. But still, despite the fact that section 4 of the Law of Return no longer has any practical relevance (although it is formally valid), it seems that it still has significance on the political and symbolic level. Barak for example cited section 4 to emphasize "the inclusive nature and broad conception of the Law of Return" and that "aliya' is not a technical term. It is a social, valueladen, and national term. ${ }^{\prime 69}$ Interestingly, while legal fictions were used to demonstrate the unity and the rights of Jews only, no similar provision was introduced to highlight unity among Israeli citizens.

\footnotetext{
67 Section 4 of the Law of Return provide that: "Every Jew who has immigrated into this country before the coming into force of this Law, and every Jew who was born in this country, whether before or after the coming into force of this Law, shall be deemed to be a person who has come to this country as an oleh under this Law." ${ }^{68}$ Amnon Rubenstein, "Israel Nationality" (1967) 2 Tel Aviv University Studies in Law 159 at 161[Rubenstein, "Israeli Nationality].

${ }^{69} \mathrm{HCJ}$ 2597/99 Tosbbeim v. Minister of Interior (2004) at para. 23 [translated by author]. Barak then adds, "[M]y children, and all tsabars [Israel born Jews] are seen as if they ascended to Israel. Their Israeli citizenship came to them -that's what the Citizenship Law explicitly states- "by way of return" (Section 2(b))." [translated by author]. He did not explain if this statement and other statements about Section 4 are symbolic in nature or if this is the valid law today.
} 
Given this almost absolute right that is given to Jews to immigrate to Israel and acquire automatic citizenship, and since the Law of Return is the main immigration law, the cardinal question of immigration law in Israel became "who is a Jew?".

\section{2. "Who is a Jew?" as a Constitutional Question}

In the discussion in chapter II, we saw that the idea of the People represents the "we" that underpins the constitutional order. Consequently, an exploration of the question of the People also means an exploration of the question of "we". The question of membership in the "we", or citizenship, is a constitutional question, for it decides the boundaries of the People and decides who can enter. This highlights the constitutional dimension of citizenship and immigration policies. Essentially, many of the debates on immigration and citizenship are debates on who is included in the People. In the years 1948-2011, more than three million people immigrated to Israel under the Law of Return, with the rate of immigration reaching as high as 199,516 in $1990 .^{70}$ Approximately $61 \%$ of all citizens classified as "Jews and others" (others being non-Jewish family members eligible for immigration under the law) are reported to have a place of origin other than Israel. About $30 \%$ of "Jews and others" were foreign born in 2011 . This figure was $64 \%$ in $1948 .^{71}$ Since the overwhelming majority of migrants entered Israel under the Law of Return, and the majority of the population is essentially the offspring of migrants under this law, it is the main immigration law in Israel. The main question that determines eligibility under this law is being Jewish or a family member of a Jew. The main question for Israeli immigration law, therefore, is not "who is a citizen?", but "who is a Jew?".

70 Statistical Abstract of Israel 2012 Jerusalem: Central Bureau of Statistics, 2012) at 232, online: <http://www.cbs.gov.il/shnaton63/st04 02.pdf >. The population of Israel in 2013 was eight million.

71 Statistical Abstract of Israel 2012 Jerusalem: Central Bureau of Statistics, 2012) at 160, online: <http://www.cbs.gov.il/shnaton63/st02_25.pdf $>$. 
This pivotal question has troubled the Israeli legal system since the $1960 \mathrm{~s}$. When the Law of Return was first enacted in 1950, it did not include a definition of who is a Jew despite the demands of religious members of the Knesset. ${ }^{72}$ In 1958, after consulting over 50 Jewish intellectuals worldwide, the Government decided to adopt a religious definition. ${ }^{73}$ This definition was challenged multiple times prompting the Knesset to introduce a statutory definition. ${ }^{74}$ The Knesset amended the Law of Return in 1970 and added section 4B which defined a Jew as "anyone who was born to a Jewish mother, or has converted to Judaism, and is not a member of any other religion", which matches the religious definition. This definition, however, was still ambiguous. There was (and still is) disagreement on what kind of conversion is valid, that is, according to which religious denomination (Orthodox, Conservative of Reform). The Orthodox stream applies very strict rules when it comes to most questions including conversion, while the other streams are more flexible. There is also disagreement on the meaning of the phrase "is not a member of any other religion." The Supreme Court decided that in order to qualify as Jew under the Law of Return, converts converted to Judaism abroad could meet the definition if the conversion was done in "a recognized Jewish community" even if it was not Orthodox. For conversions conducted in Israel, only Orthodox conversion is recognized. However, those who start their conversion process in Israel according to a non-Orthodox stream but finish the process abroad can qualify as Jews under the Law of Return. ${ }^{75}$ For the question of the interpretation of "is not a member of any other

\footnotetext{
72 Zerach Warhaftig, $A$ Constitution For Israel: Religion and the State (in Hebrew) Oerusalem: Mesilot PublicationsThe International Centre of the Mizrhai- The Mizrahi Worker, 1988) at 153-154.

${ }^{73}$ Michael Corinaldi, The Enigma of Jewish Identity: The Law of Return in Theory and Practice (in Hebrew) (Srigim Leon, Israel: Nevo Publishing, 2001) at 15.

${ }^{74}$ See e.g. HCJ 72/62 Raufeisen v. Minister of Interior (1962), IsrSC 132430 [Raufeisen]; HCJ 58/68 Schalit v. Minister of Interior (1970), IsrSC 23 (2) 477.

${ }^{75}$ Tosbbeim, supra note 54 .
} 
religion", two competing approaches, one religious- objective and the other cultural-national (or secular-liberal according to Rubenstein and Medina) were discussed in Brasford, with the latter chosen as the legal test. ${ }^{76}$ In recent rulings, the Supreme Court, however, has departed from that test and moved towards a religious test. ${ }^{77}$

Despite the emphasis on a national-cultural approach, the determination of these questions was made primarily according to religious rules. Even the "secular- liberal" test deals with religious issues. It comes as no surprise therefore that those decisions rely heavily on religious Jewish law with lengthy quotes from Jewish religious texts. Similarly, many of the questions that the courts deal with for the purpose of determining eligibility are about religious conduct - such as whether the petitioner was baptized or not, ${ }^{78}$ whether he/she visits church or not, ${ }^{79}$ whether he/she was married in a church or not, ${ }^{80}$ whether he/she wears a cross or not, ${ }^{81}$ or whether he/she was immersed in the ritual bath (tevila). ${ }^{82}$ The reality is that despite the attempt to present the definition and the tests as secular-liberal, they remain religious in their essence. In this context, it is useful to recall Azmi Bishara's observation that Zionism "has never been successful in providing a secular definition to Judaism that is different that the balchatic (religious law) definition, that is, belonging to the religion. The Jew nationally, for Zionism, is the Jew religiously."

One of the striking features of this definition and the way it has been interpreted is the emphasis on the religious dimension. Membership in the People, it turns out, has a lot to do

${ }^{76}$ Brasford, supra note 57. See also Amnon Rubenstein \& Barak Medina, Constitutional Law of the State of Israel (in Hebrw), $6^{\text {th }}$ ed vol 2 (Jerusalem: Schocken Publishing House, 2005) at 1079-1080.

77 Zvidovsky, supra note 58.

78 HCJ 563/77 Dorflinger v. Minister of Interior (1979), IsrSc 33(2) 97.

79 Brasford, supra note 57.

80 Zvidousky, supra note 58.

81 Raufeisen, supra note 74.

82 Zvidovsky, supra note 58.

${ }^{83}$ Bishara, supra note 53 at 31 [translated by author]. 
with religion. More striking is that it gives ample authority to individuals or bodies outside the state to make important decisions on who can immigrate, decisions that, as the Supreme Court has acknowledged, are inherently related to sovereignty. The determination of whether an individual is Jewish is usually done using documentation provided by the head of the Jewish community where the potential immigrant lives, or the by the Rabbi of that community. Essentially, it is a delegation of power to that person who confirms the Jewish identity of the future immigrant. It is even more so when conversion outside Israel is involved. The most significant part of the decision who to admit to Israel as an immigrant and a citizen (and by extension who can join the People) is in the hands of a foreign individual/body. Although this was a source of discomfort for some of the minority judges dealing with questions related to conversion, the majority were satisfied that supervision and control within those religious communities is enough to satisfy the integrity of the processes. ${ }^{84}$

The question of who is a Jew has an impact on many levels, not just on immigration, though immigration may be the most important. It affects the laws governing family law and inheritance, burial processes and, in some cases, the ability to purchase land or live in certain areas. In those situations also this question affects the conception of the People. For example, in an amendment to the Israel Land Law-1960 that dealt with land ownership of foreigners, among other issues, section $2 \mathrm{~A}(\mathrm{a})$ defined "foreigner" as any individual who is not a citizen or resident of Israel, or eligible to immigrate according the Law of Return. This section essentially makes all Jews akin to citizens or residents, or at least treats them as non-foreigners.

${ }^{84}$ See the dissenting opinion of Justice Tal in HCJ1031/93 Pesro (Goldstein) v. Minister of Interior (1995) IsrSC 49(4) 661 at 718 [Pesro]; see also the dissenting opinions of Justice Grunis, Procaccia, and Levi in Toshbeim, supra note 54. 
Given the anomalies that the Law of Return creates, it has been the subject of intense debates featuring a passionate range of criticisms and justifications. An exploration of these debates will help clarify the impact of the Law of Return on the idea of the People.

\subsection{The Law of Return and the People}

The Law of Return and the idea of automatic citizenship have always been controversial and have always been challenged as discriminatory, especially since Palestinian refugees are not allowed to return. Many Zionist theorists have therefore sought to provide justifications for the current law, or at least for the discriminatory conception of "return" underlying it. Given the inherent connection between the Law and Israel's definition as a Jewish state, most of the justificatory arguments follow the same lines as those, canvassed in chapter II, that seek to reconcile the Jewish with the democratic element of the definition of the state. These debates are broad and diverse; this section therefore will focus on those aspects of the debates that relate directly to the shaping of the idea of the People. ${ }^{85}$

One of the justifications for the Law of Return is pure math: in order to maintain a Jewish state, a Jewish majority is needed. A decrease in this majority, Ruth Gavison argues, will lead to instability and in the legislature, it will be harder to garner a majority to maintain the

\footnotetext{
85 The justifications of the law could be grouped in four main categories: (1) the national self-determination argument; (2) the "affirmative action" argument; (3) the international human rights law argument; and (4) the comparative argument. For a good summary of the arguments for an against the law, see Ruth Gavison, The Law of Return at Sixty Years: History, Ideology, Justification Jerusalem: Metzilah Center for Zionist, Jewish, Liberal and Humanist Thought, 2010) online: $<$ http://www.metzilah.org.il/webfiles/fck/file/shvut\%20eng\%20Book\%20Final.pdf >; Amnon Rubenstein \& Alexander Yakobson, Israel and Family of Nations (New York: Routledge, 2009). For counter arguments, see Raef Zreik, "Notes on the Value of Theory: Readings in the Law of Return- A Polemic", online: (2008) 2:1 Law and Ethics of Human Rights 13 [Zreik, "Notes"]; Nimer Sultany, Book Review of Israel and the Family of Nations: The Jewish Nation-State and Human Rigbts, by Alexander Yakobson and Amnon Rubenstein, (2008-2009) 15 Palestine Yearbook of International Law 439. Chaim Gans takes a more nuanced approach that does not support the existing arrangements and does not support a sweeping and unlimited policy that favors Jews, but he nonetheless supports some formulation of the idea of "return". See Chaim Gans, A Just Zionism (Oxford: Oxford University Press, 2008) at 121-122 [Gans, "A Just Zionism”].
} 
character of the state. ${ }^{86}$ This consideration is evident in the broad scope of the right and the economic incentives provided to immigrants through the policies of successive Israeli governments. ${ }^{87}$ Some of these aspects will be explored at length in the discussion on demography in section 5 below. For now, we will just note that the Law of Return is, and has been since its introduction, one of the main tools of shaping the composition of the People.

While this is the main functional aspect of the Law of Return, its impact goes beyond it and affects one of the most important aspects of the constitutional regime, for it is related to the constitutional definition and the idea underpinning the state, that is, Jewish selfdetermination. One of the main justifications of the law is based on the argument that Israel, as the nation-state of the Jewish people, that is, where they exercise self-determination, is justified in favouring Jews. This argument is accepted by the nationalists, the pragmatists and the liberal nationalists. It is based on the notion that the law should allow the state to maintain a strong Jewish majority, and should grant those who want to live in a majority Jewish society the opportunity to do so. ${ }^{88}$

${ }^{86}$ Ruth Gavison, Conditions for the Prosperity of the State of Israel: Without a Vision, the People Will Pay the Price: A Mega Purpose for Israel and its Implications (in Hebrew) (Haifa: The Samuel Neaman Institute for Advanced Studies in Science and Technology, 2006) at 59 online: <http://www.neaman.org.il/Neaman2011/userdata/SendFile.asp?DBID=1\&LNGID=2\&GID=2136> [Gavison, "Conditions for Prosperity"]; Ruth Gavison, "The Jewish State: The Principle Justification and the Desirable Character" (in Hebrew) (2002) 13 Tkhelet 50 at 63 [Gavison, "The Jewish State"].

${ }^{87}$ In 2013, in addition to the airfare, a single immigrant who is eligible according to the Lav of Return was eligible to a cash payment of NIS 18,069 (USD\$5,115). A couple is eligible for NIS 34,446 (USD\$9,752). This is in addition to a range of other benefits in housing, education, social services and other services and benefits. See Table of Assistance Amounts of Absorption Basket, online: Ministry of Immigration Absorption <http://www.moia.gov.il/English/Subjects/FinancialAssistance/Pages/TableAmountsBasket.aspx >.

88 Amnon Rubenstein \& Liav Orgad, "Human Rights, State Security and Jewish Majority: The Case of Immigration for the Purpose of Marriage" (in Hebrew) (2006) 48 HaPraklit 315 at 342-343; Gavison, "The Jewish State", supra note 86 at 75; Ruth Gavison, "Thoughts about the Significance and Implications of 'Jewish' in the Expression 'A Jewish and Democratic State"' in Aviezer Ravitzky \& Ydidia Z. Stern, eds, The Jewishness of Israel (in Hebrew) (Jerusalem: Israel Democracy Institute, 2007) 107 at 136-137 [Gavison, “Thoughts"]. Na'ama Carmi, The Law of Return: Immigration Rights and Their Limits (in Hebrew) (Tel-Aviv: Tel-Aviv University Press, 2003); Gans, supra note 85 at $121-122$. 
Critics of this argument highlight its discriminatory nature given that selfdetermination in Israel is limited to Jews only- the right to any form of self-determination for Palestinians in Israel is not recognized. Linking immigration to ethno-national selfdetermination, contrary to the arguments that it does not entail any discrimination against citizens because it applies to non-citizens only, does in reality have a discriminatory effect. The law openly favours one national group in a state that has two national groups. ${ }^{89}$ Law and policy that considers only the interests of one group and totally disregards the interests of a significant minority, as Dworkin argues, does not provide equal respect and concern to all citizens. ${ }^{90}$ This form of discrimination becomes even more acute because of the significant financial incentives offered to immigrants under the Law of Return, and other resources allocated almost solely to support the immigration of one group. ${ }^{91}$ It also prevents new members from joining the Palestinian community, which impairs the ability of the society to develop at the same rate as the Jewish society. The personal autonomy of the individual will be affected. ${ }^{92}$ Similarly, as will be explained in section 4.3 .3 . below, the law does discriminate in cases where Palestinians give up Israeli citizenship and try to regain it.

How does all of this affect the idea of the People? First, this argument risks creating two classes of citizenship based on national belonging. Proponents of the Law of Return insist that it does not discriminate against citizens in the state, and that it means, as Barak explained,

\footnotetext{
${ }^{89}$ Chaim Gans, The Limits of Nationalism (Cambridge: Cambridge University Press, 2002) at 141.

90 Ronald Dworkin, "Democracy and Religion: America and Israel" (14 September 2009), online: <http://www.youtube.com/watch? $=$ AU9kUlY-xUY >.

${ }^{91}$ A whole ministry- Ministry of the Absorption of Aliya- is dedicated to the task of promoting, processing and facilitating the immigration and integration of immigrants under the Law of Return. While it also deals with "returning citizens", the majority of the resources are dedicated to the absorption of Jewish immigrants. In 2012, the budget of the Ministry was NIS1.3 Billion (USD $\$ 330$ million). See "Budget Details for 2012", online: Ministry of Finance, <http://www.mof.gov.il/BudgetSite/StateBudget/Pages/Budget2009HPP.aspx > (in Hebrew). 92 Chaim Gans, From Richard Wagner to the Palestinian Right of Retum: Pbilosopbical Analysis of Israeli Public Affairs (in Hebrew) (Tel-Aviv: Am Oved Publisher, 2006) at 191.
} 
that "a special key to enter the state is given to those whom the state is their national homeland." 93 The question then becomes, who belongs to the national homeland, or whose national homeland is it? From Barak's statement, it seems that the main marker of belonging to the national homeland is the right to immigrate. Consequently, according to the Law of return and Barak's interpretation, Israel is the national homeland of Jews. What about the Palestinian citizens? Is Israel their national homeland given that they carry Israeli citizenship? If the right to immigrate is the decisive criteria, then they are excluded, for there are no legal provisions that grant them, or any other non-Jews this right. On the contrary, as will be explained in the next section, the acquisition of citizenship for Palestinians is made harder. On the other hand, if carrying the citizenship is what matters, and all citizens belong to the homeland, then this should also find some expression in the right to immigrate or at least immigration policy, for Barak tells us that this is the "special key" that is given to "to those whom the state is their national homeland". How does this square with the idea of universal citizenship? Barak does not deal with this question specifically. Barak in essence accepts one universal citizenship internally, but to reconcile the privileges of the Law of Return with this citizenship, he adds another layer, the national. This national layer determines who can join the People, and it relates the state to the nation and makes it the national homeland. If we go back to Walzer's quote from the beginning of this chapter, the "we" in the "we who are already members do the choosing" is determined by the national layer, which is solely Jewish. This raises serious questions about the People, for if the entry into the People is solely decided based on religious/ethno-national belonging, then one should wonder whether the People is as inclusive as some writers claim it is (the citizenry as the nationalists and liberal nationalists claim). The

${ }^{93} \mathrm{HCJ}$ 6698/96 'Adel Ka'dan v. Land Administration of Israel (2000), IsrSC 54 (1) 258; Aharon Barak, A Judge in a Democratic Society (In Hebrew) (Jerusalem: Nevo, 2004) at 161. 
seemingly universal citizenship that all members of the People share does not play a role when it comes to joining the People, and the citizenship's "universality" stops at the doors of the immigration policy. Other related questions emerge here: if the right to immigrate is the main marker of the national homeland, does that mean that Israel is not the homeland of the Palestinians living in it? As it stands today, it is less of a homeland for them (if at all) than anyone who converts to Judaism. ${ }^{94}$ This focus on the national aspect and its impact on the Palestinian citizens is best presented by Raef Zreik's argument -putting the Law of Return in the larger context of immigration to Israel and the expulsion and the blocking of return of the Palestinian refugees of 1948- that this Law embodies how "the negation of the Palestinian is built in Israeli law."95

\section{The Citizenship Law: Citizenship as a Category of Exclusion}

This section will focus on the citizenship regime in Israel pursuant to the Citizenship Law and its impact on defining the People. According to section 1 of the Law, citizenship is acquired by return, residence, birth, naturalization or grant. The law created different channels for acquisition of citizenship for those who lived in what became Israeli territory and for those who seek to immigrate. These channels are seemingly inclusive and neutral. However, when considered in light of sociological and political realities, a different picture emerges. It is essentially another manifestation of the oscillation between the state/citizenship/inclusiveness and ethnic revolution/particularism. But in this case also, the final result is not neutral, and it is more tilted to one side. In this section I will focus mostly on the acquisition of citizenship by

94 HCJ 2597/99 Tosbbeim v. Minister of Interior (2004) at para. 19 (in explaining that there should be not difference between those who convert in Israel and those who convert abroad, Barak said that " $[\mathrm{b}]$ oth converts joined the Jewish people and settled in the State of Israel; both of them are sons that are returning home.")

${ }^{95}$ Zreik, "Notes", supra note 85 at 42. 
residence and by naturalization through family reunification. I will also discuss loss of citizenship. A very brief discussion of the legal status of the Palestinians of East Jerusalem will be added in order to provide a clearer picture and to highlight trends in the policies.

\subsection{Acquisition of Citizenship According to Habitual Residence after the Creation of the State}

The Citizenship Law-1952 was enacted four years after the creation of the state. The law prescribed a number of ways to acquire citizenship. For Jews, it referred to the Law of Returm1950. Citizenship for this category was automatic and its application included Jews who were born and resident in Palestine and never immigrated. ${ }^{96}$ Acquisition of citizenship for non-Jews, mainly Palestinians, was regulated primarily through section 3 of the law which is titled "Citizenship by Residence in Israel". According to this section, non-Jews who were resident of Palestine had to meet a number of conditions in order to obtain Israeli citizenship. They had to be residents of Mandate Palestine; had to be registered on 1 March 1952 according to the Registration of Inbabitants Ordinance-1949; had to be residents of the country on the day the law came into force (14 July 1952), and had to be "in Israel, or in an area which became Israel territory after the establishment of the state, from the day of the establishment of the state to the day of the coming into force of this Law, or entered Israel lawfully during that period." While the law creates channels of inclusion and grants of citizenship, it is important to pay attention to the nuances, for in these nuances the flip side of citizenship can be seen clearly, for when it defines who is included, it also defines who is excluded.

This law essentially deprived all of the Palestinian refugees, who were approximately $80-85 \%$ of the Palestinian population living in the area that fell under Israeli control, of the 
right to citizenship. That is the first and the largest category excluded. The second category was the result of the conditions the law set out for a grant of citizenship by residence. For Palestinians who stayed in what became Israel after 1948, the conditions of section 3 proved to be hard to meet. Because of the war situation and the arbitrary policies adopted since 1948, many Palestinian residents did not meet the criteria. Many were not registered for various reasons, and among those who were registered, many could not prove continuous presence for four years. The result was that out of 175,000 Palestinian residents at the time the law entered into force, only 143,000 were entitled to citizenship. The remaining 32,000 had to naturalize in order to acquire citizenship. ${ }^{97}$ This group also lost most of their property because they were deemed "absentee" according to the Absentee Property Law-1950. Naturalization according to section 5 is subject to the discretion of the Minister of Interior and is not a matter of right. The fact that many Palestinians would have to naturalize in order to obtain citizenship was seen as a reasonable requirement by the Israeli leadership. In the course of the debate over the law, Moshe Haim Shapira, the Minister of Interior in 1950 said:

If the Arabs would really want to be citizens of the state of Israel they would find a way....It is not such an unreasonable demand from those who forsook their country while it was in flames to make the effort and acquire citizenship in the normal way without expecting the privilege of automatic citizenship. ${ }^{98}$

It is insightful here to contrast the automatic citizenship bestowed by the Law of Return upon any Jew, with the need "to make an effort" to acquire citizenship and that there should be no expectation of automatic citizenship for Palestinians. Citizenship, which could potentially

97 Uzi Benziman \& Atalla Mansour, Subtenants (in Hebrew) Jerusalem: Keter Publishing House, 1992) at 128. Although this Law left about $20 \%$ of the Palestinians without citizenship, the adoption of bills discussion earlier could have produced an even worse situation. The Bill of Citizenship Law-1950, would have granted citizenship to 63,000 Palestinians only out of a total of 167,000 Palestinians who lived in Israel then. See Hofnung, supra note 50 at 143 .

98 As cited in Ilan Pappe, "An Uneasy Coexistence: Arabs and Jews in the Early Years of Statehood" in S. Ilan Troen \& Noah Lucas, eds, Israel: The First Decade of Independence (Albany: State University of New York Press, 1995) 622 [Pappe, "Uneasy Coexistence”]. 
signify entry into the People, was not equal for all. The law showed unprecedented generosity to admit Jews into the People, for Palestinians, they had to find a way if "they really wanted to".

While most of those who were excluded from citizenship according to the 1952 law were granted citizenship after the law was amended in 1980, the impact of the law and its underlying message were obvious: it essentially blocked the return of the refugees by denying them citizenship, and reduced the number of those who were eligible for citizenship. The Government also implemented and interpreted the law in a manner that maximized the number of people who could not obtain citizenship. ${ }^{99}$ The conservative interpretation of the law which entailed the exclusion of those who left and returned to their homes before Israel took control of their areas, continued until 1962 when the Supreme Court decided, in a split decision, that this kind of absence was not the intention of the legislator. ${ }^{100}$

\subsection{Family Reunification}

Family reunification and eventually naturalization is one of the main channels of acquiring citizenship for non-Jews. The idea of family reunification was first introduced in

${ }_{99}$ This has sometimes created absurd situations, such as the case of Hanna Nakara, a prominent Haifa-based lawyer who was away from the city when it was occupied by the Hagana (precursors of the Israeli army) in April of 1948. Nakara could not go back to the city, so he went to a neighbouring town that was then evacuated. Since the road to Haifa was blocked, he went to Lebanon, and then returned to Haifa through Cyprus. After a short period he spent in detention, he resumed his legal practice, and argued hundreds of cases before Israeli courts including the Supreme Court. He also voted twice in the elections, ran as a candidate twice, once for the Knesset elections and once for municipal elections. In 1953 he applied for a passport. The Ministry of Interior rejected his passport application claiming he was not a citizen because he was not present in Israel since the day the state was declared and had only entered illegally in August 1948. Though the Supreme Court did reverse this decision, it was mostly based on a technicality. Substantively, the Court said it seemed that he did not meet the requirements. Nakara was lucky in that he appealed his exclusion from the Electors Registry for the 1951 elections for a similar reason. His legal challenge was successful, but the Court did not provide reasons. Thus there was a court decision accepting his appeal, but the reasoning was unclear. The Supreme Court decided, based on the earlier case, that the Minister cannot make a claim which was contrary to the outcome of the earlier decision. If the matter were to be examined de novo he would have been declared a non-citizen. See HCJ 112/52 Nakara v. Minister of Interior (1953), IsrSC 7, 955.

$100 \mathrm{HCJ}$ 328/60 Musa v. Minister of Interior (1962), IsrSC 16, 69. This decision was confirmed again in an additional hearing on the case- FH 3/63 Minister of Interior v Musa (1963), IsrSC 16, 2467. 
1949. The United Nations Conciliation Commission on Palestine convened a conference in Lausanne in Switzerland after the signing of the armistice agreements between Israel and the Arab states involved in the 1948 war (Egypt, Syria, Lebanon and Jordan). The refugee issue was discussed at that conference and the Israeli representative agreed to consider the repatriation of 100,000 refugees. This was the result of pressure by the United States and was aimed at appeasing the UN which was scheduled to decide on Israel's second application for UN membership. The first application was denied in December 1948 because, among other reasons, of the issue of refugee repatriation. After the membership application was approved, the proposal was withdrawn. Instead, the Israeli Government declared in August 1949 a family reunification plan that would allow for the return of a limited number of refugees who were split from their families during the war. The goal was to try to stop the trickle of returning refugees seeking to reunite with their families and to use this plan to reject any demands for blanket return. ${ }^{101}$ Since then, the only other option for acquiring citizenship (in addition to citizenship through residence) was through family reunion that culminates in citizenship, or sometimes residency, according to the status of the sponsor.

The government saw family reunification as a purely humanitarian scheme and not as a matter of right. The Minister of Interior has a very broad discretion in deciding which cases to approve. ${ }^{102}$ As a matter of policy, naturalization is the only way non-Jewish foreigners can acquire citizenship in Israel, and is the only way open to those who marry Israeli citizens. Until 1995, naturalization through family reunification applied solely to Palestinian citizens of Israel who wished to sponsor their spouses; non-Jewish spouses of Jewish Israeli citizens were able

101 Don Peretz, Israel and the Palestine Arabs (Washington D.C.: The Middle East Institute, 1958) at 50-51; Pappe, "Uneasy Coexistence", supra note 98 at 638; Robinson, supra note 43 at 82.

102 HCJ 758/88 Kendel v. Minister of Interior (1992), IsrSC 46(4) 505; HCJ 4156/01 Dimitrov v. Ministry of Interior (2002) IsrSC 56(6) 289. 
to get citizenship according to the Law of Return even if the sponsoring spouse did not immigrate. ${ }^{103}$ This situation changed with the adoption of a new policy in 1995 when all nonJewish spouses of Israeli citizens were required to go though naturalization through family reunification. Naturalization through family reunification is exceptionally important for the Palestinian citizens in Israel. The number of marriages between Palestinians who are Israeli citizens and Palestinians from the Occupied Palestinian Territory (OPT) is high.

In 2003 , after a suicide bombing in a restaurant where the perpetrator had obtained resident status in Israel after going through a family reunification process, the Knesset enacted the Citizenship and Entry to Israel Law (Temporary Order)-2003. It imposed an almost absolute prohibition on family reunification between Israeli citizens (most of whom are Palestinian citizens of Israel) and their spouses who are residents of the OPT. The law was first enacted for the period of one year, but was periodically and consistently renewed with some amendments. ${ }^{104}$ The 2007 amendment broadened the scope of the prohibition to include four new countries: Syria, Lebanon, Iraq and Iran. This prohibition did not include the Israeli settlers in the OPT. Essentially, the law instructed the Minister of Interior not to approve citizenship or residency applications to any Palestinian who is resident in the OPT or any of the four countries mentioned. The law provided for some minor exceptions and allowed for temporary permits to be issued for sponsored spouses who are above the age of 35 for males

\footnotetext{
103 Stamka, supra note 54. In 1995, due to a sharp increase in number of migrant workers claiming Israeli citizenship through "return" after they get married to Jewish Israelis, the Ministry of Interior, concerned about the authenticity of the marriages and motivations behind them, decided to adopt a more restrictive interpretation to the Law of Return. According to the new interpretation, non-Jewish spouses who are married to Jewish spouses can get citizenship through "return" only if the Jewish spouse is also an immigrant, otherwise they will have to go through a family reunification and naturalization process.

104 The Citizenship Law was first amended in 2005. See Citizenship and Entry to Israel Law (Temporary Order) (Amendment)- 2005.
} 
and 25 for females. The temporary permits have to be renewed periodically and they do not allow their holders to drive a car in Israel or benefit from healthcare.

The sweeping prohibition in the law solely affected the Palestinian minority. Its effect was disastrous for couples seeking family reunification. Couples who are within the age range of 25 for women and 35 for men had two choices only, either to move or risk criminal prosecution under the Entry to Israel Law -1952. For those above these ranges, the options were slightly better, but still grim: either move or obtain temporary permits that do not allow the holders the right to work or entitle them to healthcare or any social benefits. The Citizenship and Entry to Israel Law was criticized twice by the United Nations Human Rights Committee, ${ }^{105}$ and twice by the United Nations Committee on the Elimination of Racial Discrimination. ${ }^{106}$

\subsubsection{Family Reunification and the Court}

The Citizenship and Entry to Israel Law was challenged twice before the Supreme Court. The discussion and the argument presented by the Court in these cases provide indications about who is thought of as belonging to the People and how this law fits the understanding of the People. In the first challenge, six out of the 11 Justices found that the law violated the right to family life and the right to equality. ${ }^{107}$ These rights are derived from the right to dignity which is protected under Basic Law: Human Dignity and Freedom. The six Justices found that the violations were not proportionate and therefore could not meet the requirements of the

\footnotetext{
105 Human Rights Committee, Concluding Observations of the Human Rights Committee' CCPR, 99th Sess, UN Doc CCPR/C/ISR/CO/3, (2010), $\quad$ online: <http://unispal.un.org/UNISPAL.NSF/0/51410EBD25FCE78F85257770007194A8>; Human Rights Committee, Concluding Observations of the Human Rights Committee: Israel, CCPR, 78 th Sess, UN Doc CCPR/CO/78/ISR (2003) online: <http://unispal.un.org/UNISPAL.NSF/0/2E5A21A17AEBOC0285256D7F004F4D61>.

106 Committee on the Elimination of Racial Discrimination, Concluding Observations of the Committee on the Elimination of Racial Discrimination: Israel, CERD, $70^{\text {th }}$ Sess, UN Doc CERD/C/ISR/CO/13, (2007) online: < http://unispal.un.org/UNISPAL.NSF/0/041AB84D2F05080C85257302004A.9963>.

${ }_{107} \mathrm{HCJ}$ 7052/03 Adalab v Minister of Interior (2006), IsrSC 61(2) 202.
} 
"limitation clause" which prescribes that any violation should be "by a law befitting the values of the State of Israel, enacted for a proper purpose, and to an extent no greater than is required." ${ }^{\prime 108}$ However, one of the six, Justice Levi, decided, despite the violation, to join the majority in rejecting the petition since the law was a temporary one which was about to expire. At the same time he recommended enacting a new arrangement that entails a more proportionate infringement on the rights. The other five majority Justices decided that either there was no violation of constitutional rights, or that any violation by the impugned law was justified since it met the requirements of the limitation clause. Four of these Justices distinguished between the right to family life and the right to family life in Israel. The right to family life, they ruled, does not mean that the right should necessarily be exercised in Israel. As long as the right could be exercised elsewhere, there is no violation. The final outcome was that the petition was rejected and the constitutionality of the legislation was upheld.

The second challenge came in 2007 after the Knesset extended the law and broadened its scope. ${ }^{109}$ Again, in a split decision of six to five, the Supreme Court upheld the constitutionality of the amended law. Citing the earlier decision (Adalab), the majority Justices with the exception of Justice Rivlin- distinguished between the right to family life and the right of citizens to exercise this right with a foreign spouse in Israel. ${ }^{110}$ The latter right, they decided, is not a constitutional right in Israel. Similarly, the majority decided that there was no violation of the right to equality in this case. They acknowledged that the law affects almost solely the Palestinian citizens and not the Jewish citizens, but they concluded that in this case the distinction is based on the fact that those citizens decided to marry what the Justices called

\footnotetext{
108 For a detailed discussion of the "limitation clause", see chapter VI.

109 HCJ 466/07 Galon v. The Attorney General (2012).

${ }^{110}$ Justice Rivlin found that the right was violated but the violation met the requirements of the limitation clause.
} 
"enemy subjects". The reasoning provided in these two decisions raise a number of issues about the nature of the citizenship of the Palestinians in Israel, which seems to be contingent, conditional and partial. This also raises the question of whether, and to what extent, Palestinians are seen as part of the People. This theme will be the focus of the discussion below.

\subsubsection{The Right to Family Life and the Image of the People}

The Court distinguished between the right to family life and the right to family life in Israel. In making this distinction, the majority attributed significant importance to the fact that the issue is one of immigration law, which, as a rule of international law, is a matter of sovereignty; the state has the right to decide who can enter or immigrate to it, and under what conditions. Relying on this principle, the majority Justices argued that the scope of the right to family life should not be construed to include the right to bring a foreign spouse into the country in order to avoid conflict with state sovereignty. The right to family life, they said, is a broad category and includes many aspects such as the right to marry, but in this context, family reunification that entails the right of a citizen or a resident to bring to Israel his or her foreign spouse is only on the periphery of the right to family life and is not part of its core. The Justices were concerned that if the right to family life includes the right to family reunification as a constitutional right, then the state, and the relevant Minister, cannot fulfil their role as the gatekeepers.

This concern is problematic on a number of levels, but here I will focus on one aspectthe discretion of the Minister of Interior as a gatekeeper. A look at the Law of Return and the case law shows that the Israeli legal system accepts limiting executive discretion in the case of 
immigration (of Jews only) to the point of limiting the power of the state. It also accepts the importance of the unity of the family unit in the process of immigration. The Supreme Court acknowledged that it is an immigration law that limits the powers of the state. ${ }^{111}$ This could also be discerned from another decision by the Supreme Court dealing with the question of conversion to Judaism in the context of eligibility under the Law of Return. As mentioned earlier, the Supreme Court has ruled that the state should recognize non-Orthodox conversion if the conversion or its final stages are conducted by recognized Jewish communities outside Israel. ${ }^{112}$ Since conversion determines eligibility to immigrate as a matter of right, what the Court did was delegate part of state sovereignty to foreign institutions - the institutions of Jewish communities outside Israel - over which the state has no control. Limiting the state's power over immigration is therefore not a novel occurrence in Israel. ${ }^{113}$

The Supreme Court, therefore, tolerates limiting the powers of the state when it comes to Jewish immigration only, because the state is defined as a Jewish state, and because Jewish immigration is closely related to Jewish self-determination. ${ }^{114}$ The fact that the rights under the Law of Return are extended to non-Jewish family members means that the right to family life for potential Jewish citizens, is broader, stronger and more valuable than the right to family life of Palestinian citizens seeking to sponsor their non-Israeli spouses. The state is willing to recognize, in the context of immigration, the rights of Jewish individuals who are not citizens, yet, it is not willing to recognize similar rights for its Palestinian citizens. At one extreme, the Law of Return almost eliminates the discretion of the executive in that it provides very little

111 Pesro, supra note 84.

112 Tosbbeim, supra note 54

113 It should be noted the Justice Grunis, who was in the minority in this case, raised the concern about supervision of the conversion process by the state. His position is somewhat consistent with his position in Galon, supra note 109.

114 Tosbbeim, supra note 54 at 733. 
room to deny admission or applications for citizenship to Jewish individuals and their families. At the other extreme, the Citizenship and Entry to Israel Law eliminates the discretion of the executive in that it provides almost no room for granting status to spouses of (mostly Palestinians) Israeli citizens who are originally in the OPT or the other four countries mentioned.

Concerns about sovereignty arise when it comes to family reunification of Palestinians; it does not seem to be a serious concern when Jewish immigration is involved. The question then becomes, what is the nature of this sovereignty? Why does it tolerate and promote one kind of immigration and sees other kinds as a thereat? If we take immigration as one marker of sovereignty, then it is plausible that the sovereignty at issue is Jewish sovereignty exercised by the People that only includes Jews as its members.

\subsubsection{Comparative Law: Citizens or Residents?}

In justifying their position on limiting the scope of the right to family life, the majority Justices relied heavily on comparative law, mainly decisions of UK Courts, and the European Court of Human Rights (ECtHR). The Justices especially emphasized the jurisprudence of the ECtHR since it deals specifically with the interpretation of Article 8 of the European Convention of Human Rights which protects the right to family life. This article was often discussed in the context of Israeli immigration cases. In addition to selectivity in the choice of the cases cited and quoted to a point that one can say that the cases chosen did not reflect the state of the EU law, another trend could be observed. ${ }^{115}$ Most of the European cases cited dealt with situations where foreigners sought to enter the country to join long term residents or naturalized

\footnotetext{
115 For a more elaborate discussion of this point, see, Mazen Masri, "Love Suspended: Demography, Comparative Law, and Palestinian Couples in the Israeli Supreme Court" (2013) 22:3 Social and Legal Studies 309.
} 
citizens $^{116}$ One of the leading cases that was referred to and quoted by a number of Justices was Case C-540/03 of the European Court of Justice which dealt with European Union Directive 2003/86/EC. This Directive deals with family reunification between foreign residents of the EU countries and their foreign spouses. Even in the one case that concerned a citizen of an EU country, the ECtHR accepted the distinction between naturalized citizens and citizens by birth. ${ }^{117}$ There are strong grounds to disagree with the legitimacy or adequacy of this distinction between citizens and residents, and between naturalized citizens and citizens by birth. It is however important to highlight for the purpose of the dissertation that this distinction is based on the premise that citizens, especially citizens by birth, have fewer links with other states where they can exercise family life.

The use of these European cases in order to justify limiting the right to Palestinian family life in Israel carries a significant meaning. It essentially means that the Justices of the Supreme Court of Israel relied mainly on cases that deal with long term residents, refugees or naturalized citizens when they were examining a law that applies to members of the Palestinian minority in Israel, which is a homeland minority and has no connections to other states. ${ }^{118}$ This choice of comparators is an indication that the Court saw members of the Palestinian minority as outsiders; despite holding formal citizenship, the status of this citizenship is not similar to the status of the Jewish citizenship. The Court approached the status as that of immigrants, or naturalized citizens at best. This observation is similar to ones made by Hassan Jabareen in his

$116 Z$. and T. $v$ The United Kingdom (dec), No 27034/05 (28 February 2006); Priya v Denmark (dec), No 13594/03 (6 July 2006); ECJ European Parliament $v$ Council of the European Union, C-540/03, [2006] I-5769; Huang v Secretary of State for the Home Department, [2007] AC 167 (HL):; Abdulaziz, Cabales and Balkandali v UK (1985) 7 EHRR 471. 117 Abdulaziz, ibid at 88.

118 While the Palestinian citizens have family and cultural connections to the OPT Palestinians, their origin is not from the OPT. In fact, many OPT Palestinians are refugees who originate from areas that are now part of Istael. 
assessment of the jurisprudence of the Supreme Court, ${ }^{119}$ and it raises questions about whether this kind of membership counts as being part of the People.

\subsection{Loss (and possible) Reacquisition of Citizenship}

The issue of the loss of citizenship is equally important in discussions on citizenship laws in the context of determining who is the People. As in the acquisition of citizenship, the loss of citizenship plays a role in designing the political community and its identity. It is therefore useful to examine some aspects of Israeli law concerning loss of citizenship. As in the case of entering into the People through the combination of the Law of Return and the Citizenship Law, the apparently neutral laws operate in a manner that facilitates loss of citizenship for Palestinian citizens.

\subsubsection{Ineligibility to Citizenship for Second Generation Descendants Born Outside Israel}

In addition to the exclusion of Palestinian refugees from eligibility for citizenship by the Citizenship Law, the current provisions of the law have an exclusionary effect on nonJewish, mainly Palestinians citizens, born outside Israel. Israeli citizens pass on their citizenship to their children according to section 4 of the Citizenship Law which regulates the eligibility for citizenship by birth. According to this section, anyone who is born in Israel to an Israeli parent is automatically a citizen. For those born to Israeli parents outside Israel, section 4(a)(2) provides that they are eligible for Israeli citizenship if one of the parents became a citizen through "return", residence in Israel, naturalization, or birth in Israel. This list excludes those who have acquired their citizenship through birth outside Israel. The practical implications are that the second generation of Israeli citizens born outside the country are not entitled to

\footnotetext{
${ }^{119}$ Hassan Jabareen, "The Future of Arab Citizenship in Israel: Jewish-Zionist Time in a Place with no Palestinian Memory" in Daniel Levy \& Yifaat Weiss, eds. Challenging Etbnic Citizenship (New York: Berghahen Books, 2002) 196.
} 
citizenship. ${ }^{120}$ Section 9 of the Law allows the Minister of Interior to grant Israeli citizenship to those who are second generation to be born outside Israel up to their $22^{\text {nd }}$ birthday, but these powers are a matter of discretion and not a matter of right. This may sound like a minor issue since it is reasonable that those affected have established residence in a different country and most likely hold its citizenship. Still, one can see the discriminatory effect of this provision by taking into consideration the Law of Return. The exclusion affects only non-Jewish citizens since Jewish citizens who cannot acquire citizenship according to section 4 (a) (birth outside of Israel) are always eligible for Israeli citizenship according to the Law of Return. This discriminatory effect is even more relevant today with the globalized reality and the significant increase in the movement of people across borders. But more importantly, the combination of the Citizenship Law and the Law of Return means that entitlement to Israeli citizenship for the descendants of non-Jewish Israelis born abroad comes to an end while entitlement to Israeli citizenship for Jews in the same situation is guaranteed. The trend is to decrease entitlement to citizenship for the descendants of non-Jewish Israeli citizens and keep it open and flexible for Jews. In a sense, this is a reflection of the flexibility of the openness and closure of the People. When it comes to Jews, the law makes accommodations to ensure that Jewish membership in the People is continuous. When it comes to Palestinian citizens, the law operates in the opposite manner.

It seems that this was the intention of the Knesset when it amended section 4(a)(2) of the Citizenship Law in 1980. Before this amendment, Israeli citizens were able to pass on citizenship to their descendants born outside Israel (with the exception of a number of states which were defined as enemy states) in an unlimited manner. The motivation behind the 1980

120 Rubenstein and Medina think that this arrangement is far reaching, but they do not deal with its discriminatory aspect. See Rubenstein and Medina, supra note 76 at 1103. 
amendment, which is the law today, was to encourage descendants of (Jewish) Israelis to move back to the country. The explanatory note that accompanied the amending Bill explained that automatic and unlimited citizenship through birth "constitutes a negative factor in the chances of those citizens to make aliya [immigrate] back to the country." ${ }^{\prime 21}$ The reason being that as citizens they have to serve in the army, so they would avoid even short visits in order to avoid military service. But as non-citizens (but potential immigrants), they will be able to visit without the threat of being recruited to the army and maintain a stronger link with the country which at some point might lead to them settling in Israel. In essence, this arrangement which restricts Palestinian eligibility for citizenship was enacted in order to promote Jewish immigration based on the Law of Return.

\subsubsection{Revocation of Citizenship}

The provisions regarding revocation of citizenship and the way they are used are another indication regarding who is considered to be part of the People in Israel. Revocation of citizenship is regulated by section 11 of the Citizenship Law. When it was initially enacted, the law included a provision [section 11(a)(3)] that allowed for the revocation of citizenship of any citizen who "has committed an act constituting a breach of loyalty to the State of Israel". The power to do so was granted to the District Court at the request of the Minister of Interior. This provision was amended in 1980. The amendment transferred the power to revoke citizenship to the Minister and broadened the scope of the grounds for revocation. In addition to the "breach of loyalty" grounds, the amended section 11(a) provided that if a citizen visits any of the countries mentioned in the Prevention of Infiltration Act -1954, he/she will be seen as

121 Citizenship Law Bill (Amendment no. 4) - 1979, Hatsa'ot Hok 1419, 22.10.1979, 32. 
giving up his/her citizenship, and it would be cancelled from the day he/she leaves. These countries include Lebanon, Syria, Jordan, Egypt, Jordan, Saudi Arabia, Iraq and Yemen.

In 2008 , the law was amended again. The amendment started as a private bill which was submitted in 2006, as a reaction to the Palestinian citizens' opposition to the Second Lebanon War and the operations of the Israeli army during the Second Intifada. The bill stated that the reason for the amendment is to provide more effective tools to the authorities to deal with Israeli citizens who express solidarity with "the enemies of the state and terror organizations that attack it." ${ }^{122}$ The amendment transferred the power to revoke citizenship to the Administrative Affairs Court upon the application of the Minister of Interior and with the approval of the Attorney General. What appears as an improvement -since the Court is a more appropriate body to deal with such a significant act- was in fact a setback. The amendment introduced new elements that will make revocation of citizenship easier. It provided a more concrete but very broad definition to the terms "breach of loyalty". "Breach of loyalty" as defined in the amendment includes any "act of terror" as defined by the Probibition of Terror Financing Law-2005, and any support or solicitation of "acts of terror". The definition of "act of terror" is very broad, and in essence, what the amendment did was to broaden the grounds for revocation of citizenship. ${ }^{123}$ The amendment also provided that the Court may deviate from the regular rules of evidence, and that secret evidence is admissible in an application to revoke citizenship (section 11(e)). In 2011, the Law was amended again and

\footnotetext{
122 It is important to mention that while this was clear in the initial Private Bill the was submitted by MK Gilad Ardan, this same motive was not included in the Bill that was published in the "Bills" section of the official publications "Rashomot", although the content of the Bill and the amendment that was adopted were essentially the same. For MK Gilad Ardan's Bill, online: <http://www.knesset.gov.il/privatelaw/data/17/1708.rtf>, for the Bill as was officially published see Bill for Citizenship Act (Amendment no. 9) (Powers to Nullify Citizensbip)-2007 Hatz'aot Hok-Knesset 175, 10.10.2007.

${ }^{123}$ For the definition of "an act of terrorism", see Section 1 of the Probibition of Terror Financing Law-2005.
} 
section $11 \mathrm{~A}$ was added. This new provision introduces revocation of citizenship as a possible penalty if citizens are convicted of "act of terror" or treason or spying. No separate legal proceedings are needed, and the revocation an be done as part of criminal proceedings.

A search in legal databases and news reports shows that since the creation of the state, that trend has been that only Palestinian citizens lost their citizenship on the ground of "breach of loyalty", terrorism or visits to enemy states. ${ }^{124}$ The 2008 and 2011 amendments are new, and there is no case law or credible data on whether they have been used to revoke citizenship or the manner in which they have been used, but it seems, from the initial private member bill that produced the 2008 amendment and from the context, that they are tailored to deal with Palestinian citizens. These observations show that the law on revocation of citizenship has been designed in such a way to broaden its applicability to one group, Palestinian citizens. To the extent Palestinian citizens are part of the People, the law makes it easier to expunge them.

\subsubsection{Regaining Lost Citizenship}

Another aspect of citizenship and immigration laws and policies which might shed light on their role in shaping the People is the ability to regain citizenship for citizens who lost it. An examination of the judicial treatment of this question and the arguments that the Ministry of Interior raised in the relevant cases exposes differential treatment based on religion and national belonging making it easier for Jews to re-join the People, while making it impossible for Palestinians in the same situation.

Neither the Law of Retum nor the Citizenship Law has any stipulations about a situation where a citizen who gave up his/her citizenship wishes to reacquire it. However, for Jewish

${ }^{124}$ See for example, "Minister of Interior Started Revoking the Citizenship of 4 Israeli Arabs", Ynet (5 May 2009), online: <http://www.ynet.co.il/articles/0,7340,L-3711162,00.html>. 
Israeli citizens and their descendants who gave up their citizenship, the question is simple as it is falls under the Law of Return. The Ministry of Interior's internal rules allow former Israeli citizens who gave up their citizenship to reacquire it if they meet the criteria of the Law of Return. ${ }^{125}$ This policy was never challenged. ${ }^{126}$ However, when it comes to Palestinians who gave up their Israeli citizenship and sought to regain it, the state's arguments and the Court's reasoning take a different direction. In a number of cases where Palestinians who gave up their citizenship sought to reacquire it, the Minister of Interior refused their requests because the petitioners gave up their citizenship "out of free will and with informed intention." 127 The Court affirmed the Minister's position and added that the Minister is under no obligation to return the citizenship. ${ }^{128}$ The Court treated the petitioners in these cases as foreign nationals, and in one case even refused the request to issue a temporary resident visa. ${ }^{129}$

The contrast between the ability to regain citizenship for Jews who relinquished it and the impossibility of even getting a temporary resident visa for Palestinians in the same situation provides an insight into who the state and the law sees as part of the People. For Jews, even if they formally give up their formal link to the state, re-joining the People is a matter of right

125 Procedure for Approval of an Application for an Immigrant Visa Another Time in Israel and Overseas Missions, (Procedure number 5.2.0002) (1 August 2005) online: http://piba.gov.il/Regulations/67.pdf (in Hebrew).

${ }^{126}$ See Zvidovsky, supra note 58. In this case, a woman who was a Jewish Israeli citizen converted to Christianity, moved abroad and gave up her citizenship, and then demanded to reacquire her citizenship. The focus was on the question whether the petitioner "belonged to any other religion" or not, and consequently, whether she is Jewish or not. Only one Justice (Justice Meltzer) expressed some discomfort the automatic reacquisition of citizenship.

127 See, HCJ 7164/02 Joumis v. Minister of Interior (2004), IsrSc 59(2) 232; HCJ 9037/02 Hujeirat Raf'a v. Ministry of Interior (2006); HCJ 10609/07 Zo'abi v. Minister of Interior (2011) [Zo'abi].

128 One exception to this policy is the case of women who gave up their citizenship and moved to the Occupied Palestinian Territories to join their husbands and then got a divorce afterwards. This is a very narrow category and is based on the fact that these women were forced to give up their citizenship to be registered in the Residents Registry administered by the Military Commander of the Occupied Territory, and because most of them were not aware of the fact that they were signing waiver forms. But this remains a very narrow category applicable only in extraordinary circumstances. It is the exception to the rule that non-Jews cannot reacquire their citizenship as opposed to Jews who can go through the Law of Retum. See HCJ 2271/98 Abed v. Minister of Interior (2001), IsrSC 55(5) 778.

${ }^{129} \mathrm{Zo}$ 'abi, supra note 127. 
and a short technical procedure, even if they are established elsewhere and have other citizenships. For Palestinians, even temporary residence is impossible. Given that in two similar cases one person can regain citizenship and the other cannot even reside in the country, the People operating here is obviously the Jewish people. These starkly contrasting results are part of the logic of the Law of Return. Neither the Ministry, nor the legislature, nor the Court, saw any problem with these results, and did not acknowledge that the Palestinian individual denied repatriation had links to the state and to a group living there is telling evidence that none of these arms of the state saw him/her as belonging to the People.

\subsection{The Status of the Palestinians of East Jerusalem}

Although most East Jerusalem Palestinians are not Israeli citizens, it is useful to provide a brief overview of the way the Israeli authorities approach their legal status. The approach echoes the policies that were implemented regarding the Palestinian citizens of Israel, and the trends are similar: to increase the number of Jews in Jerusalem while reducing the number of Palestinians.

Days after the occupation of East Jerusalem in June 1967, the Israeli Government issued an order that extends the validity of Israeli law to the area of Jerusalem and its surrounding villages and made them part of the territory of the state. ${ }^{130}$ As in 1948 , a census was conducted shortly after. ${ }^{131}$ All of those who were present and were counted in the census were given resident status according to the Entry to Israel Law-1952 - a status that is given to foreign nationals who seek to enter Israel at the discretion of the Minister of Interior. Granting this status essentially made their legal status akin to immigrants, although some Jerusalemite families could trace their roots in Jerusalem back to the Islamic conquest of $637 \mathrm{AD}$. This

130 Governance and Law Order (1)-1967.

${ }^{131} \mathrm{HCJ}$ 282/88 Awad v. Prime Minister and Minister of Interior (1988), IsrSC 42(2) 424. 
status was also very weak and made the East Jerusalem residents vulnerable. The granting of the status was subject to the broad discretion of the Minister of Interior, and it could be revoked if the residents spent a long period of time outside Israel or if they acquired a foreign citizenship. ${ }^{132}$ It could also be revoked for what is considered "breach of loyalty" or other security grounds. ${ }^{133}$ The Absentee Property Law was also applied to East Jerusalem, and all of those who were not physically present in 1967 lost their property. ${ }^{134}$

This outcome was not a mere coincidence, but an outcome of a planned policy that was adopted by the Israeli Government. It entailed reducing the number of the Palestinians living in East Jerusalem and the amount of land they hold, and maintaining a certain ratio of Jewish and Palestinian population and property. The natural result of this policy was massive land confiscation and the construction of settlements for Jews only. ${ }^{135}$

\subsection{Summary}

As the main piece of legislation that regulates citizenship, the Citizenship Law and its subsequent amendments did provide legal citizenship status for the Palestinians who stayed in what became Israel in 1948. The operation of the law granting what apparently seems to be a universal citizenship, however, was characterized by three important dynamics that diminish the universality of the citizenship it grants. The first one is the inseparable connection between the Citizenship Law and the Law of Return which gives some privileges to Jews in access to citizenship, essentially creating categories of citizenship diminishing the universality of

132 Ibid; HCJ 209/73 Odeb (Lafi) v. Minister of Interior (1973), IsrSC 28(1) 13.

133 See for example the case of Palestinian Jerusalemites who won the elections for the Palestinian Legislative Council of the Palestinian Authority on a slate affiliated with Hamas. The challenge for revocation of status is still pending before the Supreme Court (HCJ 7803/06 Abu Arafeh v. Minister of Interior).

${ }^{134}$ Law and Administration Arrangements Law [Consolidated Version] -1970.

135 The current municipal policy in Jerusalem is to maintain a $28 \%$ Palestinian $72 \%$ Jews ratio among the population in the city. See Amir Cheshin, Municipal Policies in Jerusalem - An Account from Within Jerusalem, PASSIA, 1998) at 15. See also Michael Dumper, The Politics of Jerusalem Since 1967 (New York: Columbia University Press, 1997) at 121. 
citizenship that the law grants. The second dynamic is restricting the category of Palestinians eligible for citizenship using various restrictive criteria, compared to open and automatic citizenship for Jews. Judicial treatment of the law and immigration policy confirms this trend. This can be seen most clearly in the cases dealing with family reunification, and the judicial approach to attempts to reacquire citizenship. The third dynamic is making the loss of citizenship easier for Palestinian citizens and blocking any attempts to regain it. The inevitable conclusion in this case is that the Citizenship Law applies in a different manner to the population in the country depending on the identity of the individual. For Jews it is very inclusive and seeks to remove barriers to their access to citizenship. For Palestinians on the other hand, the law is designed in a way to reduce their numbers on all levels. In addition to the impact on the composition of the population, the fact that these dynamics are the product of laws enacted by the state and enforced by courts indicates how these bodies shape the People.

\section{Demography and Equality}

\subsection{Demography as the Comerstone of Israeli Policy}

Historically, demography has been always present as a concern in the decision-making process in Israel. Demographic concerns could be traced back to the Zionist institutions that preceded the creation of the State of Israel in $1948 .{ }^{136}$ Some historians see the ethnic cleansing that accompanied war in 1948 as part of this demographic policy. ${ }^{137}$ Demographic considerations were at the heart of many state policies in almost all areas that could be used to

136 See e.g. Ben Halpern, The Idea of the Jewish State, 2nd ed (Cambridge, MA: Harvard University Press, 1969).

${ }^{137}$ See Pappe, "The Ethnic Cleansing", supra note 15; Masalha, "The Expulsion", supra note 16; Masalha, "A Land", supra note 23. 
increase the number of Jews and reduce the number of Palestinians. ${ }^{138}$ This can be seen clearly in areas such as family planning and health policy (especially women's health). As early as 1949 , the state implemented policies to encourage Jewish population growth in addition to immigration. Ben Gurion announced a monetary prize for "heroine mothers" who have ten children or more. This prize was subsequently cancelled because most of those who claimed it were Palestinian. ${ }^{139}$ Ben Gurion is also known for his famous statement that any Jewish woman with less than "four healthy children is shirking her duty to the nation". ${ }^{140}$ Until the 1980 s, contraceptives were available through private health providers only in order to promote natural growth. Family planning schemes disproportionately targeted Palestinian families rather than Jewish families despite the shortage of general health facilities designated to serve Palestinians. ${ }^{141}$ Pro-natalist trends amongst Jews were also promoted through differential allocation of social support for children. ${ }^{142}$ Since 1967 , the Government has been advised by

\footnotetext{
138 See for example Section 10 of Israel Government Resolution no. 428 (4 April 1967) which provides that "[ $t]$ he Government Ministries will necessarily be subject to the understanding of the Center in matters and plans of action, dealt with in the Ministries, which influence the area of demographic policy. Every office whose activities touch on the demographic issue shall appoint one of its senior workers as a permanent coordinator with the Center for demographic issues." See also Section D(1) of Israel Government Resolution (11 May 1986) which provides that "[t]his policy [of increasing the growth of the Jewish population] will ensure that activities run by Ministries and other public bodies in the fields of health, education, labor and welfare, economic development, etc., which influence population growth and other demographic issues, be coordinated by the Demographic Center to conform with the general goals of the demographic policy." Printed in Sergio DellaPergola, Jewish Demographic Policies: Population Trends and Options in Israel and in the Diaspora Jerusalem: The Jewish People Policy Institute, 2011) at 306-311, online: <http://jppi.org.il/uploads/Jewish_Demographic_Policies.pdf>.

139 Rhoda Ann Kanaaneh, Birthing the Nation: Strategies of Palestinian Women In Israel (Berkeley: University of California Press, 2002) at 35.

140 David Ben Gurion, Israel: A Personal History (New York: Funk \& Wagnalls Inc., 1971) at 839.

${ }^{141}$ Kanaaneh, supra note 139 at 37.

142 Higher Children Allowances for Jewish children (those whose parents served in the Army or are ultraOrthodox Yeshiva students) was the norm until the mid-1990s. This policy was confirmed by the Supreme Court in HCJ 200/83 Wattad v. Minister of Finance (1984), IsrSC 28(3) 113. After the equalization in the mid 1990s, there was another attempt in 2002 to implement a differential scheme that prefers the children of those who served in the army. This attempt was challenged in Court, but the whole plan was abandoned (HCJ 4822/02 The National Committee of Arab Mayors v. Speaker of the Knesset (2003)(petition dismissed)). In 2009, the National Insurance Act was amended to include a $60 \%$ reduction in the allowance for children who do not take the mandatory vaccinations. This new measure disproportionately affects the Bedouin children because of the lack of the health facilities in their areas (see HCJ 7245/10, Adalah v. Minister of Welfare and Social Affairs (case pending)).
} 
"the Centre for Demographic Problems" on issues of demographic planning with the goal of increasing Jewish population growth and reducing Palestinian population growth. ${ }^{143}$ The Centre was a department of the Prime Minister Office and included members of the Jewish Agency in its membership. ${ }^{144}$ The Demography Centre was revived in 2002 after it was disbanded in the late $1990 \mathrm{~s} .{ }^{145}$

Zoning and land policy are also influenced by demographic considerations where the goal is usually to reduce the concentration of Palestinians in certain areas and to avoid the creation of contiguous Palestinian populations centres. This is usually done through the policy known as "judaization" which had its beginnings in the 1950s and became full-fledged official policy in the 1970s and 1980s when the Government initiated and carried out plans that aimed at "judaizing" the Galilee. ${ }^{146}$ This policy is still the official policy today, though it was re-named "development" and the Jewish population was re-named "quality groups of young people who finished their army service", and the emphasis shifted to include the Naqab (Negev) ${ }^{147}$ Even surveys and statistics are usually designed to achieve demographic goals of reducing the

143 Susan Martha Kahn, Reproducing Jews: A Cultural Account of Assisted Conception in Israel (Durham, NC: Duke University Press, 2000) at 4; Gila Strupler, 'Israel's Demographic Policy in the Area of Birth and Women and Minority Rights' (in Hebrew) (2006) 10 Misphat Umimshal 473.

144 Israel Government Resolution no. 428 (4 April 1967), printed in DellaPergola, supra note 138 at 306-309.

145 Ze'ev Klein, "Because of the Decrease in the Birth-rate: Benizri Convened the Demography Council" (3 September 2002) Globes, online: <http://www.globes.co.il/news/article.aspx?did=615868>.

146 See e.g. Ghazi Falah, "Israeli 'Judaization' Policy in Galilee" (1991) 20:4 Journal of Palestine Studies 69; Ahmad Sa'di, 'The Koenig Report and Israeli Policy Towards the Palestinian Minority, 1065-1976: Old Wine in New Bottles' (2003) 25:3 Arab Studies Quarterly 51; Oren Yiftachel, Ethnocracy: Land and Identity Politics in Israel/ Palestine (Philadelphia, PA: University of Pennsylvania Press, 2006).

147 The website of the Ministry for the Development of the Negev and the Galilee states that "one of the ways to bring about change in the towns in the areas of the Negev and Galilee is through bringing quality population as seeds for settlements that would gradually grow and change the demographic map..." The Ministry sees these "quality seeds as the spearhead for demographic change and is interested in bringing them to settle in settlements in the Negev and Galilee." "Demographic Growth and Settlement", online: Ministry for the Development of the Negev and the Galilee <http://www.vpmo.gov.il/Negev/listProject/Pages/settlementandemogrhpy.aspx> [translated by author]. 
number of Palestinians and increasing the number of Jews. ${ }^{148}$ The Gaza Disengagement Plan was also mainly motivated by demographic concerns. ${ }^{149}$ Most recently, the demography argument was also used as a catalyst to devise and implement policies to prevent the refugee claimants from African countries from coming to Israel through the southern border. The refugee claimants were presented as a threat to the Jewishness of the state. ${ }^{150}$

The Law of Return and the related policies that aim at promoting Jewish immigration also provide a clear indication about demography as an important consideration since one of their main goals is to maintain a strong Jewish majority. Although the Law is usually presented as one that intends to provide persecuted Jews and Jewish refugees with a safe haven where they can be safe from persecution, ${ }^{151}$ the broad scope of the right and the financial incentives tied to it show that the main objective goes beyond that. Similarly, the policies of the successive Israeli governments also indicate that this is not the main objective. In the late 1980s for example, the Israeli government applied pressure on the US Administration to deny Soviet Jewish emigrants refugee status in the US because they have the right to immigrate to Israel. The law was used as a tool to deny emigrants from the USSR the chance to choose the place to start their new lives in order to increase the Jewish population in Israel. ${ }^{152}$

\subsection{Demography and the Supreme Court}

148 See, Leibler, supra note 45; see also Asher Cohen \& Bernard Susser, "Jews and Others: Non-Jewish Jews in Israel" (2009) 15:1 Israel Affairs 52.

149 "Two. The purpose of the plan is to lead to a better security, political, economic and demographic situation" in "Disengagement Plan of Prime Minister Ariel Sharon - Revised" (28 May 2004), online: Knesset Website <http://www.knesset.gov.il/process/docs/DisengageSharon eng revised.htm>.

150 Talila Nesher, "Netanyahu: Israel Could be Overrun by African Infiltrators", Haaretz (21 May 2012) online: http://www.haaretz.com/news/diplomacy-defense/netanyahu-israel-could-be-overrun-by-african-infiltrators1.431589

151 Rubenstein, "Israeli Nationality", supra note 68 at 160, n 4.

152 Clive Jones, Soviet Jewish Aliya 1989-1992: Impact and Implications for Israel and the Middle East (London: Frank Cass, 1996) at 47-48. 
A Jewish majority, as mentioned earlier, is one of the most important meanings of the Jewish state. It is a constitutional given, and its promotion is a constitutional precept embodied in the idea of "ingathering the exiles." For many, and indeed according to the Supreme Court of Israel, this is seen as Israel's raison d'etre, and one of the foremost manifestations of the Jewishness of the state. ${ }^{153}$ While many decisions emphasize the significance of the Jewish majority as an essential component of Israel's definition as a Jewish state and the importance of maintaining this majority, ${ }^{154}$ there have been no decisions on what could be considered legitimate means in maintaining it, nor has there been any discussion about what that means for the Palestinian citizens. The Court, nonetheless, discussed the issue in obiter in the two cases that dealt with the constitutionality of the Citizenship and Entry to Israel Law-2003.

The discussion arose in the context of the objective of the Law in the Adalab and Galon cases. Some of the petitioners in Adalab argued that the main drive behind the legislation is not security but demography. This argument was rejected and the Justices accepted the state's position that security concerns are what triggered the enactment of the law. Despite emphasizing the security considerations in its arguments before the Court, the State also argued that using various means in order to achieve demographic objectives is in conformity with Israel's principles as a Jewish and democratic state. ${ }^{155}$

In Adalah, Justice Procaccia and Justice Jubran wondered whether the objective was demography or security, but they were convinced that it was security. Justice Chechin disapproved of the very mention of demographic concerns, although as Ben-Shemesh and

\footnotetext{
153 Stamka, supra note 54.

154 EC 11280/02 Central Elections Committee for the Sixteenth Knesset v Tibi (2003), IsrSC 57(4) 1; EA 2/88 BenShalom v. Central Elections Committee (1989) IsrSC43(4) 221.

155 State's Briefings in Adalah v. Minister of Interior, (16.12.2003) as cited in Adalab, supra note 107 at para 14 of Justice Procaccia's opinion.
} 
others have noted, demography featured implicitly in his opinion in the form of discussion of the status quo and the importance of preserving the society's image and culture. ${ }^{156}$ The situation changed in Galon and what was discussed by one Justice implicitly was discussed this time openly by a number of Justices.

Four Justices discussed demographic considerations at different levels of detail in Galon. The most detailed discussion was by Justice Rivilin. He referred to and quoted approvingly from a study recommending an immigration policy that takes into consideration that Israel is 'a democracy with a mission', that is, a state that is meant to embody the selfdetermination of a specific group- Jews. ${ }^{157}$ Rivilin shared the concerns of this study that Israel suffers from a negative "immigration balance" when it comes to Jewish immigration at the same time that a large number of Palestinians is seeking to unify with their spouses in Israel. He framed the demographic questions by discussing "the meaning of the Jewish state," and asking "if this meaning includes the need to promote the existence of a Jewish majority in the land." ${ }^{\text {158 }} \mathrm{He}$ then answered that it has already been decided by the Court that Israel's raisin d'être is to be a Jewish state which includes a Jewish majority. He left the question of whether the goal of a Jewish majority is enough to justify preferring the immigration (including family reunification) of one group over the other with no answer, but he implied that if this is done as part of a comprehensive normative scheme, such a question is not for the Court to decide or interfere with and the Court should defer to the legislator in issues of immigration. ${ }^{159}$

156 Yacov Ben-Shemesh, "Immigration Rights and the Demographic Consideration", online (2008) 2:1 Law\& Ethics of Human Rights 15; Aeyal Gross, "In Love with the Enemy: Justice, Truth, Integrity and Common Sense Between Israel and Utopia in the Citizenship Law Case" (in Hebrew) (2007) 23 Hamishpat 79.

157 Galon, srupra note 109 at para 14. For an English translation of the study, see, Shlomo Avineri, Liav Orgad \& Amnon Rubenstein, Managing Global Migration: A Strategy for Immigration Policy for Israel Jerusalem: The Metzilah Center, 2010) online: <http://www.metzilah.org/English/Immi_Book\%20final.pdf>.

158 Galon, srupra note 109 at para. 15 [translated by author].

${ }^{159}$ Ibid at $15-16$. 
Justice Meltzer took a more explicit approach. While he maintained that he had no intention of discussing the question of the justifications for a law that limits family reunifications in order to preserve the Jewish majority, he nevertheless provided his opinion by quoting an article by Ruth Gavison where she wrote: "[a]s a matter of principle, Palestinian families are supposed to be reunified in their state, whereas Jewish families unify in theirs."160 Meltzer praised this position as the middle point between two extremes. ${ }^{161}$ In the same vein of implicit and ambiguous discussion of the impact of demographic considerations, Justice Na'or opined that while she thinks that the objective that the Citizenship and Entry to Israel Law seeks to achieve is based on security, she is aware of the fact that the reasoning she provided in Adalab and repeated in Galon regarding the scope of the right to family life will have implications for the future immigration policy. ${ }^{162}$ That is, if there is no right to exercise the right to family life in Israel, future legislation which limits family reunification because of demographic considerations will not be declared unconstitutional because there is no violation of constitutional rights. The examination of the constitutionality of such legislation will stop at the point of stating that there is no constitutional right violated, without the need to examine the requirements of the limitation clause. Justice Levi, who was in the minority in Galon and found the law to be unconstitutional, said that he reached his conclusion because the state insisted that the legislation is motivated solely by security concerns. He then added that "if it was argued and proved otherwise, his conclusion could have been different."

\footnotetext{
160 Ruth Gavison, "The Justification for the Citizenship Law", (in Hebrew) Ynet (5 August 2003) online: <http://www.ynet.co.il/articles/0,7340,L-271.7741,00.html> [translated by author] [Gavison, "Justification"].

161 Galon, srupra note 109 at para 31.

162 Ibid at para. 4-5.

${ }^{163}$ Ibid at para 30 [emphasis the original] [translated by author].
} 
From the way the Justices discussed the question of demography and its impact on immigration and family reunification- even though this was not a question in this case- one can identify an inclination to accept that demography is a legitimate consideration in devising family reunification policies that violate the right to family life. The novelty in Galon is that the Court has signalled that demographic considerations will be seen as acceptable when they clearly, openly, and intentionally violate the individual right to family life, not just the right to equality among groups. This open adoption of demographic goals by the state, and their sanction by the Court, has important implications for the idea of the People.

\subsection{The People Between Demography and Democracy}

How does the emphasis on demography, which is inherent in the definition of the state, affect the People? How can it be reconciled with equality and democracy? While the Supreme Court did not offer a deep analysis of this question, it seems that the trend, given the sources the Justices drew on, is to follow the ideas presented by the "nationalist school" reviewed in chapter II. The leading figure who has examined this question thoroughly is Ruth Gavison. In explaining how the definition of the state as a Jewish state does not affect equality (defined as equal civil and political rights), Gavison provided two examples, one related to demography and geography (dispersion of population), and one related to demography in immigration. These examples offer insights into the nature of the People.

In the first example Gavison deals with the issue of housing and the state's (Jewish) interest in preventing territorial contiguity of Palestinian towns in Israel. Gavison argues that the state is justified in establishing new Jewish towns for the purpose of preventing territorial contiguity between Arab towns, so that these towns would not be able to secede in the future. 
In explaining this point, she says that "history proves that wherever a state has lost its demographic majority, its political hold over that specific area weakens, and the risk of confrontation and demands of independence arise, together with the risk to the security of the citizens of the parent state that live in the same area." ${ }^{164}$ In Gavison's opinion, the state's "demographic majority" is not measured by the number of citizens, but by the number of Jews, and only Jews are citizens of the "parent state". Here, the rhetoric has shifted from a distinction between citizens and "preferred" citizens who also belong to the "preferred" national group, to a distinction between citizens and aliens - a distinction that defines citizenship in ethnic/religious fashion. This view, which sees citizens as aliens, is in line with the trend that could be identified in the jurisprudence of the Supreme Court discussed earlier. It implies that in order to be part of the People there is a need for something that is beyond formal citizenship. Since the relevant group that Gavison sees as underpinning sovereignty is the "demographic majority" and not citizens as such, it would be fair to conclude that the People, in practice, is this "demographic majority". And in order to protect the sovereignty of this "demographic majority", the state is justified in limiting some patterns of growth and urban expansion in order to thwart the possibilities of territorial contiguity. The state is justified in creating "Jewish only" and "Arab only" towns based on the principle of "separate but equal. ${ }^{165}$ In addition to viewing the Palestinian citizens as aliens which raises doubts about them being part of the People, this approach raises serious questions about equality. ${ }^{160}$

\footnotetext{
164 Gavison, "Thoughts", supra note 88 at 175.

165 Ibid at 174.

160 One major flaw is it takes an ahistorical approach to the question of land and housing rights and ignores the fact that the state has expropriated more than $70 \%$ of the land owned by Palestinians, and in many cases, most of the land that is (or would be) allocated to Jewish-only towns was actually owned by Palestinians. See, Hussein Abu Hussein \& Fiona McKay, Access Denied Palestinian Land Rights in Israel (London: Zed Books, 2003) 7. Another major problem is that, while Gavison assumes a "separate but equal" approach, this kind of "equality" does not exist in reality in Israel. Statistics show that budgets allocated to Palestinian towns are fractions of the budgets and
} 
The second example is immigration policy. In addition to supporting the idea of Jewish "return", Gavison derives other relevant policies from the Jewishness of the state which are meant to maintain the Jewish majority, namely limiting the immigration of non-Jews, "provided their human rights are not breached". ${ }^{167}$ In this vein, she asserts that Palestinians living in the OP'T should be excluded from family reunification procedures, thus justifying the 2003 Citizenship and Entry to Israel Law. This position, Gavison, argues, does not constitute illegitimate discrimination because of the circumstances of the situation. She relies on a number of arguments. The first argument is the demographic argument: there is threat to the Jewish majority which should be preserved in order to maintain a stable Jewish state. ${ }^{168}$ In her opinion, a decrease in the size of the Jewish majority will lead to instability on a number of levels: a growth in the representation of the Palestinians in the legislature which will affect the ability to garner a majority to maintain the character of the state, and, on the level of principle, the inability to politically and morally maintain a nation state for one nation when there is a national minority that is about one fourth or one third of the population. ${ }^{169}$ In other words, the People should always maintain the character of the state, and laws should be enacted so that the composition of the People does not change.

Another justification Gavison provides is the lower probability of assimilation in the majority (Jewish) society. She says that a Palestinian from the OPT who is being sponsored by a spouse who is a Palestinian citizen of Israel is more likely to join the Palestinian community in

resources available for Jewish towns, and it would take many years to reach this level of separate "equality". For example, The total public expenditure on social welfare is $30 \%$ lower in the Arab sector. This gap is wider among children as the budget per child is $52.1 \%$ lower in Arab local authorities compared to Jewish local authorities. See, Katie Hesketh ed, The Inequality Report: The Palestinian Arab Minority in Israel (Haifa: Adalah- The Legal Center for Arab Minority Rights in Israel, 2011) at 22.

167 Gavison, "Thoughts", supra note 88 at 137 [translated by author].

168 Ibid at 140 .

${ }^{169}$ Gavison, "The Jewish State" supra note 86 at 63; Gavison, "Conditions for Prosperity", supra note 86 at 59. 
Israel, which is itself not integrated and "will not assimilate in the Israeli-Hebren culture and become full citizens in Israel". ${ }^{170}$ It is unclear what kind of assimilation Gavison favours especially because her approach highlights the separate cultural development of the different groups and the importance of preserving this separation. But it is insightful here that she uses "full citizens" to describe those who subscribe to the "Israeli-Hebrew" culture. This implies that those who do not belong to this culture are less-than-full citizens despite formal equal citizenship. In this context, only the majority in which immigrants are supposed to assimilate could be the People. This is Walzer's "we" who "are already members do the choosing [of the new members]", which is also "we the people". The best way to summarize Gavison's position is by quoting her article which was quoted by the Supreme Court when she said that "as a matter of principle, Palestinian families should be unified in their state, whereas Jewish families will unify in their state.",171

Gavison's treatment of the question of immigration and demography in light of the Jewish character of the state is representative of the main nationalist and liberal nationalist schools. Others, such as Rubenstein, Carmi and Gans agree in principle that demography is a legitimate consideration in devising immigration policy and that preserving a Jewish majority is a normative precept, but they disagree on certain points. ${ }^{172}$ Rubenstein agrees with all of Gavison's arguments and reasoning but falls short of endorsing a blanket prohibition of family reunification and suggests other means to regulate and control family reunification. While some of the means and criteria he suggests such as socio-economic criteria and cultural

170 Gavison, "Thoughts", supra note 88 at 147 [translated by author].

171 Gavison, "Justification", supra note 160 [emphasis added] [translated by author].

172 Rubenstein \& Orgad, supra note 88; Chaim Gans, "Nationalist Priorities and Restrictions in Immigration: The Case of Israel" (2008) 2(1) Law \& Ethics of Human Rights 12 [Gans, "Nationalist Priorities"] ; Na'ama Carmi, "Immigration Policy: Between Demographic Considerations and Preservation of Culture" (2008) 2:1 Law \& Ethics of Human Rights 22. 
integration (presumably in the Jewish society) are universal on their face, they disproportionately affect the Palestinian citizens seeking to sponsor spouses. ${ }^{173}$ In a similar vein, but in a more nuanced and cautious approach, Gans sees the preferential immigration rights in the Law of Return (within a framework of two nation states) as the only legitimate way to control demography. Gans also sees the Citizenship and Entry to Israel Law as a racist law. ${ }^{174}$

While this is the range of views on this question among Zionist writers, the Supreme Court seems to take an approach that is closer to Ruth Gavison, as explained above.

\section{Summary and Conclusions}

As discussed in chapter I, the people as a political unit that exercises sovereignty is one of the main tenets of democracy. The whole constitutional structure is usually attributed to the people. Controlling the identity of the People, and who can join the People becomes significant, especially in divided societies. A review of Israel's immigration and citizenship laws and policies demonstrate that they oscillate between granting a universal citizenship and a restrictive particularistic approach that only sees Jews as citizens. Despite this relationship which has always been in tension, the outcomes and the trends are clear. As result of the operation of the Law of Return and the Citizenship Law, what is supposed to be a universal citizenship is not universal in practice, it has several categories within it. There are also clear trends regarding the population and its composition- preserving the Jewish majority that was gained during the war in 1948.

The laws and policies on immigration and citizenship aim at increasing the number of Jewish citizens using a range of methods which include automatic citizenship, financial support

173 Rubenstein \& Orgad, supra note 88.

174 Gans, "Nationalist Priorities", surpa note 172. 
and other incentives such as allowing immigrants under the Law of Return to maintain their original citizenship. It is commonplace to criticize the Law of Return because of its strong ethno-religious discrimination. But while the Law of Return as discussed above does discriminate against the Palestinian citizens, the issue of bias in the immigration and citizenship laws and policies goes beyond that law. The immigration and citizenship laws and policies that relate to Palestinian citizens reveal a trend of narrowing eligibility to citizenship, as in the case of banning family reunification when the spouse is from the OPT, the case of second generation citizens born outside Israel, the impossibility of reacquiring lost citizenship and the tailor-made legislation on revocation of citizenship. All of these exclusionary measures, although framed in neutral language, either apply to Palestinians only or disproportionately target Palestinians.

A comparison between the law that affects the Jewish citizens most (Law of Return) and the one that affects Palestinian citizens most (Citizenship and Entry to Israel Law) best exemplifies the approach towards citizenship for both populations. The Law of Return extends rights to non-Jewish members of Jewish families to maintain the family as a unit. On the other hand, the Citizenship and Entry to Israel Law severely disrupts the lives of Palestinian families and forces them to either relocate or separate. The rights that the state is willing to recognize in the case of immigration of Jewish individuals who are not citizens yet, it is not willing to recognize for its other citizens. The Law of Return almost eliminates the discretion of the executive in that it provides very little room to deny admission to Israel or application for citizenship for individuals from Jewish backgrounds and their families. On the other hand, the Citizenship and Entry to Israel Law eliminates the discretion of the executive in that it provides almost no room 
for granting status to Palestinian spouses of Israeli citizens.

These trends have been constant since the creation of the state. The result is that, as the human rights organization Adalah has argued in its petition to the Supreme Court, in Israel there are three channels to acquiring citizenship depending on religion and ethnicity. On the top of the hierarchy is the channel for Jewish foreigners and their family members Jewish or non-Jewish) through the Law of Return. Second is the channel for non-Palestinian foreigners, and the third is for Palestinian/Arab foreigners. ${ }^{175}$

The implications of these laws and policies are immense. The state sees the interests of one group of citizens as more important and preferred over the others, rather than taking into consideration the interests of the citizenry as a whole. This approach, together with the approach adopted by the Supreme Court which compared the rights of the Palestinian citizens to the rights of permanent residents and naturalized citizens in EU countries, and the ubiquity of demographic considerations in all aspects of Israeli policies signal that formal citizenship is not a single unified category in Israel: within formal citizenship are sub-categories based on religion/ethnicity, and those sub-categories have a clear hierarchy among them. The fact that the main question in the immigration and citizenship laws is "who is a Jew" instead of "who is a citizen", and the fact that this became a constitutional question, support this assertion. This is the question that is debated most among politicians, in courts and in academia. This is one of the issues on which Governments have been formed and have collapsed; it is a question taught in constitutional law classes, and the main question which continues to preoccupy the minds and time of intellectuals, think tanks and politicians. Since this is the question, the Law of Return and not the Citizenship Law, is what defines "the polity" and the contours of citizenship 175 Amended Petition submitted by Adalah in Galon v. Minister of Interior, (2007) at para 10, online: http://adalah.org/admin/DownLoads/SPics/6425653.pdf. 
in Israel. Belonging to the political community, more than anything, is determined by belonging to the Jewish people, which is defined in a religious sense by Israeli law. The Citizenship Law in this context only plays a supporting role.

These trends in immigration and citizenship law have important implications for defining the People who exercise sovereignty. Given that all citizens are eligible to vote, one way of maintaining political power within the hands of one group is through controlling the composition of the People, or engineering the People, such that a majority that belongs to one religious/ethnic group is maintained through the operation of law. The law is devised not to benefit the citizens at large, or to provide an affirmative action scheme, but to promote the interests of the dominant group so that the minority remains politically irrelevant marginal to a point that boarders irrelevance. Still, even with the restrictive population policies used by the government, the percentage of the Palestinians among the population has increased from about $12 \%-13 \%$ to $18 \%-20 \%$ today. The growth rate within the Palestinian minority is higher than the rate among Jewish Israelis. ${ }^{176}$ Projections for the future show that Palestinians will be $25 \%$ of the population either in 2025 or $2030 .{ }^{177}$ In this context, more policies which would achieve the goal of minimizing the potential political influence of the Palestinian minority are being considered now. One of them is to allow Israeli citizens living abroad - among whom the percentage of Jews is significantly higher - to vote in the Parliamentary elections. ${ }^{178}$ This

176 In 2011, the annual growth rate for the Palestinian Arab minority was $2.4 \%$ compared to $1.7 \%$ for the Jewish population and $1.8 \%$ for the whole population. See, Statistical Abstract of Israel 2012 Jerusalem: Central Bureau of Statistics, 2013) at 94, online: <http://www.cbs.gov.il/shnaton63/st02_04.pdf $>$.

177 Arnon Sofer and Yevgenia Bisrov expect that this rate will reach around 24-25\% in 2025, while Sergio DellaPergola expects that this rate will be achieved in 2030. See, Arnon Sofer \& Yevgenia Bisrov, The State of TelAviv-A Threat to Israel, 2nd ed (Haifa: Haifa University, 2008) online http://web.hevra.haifa.ac.il/ chstrategy/images/publications/Tel_Aviv_2008.pdf; DellaPergola, supra note 138 at 236.

178 This idea is often proposed in the context of strengthening the relationship between Israel and Israelis abroad. See DellaPergola, supra note 138 at 157; see also The Jewish People Policy Institute, "Policy Recommendations for Strengthening Jewish-Israeli Identity among Children of Israelis and their Attachment to the State of Israel 
suggestion - which is currently being considered by the Government ${ }^{179}$ would lead, in terms of the engineering of the political community, to a decrease in the ability to influence the political system through electoral politics.

Taken as a whole, Israel's population policies, starting with the 1948 ethnic cleansing (and blocking of return), the restricted access to citizenship for Palestinians, the open preference for immigrants who belong to one religious/ethnic group, and the goal of preserving a Jewish majority (which means keeping the Palestinians a minority) are similar to population policies in settler-colonial states. While the formal methods may vary, the goals intended, which are to maintain domination over the native population, are the same. These policies are part of the pattern of settler states to displace and dispossess the native population (as in the case of the Palestinian refugees), to weaken and minimize political powers (as in the case of the Palestinian citizens), in order to establish the domination of the settler society. These population policies facilitate "the appropriation of the land, resources and jurisdiction... for the territorial foundation of the dominant society itself ${ }^{\prime 180}$ as Tully puts it. The policies exemplify one aspect of settler colonialism which is "the logic of elimination, a sustained institutional tendency to supplant the indigenous population which reconciles a range of historical practices that might otherwise seem distinct". ${ }^{181}$

and the Jewish Community" (22 March 2012) online: <http://ippi.org.il/news/109/58/Strengthening-JewishIsraeli-Identity-of-Israelis-Abroad/>.

179 Yair Ettinger, "Netanyau's Office Pushing Initiative to Allow Israelis Abroad to Vote in Knesset Elections", Haaretz (23 March 2012) online: <http://www.haaretz.com/print-edition/news/netanvahu-s-office-pushinginitiative-to-allow-israelis-abroad-to-vote-in-knesset-elections-1.420269>.

180 James Tully, "The Struggles of Indigenous Peoples for and of Freedom" in Duncan Ivison et al, eds, Political Theory and the Rights of Indigenous Peoples (Cambridge: Cambridge University Press, 2000) 37 at 39.

181 Patrick Wolfe, "Nation and MiscegeNation: Discursive Continuity in the Post-Mabo Era" (1994) 36 Social Analysis 93 at 96 . Again, it should be emphasized that "elimination" is not necessarily physical or violent, and it could be pursued in many ways to target the cultural identity, heritage and institutions of the indigenous population. These strategies of elimination always generate resistance by indigenous populations. 
Given this engineering, and the logic of elimination, one way to describe the immigration and citizenship policies is as a tool to limit the political influence of the Palestinian citizens by keeping their percentage in the population as low as possible. This is of course not an arbitrary policy, but is part and parcel of the prevailing understandings of the definition of the state as Jewish and democratic: the state needs to provide a measure of inclusion through citizenship to legitimate its existence, but at the same time it emphasizes the Jewish character and the promotion of Jewish majority as a normative goal to the point that it makes formal equal citizenship subordinate to the Jewish character. All of the facets of this policy and the legislation related to it have been sanctioned by the Supreme Court. But the outcome of the oscillation between these two poles is not neutral, for the Jewish definition is given more weight, and the final result is that the whole system functions in a way to keep the numbers of the Palestinians as low as possible and thus exclude them from centres of power and influence. These laws and policies, therefore, are one of the ways of distancing the Palestinian citizens from the People that exercises sovereignty and constituent power.

This approach is complemented by the various measures, embedded in Israeli constitutional law, that inhibit the participation of the Palestinian citizens in exercising political power. These measures, which are all manifestations of Israel's Jewish definition, will be discussed in the next chapter. 


\section{Chapter V}

\section{Drawing the Red Lines: Political Representation and the Jewish and Democratic Definition}

\section{Introduction}

In a parliamentary system, the parliament is the central body of governance. While its tasks and powers may vary from one state to another, two main functions are vital for the parliamentary system. The first function is the enactment of legislation, which allows and facilitates the task of governing. The second function is related to choosing, supporting and overseeing the executive: the executive branch is usually drawn from and accountable to the parliament. The head of the executive branch can only govern as long as he/she enjoys the confidence of the parliament. Similarly, in order to govern effectively and be able to implement policies, the executive needs to enjoy the support of a majority of members of parliament in order to enact legislation. In a parliamentary system, therefore, elections for the parliament, as former Chief Justice Aharon Barak asserts, could be seen as one of the ways to express the sovereignty of the people: through elections, the People choose their representatives. ${ }^{1}$ To borrow from the Basic Law of the Federal Republic of Germany, "[a]ll state authority is derived from the people. It shall be exercised by the people through elections and other votes and through specific legislative, executive and judicial bodies."2

The idea of representation is central to parliamentary systems and governing in general. It is, as Martin Loughlin explains, pivotal "in fashioning both the relationship between

${ }^{1}$ See EC 11280/02 Central Elections Committee for the Sixteenth Knesset v Tibi (2003), IsrSC 57(4) 1 at 23 (in Hebrew) [Tibi].

${ }^{2}$ Article 20(2)) of the Basic Law of the Federal Republic of Germany. 
governors and governed and the way in which government acquires an 'artificial, public status", 3 for, as Loughlin adds, "[i]t is only through representation that those exercising governmental power are given certain responsibilities; similarly, it is only through

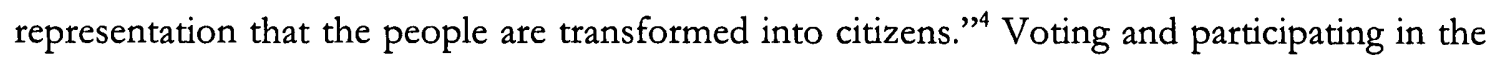
elections also mean, as the German Federal Constitutional Court put it, "the right to participate in the legitimation of state power and to influence its exercise.",5

Given the importance of representation and elections to the idea of the people, this chapter will explore the role that the Jewish and democratic definition of the Israeli state plays in the electoral process and the parliamentary work of the elected representatives. While the universal adult franchise and the right to vote - features that define and identify democratic systems - are guaranteed in Israel, there are significant limitations on the right to participate in elections that are related to the definition of the state. These limitations have an impact on representation and raise questions about the relationship between the government and Palestinian citizens. The examination will begin with a discussion of the landmark Yerdor case of 1965 and the emergence of the rule, which was first introduced in that ruling, authorizing the restriction of the right to participate in elections. ${ }^{6}$ The rule became a foundational doctrine of Israeli constitutional law. This doctrine has evolved and found clearer and more explicit expression in section 7A of Basic Law: The Knesset. I will consider the development of this section and the way it has been interpreted by the Supreme Court. I will also examine the impact of the Jewish and democratic definition on legislation that affects the electoral process

${ }^{3}$ Martin Loughlin, The Idea of Public Law (Oxford: Oxford University Press, 2003) at 70.

${ }^{4}$ Ibid.

${ }^{5}$ Maastricht Treaty Case, 89 BV erfGE 155 (1993) cited in Donald P. Kommers \& Russel A. Miller, The Constitutional Jurisprudence of the Federal Republic of Germany, 3d ed (Durham: Duke University Press, 2012) 239.

${ }^{6}$ EA 1/65 Yerdor $v$ Chairman of the Central Elections Committee for the Sixth Knesset (1965), IsrSC 19(3) 365 (in Hebrew). 
and political participation such as the Parties Law-1992. The way the definition affects the rights of the elected Members of Knesset (MK) will also be discussed. The chapter will conclude by providing a summary of the impact of the definition on representation and the conception of the People in the constitutional order.

\section{The Evolution of a System of Exclusion: From Yerdor to Section 7A of Basic Law: The Knesset}

With the creation of Israel, the founders adopted a Westminster parliamentary model based on proportional representation. The Law and Administration Ordinance-1948, and later the Transition Law-1949, established the parliamentary system, and the Elections for the Constituent Assembly Ordinance-1948 adopted the proportional representation system. These arrangements continued the traditions of the governing institutions of the organized pre-state Jewish community (Yishuv) which also followed those models. ${ }^{7}$ Today, the constitutional arrangements establishing and governing the executive and legislative branch are found in Basic Law: The Government and Basic Law: The Knesset respectively. Section 1 of Basic Law: The Government prescribes that "[t]he Government is the executive authority of the State" while section 3 provides that " $[t]$ he Government holds office by virtue of the confidence of the Knesset." The Knesset is the representative body of the state. Section 1 of Basic Law: The Knesset provides that "[ $t]$ he Knesset is the house of representatives of the State."

Elections in Israel are governed by a number of statutes. Section 4 of Basic Law: The Knesset provides the most fundamental principles that guide the electoral process. Elections, according to section 4, should be "general, national, direct, equal, secret and proportional".

\footnotetext{
${ }^{7}$ Peter Medding, The Founding of the Israeli Democracy $1948-1967$ (New York: Oxford University Press, 1990 ) at 31.
} 
The principles enshrined in this section are so central to the electoral process that the section gained special protection: it can be amended only by a majority of the members of the Knesset, as opposed to a majority of present and voting members which is the norm for adopting and amending legislation, even basic laws. Constitutional guarantees also protect the integrity of the electoral process. The right to vote and the right to be elected to the Knesset are both protected, with some exceptions, by Basic Law: The Knesset. ${ }^{8}$ Elections have been periodically conducted since 1949 , and the results have always been accepted by all parties involved. Power has always been transferred peacefully.

While these rights, which are critical for any democratic system, are guaranteed by Basic Law: The Knesset, and the exceptions for them are fairly reasonable, the basic law contains another provision that presents a significant challenge to democratic principles. Section 7A bans the participation in elections of individuals and parties if their goals and actions, expressly or by implication include "negation of the existence of the State of Israel as a Jewish and democratic state" [s.7A(1)], or "incitement to racism" [s.7A(2)], or "support for armed struggle by a hostile state or a terrorist organization against the State of Israel" [s.7A(3)].'

\footnotetext{
${ }^{8}$ Section 5 of Basic Law: The Knesset provides that:

Every Israel national of or over the age of eighteen years shall have the right to vote in elections to the Knesset unless a court has deprived him of that right by virtue of any Law; the Elections Law shall determine the time at which a person shall be considered to be eighteen years of age for the purpose of the exercise of the right to vote in elections to the Knesset.

Section 6(a) of the same Basic Law provide that:

Every Israel national who on the day of the submission of a candidates list containing his name is twenty-one years of age or over shall have the right to be elected to the Knesset, unless a court has deprived him of that right by virtue of the law or he has been sentenced, by a final verdict, to actual imprisonment for a term of over three months and on the day of submission of the list of candidates seven years have not passed since the day he concluded serving his term of imprisonment, unless the chairman of the Central Elections Committee has determined that the crime of which he has been convicted, in accordance with the circumstances, does not bear moral turpitude.

Translated by the Knesset, online:
} <http://www.knesset.gov.il/elections17/eng/law/BasicLawKnesset eng.htm>. 
While these three grounds for disqualifying individuals and parties from participation may at first glance appear reasonable, a closer examination of their history, political impact, and the way they are integrated in the broader constitutional order provides a different picture. This part of this chapter will trace the evolution of this section and its judicial interpretation focusing on the interpretation and impact of the Jewish and democratic definition.

\subsection{Political Representation of the Palestinian Citizens in Israel Post-1948}

Section 7A of Basic Law: The Knesset, especially subsection (a)(1) which refers to the Jewish and democratic definition, is the latest incarnation of the rule that was first introduced in the Yerdor case, which was discussed briefly in chapter III. As mentioned there, the Yerdor decision concerned an appeal to the Supreme Court of the decision of the Central Elections Committee (CEC) to ban "the Socialist List" from participating in the 1965 Knesset elections. In order to better understand the context of this decision and ban, some background information should be provided.

The Palestinian Nakba - the displacement of the majority of the Palestinians from their homes in the areas that became Israel - had a significant impact on those Palestinians who did not become refugees. The implications went beyond the humanitarian factors: the flight of the majority of the Palestinians from the areas that came under Israeli control, including the major urban areas of Jaffa, Haifa, Acre and Jerusalem, also meant the demise of

(a) A candidates list shall not participate in elections to the Knesset, and a person shall not be a candidate for election to the Knesset, if the goals or actions of the list or the actions of the person, expressly or by implication, include one of the following:

(1) negation of the existence of the State of Israel as a Jewish and democratic state;

(2) incitement to racism;

(3) support for armed struggle by a hostile state or a terrorist organization against the State of Israel.

(a1) For the purpose of this section, a candidate who has spent time in an enemy country in the seven years prior to the date of submitting the candidate's list, shall be seen as someone whose actions are considered support for armed struggle against the State of Israel, unless it was proved otherwise.

Translated by the Knesset, online: <http://www.knesset.gov.il/elections17/eng/law/BasicLawKnesset eng.htm>. 
those places as sites of Palestinian political activity. More importantly, the Palestinian political elite that led and navigated the political process was also displaced. The Palestinians in Israel found themselves with no political leadership. Two main groups tried to fill this political vacuum. The first was the Zionist parties, mainly the ruling $M A P A I$ party (the parent of the Labour Party), and the left leaning $M A P A M . M A P A I$ saw in the Palestinians a reservoir of votes that it could tap into during elections either directly, or through electoral lists that are related to the party but are not part of it. In essence it chose the representatives of those lists that were supposed to be the representatives of the Palestinians (or the Arabs of Israel as they are called officially). Those representatives were usually individuals who had strong relations with Zionist groups before 1948 and whose loyalty to the regime - as opposed to the electors - was not in doubt. $M A P A I$ and the satellite lists garnered a significant percentage of the vote mainly because of the control of the Military Administration over most aspects of life in the Arab towns and villages. ${ }^{10}$ The $M A P A I$-dominated Military Administration used its strong control and a wide range of methods to incentivize or coerce a vote in favor of $M A P A I$ and its satellite electoral lists. ${ }^{11}$

The second group that provided a platform for political activism was the Israeli Communist Party whose membership included both Jews and Palestinians. It was a continuation of the Palestine Communist Party which was a predominantly Jewish party after the Palestinian Arab communists -who were opposed to the idea of partition - left it in 1943

\footnotetext{
${ }^{10}$ From 1948 until the end of 1966, the Palestinians in Israel were subject to military rule known as the Military Administration. Army personnel administered almost all aspects of life. Almost all activities including leaving the towns and villages required special permits. See Sabri Jiryis, The Arabs in Israel (New York: Monthly Review Press, 1976) Diryis, "Arabs in Israel”].

11 Ibid; Ian Lustick, Arabs in the Jewish State: Israel's Control of a National Minority (Austin, TX: University of Texas Press, 1980); Ilan Pappe, The Forgotten Palestinians: A History of the Palestinians in Israel (New Heaven, CT: Yale university Press, 2011) at 69.
} 
to form the League for National Liberation. After 1948, the Arab communists who stayed in the areas that became Israel joined the Israeli Communist Party. ${ }^{12}$ The Party, though committed to internationalism and Marxism, was very much part of the Jewish/Zionist political order. One of its members, Meyer Wilner, was one of the signatories of the Declaration of Independence. It was represented on the Temporary State Council (the legislative body of the state from May 1948 until the first elections in January 1949) and the Temporary Government (1948-1949), and its members fought in the 1948 war. The presence of the Palestinian members (one of whom, Tawfiq Toubi, was elected to the Knesset in 1949), and the party's policy of opposing the Military Administration and supporting the return of the Palestinian refugees made the Party the only possible political home for the Palestinians in Israel. The Communist Party also emerged as the only political party that tried to defend the Palestinian citizens through the Knesset. Its members of the Knesset used their freedom of movement (which was not available for Palestinians whose movement was curtailed by the Military Administration and the Emergency Regulations) to expose governmental policies and sometimes atrocities such as the Kufr Kassem massacre of $1956 .{ }^{13}$

The Communist Party planned further expansion among the Palestinian community, and in the late 1950 s formed an alliance with figures who were more inclined toward Arab nationalism rather than communism. This alliance was called "The Arab Front", but was later changed to the "Popular Front" since the authorities refused to register it because of what they saw as a suspicious name. ${ }^{14}$ In 1959 , tensions between the communists and the nationalists resulted in the withdrawal of the nationalists who formed a new political group

\footnotetext{
12 Dunia Habib Nahas, The Israeli Communist Party (London: Portico Publications, 1976) at 24-25.

13 Pappe, supra note 11.

14 Jiryis, "Arabs in Israel", supra note 10 at 186-187.
} 
called $A l-A r d$, which means "the land" in Arabic. $A l-A r d$ did not aim to participate in electoral politics. In fact it called for a boycott of the elections of $1959 .{ }^{15}$ Its main aim was to form a political movement that would organize the Palestinians in Israel on a national basis. While members of the group were able to organize some meetings and protests, most of their energy was spent trying to resist legal obstacles that the authorities mounted. Some of its members were prosecuted for publishing a newspaper without a permit. ${ }^{16} \mathrm{Al}-\mathrm{Ard}$ also tried to legally challenge - without much success - the Government's refusal to grant a newspaper permit. Having failed to obtain a permit, they tried to incorporate as a commercial company; an attempt that was successful after the Supreme Court intervened twice. ${ }^{17}$ The company's application for a newspaper permit was denied. ${ }^{18}$ At that time, the leaders of the group decided to register a not-for-profit association (an Ottoman Association, as it was called then). Most political parties were incorporated in that format, and registration was relatively easy. According to the 1909 Ottoman Associations Law, incorporation takes place when a notice is served by the founders, together with articles of association. This, it was thought, would give the Al-Ard activists more flexibility to organize without having a newspaper. At that time, and especially after $A l$-Ard sent a complaint to the United Nations explaining the conditions of the Palestinians in Israel, the Israeli authorities decided to put an end to the phenomenon: the

${ }^{15}$ Ron Harris, "Jewish Democracy and Arab Politics: Al-Ard Movement at the Supreme Court" (in Hebrew) (2001) 10 Plileem 107 at 147.

${ }^{16}$ CrimA 228/60 Qabwaji v. The Attomey General (1960), IsrSC 14(3) 1929 (in Hebrew).

17 HCJ 241/60 Kardoush v Company Registrar (1961), IsrSC 15(2) 1151. Affirmed in FH 16/61 Company Registrar v Kardoush (1962), IsrSC 16(2) 1209 (in Hebrew).

${ }^{18} \mathrm{HCJ}$ 39/64 Al Ard Company Ltd. $\nu$ Officer in Charge of the Northern District (1964), IsrSC 18(2) 340 (in Hebrew). 
request to register the association was denied, and the denial was confirmed by the Supreme Court. $^{19}$

\subsection{The Yerdor Case and the Triumph of Zionism over Formalism}

It is important at this stage to discuss some details of the Supreme Court decision upholding the ban on registration as an Ottoman association (Jiryis). The discussion in Yerdor could not be understood without discussing Jiryis - the decision in which the Supreme Court engaged the political ideas of $A l-A r d$. In Jiryis, $A l-A r d$ was denied registration because its goals, as listed in the application, were seen as illegal. The goals included full equality and social justice in Israel, seeking peace in the Middle East and the world, and support for progressive movements in the world and opposition to imperialism. But the two goals there were discussed at length by the Court were

c. Finding a just solution for the Palestinian problem -and seeing it as an indivisible unitaccording to the will of the Palestinian Arab people, [the solution] should address interests and ambitions [of the Palestinian Arab people], restitute its political existence, and secure its full and legal rights, and see it as the foremost holder of the right to determine its destiny by itself in the framework of the supreme ambitions of the Arab nation.

d. Supporting liberation movements, unity and socialism in the Arab World, in all legal ways, and seeing it as the determining force in the Arab World which requires Israel to act towards in a positive manner. ${ }^{20}$

The Court viewed these two articles as a threat to the sovereignty and territorial integrity of the state. The judges mostly focused on what the articles did not include. They highlighted the fact that $A l-A r d$ did not qualify the "ambitions of the Arab nation" and did not balance that statement with the will of the Jewish people. They also noted that the articles did not include

${ }^{19} \mathrm{HCJ}$ 253/64 Jizyis v Office in Charge of the Northern District (1964), IsrSC 18(4) 673 [jiryis]; Jiryis, "Arabs in Israel", supra note 10 at $190-192$.

${ }^{20}$ Jiryis, ibid at 675 [translated by author]. 
any recognition of Israel as a sovereign state or any of the goals the state has set for itself. "The negation of the sovereignty of the State of Israel was not laid out in the articles of association, but it is implicit and is warranted", Justice Witkon explained. ${ }^{21}$ The Justices saw the fact that neither Israel nor the Jewish people were mentioned as denial of their existence. "The Jewish element does not exist in this view." Justice Witkon asked regarding the program: "who could believe that it could be implemented by way of peace and persuasion, and that it does not mean underground activities and hostility at the end."23 Justice Landau, in a concurring opinion, also linked the goals of $A l-A r d$ to violence. In his view, the proposed goals of the association could only be achieved by way of imposing the will of one group over the other using violence. Both judges found support for their position in radio broadcasts and newspaper articles in the Jordanian and Egyptian media which encouraged the activities of $A l$ Ard. The conclusion was that it is impossible "to demand from any regime, in the name of freedom of association, to give its stamp of approval for the formation of a fifth column within the borders of its state." ${ }^{24}$ Soon after this decision, the $A l$ - $A r d$ movement was declared an illegal group and the assets of the company were seized and many of its members were arrested. $^{25}$

Having exhausted all avenues for political organizing, members of $A l$-Ard decided to make one last attempt, and this time they decided to participate in the elections. The logic behind this shift was their hope that having a representative in the Knesset would provide the group with some political room for maneuver. At the same time, the immunity that the office

\footnotetext{
21 Ibid at 679 [translated by author].

22 Ibid at 677 [translated by author].

23 Ibid at 677 [translated by author].

${ }^{24}$ Ibid at 681 [translated by author].

${ }^{25}$ Jiryis, "Arabs in Israel", supra note 10 at 192.
} 
provides would give the member some protection and flexibility. Taking advantage of the easy technical requirements for participation in the elections for the Knesset, members of $A l-A r d$ decided to run as the "Socialist List". The announcement of their plans was met with a strong reaction by the authorities- the leadership was banished to peripheral Jewish towns and many activists were served with orders restricting their residence and movement. ${ }^{26}$ It should be pointed out that despite the harassment $A l-A r d$ members endured, none of its members was prosecuted or found guilty of any criminal offence, except for publishing a paper without a permit.

The attempts to benefit from the relaxed legal requirements were not successful. Following the law, Al-Ard members learned, does not necessarily bestow protection, for the law does not always end up being what it seems to be on first sight. This they learned when the Central Elections Committee (CEC) banned the Socialist List from participating in the elections and the Supreme Court, in the Yerdor ruling of 1965, refused to reverse the ban. What made the Yerdor case significant and interesting from a political and legal point of view was the lack of a statutory provision authorizing the CEC or the Court to ban participation. Although the role of the CEC was technical, ${ }^{27}$ with the support of its Chairman - who by law has to be a Supreme Court judge - it went ahead and disqualified the Socialist List on the grounds that "it is an illegal association, because its initiators negate the [territorial] integrity of the State of Israel and its existence." 28 The appeal to the Supreme Court was decided by a majority of two to one. The minority judge, Justice Haim Cohen, loyal to the principle of the

\footnotetext{
${ }^{26}$ Ibid at 194.

27 The CEC is composed of representatives of the political parties who are represented in the outgoing Parliament and is chaired by a Supreme Court judge. Given its composition, it is seen as a political body and not as a judicial or an administrative body.

${ }^{28}$ Yerdor, supra note 6 at 369 [translated by author].
} 
rule of law, ruled that in the absence of a statutory provision, "neither logic, nor necessity, love of one's homeland, or any other consideration, whatever it is, justify taking law into the hands and the denial of the right of the other." ${ }^{29}$ This reflected the formalist line that characterized the Court's approach in the first two decades of its existence.

The other two judges upheld the decision of the CEC and confirmed the ban, but each of them provided different - though closely related - grounds and justifications for his decision. Then Chief Justice Agranat ruled that in order to determine the scope of the authority of the CEC, some constitutional "givens" or "facts" should be taken into consideration. Those include the fact that the state was created as a Jewish state based on the right to self-determination of the Jewish people, and that this state is meant to be eternal. The eternality of the state is a constitutional fact that cannot be questioned by the authorities of the state, and should be taken into account in the process of interpretation, especially interpretation of constitutional laws. ${ }^{30}$ Since the Knesset, together with the government, is the body that is responsible for securing the existence of the state, membership from a group that aims at eliminating this sovereignty in these bodies is not possible. ${ }^{31}$ To justify his position, and the apparent contradiction with democracy, Chief Justice Agranat mentioned the Weimar Republic and the American Civil War as examples of how democracy could be subverted by groups who rise to power democratically. ${ }^{32}$ Justice Sussman, the other member of the two judge majority, agreed with this assessment but added, resorting to natural law, that "[i]n the same way a person cannot agree to be killed, the state does not have to agree to be eliminated

${ }^{29}$ Ibid at 379 [translated by author].

30 Ibid at 386.

31 Ibid at 387 .

32 Ibid at 388. 
and erased from the map." ${ }^{33} \mathrm{He}$ added, invoking the principle of "defensive democracy", that "any authority of the state should not function as a device in the hands of somebody who aims at the elimination of the state, and does not, maybe, have any other goal." ${ }^{\text {34 }}$

Despite numerous attempts, which combined a sophisticated blend of local mobilization, litigation and international advocacy, Al-Ard's efforts to become a political force were frustrated by the intimidation of the authorities. Al-Ard's major contribution, as Ron Harris observes, was to the development of the Israeli legal system. ${ }^{35}$ The movement resorted to legal action six times over the span of five years, and two of those actions resulted in precedents regarding freedom of the press, freedom of association and the right to participate in elections.

\subsection{The Yerdor Case as Foundational Principle in Israeli Constitutional Law.}

The short 1965 decision of the Supreme Court in Yerdor upholding the exclusion from electoral politics of $A l-A r d$ 's Socialist List quickly became one of the most important cases in the history of Israeli law, not only because the different opinions illustrate a debate between legal positivism and natural law, but also because in this direct confrontation between Zionism and the classic liberal conception of the rule of law, Zionism emerged as the winner. This preference for Zionism, although couched as defence of democracy and defensive democracy, led some to argue the Supreme Court introduced a judge-made "supra-constitution" and

33 Ibid at 390 [translated by author].

${ }^{34}$ Ibid [translated by author]. It should be noted that most commentators see the position of the majority as one position. Barak Medina suggests that they are two different positions. He argues that for Agranat it is enough that a party is ideologically opposed to Israel's Jewish character to bring it within the scope of the prohibition. Sussman's approach, on the other hand, according to Medina, requires the additional condition of supporting violent means to achieve the political goals. See Barak Medina, "Forty Years for the Yerdor Ruling: Rule of Law, Law of Nature, and the Limits of the Legitimate Discourse in the Jewish and Democratic State" (in Hebrew) (2006) 22 Mehkari Mishpat 327 at 345.

${ }^{35}$ Harris, supra note 15. 
created a feeling of uncertainty. ${ }^{36}$ On the other hand, Raef Zreik provides a more historically informed socio-legal explanation. Zreik argues that the Court's resort to natural law was in part because

[T] he absence of a positive law granting the Election Committee authority of this nature shows that the need for such a law had not even occurred to anyone, testifying to the mindset of the architects of an Israeli legal system for whom such legislation would have been redundant, so deeply internalized was the absolute Jewishness of the state. Beyond that, what the incident plainly showed is that if ever a Palestinian citizen were to decide to take the promise of citizenship seriously, he or she would find the Jewish state fully mobilized to block the way. ${ }^{37}$

What role does the People play in Yerdor? On the one hand we can see the people in Agranat's emphasis on Jewish self-determination as the basis of the state. Agranat, however, was also well aware of the principles that designate the People as the sovereign, but he used the Weimar Republic and the American Civil War as cautionary tales, and thus compared $A l$ Ard and its Socialist List and by extension the Palestinian narrative, to the Nazis and the Confederate states. ${ }^{38}$ The sovereignty of the People has its limits, and it stops where Nazism, slavery and, (by way of comparison) Palestinian nationalism start. The sovereign is the People minus those who accept that Palestinians have equal rights and are equal political actors. The latter group should be kept out of the political system and should not be able to take part in exercising "sovereignty", not even on a formal level.

The rule used in Yerdor was vague. It is clear that the right to political participation is limited if a political association does not recognize basic elements of the state or if the candidates are seen as a threat to the state. It was also obvious that political organizing of the

\footnotetext{
${ }^{36}$ Shlomo Guberman, "Israel's Supra-Constitution" (October, 1967) 2:4 Israel Law Review 455 at 460.

${ }^{37}$ Raef Zreik, "Why the Jewish State Now?" (2011) 40:3 Journal of Palestine Studies 23 at 28.

38 Yerdor, supra note 6 at 387 (Agranat says at the end of his opinion "And finally: It has not been lost on me that political science theory teaches that in a democratic state the sovereign is the people itself..." [translated by author].)
} 
Palestinians along national lines was seen as treacherous, or suspicious at best. A party organized for this purpose cannot participate in electoral politics. It is unclear, however, where the line for prohibition is drawn. Is it in not recognizing the state's existence? Not recognizing its Jewish character and the Law of Return? The answers to these questions became clearer in subsequent rulings of the Supreme Court.

\section{The Introduction of Section 7A of Basic Law: the Knesset and the Interpretation of "Jewish and Democratic" State}

The vagueness of the Yerdor rule was partially eliminated in 1984 when the Supreme Court discussed, for the second time, the issue of banning participation in the elections. ${ }^{39}$ The CEC banned two lists in 1984: the Progressive List which was a joint Jewish-Arab list led by Mohammad Mia'ri who was a former member of $A l-A r d$, and Kach, an extreme right-wing party led by Meir Kahane which presented an overtly racist platform. ${ }^{40}$ In its decision on the right of the two parties to participate in the elections, the Supreme Court applied the Yerdor rule in a manner that restricted its scope and its applicability to situations where the party totally negates the existence of the state. Chief Justice Shamgar and Justice Barak also added the requirement that there should be a reasonable probability that the objectives of the list would be achieved. The Court concluded that there was no evidence that the Progressive List was the continuation of $A l-A r d$, and for Kach, the Court ruled that the CEC lacked the statutory power to ban the list because of its racist political programme. Three justices in this case recommended that the whole issue of disqualifying candidates and lists from participating

\footnotetext{
39 EA 2/84 Neiman v. Chairman of the Central Elections Committee for the Eleventh Knesset (1985), IsrSC 39 (2) 225 (in Hebrew) [Neiman]. It should be mentioned that a petition was submitted in 1981 to ban the participation of Kach in the 1981 elections. The petition was rejected on procedural grounds without discussing the merits. See HCJ 344/81 Negbi v Central Elections Committee for the Tenth Knesset (1981), IsrSC 35(4) 837 (in Hebrew).

${ }^{40}$ Kahane's political positions were discussed in chapter 3.
} 
in the elections should be regulated through legislation rather than leaving it to the Court to decide with no guidance from the Knesset.

The Knesset heeded the recommendation, and in 1985 it enacted section 7A of Basic Law: The Knesset which gave the CEC the power to ban the participation of any list if its goals and actions, expressly or by implication, include "the negation of the existence of the State of Israel as the state of the Jewish people", the negation of its democratic character, and incitement to racism. In essence, it clarified the Yerdor rule by explicitly including the characterization of the state as the state of the Jewish people as part of the grounds for banning a party's participation in the national elections. Until then this was only implicit in "the negation of the existence of the state" and based on the reasoning of Chief Justice Agranat in Yerdor. The section also added negation of democracy and incitement to racism as grounds for excluding a group from the electoral process as a response to the Court's refusal to ban the participation of Kach in 1984. Section 7A was amended in 2002 combining the first two grounds into one ("the negation of the existence of Israel as a Jewish and democratic state"), ${ }^{41}$ and adding new grounds especially tailored for Palestinian candidates - supporting armed conflict by an enemy state or a terror organization. In 2008 the Knesset amended the section and added a presumption that a candidate who, in the seven years prior to the election, has spent time in an enemy country, would be seen as supporting armed struggle against Israel unless proven otherwise. The prohibitions in section 7A are not limited to the elections for the Knesset only. In 1998, the Knesset amended the Local Authorities Law (Elections)-1965, and

41 The use of this phrase was meant to bring it in line with the basic laws that were enacted in the early 1990 s that use the same language. 
added similar prohibitions for elections for local and city councils. ${ }^{42}$ Essentially, the prohibition was extended to all levels of government, national and local. ${ }^{43}$

\subsection{Ben Sbalom v. CEC}

The scope of section 7A was first tested in the 1988 elections. The CEC rejected a request to ban the participation of the Progressive List and at the same time banned the participation of Kach. Kach appealed the decision, and in the case of the Progressive List, members of the CEC appealed the CEC's decision and demanded its reversal. In Neiman, decided in 1988, the Supreme Court unanimously rejected Kach's appeal and confirmed the ban. ${ }^{44}$ Acknowledging that the section restricts a basic right, the Court ruled that the interpretation should be "specific, narrow and restricted" and the section should only be used in the "most extreme cases". 45 The Court also ruled that a party's goals or actions that could bring it within the ambit of section $7 \mathrm{~A}$ have to be part of its dominant characteristics and the central ambitions that it is trying to achieve. The latter two should be proved using "clear, unequivocal, and convincing" evidence. ${ }^{46}$ The Neiman ruling thus established very strict

${ }^{42}$ Section 39A of the Local Authorities Law (Elections)-1965 provides:

A candidates list shall not participate in elections for a local authority according to this law, if the goals or actions of the list, expressly or by implication, include one of the following:

(1) negation of the existence of the State of Israel as the state of the Jewish people;

(2) negation of the democratic character of the state;

(3) incitement to racism; [translated by author].

${ }^{43}$ No candidates were ever disqualified on the grounds that they negate the Jewish character of the state. This could be because of the nature of the local elections in Israel, which tend to be very localized, especially in Palestinian towns and villages where the competition does not necessarily reflect political rivalries, by local and family-based rivalries. There was one unsuccessful attempt to use it in 2008, which failed on technical grounds. HCJ 9822/08 Movement for the Quality of Governance in Israel v Elections Administrator, Municipality of Sakbneen (2008), (unpublished). On the other hand a list was once disqualified because its programme included racist statements against Arabs. See CLA 6709/98 Attormey General v Moledet, Gesher, Tsomet List for the Local Authority Elections, Upper Nazareth (1999), IsrSC 53(1), 351 (in Hebrew).

${ }^{44}$ EA 1/88 Neiman $v$ Chairman of the Central Elections Committee for the Twelfth Knesset (1988), IsrSC 42(4) 177 (in Hebrw) [Neiman].

45 Ibid at 187.

46 Ibid at 188. 
standards for using section $7 \mathrm{~A}$. These interpretative and evidentiary standards would prove to be consequential for the Progressive List.

The appeal regarding the Progressive List (Ben Shalom v. CEC) was rejected by the Supreme Court, also in 1988, in a split decision (3 to 2) allowing it to participate in the elections. The main point of disagreement between the majority and minority judges was whether the evidence adduced was sufficient to bring the Progressive List within the scope of section $7 \mathrm{~A} .{ }^{47}$ Compared to the majority, the minority supported a broader interpretation of the phrase "state of the Jewish people" and what constitutes its negation, although the gap between the two sides was not very significant and it seems that they agreed on more points than they disagreed on. The majority decided that the application of section 7A is not limited to the circumstances of the Yerdor case and thus they clarified that section 7A broadened the scope of the prohibition. ${ }^{48}$ Of the majority judges (then Chief Justice Meir Shamgar, and Justices Shlomo Levine, and Moshe Bejski), only Shlomo Levine provided an interpretation of the phrase "state of the Jewish people" (with which Bejski concurred). Shlomo Levine's opinion established a minimal definition of the phrase. The minimal definition meant that the state should have a Jewish majority, that Jews should be given preference in "returning to their land", and it should include a recognition of the existence of a bilateral relationship between the state and Jews worldwide. A party whose central and dominant goal is to terminate any of those elements falls within the scope of section 7A. While he found that the evidence that the Progressive List seeks to terminate the Jewish nature of the state was weak, he said that the

${ }^{47}$ EA 2/88 Ben Shalom v Chairman of the Central Elections Committee for the Twelfth Knesset (1989), IsrSC 43(4) 221 (in Hebrew) [Ben Shalom].

48 Ibid at 248. 
party's objectives are close enough, and that his decision to permit their participation was made "with a lot of hesitation.",49

The minority judges, Menchem Elon and Dov Levine, provided a similar but more elaborate interpretation. The minority emphasized the Law of Return and the ideals related to Israel being the Jewish national home as enshrined in the Declaration of Independence. The right of Jews to immigrate to Israel, Justice Elon elaborated, was not created by the Law of Return. The latter just declared it. The right, he forcefully asserted, "created and built the State of Israel." 50 The Law of Return, therefore, is the "constitutional foundation stone of the essence of the state as the state of the Jewish people." ${ }^{51}$ While this is the essence of the Jewish state, the Jewish state upholds the equality of rights and duties of all its citizens, but this equality "does not change the principle that the State of Israel is the state of the Jewish people, and the Jewish people only."52 Justice Elon explained that although all citizens in the state enjoy equal rights with no discrimination, in the case of nationality/nationalism, "the State of Israel is a Jewish state and not a Jewish-Arab state, and is the state of the Jewish people, not only from a cultural and spiritual perspective, but also from a legal and normative perspective...".53 Similarly, Justice Dov Levine had reservations about the idea that Israel is a state that belongs to all its citizens in the same way. This approach, Justice Dov Levine explained, is problematic because it does not give any preference to the Jewish people in terms of the essence of the state. $^{54}$

\footnotetext{
49 Ibid at 251 [translated by author].

50 Ibid at 263 [emphasis in original] [translated by author].

51 Ibid at 272 [translated by author].

52 Ibid [translated by author].

${ }^{53}$ Ibid at 276 [translated by author].

54 Ibid at 242.
} 
The majority and minority opinions in Ben Shalom have much in common. Both highlight the importance of the Law of Return, and the importance of the relationship between the state and the Jewish people as a global collective, not just the citizens of the state. The difference is the scope of this relationship: while the majority (mainly Shlomo Levine and Bejski) focused on three specific elements, the minority gave elements related to Jewish immigration and the state's relationship with the Jewish diaspora a more elaborate interpretation, and took some of the assertions inherent in the definition to their logical conclusions, a step that the majority did not do. For example, the minority took the discussion on nationality a step further, and highlighted that the Law of Return establishes one dominant national group in Israel as a normative matter, and excludes Palestinians or Arabs as an equal group that seeks recognition in the state. Recognition was only bestowed on individuals who have equal individual rights and duties. The majority on the other hand stopped at the level of highlighting manifestations of Jewish nationalism. One can identify that the disagreement was not on the issue of evidence only, it was also on the breadth and depth of the interpretation of the phrase "Israel as the state of the Jewish people" which has implications for the question of evidence: the broader and deeper the interpretation is, the easier it is to find evidence negating it.

The Ben Shalom case, when taken in conjunction with Neiman, could be seen as a classic display of how Israel's Jewish definition comes into play in defining the outer limits of acceptable political activities and electoral politics. On one extreme, the Court upheld the exclusion of Kahane's ultra-nationalist approach because of its racist and anti-democratic nature. On the other extreme, the democratic approach represented by the idea of the state of all its citizens was viewed with suspicion, and was seen as a questionable if not an extreme 
perspective that could only be allowed to be advanced by parties or candidates in electoral politics reluctantly and "with a lot of hesitation". In terms of the categories of thinking about the "Jewish and democratic" definition of the state outlined in chapter II, the majority opinion in Ben Sbalom represents the pragmatic approach and to a lesser extent the liberal nationalist approach. It sets the red line at the Law of Return. The minority judges can be seen as expressing the nationalist approach: they focus on the question of nationalism and the right to self-determination in a more exclusionary manner. ${ }^{55}$ Ben Shalom was in essence a debate between these approaches. This debate developed further in later Court decisions.

\subsection{The "State of $A$ ll its Citizens" and Section $7 A$}

After Ben Shalom, the Supreme Court delivered two rulings dealing with the question of whether the idea of Israel being the state of all its citizens is one that negates Israel's existence as "a Jewish and democratic state". This question was discussed in Ben Shalom by Dov Levine. He found that since it does not represent any preference for the Jewish people as part of the essence of the state, this was enough to bring it within the scope of section $7 \mathrm{~A} .{ }^{56}$ The Supreme Court discussed the question again in the 1996 Isakson ruling, but this time in the context of section 5 of the Parties Law that is almost identical to section 7A of Basic Law: The Knesset. ${ }^{57}$ In

55 It should be mentioned that Amnon Rubenstein and Barak Medina favor a restrictive approach to interpreting and applying section 7A. They however, do recognize the legitimacy of approaches that seeks to broaden it. See Amnon Rubenstein \& Barak Medina, Constitutional Law of the State of Israel (in Hebrw), Gth ed, Jerusalem: Schocken Publishing House, 2005) vol 1 at 602-618.

${ }^{56}$ Ben Sbalom, supra note 47 at 242.

${ }^{57}$ Section 5 of the Parties Law-1992 provides that:

A party will not be registered if in one of its objectives or actions, explicitly or implicitly, is one of the following:

(1) The rejection of Israel's existence as a Jewish and democratic state.

(2) Incitement of racism;

(2a) Support for an armed struggle of an enemy state or a terrorist organization against the state of Israel;

(3) A reasonable basis to conclude that the party will be used for illegal activities.

For a discussion of this section, see section 3.4 below. 
Isakson, the Court rejected an appeal that demanded the reversal of the decision of the Parties Registrar to register a party whose platform calls for Israel to be a "state of all its citizens". 58 The leading opinion rejected the claim that this position negates Israel being a Jewish state. In rejecting the appeal, Justice Chechin asked rhetorically "[w] wo would accept the claim that the State of Israel is not the state of all its citizens? Is it possible to claim that the State of Israel is the state of part of its citizens only? Here is a fundamental principle in democracy: equality between citizens." ${ }^{59} \mathrm{He}$ also added, drawing parallels between a state and a corporation, that "all the citizens of Israel, Jews and non-Jews, are 'shareholders' in the state, and the statement that the state is 'the state of all its citizens' does not derogate from it being a Jewish state." Justice Tal, who concurred with Chechin's opinion, was more suspicious of the phrase. He said that there is some room to question whether "the authors of the [political] platform attribute to this innocent utterance a far-reaching meaning whose interpretation is that the state is the state of all its citizens to the point that its Jewish character is brushed aside by the opposing values and perspectives of a minority of its citizens." ${ }^{\prime 61}$ This, however, was not proven using clear, unequivocal and convincing evidence. Essentially, Dov Levine saw the idea of Israel being the state of all its citizens to be, in and of itself, a negation of its Jewish character. One the other hand, Chechin saw it as part of democracy, and thought that the Jewish and democratic definition tolerates such a characterization.

These two competing interpretations of the phrase "state of all its citizens" were further clarified in Tibi, a 2003 ruling in which the Supreme Court reversed the decision of the

58 CLA 2316/96 Isakson v Parties Registrar (1996), IsrSC 50(2) 529 (in Hebrew) [Isakson].

${ }^{59} \mathrm{Ibid}$ at 549 [translated by author].

60 Ibid at 549 [translated by author].

${ }^{61}$ Ibid at 558 [translated by author]. 
CEC to ban the National Democratic Assembly (NDA) party and its chairman, Azmi Bishara, from participating in the elections under section $7 \mathrm{~A}^{62}$ In this case, the Attorney General (Elyakim Rubenstein who later on became a Supreme Court judge) supported the disqualification of Bishara and NDA, and even submitted a request to the CEC supported by secret evidence collected by the General Security Services. In the hearing at the Supreme Court, the representative of the Attorney General argued that Bishara negates the existence of Israel as a Jewish state in light of his commitment "to the principle of equality, which will lead to the annulment of the commitment of the State of Israel to the Jewish foundational values and giving preference to other values." ${ }^{, 63}$ Equality, as embodied in the principle of "a state of all its citizens", according to the representative of the Attorney General, was seen as a threat to the Jewishness of the state. ${ }^{64}$

The Tibi case, decided by a majority of 7 to $4,{ }^{65}$ was the most elaborate explication of section $7 \mathrm{~A}$ and its interpretation, and the interpretation of the meaning of the Jewish state and whether it could be reconciled with the idea of a state of all its citizens. Then Chief Justice Barak wrote the leading majority opinion that provided a detailed interpretation of the "Jewish and democratic" definition. He explained that the definition combines two elements - a

${ }^{62}$ Tibi, supra note 1 . This decision dealt with a number of decisions to allow or ban participation of a number of people and parties, including Azmi Bishara, Ahmad Tibi, Bauch Marzel and the NDA. The CEC disqualified Bishara for negating the Jewish nature of the state and supporting armed conflict against Israel. Tibi was disqualified for negating the Jewish nature of the state. The CEC also refused to disqualify Marzel, a former aid to Kahane, from participating in the elections. The Supreme Court refused to confirm the decisions regarding Bishara (in a split decision) and Tibi (unanimously) and essentially reversed them. The Court also rejected -in a split decision- the appeal against the CEC's decision not to ban Marzel.

${ }^{63}$ Ibid at 34 [translated by author].

${ }^{64}$ As opposed to the situation in Canada and the United States, the Attorney General in Israel is not a political office. It is a professional and independent office, and the qualifying criteria are similar to the criteria required for a Supreme Court judge. The Attorney General is not seen as the government's lawyer, but rather as the guardian of the rule of law who is accountable to the law and not the government.

${ }^{65}$ The majority was composed of Aharon Barak, Eliahu Matza, Dalia Dorner, Dorit Beinisch, Yitshak Englard, Eliezer Rivlin and Ayala Procaccia. The minority judges were Shlomo Levine, Tova Strassburg-Cohen, Yakov Turkel, and Edmond Levi. 
democratic state and a Jewish state. The Jewish character of the state, being the "axiom" of the state, ${ }^{66}$ has many diverse characteristics, but for the purpose of section $7 \mathrm{~A}$ which deals with denial of rights, only the nuclear and minimal characteristics will be taken into consideration. These characteristics

have a Zionist perspective and a traditional perspective at the same time... At their center stands the right of every Jew to make aliy ${ }^{67}$ to the State of Israel, that in Israel Jews will be a majority, Hebrew will be the main official language of the state, and its main holidays and symbols reflect the national emergence of the Jewish people, the heritage of Israel ${ }^{18}$ is a central component of the state's religious and cultural heritage. A list of candidates, or a candidate, shall not participate in the election if their rejection or negation of these characteristics is central and dominant in their ambitions and activities, and they work vigorously to achieve these ambitions, and this should be proved using convincing, clear and unequivocal evidence. ${ }^{69}$

While the majority and the minority in Tibi had no disagreement on this interpretation, they disagreed on what Bishara and his party mean by "a state of all its citizens". Barak, who was joined by six other Justices, followed Chechin in Isakson and stated that if the objective of using the phrase is to secure equality among citizens, then there is no negation of the existence of the Jewish state. If the intention of using the phrase "aims for more than that, and it requests to undermine the rationale that is at the foundation of the creation of the state and thus negate the character of the State of Israel as the state of the Jewish people,"70 then this falls within section 7A. Barak went on to examine Bishara's intentions and noted that

[o]f course MK Bishara is not Zionist and he does not support the Zionist project. Nevertheless, he recognizes that the rationale for the creation of the State is Zionist. He recognizes that in Israel there is a Jewish majority and that its symbols and culture reflect this majority, but he is trying to give expression to the religion and culture of the Arab minority. ${ }^{71}$

${ }^{66}$ Tibi, supra note 1 at 21.

${ }^{67}$ A term in Hebrew which means "to ascend" that is used to describe Jewish immigration to Israel.

68 "Israel" here is used as the "people of Israel" in the religious sense which is synonymous with the Jewish people. The "heritage of Israel" is the heritage of the Jewish people.

69 Tibi, supra note 1 at 22 [translated by author].

${ }^{70}$ Ibid at 23 [translated by author].

${ }^{71}$ Ibid at 41 [translated by author]. 
Based on these observations, and after discussing the evidence, Barak concluded that the evidence adduced and the explanation by Bishara "leave room for doubt that should be for his advantage.,72

Barak's approach here, although detailed, is still somewhat ambiguous. It is not clear whether these demands of recognition of the "Zionist and traditional" characteristics of the Jewish state are to recognize these elements as facts, or as legitimate and desirable elements that ought to exist and should be preserved. On the one hand, the Jewish definition is treated as a normative precept, and Barak stressed that point. It follows that those elements which make up this normative precept are also normative in their nature and not factual. But when Barak applies the test, he treats the elements as facts, which were not denied by Bishara or NDA, and given the current situation, are impossible to deny: Israel does have a Jewish majority, and Hebrew is the main language, and the main religious and national holidays reflect the emergence of the Jewish people, and the Jewish religion and culture play a dominant role in the public culture of the state. This confusion between the normative and the factual, specifically on this point, may have been intentional. Asserting that it is not enough to recognize these elements as a matter of fact would have resulted in confirming the ban, which would in turn mean that a party would not have been allowed to participate in the elections because it calls for the state to be the state of all its citizens - a foundational idea in liberal democratic thought. Barak, in essence, avoided an absurd and indefensible situation. This dissonance could also be explained by Barak's reservation (but not departure) from the test that earlier cases adopted for the application of section $7 \mathrm{~A} .{ }^{73}$ The test, as applied by the

72 Ibid at 43 [translated by author].

${ }^{73}$ Neiman, supra note 44; Ben Sbalom, supra, 47. 
Court, asks whether the political platform of the party negates the existence of the state as a Jewish and democratic state, or incites racism, or supports armed conflict against Israel, and uses a high evidentiary standard. Barak, in addition to the high evidentiary standard, preferred a probability test: whether there is a serious chance that the objectives of the party could be achieved. Barak made a strong case for a probability test but stopped short of adopting it and left this point undecided and for future determination. ${ }^{74}$ But it may be that Barak's opinion in Tibi was shaped by the probability test without saying so, especially since Bishara and the NDA had no chance of achieving their goal of changing Israel into "a state of all its citizens". The party had only two seats at the time (out of 120 in the Knesset), and there was doubt whether it would pass the required electoral threshold of $2 \%$ of the popular vote. ${ }^{75}$ Nevertheless, even though Barak allowed the participation of Bishara and the NDA, he stated that Bishara's approach to the idea of the state being that of all its citizens "comes close, in a dangerous manner, to the possibility that negates the existence of the State of Israel as a Jewish state."76

The minority judges did not disagree with the principles that Barak set out in his opinion. Their disagreement centred primarily on the level of evidence needed to prove that Bishara and the NDA crossed the line. On the question of the phrase "state of all its citizens", one of the minority judges, Tova Strasberg-Cohen, stated that it is only a ruse to hide the real objectives of changing the Jewish character of the state. ${ }^{77}$ For Shlomo Levine, the context in which Bishara and the NDA use this expression shows that it is "a code name for annulling

\footnotetext{
${ }^{74}$ Tibi, supra note 1 at $20-21$.

${ }^{75}$ Barak Medina expressed similar doubts about the test that Aharon Barak uses. See Medina, supra note 34 at 376.

${ }^{76}$ Tibi, supra note 1 at 43 [translated by author].

${ }^{77}$ Ibid at 72.
} 
Zionism, annulling the state of Israel as the national homeland of the Jewish people and annulling the state as a Jewish state and replacing it with another state that will come in its stead." ${ }^{, 78}$ Concurring with Shlomo Levine, Justice Edmond Levi asserted that this change in the character of the state would be achieved using the demand for equality that could not be achieved as long as Israel sees itself as a Jewish state. ${ }^{79}$ Justice Strasberg-Cohen went as far as saying that according to section 7A of the Basic Law, even a position that sees reconciliation between the Jewish element and the democratic element as impossible will bring about barring the participation in the election. ${ }^{80}$

As in Ben Shalom, the discussion in Tibi demonstrates a debate between the different ways of understanding the "Jewish and democratic" nature of the state with the minority expressing the nationalist approach and the majority adopting a pragmatic or liberal nationalist approach, and both discussing whether Bishara, who is a critic of both approaches, should be allowed to stand in the elections. The margin of disagreement in this case was narrow, and the majority gave Bishara and NDA - in a manner that brings to mind criminal proceedings - the benefit of the doubt. An assessment of the majority position, however, reveals a trend: the likelihood of being banned from participating in the elections depends, to a certain extent, on the probability that a platform that challenges the Jewish character could be implemented. This can be seen clearly in Barak's strong argument for the "probability test", which, although not formally adopted, echoes in his opinion and the opinions of the other majority judges. For example, although Justice Dorner rejected the "probability test", she distinguished between political practice and ideology or "theoretical ideals". So while on the level of theory, NDA's

${ }^{78}$ Ibid at 82 [translated by author].

79 Ibid at 112 .

${ }^{80}$ Ibid at 71 . 
"state of all its citizens" is not a Jewish or a Zionist state, Bishara's activity in the Knesset shows that he did not try to implement his plan to change the Jewish identity of the state through legislation. ${ }^{81}$ This approach, even though it may allow more room of political participation, reveals a problematic trend: democratic values are allowed to prevail as long as they do not threaten the Jewish identity of the state. Practical steps to bring about change, even if within the formal democratic framework, are not tolerated. Even in this approach, the Jewish element sets the outer boundary of the democratic one.

The outcome of Tibi was confirmed in 2009 when the Court reversed a new decision by the CEC that disqualified the NDA from participating in the 2009 elections. ${ }^{82}$ Even though the Court allowed NDA to participate in the election in a split decision of 8 to 1 , this was done, as the then Chief Justice Beinisch explained, because of insufficient evidence. The party was given the benefit of the doubt, but the Court expressed the view that NDA's ideas are "in a disturbing and alarming proximity to the idea of the negation of the State of Israel as a Jewish state." ${ }^{83}$

\subsection{Other Grounds for Disqualification in Section $7 A$}

The discussion so far has focused on section 7A(1) of Basic Law: The Knesset that sets recognition of the Jewish nature of the state as a condition for participation in the national elections. This is the most significant and most commonly used subsection in this section with roots that go back 20 years before its initial enactment in 1985 as the forgoing overview

\footnotetext{
${ }^{81}$ Ibid at 98.

${ }^{82}$ EA 561/09 The National Democratic Assembly v. Central Elections Committee for the $18^{\text {th }}$ Knesset (2009) (unpublished) (in Hebrew).

${ }^{83}$ Ibid at para. 19 [translated by author].
} 
shows. The other sections, which could be seen as derivatives of subsection (1), are also important and should be briefly mentioned in our examination of barriers to representation.

Section 7A(3) of the basic law was enacted in 2002 to add the ground of "support for an armed struggle of an enemy state or a terror organization against the State of Israel". The subsection was designed and introduced specifically to target Palestinian politicians, ${ }^{84}$ and was used only against them. ${ }^{85}$ Given that section $7 \mathrm{~A}$ brings into consideration "the goals and actions" of candidates and parties expressed "explicitly or by implication", the potential scope of subsection 3 is very broad, especially in the context of the Israeli-Arab conflict. A majority of the Supreme Court justices, however, restricted its scope in the Tibi decision by requiring that the support, whether material or political, should be "a central or dominant characteristic" of the party and that this support be provided in a consistent and continuous manner and not just sporadically. ${ }^{86}$ The Court also stated that the evidence should be convincing, clear and unequivocal, and that there should be a "critical evidentiary mass". ${ }^{87}$ Subsection 3 was used once again in 2012/2013 to disqualify Haneen Zou'bi, and MK for NDA, from participating in the elections. The CEC's decision to disqualify Zou'bi was reversed by the Supreme Court. ${ }^{88}$

Section $7 \mathrm{~A}(2)$ includes inciting racism as grounds for disqualification. This provision was enacted as a reaction to the Court's refusal to disallow Kahane from presenting his candidacy for the elections in 1984. Kahane won a seat in those elections, and went on to

\footnotetext{
${ }^{84}$ See for example the discussion that took place on the bill for this amendment, Protocol No. 366 Meeting of Constitution, Law and Justice Committee, (22 October 2001). See also, Protocol No. 461 Meeting of the Constitution, Law and Justice Committee, (30 April 2002). See also Rubenstein \& Medina, supra note 55 at 639.

${ }^{85}$ See e.g. Tibi, supra note 1; EC 9255/12 Central Elections Committee for the Nineteenth Knesset v Zou'bi (2012) (confirmation rejected and decision to disqualify reversed, the Court has not provided the reasoning yet) [Zou'bi].

86 Tibi, supra note 1 at 27.

${ }^{87}$ Ibid at 43 [translated by author].

${ }^{88}$ Zou'bi, supra note 85.
} 
profess his racist ideology and to propose racist legislation. Kahane was subsequently disqualified in 1988 based on this subsection because of his racist platform. ${ }^{89}$ This subsection was construed in a very narrow manner to reduce its applicability. As such, calls for the transfer of Palestinians - which are essentially calls for committing a crime against humanity under international law - were not enough to bring the extreme right party Moledet within the ambit of section $7 \mathrm{~A}(2)$, neither were calls (or even proposed bills) to encourage the Palestinian citizens to emigrate from Israel..$^{90}$

\subsection{The Parties Law-1992}

Section 7A of Basic Law: The Knesset is only one barrier to political participation. Chronologically, it is a later barrier; a prior condition for participation in the elections is the existence of a party. ${ }^{91}$ Parties are regulated by the Parties Law-1992, which, in section 5, adopts a prohibition that is almost identical to section $7 \mathrm{~A} .^{92}$ Therefore, before getting to section $7 \mathrm{~A}$, a political group has first to go through the screening process of section 5 of the Parties Law. Because of the almost identical language used in both sections, the Supreme Court has adopted a similar interpretation for both provisions. ${ }^{93}$ At the same time, the Court has stated that there may be cases where a party may be able to get over section 5 of the Parties Law, but be disqualified according to section 7A. The Parties Law has procedural safeguards that are meant to prevent section 5 from being used in an arbitrary manner. Denial of registration by the Parties Registrar is subject to the confirmation of the Supreme Court [section 6(d)]. In

${ }^{89}$ Neiman, supra note 44.

90 Tibi, supra note 1 at $95-96$.

${ }^{11}$ Section 5A of Basic Law: The Knesset provides that "A list of candidates for the Knesset shall only be submitted by a party; the methods of incorporation and registration of parties and the conditions for submitting a list of candidates shall be determined in a law."

92 Supra note 57.

${ }^{33}$ CLA 7504/95 Yaseen v Parties Registrar (1996), IsrSC 50(2) 45; Isakson, supra note 58; Tibi, supra note 1. 
those cases the Court considers the issue as if it is making the decision itself and not sitting as an appeal court. ${ }^{94}$ Decisions of the Registrar to register a party could be appealed by third parties, but only after leave for appeal is granted by the Supreme Court [section 6(c)].

The discussion of section $7 \mathrm{~A}$ and the case law reveals that the definition of the state affects political representation in the parliament. The Supreme Court was split on this question with some justices favouring a broad understanding of the definition and rejecting the idea that Israel should be a state of all its citizens, and others, who have been the (narrow) majority, accepting a slightly narrower definition and exhibiting more tolerance for the idea of a "state of all its citizens" as long as it means an aspiration for equality and nothing more. While different judges approached the question from different points of view, all of them, along with many academics, have justified the restrictions using the principle of "defensive democracy". The following section will examine this idea, how different authors justify it, and how it is linked to the definition of the state as a Jewish state. Based on this examination, I will discuss how it affects the concept of the People in Israel.

\section{Debating Section 7A: Who is the People of the Defensive Democracy?}

\subsection{What does Defensive Democray Defend Exactly?}

The principle of defensive democracy is built on the idea that democracy as a system of governance should have mechanisms to protect itself. This is often translated into the idea that anti-democratic forces should not be allowed to benefit from the right to participate in elections since their goal is to eliminate democracy. ${ }^{95}$ This is quite understandable when it

\footnotetext{
${ }^{94}$ Yaseen, ibid.

${ }^{95}$ See Yerdor supra note 6; Tibi, supra note 1; Rubenstein \& Medina, supra note 55 at 588.
} 
comes to rejecting democracy or democratic principles such as equality or universal suffrage, but it becomes harder to justify when "defensive democracy" is invoked in order to exclude parties that reject the Jewish definition of the state, especially if this rejection is based on democratic and egalitarian principles. This contradiction has not been lost on many scholars. Fania-Oz Salzberger and Eli Salzberger, for example, observe that the Supreme Court, especially in the Yerdor case, transformed "the defense of democracy...into a defense of Zionism and of the Jewish character of the State of Israel." was not explained, and may have been unconscious. ${ }^{97}$ Nevertheless, the idea of "defensive democracy" has become so deeply entrenched in legal and academic discourses that the Court and academics use it to justify arrangements such as section $7 \mathrm{~A}$ and even torture. Even the General Security Service (SHABAK) characterizes any activity as "subversive" if it seeks "to change the basic values of the state and annul its democratic character or Jewish character". ${ }^{98}$ Similarly, according to the Attorney General, the SHABAK is authorized to use its surveillance and enforcement powers against these "subversive" activities."

Scholars who subscribe to nationalist and liberal nationalist ideas try to explain the tension in the invocation of the "defensive democracy" principle, and try to bring the defence of the Jewish nature into the defence of democracy. Ruth Gavison distinguishes between a situation where a party wants to change the character of the state, and a situation where a party seeks to delegitimize the state generally. Gavison would tolerate a party with a "preference" to change the Jewish character of the state to a "state of all its citizens" if that

${ }^{96}$ Fania Oz-Salzberger \& Eli Salzberger, "The Secret German Sources of the Israeli Supreme Court" (1998) 3:2 Israel Studies 159 at 175.

${ }^{97}$ Ibid.

${ }^{98}$ Letter from the Attorney General's Office to Adalah (20 May 2007), in Adalah Newsletter (May 2007 ) 36 online: <http://www.adalah.org/newsletter/eng/may07/5.php > (in Hebrew) [translate by author].

${ }^{99}$ Ibid. 
position is accompanied by a commitment to democracy and an acknowledgment that the majority does not accept such a demand. ${ }^{100}$ But she thinks that candidates or parties should be banned if they assert "that the continuing existence of Israel as a Jewish nation-state is not legitimate and could not be reconciled with democracy and human rights" ${ }^{\text {"101 }}$ because such a position means a rejection of the will of the majority, and a willingness to turn to "alien" elements in order to change it, a position which she sees as anti-democratic.

Gavison's position is problematic for several reasons. This justification could be applied to almost all parties whose platform focuses on contentious issues in Israel where there is dissatisfaction with an issue that is accepted by the majority. ${ }^{102}$ It may be the case, however, that Gavison means joining with other forces that are hostile to Israel. But joining these other forces is illegal under a myriad of anti-terrorism and emergency laws in addition to the fact that it will most likely fall under section $7 \mathrm{~A}(3)$ which makes supporting armed conflict by an enemy state or a terror organization a ground for disqualification. Gavison is trying to read violence into such a political position when it is not there. The distinction itself has its flaws: the distinction between what she considers permissible and what she considers intolerable is very fine and seems to imply that the issue of participation in the elections hinges on the consistency of the position against the definition as a Jewish state, and the determination to translate it into a political program. As long as it is a theoretical preference or

${ }^{100}$ Ruth Gavison, "Thoughts about the Significance and Implications of 'Jewish' in the Expression 'A Jewish and Democratic State"' in Aviezer Ravitzky \& Ydidia Z. Stern, eds, The Jewishness of Israel (in Hebrew) Jerusalem: Israel Democracy Institute, 2007) 107 at 165-167.

101 Ibid at 167 [translated by author].

102 Separation of state and religion is a good example. If a party asserts that the fact that there is no full separation of state and religion in Israel "is not legitimate and could not be reconciled with democracy and human rights" this party's position could also be seen as a rejection of the will of the people, especially if this party is willing to air its grievances on an international level, by approaching the UN Human Rights Committee for example. The same would apply to a range of other issues, such as civil (non-religious) marriage, gay marriage, the use of marijuana and public transportation on the Sabbath. 
an intellectual exercise, it is tolerable. But when it becomes an action plan that involves local and international actors, it becomes illegitimate and a reason to limit rights. This approach, although it echoes some of the opinions of the Supreme Court, undermines the very idea of political representation: representatives can be elected only as long as they do not try to advance their political platform. Since representation is organically connected to democracy and sovereignty, this position undermines and distorts representation of the Palestinian citizens for the sake of upholding the Jewish character of the state.

Amnon Rubenstein and Barak Medina offer a close and more detailed justification for using the "defensive democracy" concept. They offer two understandings of the concept. The first understanding entails the defence of a democratic regime from violent transformation. ${ }^{103}$ The second understanding views the features of democracy that need to be defended more broadly. In addition to democratic procedure, it also includes basic human rights including the right of the Jewish people to self-determination, which Rubenstein and Medina see as a precondition to the protection of the basic rights of the Jewish collective. ${ }^{104}$ They argue that the rejection of the importance of a Jewish majority or Jewish self-determination could result in endangering the life of Jewish citizens since this is the only possible way to secure the security of Jews. A bi-national arrangement instead of a Jewish state, for example, could result in "severe disturbances". ${ }^{105}$ A political party that aims to eliminate the Jewish character of the state is therefore seen as undemocratic for it disregards the wishes of the majority to define

\footnotetext{
${ }^{103}$ Rubenstein \& Medina, supra note 55 at 605.

104 Ariel Bendor presents a similar position that takes into consideration the state's "basic concepts" which include the Jewish nature of the state. He does not see that the state is "Jewish" because the majority decided it is. The Jewishness of the state for him is not subject to the determination of the majority, and the state, therefore, does not have to allow a majority to "eliminate" it as a Jewish state or allow conditions that would bring about this outcome. See Ariel Bendor, "The Candidacy Right in the Knesset Elections" (in Hebrew) (19871988) 18 Mishpatim, 269 at 275-276.

105 Rubenstein \& Medina, supra note 55 at 612.
} 
the state as Jewish. ${ }^{106}$ While they justify "defensive democracy" and section $7 \mathrm{~A}$ in principle, they have reservations about giving a political body such as the CEC the power to disqualify candidates and parties. They make an argument for transferring the powers of the CEC to an impartial judicial body. ${ }^{107}$

The justifications that Rubenstein and Medina provide raise questions about the conflation of democracy and the Jewish nature of the state. The justification for interpreting "defensive democracy" broadly to include the defence of the state as an exercise of the Jewish people's right to self-determination is problematic on a number of grounds. To begin with, the position stretches the right to self-determination to make fit situations where it does not necessarily arise. Another problem is that the right to self-determination they are claiming for the Jewish people excludes other peoples in Israel. The basic human right they are defending is applied here selectively to Jews only, and in effect negatively impacts other human rights of Israeli citizens, for the Palestinian citizens in Israel cannot partake in this right. ${ }^{108}$ In any case, the right to self-determination of the majority should not be used to trump individual rights to participate in elections, a basic tenet of democracy. To support such a position, as Rubenstein does, has far reaching implications, for Rubenstein (and many others such as Barak) see political participation as part of the way the People is made and exercises sovereignty. ${ }^{109}$

106 Ibid at 611 .

107 Ibid at 565.

${ }^{108}$ For the sake of clarity, Rubenstein and Medina do support self-determination for Palestinians, but in a Palestinian state, not Israel. This would include the Palestinian citizens of Israel.

${ }^{109}$ On this point, Rubenstein and Yakobson say that "in Israel the sovereignty is in the hands of the citizens of the state, including the Arab minority, which is operationalized by the institutions elected by these citizens, and by them only. The sovereign in the state is the same people which we mean when we say that the Knesset is elected by the people in democratic elections." Amnon Rubinstein \& Alexander Yakobson, Israel and the Family of Nations: A Jewish Nation State and Human Rights (in Hebrew) (Jerusalem: Schoken Publishing House, 2003) at 241 [translated by author]. The citation is to the Hebrew edition because the English translation does not include these lines. 
Infringement on rights of political participation, even according to Rubenstein's understanding, means an exclusion from the People.

Another major feature of Rubenstein and Medina's position, which is also palpable in Gavison's work, is that it betrays an unacknowledged colonial outlook. Their assertion that the absence of a Jewish state or the existence of a bi-national state will bring about violence and "severe disturbances" is problematic. It reflects a position that sees equal (even if limited) manifestation of Palestinian self-determination as necessarily causing violence, and that a Jewish majority is necessary for the security of the state, and even for democracy. ${ }^{110}$ This dichotomy that Rubenstein and Medina create -of Jewish majority or self-determination/ democracy versus Palestinian majority or a bi-national state/violence- echoes dichotomies that were created during colonial encounters in the sixteenth and seventeenth centuries. Anthony Anghie, speaking in the context of the development of the concept of sovereignty in international law, identifies an "endless process of creating a gap between two cultures, demarcating one as 'universal' and civilized and the other as 'particular' and uncivilized, and seeking to bridge the gap by developing techniques to normalize the aberrant society." "111 This process, which Anghie calls "the dynamic of difference" has animated the development of doctrine in international law. A similar process can be identified in Rubenstein and Medina's suggestion that an absence of a Jewish majority will cause violence and withdrawal of democracy. ${ }^{112}$ Section $7 \mathrm{~A}$ is therefore necessary to bridge this gap and normalize the "aberrant" Palestinian society and protect the Jewish majority by limiting the right to

${ }^{110}$ Rubenstein \& Medina, supra note 55 at 626 ("The loss of the Jewish majority will bring about the loss of the character of the state as a Jewish state (or as a democratic state), and a provision such as Section 7A of Basic Law: The Knesset will not help in this context" [emphasis added] [translated by author]).

111 Anthony Anghie, Imperialism, Sovereignty and the Making of Intermational Law (Cambridge and New York: Cambridge University Press, 2004) at 4.

${ }^{112}$ Rubenstein \& Medina, supra note 55 at 612. 
participation in elections. Even though the issue of colonialism was not discussed by Rubenstein and Medina or the Supreme Court, we can identify trends similar to the "dynamics of difference" both in the process of conceptualizing the difference and the process of "filling the gap".

Rubenstein and Medina argue that both approaches to "defensive democracy" are reasonable and justified although they prefer the approach that bans only those parties that intend to violently transform the state. ${ }^{113}$ Their preference is based on a mix of principled and utilitarian arguments. They acknowledge the difficulty that the broader approach is not based on universal democratic principles but rather on more particular conceptions of justice, and they acknowledge that it might have a negative impact by limiting the scope of discussion over the character of the state. On the more utilitarian side, they note that a restriction on the right to participate in elections will mean that fewer Palestinian citizens will vote and many will boycott the elections leading them to alternative and even violent forms of protest. They also have doubts about the effectiveness of this approach. If a growing number of people are opposed to the Jewish definition, section 7A will not help in the long run. ${ }^{114}$

Rubenstein and Medina argue that while the Supreme Court nominally adopts the broad understanding of "defensive democracy", in practice, and based on the outcome of the decisions dealing with section $7 \mathrm{~A}(\mathrm{a})(1)$, they argue the Court applied the narrow understanding that only justifies banning parties or candidates if they condone the use of violence. This position is based on the fact that since 1965, only one party has been disqualified (Al-Ard's Socialist List in Yerdor) and in that case there was a risk or suspicion of

113 Ibid at 605-606.

${ }^{114}$ Ibid at 624-626. 
violent intentions. This assertion, however, is weak. As Rubenstein and Medina observe, even in the Yerdor case the evidence connecting the candidates to violent threats against the state was very questionable and was more predicated on fear of Palestinian or Arab nationalism. ${ }^{115}$ But most importantly, if a court found that a party condones violence or organizes violent activities, the party could be excluded from the electoral process pursuant to section $7 \mathrm{~A}(\mathrm{a})(3)$ and would be outlawed under anti-terrorism legislation. Resort to section 7A(a)(1) would be unnecessary. A better explanation for the court rulings on section $7 \mathrm{~A}(1)$ is the one that I have provided above in the discussion of Tibi regarding the impact of a "probability test" on the judges' reasoning.

Mordechai Kremnitzer provides a more liberal approach. He argues that the negation of the Jewish character of the state should not be grounds for disqualifying candidates, and should be removed from section 7A. ${ }^{116}$ Like Rubenstein and Medina, his position is based on a principled commitment to democracy and utilitarian considerations. His position however reflects a stronger and more pronounced commitment to democratic principles, and goes as far as recommending the amendment of section $7 \mathrm{~A}$. He sees section $7 \mathrm{~A}$ as reflecting "paternalism, arrogance and even maltreatment of the Arab minority by the Jewish majority leaving the minority in a situation of endless threat of disqualification, a situation that allows the majority to determine the boundaries of thought and political action."117

115 Ibid at 608. As Pnina Lahav points out, citing Justice Cohen, that the CEC "had no proof, except the judicial holding and the subsequent executive declaration that Al-Ard was an illegal organization. The proof then, was embedded in the Court's holding from 1964. That holding was based first and foremost on an interpretation of Al-Ard's constitution provided by the military authorities." Pnina Lahav, Judgment in Jerusalem: Cbief Justice Simon Agranat and the Zionist Century (Berkeley: University of California Press, 1997) at 187-188.

116 Mordechai Kremnitzer, Disqualification of Lists (in Hebrew) (Jerusalem: Israel Democracy Institute, 2005) at 17 online: <http://www.idi.org.il/media/305798/pp_59.pdf>.

${ }^{117}$ Ibid at 51 [translated by author]. 


\subsection{Section $7 A$ and the People}

Section 7A and the justifications provided for adopting the exclusions it embodies have implications for who is included in the People in Israel, for elections are one of the ways that the political power of the People is transformed into the public authority of the state. Rubenstein, Medina and Kremnitzer touch on the impact of section 7A and acknowledge its problematic elements. Kremnitzer rightly acknowledges that this provision determines "boundaries of thought and political action". ${ }^{118}$ In essence, under the cover of "defensive democracy", section 7A subjects the political programs of the (mainly Palestinian) political parties to the scrutiny of the CEC and the Court, and these in turn examine to what extent these political programs challenge the principles of Zionism. The result is that political parties - especially those representing Palestinians - not only have to take into consideration the needs and wishes of their constituencies and members in devising their political programs, but also the principles of Zionism and the whims of the judges' interpretations. This outcome, furthermore, affects the Palestinian citizens as political actors not only on the level of daily politics and governance, but also on the constitutional level, i.e., on the level of shaping the rules of democracy since restricting access to the Knesset, which is a constituent body as well as a legislative body, means also exclusion from the constitutional rule-setting phase.

What does this tell us about the People in Israel? If we accept that sovereignty is vested in the People that exercises it in forming the constitutional order and through representation in the legislature, then we can see that there are serious doubts about whether the Palestinian citizens are included in the People. As a constitutional provision which embodies a foundational principle, section 7A (and its twin section 5 of the Parties Law) comes

118 Ibid at 51 [translated by author]. 
to protect a certain conception of the state and its character. The character is so important that it requires special protection from the state's own citizens. In this sense, it is doubtful that these citizens are included in the People that this constitution represents because the same constitutional order sees them as a threat and sets section $7 \mathrm{~A}$ to protect against them. Clear parallels could be drawn with settler colonial situations where the settler society exercises exclusive jurisdiction over the state. Section $7 \mathrm{~A}$ and the related sections in other statutes embody the "conflict over jurisdiction" that scholars such as James Tully identify as at the core of "internal colonialism". Since the state has exclusive jurisdiction in the case of Israel, entering and influencing one of the main organs of the state, the Knesset, becomes a first step in influencing how sovereignty is exercised. The conflict over sovereignty in this sense takes place at the gate of the Knesset, by deciding who and which ideologies can enter. Section 7A becomes the main instrument in this conflict over sovereignty. While section 7A, as we saw, does not necessarily block the access of Palestinian citizens to the Knesset, it does seek to block the access of ideas (and those who hold them) that reject Zionist principles and actively seek to challenge the status quo. This dynamic of allowing Palestinians to be elected, but to block ideas (and their bearers) is similar to the strategy of marginalization and assimilation used in settler colonial contexts. Those elected after the blocking of the "aberrant" ideas are still Arab members, but after blocking the challenging ideas with their demands to be regarded as equal constitutional actors, they become like all the other members of the Knesset who belong to specific "sectors" such as the religious or the ultra-orthodox sectors. In a sense, they are assimilated, in that their request for radical change is eliminated and their main demands, expressed as substantive equality, are marginalized. These strategies of marginalization and assimilation tend "to eliminate" the indigenous population as a political unit, but maintain its 
members as individuals with diluted political demands. Section 7A performs this function on the level of representation (which is the first step towards governance) by limiting access to the Knesset to those who agree with principles of Zionism and do not wish to challenge them. To put it in the words of former Chief Justice Meir Shamgar, section 7A functions to "screen, in advance, what the image of the Knesset and its elected members will be after the elections." ${ }^{\prime 19}$ In the context of the Palestinian citizens of Israel, this means, like indigenous populations elsewhere, that they can participate, but not as actors with demands to shape, influence and change the constitutional structure. They can play by the rules, but cannot participate in making them.

This exclusion from the People has serious and material implications for representation. Participation is conditioned on supporting (or at least not challenging) Zionism and the primacy of Zionism over other conceptions of the state such as a religiously and ethnically neutral state or a bi-national state. ${ }^{120}$ In this case, although section $7 \mathrm{~A}$ allows political participation, it dilutes its impact and acts as a shield that would ensure that the Jewish definition is not challenged through institutional means. Representation in this sense is conditional, and blocks access to various apparatuses of governance.

While these conclusions are based on the review of the case law in this chapter and the academic debates, it should be highlighted that the principles embedded in section $7 \mathrm{~A}$ are mediated by a number of factors. There is agreement that section $7 \mathrm{~A}$ should be used only in

\footnotetext{
${ }^{119} \mathrm{HCJ}$ 620/85 Mi'ari v Speaker of the Knesset (1987), IsrSC 41(4) 169 at 211 (in Hebrw) [translated by author]. 120 According to Section 57 (I) of Knesset Elections Law (Integrated Edition)-1969, a list of candidates should be submitted with a letter of authorization by each individual candidate. In this letter, according to Section 57(I1), each candidate must declare "I pledge to be loyal to the State of Israel and to refrain from acting [in a manner that is] contrary to the principles of Section 7A of Basic Law: The Knesset." [translated by author].
} 
the "most extreme cases"121, although the definition of what is considered "extreme" in this case is highly subjective. Additionally, judges and academics have expressed a range of views on the operation of section $7 \mathrm{~A}$ and its proper interpretation which creates significant grey area. Views also diverge on the proper test that should be used (for example, whether to adopt a probability test that perceived threats to the state are likely to materialize before excluding a party or candidate). A probability test would further narrow the scope of section $7 \mathrm{~A}$ but leave intact its formal exclusion. In addition, several procedural safeguards help minimize the range of cases that fall within section $7 \mathrm{~A} .{ }^{122}$ The ambiguities in the interpretation of section $7 \mathrm{~A}$ and its application, the procedural requirements and the close supervision by the Supreme Court do provide a measure of protection that make it difficult to disqualify a party or candidate disqualification using section $7 \mathrm{~A}$.

Those barriers, however, are not insurmountable. In most cases, the Court decisions allowing the contested parties to participate were split decisions. ${ }^{123}$ In decisions allowing participation, even the most liberal judges expressed hesitation and warned the parties that they were on the border of what is permissible under section 7A. Only a measure of doubt, akin to reasonable doubt in criminal proceedings, allowed their participation. On many occasions, as observed by Medina and by Kremnitzer, ${ }^{124}$ the judges used language that insinuated that participation in the elections was a matter of grace granted by the Jewish

121 Neiman, supra note 44 at 187.

${ }_{122}$ According to section 7A(b) of Basic Law: The Knesset and section 63A of the Knesset Elections Law (Integrated Edition)-1969, decisions to disqualify an individual candidate by the CEC are subject to the confirmation of the Supreme Court. In such cases the Court's scope of review is broader than in appeals and the Court becomes part of the decision making process. The panel of judges examining the case has to include at least nine judges. Decisions to disqualify parties (or lists as the text of the law provides) could be appealed as a matter of right to the Supreme Court (Section 64). As opposed to cases on individual candidates, the 3-judge panel is enough. See Tibi, supra note 1.

${ }_{123}$ The decision in Ben Shalom was a split decision (3 to 2), so was the Tibi decision (regarding Azmi Bishara) (7 to 4 ) and Balad (8 to 1) were split decisions.

${ }^{124}$ Kremnitzer, surpa note 116 at 48-49; Medina, supra note 34. 
collective rather than a right. ${ }^{125}$ These interpretative, procedural and evidentiary features of the jurisprudence have created a grey area that is often used by Palestinian parties such the NDA. This, in a sense, addresses, albeit partially, the problem of representation, and allows the participation of Palestinian parties with "threatening" political platforms. Still, the very fact that this is the result of receiving the benefit of the doubt and manoeuvring within grey areas points to a problem. Participation of Palestinian parties in elections is almost always uncertain, usually depends on court interventions - interventions whose outcomes are not certain.

These restrictions not only affect the conception of the People from a socio-legal point of view. They also affect the perception of constitutional membership of Palestinian citizens. An examination of the voting trends among Palestinian citizens shows that voter turnout has been consistently lower than the average in Israeli elections. In the past decade the Palestinian voter turnout has been falling consistently. In the 1999 elections, the rate was $75 \%$ (compared to $78.7 \%$ for the general population). It dropped to $62 \%$ for the 2003 elections ( $68.9 \%$ for the general population). The trend intensified in the 2006 and 2009 elections when the Palestinian voter turnout was $56.3 \%$ and $53.4 \%$ respectively, compared to $63.5 \%$ and $64.7 \%$ for the general population. ${ }^{126}$ The Palestinian turnout rate is substantially lower that the voter turnout rate of the Jewish population. Close to half of the members of the Palestinian

\footnotetext{
${ }^{125}$ Justice Turkul, for example, said about Azmi Bishara that he is "lucky that he lives and acts in a strong state that the value of democracy is so important for it that it is willing, in order to protect it, to allow expressions that are so blunt about the right of the state to exist. It would be good for those concerned if they see those expressions as the borderline of the protection of their democratic right to freedom of opinion and expression." EA 2600/99 Erlich v. Chairman of CEC (1999), IsrSC 53(3) 38 at 48 (in Hebrew) [translated by author].

126 "Voting Percentages in Past Elections" (2009) online: The Central Elections Committee $<$ http://www.bechirot.gov.il/elections19/eng/history/PercentVotes eng.aspx $>$. For percentages of the Palestinian voters turnout, see Karin Tamar Sheperman, "Participation, Abstention and Boycott: Trends in the Participation of the Arab Citizens of Israel in the Knesset Elections" (March 2009) 61 Parliament, online: The

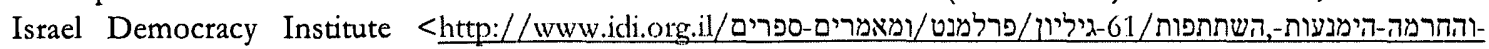
ילמות/> (in Hebrew).
} 
minority have chosen not to vote in recent elections. Asad Ghanem and Muhannad Mustafa explain that the declining Palestinian turnout rate is due to an increasing boycott or abstention which should be seen as a form of protest and expression of distrust of the parliamentary electoral process. This is motivated by the widespread view that Israel "does not tend to give 'real citizenship' to the Palestinians the country" that includes rights to equal political participation. ${ }^{127}$ Nadim Rouhana reaches a similar conclusion that the Palestinian citizens are at a stage where they question the nature of their citizenship and the relationship to the state it embodies. He further argues that even those who participate are motivated by factors other than a belief that they may influence law or policy. For example, absent other representative institutions, the Palestinian presence in the Knesset provides a necessary platform for giving voice to the collective. Rivalry between different political streams within the Palestinian minority also helps explain the vote; elections are used as a moment of mobilization on various levels. This mobilization contributes to extra-parliamentary organizing and cultural activities. ${ }^{128}$ This conclusion is supported by the fact that in the 2001 Prime Ministerial election only $18 \%$ of the eligible Palestinian voters participated. ${ }^{129}$

Another aspect of Israeli democracy, which is not directly related to section $7 \mathrm{~A}$ but still has an impact on the relationship between representation and membership in the People,

127 As'ad Ghanem \& Muhannad Mustafa, “The Palestinians in Israel and the 2006 Knesset Elections: Political and Ideological Implications of Election Boycott" (2007) 6:1 Holy Land Studies Journal 51 at 53-54.

${ }^{128}$ Nadim N. Rouhana, "The Shrinking Arab Vote in Israeli Parliamentary Elections: But Why Do they Still Vote?" (March 2009) 2 Jadal 20, online: <http://mada-research.org/en/files/2009/03/jadal2/jadal2-engfail/Jadal_Mar09 Eng-final1.pdf $>$. See also, Nadim N. Rouhana, Nabil Saleh \& Nimer Sultany, Voting Without Voice: The Palestinian Minority in the Israeli Parliamentary Elections (Haifa: Mada al-Carmel, 2003) (in Hebrew).

${ }^{129}$ The numbers based on sources Sheperman, supra note 126. The 2001 elections were for the position of Prime Minister only and not the Knesset. From 1996 until 2001 the Prime Minister was elected in direct elections, this was changed in 2002. The general turnout for the 2001 elections was also lower than previous elections at $62.3 \%$. The significant fall in the turnout among the Palestinian citizens could also be attributed to the fact that the "left" candidate at the time, Ehud Barak, who was the incumbent Prime Minister, was involved in the brutal suppression of the Second Intifada and the killing of the 13 Palestinian citizens who demonstrated in solidarity with the Palestinians in the OPT in October 2000. 
is participation in ruling coalitions. The exclusion of Palestinian parties from any ruling coalition has been an Israeli parliamentary convention since 1949. Even Jewish-Arab parties such as the Communist Party are excluded because of the vast support they command among Palestinian voters. Broad coalitions across the political spectrum, called "national unity governments", are formed every few years, and always exclude Palestinian parties from their "unity". The most influence on policy these parties have achieved was during Yitzhak Rabin's second government (1992-1996) when they obtained some changes in discriminatory policies in return for their support of the governing coalition on confidence votes in the Knesset. It should be noted that participation in a ruling coalition does not seem to be the ambition of these parties. Partnership in the ruling coalition comes with collective responsibility for the action of the government. As junior partners, the ability to influence policy is likely to be limited, while at the same time the public will see the coalition partners as having collective responsibility for the actions of the government. This would put Palestinian parties in the difficult position of apparently colluding in discriminatory policies, especially with regards to government policies in the OPT.

\section{The Jewish and Democratic Definition and the Elected Representatives}

While section 5 of the Parties Law and section 7A of the Basic Law: The Knesset represent barriers for political participation especially for Palestinian citizens, restrictions related to the definition of the state are also imposed on political parliamentary activities. Palestinian MKs have restrictions in their parliamentary work, both in its political aspects and legislative aspects. Restrictions related to the process of legislation will be discussed in the next chapter. This part will focus on restrictions on political activities. 
The restrictions embedded in the above-mentioned sections, in addition to the screening function they perform, are also intended to be "'red lines' that an MK must not cross". ${ }^{130}$ They accompany the work of MKs for as long as they are serving, and affect some of their rights, especially when it comes to immunity. According to section 1(a) of the Immunity, Rights and Duties of Knesset Members Law-1951,

A member of the Knesset shall not have criminal or civil liability, and he shall be immune from any legal action, for a vote or for expressing an opinion orally or in writing, or for an act that he carried out - in the Knesset or outside it - in the vote, expressing the opinion or the act were in the course of carrying out his duties, or for the purpose of carrying out his duties, as a member of the Knesset.

This section reflects the idea that MKs should be free to fulfill their duties and to express their opinions as representatives of the public without the fear of threat or intimidation, especially by the executive. This principle is set out in section 17 of Basic Law: The Knesset, which provides that "members of the Knesset shall have immunity: details will be determined in a law". Immunity, according to section 1 of the Immunity, Rights and Duties of Knesset Members Law, is substantive immunity, that is, it cannot be revoked by the Knesset. The immunity only applies to those activities related to carrying out the duties of a MK. It is not meant to allow illegal activities, but to protect the freedom and independence of the MK in cases where there is a risk that his/her actions "may slip, in their margins, towards prohibited activities."131 In those cases, the MK will not be held liable if his/her illegal action "is sufficiently close, from a substantive viewpoint, to the role of being a member of the Knesset, to the point that it can

$130 \mathrm{HCJ}$ 11255/03 Bishara v Attorney General (2006), IsrSC 60(4) 287 at 301 (in Hebrew) [translated by author] [Bishara].

${ }^{131} \mathrm{HCJ}$ 1843/93 Pinbasi v The Knesset (1996), IsrSC 49(1) 661 at 686 (in Hebrew) [translated by author]. 
be said that it is a part of it and it constitutes a part of the natural risk to which every member of the Knesset is exposed."132 This approach is known as the "margin of natural risk test".

Substantive immunity, however, has its exceptions. It does not apply, as section 1(a1) explains, in situations similar to those in section 7A of Basic Law: The Knesset, ${ }^{133}$ for this would be seen as "crossing the red lines." These lines include the Jewish and democratic definition of the state, incitement to racism, and supporting an armed struggle against the state. Although this section was added in a 2002 amendment, the Supreme Court stressed its declaratory nature, and highlighted that it only confirms the legal situation that existed prior to its enactment. ${ }^{134}$ Essentially it sets out the contours of what an MK can say or do, and excludes from the protection against prosecution a number of issues, which include the definition of the state and support for armed struggle. This section is most relevant when it comes to expressions of support for armed struggle because of the abundance of legislation that criminalize these activities, as opposed to the other grounds which rarely come within the ambit of criminal law or civil liability. ${ }^{135}$

\footnotetext{
132 Ibid.

${ }^{133}$ Section 1(a1) of Immunity, Rights and Duties of Knesset Members Law provides:
}

(a1) To remove doubt, an act, including a statement, which is not incidental, of a member of the Knesset that contains one of the following shall not be regarded, for the purpose of this law, as expressing an opinion or as an act that is carried out in the course of his duties or for the purpose of his duties as a member of the Knesset:

(1) Denying the existence of the State of Israel as the state of the Jewish people;

(2) Denying the democratic character of the state;

(3) Incitement to racism because of colour or belonging to a race or to a national-ethnic origin;

(4) Support for an armed struggle of a hostile state or for acts of terrorism against the State of Israel or against Jews or Arabs because they are Jews or Arabs, in Israel or abroad.

134 Bishara, supra note 130.

135 There is no criminal prohibition on denying the Jewish or democratic character of the state, although in a minority opinion in Mi'ari Justice Ben Porat saw speaking at a meeting organized by individuals close to the PLO, and expressing sympathy with the PLO goals, to be tantamount to denying the Jewish character of the state. Mi'ari, supra note 119 at 225-227. Criminal provisions outlawing racial incitement are construed very narrowly and are very rarely initiated. 
So far, there has only been one case dealing with the scope of the immunity regarding political activities and statements after the 2002 amendment. The Supreme Court, in a 2 to 1 decision, decided that statements Azmi Bishara made as an MK in support of resisting the occupation of south Lebanon (1982-2000), should be seen as part of carrying out his duty. The disagreement was on the interpretation of the phrase "support for an armed struggle" and the scope of evidence required. The majority, Barak and Rivlin, following an earlier determination in Bishara's elections appeal dealing with section $7 \mathrm{~A}$, decided that the support for an armed struggle should be support of a specific group, and should be consistent and absolute, and not just a simple statement. ${ }^{136}$ In the minority opinion, Justice Hayut took the view that "support for armed struggle" for the purpose of the Immunity, Rights and Duties of Knesset Members Law should be given a different meaning than in the context of section 7A, and decided that the threshold should be lower. Her reasoning was based on the view that section 7A and section 5 of the Parties Law entail an a priori restriction of the right to participate in elections. Restriction of immunity on the other hand is an after the fact restriction of immunity. The majority disagreed, and stressed that immunity is still important for political representation, especially for minority groups, in order to secure the democratic character of the regime. ${ }^{137}$

Restricting parliamentary immunity for activities that are political in nature and related to political expression is rare, given that prosecutions of MKs based on statements or political activities are also rare. The Supreme Court has thus far provided a narrow interpretation of the restrictions. This interpretation, however, is based on one split decision, and it may be too

136 Bishara, supra note 130 at $317-318$.

137 Ibid at 320. 
early to speculate on how this rule will develop in the future. One interesting (and worrying) fact in this context is that almost all attempts to restrict substantive immunity for political activities or statements have so far targeted Palestinian Members of the Knesset only. ${ }^{138}$

\section{Summary and Conclusions}

Ever since the Yerdor ruling in 1965, the idea that challenges to the Jewish character of the state also mean a threat to democracy and the state as a whole, has taken root in the Israeli constitutional system and become one of its foundational principles. The idea was added to the written constitution through the enactment in 1985 of section 7A of Basic Law: The Knesset, and later was added to the Parties Law- 1992 and the Immunity, Rights and Duties of Knesset Members Law-1951. The trend in legislation enacted by the Knesset has been to expand the scope of this doctrine - by adding new grounds of exclusion, such as support for armed struggle, and applying it to the various stages of the political process, such as registration of parties and parliamentary immunity. The trend in the case law has been to narrow the scope of the legislative restrictions. But this judicial trend has been expressed reluctantly and is qualified by many ambiguities and grey areas.

While section 7A does impose restrictions on the right to be elected (and the right to vote by extension), it has wider implications for the idea of who is included in the People in Israel. In essence, section 7A (and the other associated sections discussed in this chapter) subject the political programmes of the (mainly Palestinian) political parties to the scrutiny of the courts to examine the extent to which they challenge the principles of Zionism. Even

${ }^{138}$ So far there have been four cases, Mi'ari, supra note 119; Bishara, supra note 130; Serious Crim File(Nazareth) 47188-12-11 State of Israel v Nafa' (2012) (pending); Crim File (Tel-Aviv) 12318-12-09 State of Israel v. Barakeh (2011). 
though since 1965 no political party has been banned from participating in elections for challenging the Jewish definition of the state, and the only party to be banned was on the grounds of racism (Kach in 1988), the very existence of section 7A affects the broader political discourse and the political sphere of the Palestinian minority. Some political groups cannot participate in elections because of the requirements of section $7 \mathrm{~A}$, and those who participate are always preoccupied with the possibility of being banned. The provision of section 7A(a), as explained in Tibi, dictates the "red lines", the outer limits of what the Zionist consensus sees as a reasonable and acceptable political discourse beyond which political parties cannot go. The restrictions that section $7 \mathrm{~A}$ imposes and the way it has been interpreted by the Supreme Court make it hard to devise a political program that can directly challenge the structural bias and the colonial reality embedded in and protected by the state's definition. Some parties try to challenge the different components of the structural problem by highlighting the citizenship discourse, equality, and individual and collective rights. This, according to some opinions in the Supreme Court, is sufficient to bring them within the ambit of section 7A. As a result, the political programmes usually shy away from producing frontal attacks on components of the Zionist ideology such as the Law of Return or the Jewishness of the state as such. A political programme, for example, that endorses a one-state solution or a bi-national constitutional arrangement for Israel, even if it adheres to the strictest principles of anti-racism, democracy and human rights would be - even by the most liberal judicial opinions - grounds for a ban. Nevertheless, the interpretation of section 7A leaves some grey areas for manoeuvring and challenging the fundamental features of the state, which is used effectively by some parties like the NDA. 
Even though the use of section $7 \mathrm{~A}$ has been rare, the very existence of such a constitutional provision is problematic. Its constitutional entrenchment affects the Palestinian citizens as political actors by delineating the permissible range of political belief and activism in a manner that does not necessarily apply in the same way to Jewish citizens. And since section $7 \mathrm{~A}$ is the gatekeeper for who enters the Knesset, which is both the legislator and the constituent body, it essentially ensures that the rules cannot be changed democratically. Section 7A and the other similar provisions essentially act like multi-layered filters that are meant to catch "aberrant" political views so that they do not affect the image of the Knesset, as Chief Justice Shamgar explained.

Even if some ideas are allowed through the filters, their influence on the Israeli government is limited because of the exclusion of Arab parties from governing coalitions, and also because of the structure and design of the constitutional order in Israel. These aspects are related to the function of the Knesset as a legislature and a constituent body, and the function of the courts as interpreters of the law and guardians of the constitution. In essence, they affect the constitution in action; the manner and results of this action further strengthen the conclusions of this chapter regarding the People. 


\title{
Chapter VI
}

\section{The Constitution in Action: Constitutional}

\author{
Amendments, Law, and Governance
}

\section{Introduction}

In Israel, the sovereign is the people. The people elects the Knesset. The Knesset is "the house of representatives of the State" (section 1 of Basic Law: The Knesset); it is "the house of legislators" (section 1 of the Transition Law- 1949). The Knesset expresses its will through basic laws and 'regular' laws. Those establish the material decisions on the policy of the state and the needs of the society. The Israeli democracy, therefore, is a representative democracy. The people speaks through its representatives, and the representatives speak through their legislation. ${ }^{1}$

While section 7A of Basic Law: the Knesset embodies one of the most explicit ways the Jewish and democratic definition affects representation and political participation, it is only one facet of a multilevelled and multifaceted structure. The impact of the definition on the sphere of governance is not limited to this section. The definition of the state is relevant on a number of levels and its impact goes far beyond the electoral process. In addition to the limitation it imposes on the electoral process and the immunity a Member of the Knesset (MK) enjoys, the definition also plays a role in the process of legislation, constitutional amendment, statutory interpretation, and judicial review of legislation. To understand the implications of the definition and the role it plays in the process of governing, it should be situated in a broader examination of the Israeli constitutional system. To this end, in this chapter, I will map out the different ways the Jewish and democratic definition affects the processes of law-making and governing, which reflect the transformation of political power

${ }^{1}$ HCJ 1661/05 Gaza Sbore Regional Council v The Knesset (2005), IsrSC 59(2) 481 at 565. (in Hebrew) [translated by author] [Gaza Shore Regional Council. 
generated by the people into public and legal authority through legislation and executive power. By examining different aspects of the constitutional system in Israel and its ways of operation, I will argue that the state definition does not merely affect Knesset elections, but is embedded in the constitutional structure at various levels and in different ways, and operates, as a matter of law, in a manner that concentrates political power in the hands of the Jewish citizens and excludes the Palestinian citizens.

The discussion of the role of the definition in the constitutional edifice will begin with an examination of its role in the passage of basic laws and statutes by the Knesset. The definition plays a role on both levels (the constitutional and the legislative) but in different ways. After the legal and constitutional norms are made by the Knesset, they leave the domain of the legislature (which is also the constituent body) and enter the province of the judiciary which interprets, and in some cases, has the power to invalidate those norms if found to be unconstitutional. Here I will examine how the definition plays a role in those situations. The definition is also embodied in some pieces of legislation that will be discussed in this chapter.

\section{The Jewish and Democratic Definition in the Process of Constitution-Making}

The basic laws are the (partial) constitution of Israel. They have a higher status than regular legislation passed by the Knesset. The courts can invalidate regular legislation if it contains provisions that are contrary to the basic laws. Regular legislation cannot amend a basic law. ${ }^{2} \mathrm{~A}$ basic law can be amended only by another basic law, although the process of enactment and amendment of regular legislation and basic laws is the same. ${ }^{3}$ Some provisions

\footnotetext{
2 CA 6821/93 Bank Mizrabi HaMe'ouba v. Migdal Kfar Shitofui (1995), IsrSC 49 (2) 221 (in Hebrew) [Bank Mizrabi].

${ }^{3}$ Part 7 of the Rules of Procedures of the Knesset, online: <http://knesset.gov.il/rules/eng/contents.htm $>$.
} 
of the basic laws are "entrenched", and can be amended only with the approval of a special majority. ${ }^{4}$

The constitutional status of the basic laws has not always been taken for granted. For a long time the courts treated basic laws as regular legislation. It is only in the past twenty years that the "Constitutional Revolution" took place and the Supreme Court declared the basic laws to be as part of the constitution.

\subsection{The Basic Laws and their Status: The Constitutional Revolution}

Historically, and for many reasons, Israel did not adopt a formal constitution despite the fact that the Declaration of Independence and the Partition Plan stipulated that a constitution should be adopted. The Declaration of Independence stated that a Constituent Assembly would adopt a constitution by 1 October 1948 . This constitution would determine the various arrangements for the state and its authorities. ${ }^{5}$ The Constituent Assembly was not elected until 1949, and before it was elected, the Temporary State Council - which was formed by the leaders of the Jewish Yishuv as an interim body to run the affairs of the state until elections were held - decided that its powers would be transferred to the elected Constituent Assembly which would act both as the constituent assembly and the legislator. ${ }^{6}$ With the conclusion of the 1949 elections, the Constituent Assembly was convened, and it enacted The Transition Act1949. The Act changed the name of the Assembly to the First Knesset.

\footnotetext{
${ }^{4}$ See e.g. section 4 of Basic Law: The Knesset which stipulates that "The Knesset shall be elected by general, national, direct, equal, secret and proportional elections, in accordance with the Knesset Elections Law; this section shall not be varied save by a majority of the members of the Knesset." [translated by author]. Section 44(a) of Basic Law: The Knesset also requires a special majority for any amendment.

5 Declaration of Independence of the State of Israel. See also Amnon Rubenstein \& Barak Medina, Constitutional Law of the State of Israel (in Hebrew), 6th ed, (Jerusalem: Schocken Publishing House, 2005) vol 1 at 35.

${ }^{6}$ Section 3 of Transition to the Constituent Assembly Ordinance, 1949. See also, Rubenstein \& Medina, ibid at 36.
} 
The First Knesset held a number of discussions on the constitution without adopting one. Instead it decided to impose on the Constitution, Law and Justice Committee of the Knesset the task of preparing a draft constitution. It also decided that the constitution would consist of different chapters, and each chapter would constitute a separate basic law. The chapters would then be "brought before the Knesset" and all of the basic laws would be incorporated into the constitution. ${ }^{7}$ This decision came to be known as the Harari Decisionafter the Member of Knesset who proposed the arrangement. Before it was dissolved, the First Knesset passed legislation that provided that the Second Knesset, and subsequent sessions of the Knesset, would have all the powers that the First Knesset had, which included constituent power, the power to adopt a constitution. Thus, the Harari Decision and the Transition Act preserved the Knesset's constituent power. ${ }^{8}$

Since the Harari Decision in 1950, the Knesset has enacted eleven basic laws, but the courts never declared or saw them as constitutional until 1995. At that time, only entrenched provisions of the basic laws that required a special majority to amend were seen at a higher normative level than regular legislation. 'The constitutional nature of those basic laws and their superiority over "regular legislation" was confirmed by the Supreme Court in the Bank Mizrabi decision in $1995 .{ }^{10}$ A number of reasons were suggested to explain the reluctance to adopt a full formal constitution in the early years of the state. One of the main reasons was the desire of the ruling elites, represented by the MAPAI Party (an earlier incarnation of today's

7 Ibid at 37.

${ }^{8}$ Bank Mizrabi, supra note 2 . It is worth mentioning the dissenting opinion of Justice Michel Chechin in the same decision, which asserted that the constituent power of the First Knesset has expired with the expiry its term. The First Knesset could not have passed its constituent power. It only passed its legislative powers.

${ }^{9}$ HCJ 98/69 Bergman v Minister of Finance (1969), IsrSC 23(1) 693 (in Hebrew); HCJ 246/81 Derekh Eret? Association v Broadcasting Authority (1981), IsrSC 25(4) 1 (in Hebrew).

${ }^{10}$ Bank Mirrabi, supra note 2. 
Labour Party) whose members formed the majority in the Knesset at the time, to maintain political power in the hands of the executive without the limits imposed by a constitution. ${ }^{11}$ Other reasons included the unwillingness or inability to make decisions on key issues such as the role of religion, the relationship between the state and the Palestinian minority, and the state's economic policies. ${ }^{12}$ Until the early 1990 s, the doctrine of parliamentary sovereignty, reflecting the influence of the English system, reigned supreme. ${ }^{13}$ The decline of this doctrine started in the late 1980 s. The Court, or at least some judges, began to muse about the idea that the Court can strike down legislation that is contrary to "the fundamental principles of the system." In an obiter dicta (in a decision where he was in the minority) from 1990, Justice Barak wrote that

theoretically and as a matter of principle, there exists the possibility that a court in a democratic society declares the invalidity of a law that is contrary to the fundamental principles of the system; even if those fundamental principles are not entrenched in a rigid constitution or an entrenched basic law. There is nothing axiomatic about the approach that legislation could not be invalidated because of its content. ${ }^{14}$

Although Barak defended the legitimacy of such an approach, he emphasized that as a matter of law, the "Court cannot take for itself this authority to declare the invalidity of legislation that is contrary to the fundamental principles of our system."15 This position, he explained,

\footnotetext{
11 Gershon Shafir \& Yoav Peled, Being Israeli: The Dynamics of Multiple Citizenship (Cambridge: Cambridge University Press, 2004) at 261; Ran Hirschl, “The Socio-Political Origins of Israel's Juristocracy” (2009) 16:3 Constellations 476 at 483.

12 Ruth Gavison, “The Controversy over Israel's Bill of Rights” (1985) 15 Israel Yearbook on Human Rights 113 at 149; Hana Lerner, "Democracy, Constitutionalism, and Identity: The Anomaly of the Israeli Case" (2004) 11:2 Constellations 237.

${ }^{13}$ See e.g. HCJ 780/83 Yeshivat Tomchei Tmeemeem Mercazit v. State of Israel (1984), IsrSC 38 (2) 273 (in Hebrew); HCJ 761/86 Mia'ari v. Speaker of the Knesset (1987), IsrSC 42(4) 868 (in Hebrew). It should be mentioned, however, that the Knesset and the Court did accept that the Knesset could limit its capacity to legislate in the future by requiring a special majority. Such limitation is a breach of parliamentary sovereignty under UK law.

${ }_{14}$ HCJ 142/89 La'or Movement v. Speaker of the Knesset (1990), IsrSC 44(3) 529 at 554 (in Hebrew) [translated by author].

${ }^{15}$ Ibid at 554 [translated by author].
} 
was developed over years, and reflects the heritage of the English system, and the "social agreement in Israel, and it enjoys consensus of the enlightened public."16 Barak added that "it is not appropriate" for the Court to change this situation. Change should be made through "the people and its elected representatives." ".7 Some saw this long obiter (almost four pages out of a 19 page opinion) as an indication for the future. ${ }^{18}$

And change - at least according to some - did come in 1992 in the form of two basic laws that the Knesset adopted. Although attempts were made in the 1980 s to adopt a bill of rights, none of them were successful. ${ }^{19}$ Partial success was achieved in 1992 with the enactment of Basic Law: Freedom of Occupation and Basic Law: Human Dignity and Freedom. Both basic laws were enacted after a failed attempt to pass Basic Law: Basic Human Rights, which was a bill for a broader basic law dealing with rights. When the attempt failed, individual members of the Knesset, led by Amnon Rubenstein who was then a member, tried to salvage whatever was possible from the failed bill, and included a number of rights that were not seen as controversial in two basic laws they proposed in a private bill. A number of rights such as equality and freedom of expression were intentionally excluded because they were seen as controversial. $^{20}$

There was nothing exceptional about the process of adoption or the debates in the Knesset, nor was it accompanied with any public debate on the changes that the basic laws

${ }^{16}$ Ibid [translated by author].

17 Ibid [translated by author].

${ }^{18}$ Gideon Sapir, Constitutional Revolution in Israel: Past, Present and Future (in Hebrew) (Tel Aviv: Yedioth Aharonoth Books and others, 2010) at 57 [Sapir, "Constitutional Revolution in Israel"].

${ }^{19}$ There were some attempts in the 1950s, 1960s. The attempts intensified in the late 1970s and the 1980s. Barak chronicles the history of these failed attempts in his opinion in Bank Mizrabi, supra note 2 at 369-378.

${ }^{20}$ Yehudit Karp, "Basic Law: Human Dignity and Freedom- Biography of Power Struggles" (in Hebrew) (1993) 1 Mishpat O Mimshal 323 [Karp, "Basic Law"]; Amnon Rubenstein, "The Knesset and the Basic Laws on Human Rights" (in Hebrew) (2000) 5 Mishpat o Mimshal 339. 
accomplished. The enactment was not celebrated as a historic moment or a milestone in the development of Israeli constitutional law, even though it marked the departure of Israel from the common law parliamentary sovereignty system to a constitutional system where the courts have the power to review legislation. Less than half of the members of the Knesset bothered to participate in the vote on the first reading of Basic Law: Human Dignity and Freedom. ${ }^{21}$ Basic Law: Freedom of Occupation was adopted with the votes of only 23 members of the Knesset, less than one fifth of $\mathrm{MKs} .^{22}$ In fact, as it turns out, a number of members of the Knesset who voted did not intend to make this change nor give the court that power. ${ }^{23}$ With the exception of a small number of opinion pieces in newspapers, from the point of view of the broader public, and even the majority of the legal community, it was a non-event. ${ }^{24}$ Despite the lack of public debate or media interest in the two basic laws and the potential changes they could achieve, Barak declared in a lecture he gave two months after their enactment that these two basic laws "created a revolution in the legal and constitutional status of the basic human rights in Israel."25 "The essence of the revolution", Barak explained,

\footnotetext{
${ }^{21} 41 \mathrm{MKs}$ voted in favor and 12 against in the first reading. See ibid at 346 . In the third reading 32 voted in favor and 21 against. See Ruth Gavison, "The Constitutional Revolution - A Description of a Reality or a Self-Fulfilling Prophecy?"(in Hebrew) (1997) 28 Mishpatim 21 at 94 [Gavison, "Constitutional Revolution"].

22 Yehudit Krap, "Basic Law: Human Dignity and Freedom- Biography of Power Struggles" (1993) 1 Mishpat O Mimshal 323 at 327 (Hebrew).

${ }^{23}$ Gavison, "Constitutional Revolution", supra note 21 at 94; Gideon Sapir, "Constitutional Revolutions: Israel as a Case-Study" (2009) 5(4) International Journal of Law in Context 355, 366-371 [Sapir, "Constitutional Revolutions"].

${ }^{24}$ This indifference of the media and the legal community is best described using Aharon Barak's words. In an interview he gave to the magazine of the Israel Bar Association, he said, describing the reception of the basic laws: "In March 1992 two basic laws are issued in absolute silence. March passed, April, May - and nothing, not even one thing, and I read the two basic laws and I say to myself: this is our constitution. And then in a short lecture I gave, I talked about the constitutional revolution." Cited in Gavison, "Constitutional Revolution", supra note 21 at 96, n 177 [translated by author]. Even Amnon Rubenstein, the main power pushing for the adoption of the basic laws, acknowledged that there was little public interest. See Rubenstein, supra note 20 at 349.

${ }^{25}$ Aharon Barak, "The Constitutional Revolution: Protected Human Rights" (in Hebrew) (1992) 1 Mishpat o Mimshal 10 at 12 [Barak, "The Constitutional Revolution"] [translated by author].
} 
is not in the content of the human rights but in their validity. From now on, the basic rights are binding on the legislature itself. No longer should it be said that Israel does not have a "written constitution" (formal and rigid) regarding human rights. The new legislation took Israel out of its solitude, and placed us in the large camp of states where human rights are anchored in a "written" and "rigid" constitution, that is, is a document that has normative supremacy or preference. ${ }^{26}$

Shortly after this lecture and its publication in an academic journal, a wave of academic writing tackled the question of the status of the new basic laws. ${ }^{27}$ Barak himself, in a series of publications, continued expounding on the new basic laws and laid down his vision for their role in human rights protection and the role of the Court. ${ }^{28}$ As the discussion on the new basic laws and the constitutional revolution intensified, the courts started referring to and using them in their decisions. In an obiter dicta in a decision that was issued in 1993, the Supreme Court discussed the impact of Basic Law: Freedom of Occupation on regulations banning the importation of non-kosher meat. The Court stated that the enactment of the basic law, although it did not affect the validity of the relevant legislation, did affect its interpretation. It also added a cautionary note that future legislation that restricts freedom of occupation should take into consideration the new basic law to be valid. ${ }^{29}$ In 1995 the Supreme Court issued a decision where it ruled that despite section 10 of Basic Law: Human Dignity and Freedom - which states that the basic law does not affect the validity of earlier law - the enactment of the basic law and the constitutional revolution it produced have a bearing on the interpretation of

${ }^{26}$ Ibid at 13 [translated by author].

${ }^{27}$ See e.g. Karp, "Basic Law", supra note 20; David Kretzmer, "The New Basic Laws on Human Rights: A MiniRevolution in Israeli Constitutional Law?" (1992) 26 Israel Law Review 238; Menachem Elon, "Constitution Through Law: The Values of a Jewish and Democratic State After Basic Law: Human Dignity and Freedom" (in Hebrew) (1993) 13 Iyounei Mishpat 659.

${ }^{28}$ See e.g. Aharon Barak, "Protected Human Rights: Scope and Limits" (1993) 1 Mishpat o Mimshal 253; Aharon Barak, "Protected Human Rights and Private Law" in Yitshak Zamir, ed, The Klinghofer Book on Public Law (in Hebrew) (Jerusalem: Harry and Michael Sacher Institute for Legislative Research and Comparative Law, 1993). ${ }^{29}$ HCJ 3872/93 Mitral Ltd. v Prime Minister and Minister of Religions (1993), IsrSC 46(5) 485. 
earlier laws. ${ }^{30}$ This paved the way for the landmark Bank Mizrabi decision which confirmed that a revolution had actually taken place.

In Bank Mizrabi the status of the basic laws was finally clarified. In a decision that spans over 519 pages, the Court declared, in a split decision, ${ }^{31}$ that the basic laws have a constitutional status that is higher than "regular" legislation, and that by adopting those basic laws, the Knesset was exercising its constituent power. Expounding his "two hats" theory, then incoming Chief Justice Barak explained that the Knesset has the authority to legislate and to adopt a constitution. But where does this power to adopt a constitution come from? Barak explained that

at the foundation of the theory of the constituent power of the Knesset stands the perception that the constituent power of the Knesset comes from the sovereign, that is the people. By virtue of this constituent power, the Knesset gives a constitution to Israel (in the form of basic laws). By virtue of these [basic laws] the Knesset is given the power to legislate 'regular' legislation and use other powers (like supervision over the government). Indeed, the Knesset has a number of 'hats' or 'crowns', and one of them is the crown of constituent power, by virtue of which it constitutes the constitution (basic laws), and legislation is made by virtue of the crown of the legislative power. ${ }^{32}$

How did the Knesset acquire constituent power? Barak suggested three models that support his position: Hans Kelsen's grund norm, H.L.A Hart's rules of recognition and a model inspired by Ronald Dworkin's Law's Empire that takes into consideration the social and legal history of the legal system. ${ }^{33}$ After reviewing the history of the creation of the state, the attempts to adopt a constitution, and the different legal and political debates on the issue,

${ }^{30}$ CrimVR 537/95 Ghneimat v. State of Israel (1995), IsrSC 49 (3) 355. Affirmed in CrimFH 2316/96 Ghneimat v. State of Israel (1995), IsrSC 49(4) 589 (in Hebrew).

31 The panel included 9 Justices. The majority included 7 Justices, one Justice dissented, and one Justice refused to engage with the question, which, despite its importance, was essentially an obiter. According to Eli Salzburger, of the 519 pages of the Bank Mizrabi ruling, 457 were obiter, and only 62 dealt with questions that the Court needed to decide the appeal. See Eli Salzburger, "Constituent Power in Israel - Two Incidental Comments to an Obiter, or an Invitation to Re-open the Discussion" (in Hebrew) (1996) 3 Mishpat o Mimshal 679.

32 Bank Mizrabi, supra note 2 at 360 [translated by author].

${ }^{33}$ Ronald Dworkin, Law's Empire (Cambridge, MA: Belknap Press of Harvard University Press, 1986). 
Barak concluded that the Knesset has constituent power, which was transferred to it from the 1949 Constituent Assembly. Views and statements of politicians and political parties, academic writings, and judicial treatment of constitutional questions, Barak asserted, support this position. The other majority Justices agreed by and large with Barak's approach. The outgoing Chief Justice, Meyer Shamgar, agreed that the basic laws have a constitutional status, but found that the basis for this assertion is the sovereignty of the Knesset which can, if it so desires, limit its future powers. ${ }^{34}$ Justice Chechin, the lone dissenter, argued that the Knesset has no constituent power. This power was only in the hands of the Constituent Assembly and did not pass to subsequent Knessets. ${ }^{35} \mathrm{~A}$ constitution, he explained, should be adopted in a manner that involves the people and deviates from the way regular legislation is enacted. "And the people, where is it? Is it not appropriate to approach the people and ask its opinion?", Chechin wondered. ${ }^{36}$

Since the release of the Bank Mirrabi decision in 1995, the courts have treated the basic laws as a constitution, albeit a partial one. The Supreme Court has produced a massive body of case law deriving new rights from the rights mentioned in both basic laws, and developing new doctrines of interpretation and tests for proportionality. ${ }^{37}$ Another important development that the new basic laws have ushered in was a renewed interest in the definition of the state as Jewish and democratic since both basic laws provide that their purpose is to protect rights "in order to establish in a Basic Law the values of the State of Israel as a Jewish

${ }^{34}$ Bank Mirrabi, supra note 2 at 292.

${ }^{35}$ Ibid at 484-485. Chechin's position seems to have subsequently shifted, and it seemed for a while that he accepted the principles of the constitutional revolution. Later on, in an interview after his retirement, he said that he still thinks that his position in Bank Mirrabi is the right position. See Michel Chechin, "Responses" (in Hebrew) (2007) 6 Ma'zanei Mishpat 503 at 503.

${ }^{36}$ Bank Mizrabi, supra note 2 at 519 [translated by author].

${ }^{37}$ I will elaborate more on the proportionality tests in Section 3.3 below. 
and democratic state." ${ }^{38}$ Both refer to "the spirit of the principles set forth in the Declaration of the Establishment of the State of Israel." ${ }^{, 39}$

Whether the Knesset intended to adopt a constitution and give powers to the judiciary to review its legislation has been a matter of debate since the mid-1990s. Indeed, as exemplified by the dissenting opinion in the Bank Mizrabi case, even judges disagreed. While Barak insisted that the People through the Knesset did adopt this partial constitution, others are more skeptical, and argue that it was more akin to a constitutional coup d'état than a constitutional revolution. Michel Chechin - even though it seems that he changed his mind and agreed with the majority in later decisions - reiterated his position in Bank Mizrabi after his retirement stating that

Giving constituent power to the Knesset in the decision on the Bank Mizrahi affair, I saw, and still see today, as a sort of witchcraft, alchemy at its best, the creation of something from nothing. Here we are, one day we went to sleep without a constitution, and the next day the sun woke us up and informed us that we won a constitution. ${ }^{40}$

Even avowed supporters such as Rubenstein acknowledge that the basic laws were adopted in an unorthodox way. "It is true", Rubenstein explains, "never had a parliament adopted a constitution in this way - with resistance from the Government and the Prime Minister, through a private member's bill, and in a strange atmosphere of media indifference". ${ }^{41}$ This however, does not affect the validity or constitutional status of the basic laws, and does not change the fact that they were "brought before the Knesset only after long and thorough

${ }^{38}$ Section 1A of Basic Law: Human Dignity Freedom and section 1 of Basic Law: Freedom of Occupation.

${ }^{39}$ The references to the Jewish and democratic values and the Declaration of Establishment of the State of Israel were introduced to Basic Law: Freedom of Occupation in 1994. The original text adopted in 1992 did not include those references. Only Basic Law: Human Dignity and Freedom included a reference to the Jewish and democratic state when it was first adopted in 1992.

${ }^{40}$ Chechin, supra note 35 at 503 [translated by author].

${ }^{41}$ Rubenstein, supra note 20 at 349 [translated by author]. 
negotiations between the parties in the House, and mainly between the non-religious block and the Orthodox block., ${ }^{42}$

\subsection{The Basic Laws and the Definition of the State}

Before the adoption of Basic Law: Human Dignity and Freedom in 1992, the only basic law that had a provision mentioning the Jewish character of the state was Basic Law: The Knesset, in section 7A, which, as we have seen in chapter $\mathrm{V}$, was used to police the boundaries of participation in elections. ${ }^{43}$ Basic Law: Human Dignity and Freedom, and later the new version of Basic Law: Freedom of Occupation adopted in 1994 introduced the phrase "Jewish and democratic" as the definition of the state, and since then this definition has become the official definition and a ubiquitous expression that is often used by politicians, judges and academics. $^{44}$

The inclusion of the phrase in Basic Law: Human Dignity and Freedom, however, was unplanned and a result of a compromise. The idea that Israel is and should be a Jewish state was unchallenged by all of the Zionist political parties, and there was no urgent need to have a written provision to protect it. The original bill that was the parent (or grandparent) of the basic laws (the bill for Basic Law: Basic Human Rights) included a limitation clause that stated that any violation should be "in a law that befits a democratic state". 45 This bill included a section that dealt explicitly with the right to equality. This section, like other sections on

42 Ibid [translated by author].

${ }^{43}$ The language used there was "Israel as the state of the Jewish people." It was amended in 2002 to conform to the language of the other two basic laws.

44 The phrase "Jewish and democratic" was first used in the Parties Law-1992, which was enacted days before the basic laws. While this was the first introduction of the term, the term was popularized because of the basic laws and the "constitutional revolution".

${ }^{45}$ Section 19 of the Bill. Amnon Rubenstein states that this was copied from the "Canadian Law", although s.1 of the Canadian Charter of Rights and Freedoms refers to limits on rights that are justifiable in a "free and democratic society". See Rubenstein, supra note 20 at 342. 
equality in earlier attempts to propose a constitution or a bill of rights, ${ }^{46}$ proved to be too controversial. Members of the Knesset, especially those from the religious parties, insisted on adding a special subsection that would explicitly exclude the Law of Return from the equality clause. ${ }^{47}$ The religious parties also insisted on a provision that explicitly protects discrimination as a result of the Jewish character of the state. ${ }^{48}$ One way which was suggested to avoid situating the Jewish character and the Law of Return as exceptions to - and therefore violations of - equality was to introduce a "purpose" section which explicitly states that "the rights will be respected in the spirit of the principles in the Declaration of the Establishment of the State of Israel", which includes reference to the state as a Jewish state. ${ }^{49}$ This was not enough. In order to achieve a compromise on the issue, the main supporters of the bill (mainly Rubenstein and the Chairman of the Constitution, Law and Justice Committee, Auriel Lynn) decided to split the bill into four separate bills that contain the different rights, and to forgo the equality clause because of the insistence of the religious parties on including the exception. Thus, the rights that were perceived as less controversial, such as the right to work, life, dignity and privacy were included in two separate bills that were eventually passed. Rights perceived as controversial, such as the right to freedom of speech and freedom of association, were to be included in later bills. Equality, which was the original point of contention, was out of the game. ${ }^{50}$

The compromise on equality proved to be unsatisfactory for the religious parties that feared that the advent of the basic laws on human rights would affect the character of the

\footnotetext{
46 Karp, supra note 20 at 336, n 44-48.

47 Ibid at 336; Rubenstein, supra note 20 at 341.

${ }^{48} \mathrm{Karp}$, ibid at 337; Rubenstein, ibid note 20 at 342.

${ }^{49}$ Karp, ibid at 341.

50 Rubenstein, supra note 20 at 340.
} 
state, and more precisely, their interests and the relationship between the state and religion. As a compromise, the phrase which defines the state as "Jewish and democratic" was added to Basic Law: Human Dignity and Freedom, and since then it was introduced in other laws and basic laws. ${ }^{51}$ To further alleviate the fears of the religious parties that these basic laws would not affect the religious status quo, a provision was added to Basic Law: Human Dignity and Freedom that restricted the applicability of the basic law to legislation enacted after the basic law entered into force. For Basic Law: Freedom of Occupation, this provision was limited to two years after the adoption of the basic law. ${ }^{52}$ Another provision that was introduced to the two basic laws in a later amendment in 1994, was a new section (section 1) which provided that the "rights shall be upheld in the spirit of the principles set forth in the Declaration of the Establishment of the State of Israel." The impetus for this addition was the fear of the National Religious Party (MAFDAL) that without reference to the principles of the Declaration, which explicitly mention Zionism and the right of "return" for Jews, a day may come when the Supreme Court would be inclined to invalidate the Law of Return. Rubenstein observes that while this fear is far from being justified, the amendment added more support to equality since equality was mentioned in the Declaration. ${ }^{53}$

\subsection{The Basic Laws and the People}

Following the general theme of the dissertation and the particular topic of this chapter, it is necessary to elaborate on Justice Chechin's question ("and the people? Where is it?"), and before this, ask "and the people? Who is it?". According to Barak's leading opinion

${ }^{51}$ Rubenstein, supra note 20 at 342-343. The "Jewish and democratic" definition was introduced to Basic Law: Freedom of Occupation in 1994.

${ }^{52}$ Section 10 of Basic Law: Human Dignity and Freedom; section 6 of Basic Law: Freedom of Occupation; and section 10 of the new version of the Basic Law: Freedom of Occupation.

${ }^{53}$ Rubenstein, supra note 20 at 341. 
in Bank Mizrabi, the Knesset was acting on behalf of the People and using constituent power. As debates on the constituent power question in the case law and academia make clear, an important question in this context is "who is included in the People?". It is useful therefore to highlight some aspects related to the adoption of the basic laws and the discourse on those basic laws.

As discussed in chapter $\mathrm{V}$, the right to participate in the elections for the Knesset is limited by section 7A of Basic Law: The Knesset which was first enacted in 1985. By restricting access to and representation in the Knesset to those who recognize "Israel as the state of the Jewish people" as the formulation in section 7A put it then, the composition of the Knesset as a constituent body is affected. The Knesset itself at the time had fifteen different parties represented. One of those was considered an Arab party, represented by one member. Two parties, the Progressive List for Peace (one Palestinian member) and the Progressive Front for Peace and Equality (essentially the Israeli Communist Party - four members) were joint ArabJewish parties. Three Arab members were representatives of Zionist parties (Labour and MAPAM).${ }^{54}$ Basic Law: Human Dignity and Freedom was adopted in the third reading with 32 voting in favor and 23 against. No breakdown of the vote is available. ${ }^{55}$ Rubenstein however mentions that in the second and third readings, four Arab Members voted in favor of the Basic Law and they did not oppose the "Jewish and democratic" definition. Two of those he mentions were representatives of Labour and MAPAM. ${ }^{56}$

54 "Elections to the Twelfth Knesset" (1 November, 1988), online: The Knesset, <http://www.knesset.gov.il/description/eng/eng mimshal res12.htm>.

${ }_{55}^{5}$ The records show the final tally of the votes only. See Devrei HaKnesset, 16-18 March 1992, 24, at 3793.

${ }^{56}$ Rubenstein mentions that Hashim Mahameed and Mohammad Nafa' (Progressive Front for Peace and Equality) and Saleh Tareef (Labour) and Huseein Faris (MAPAM). Rubenstein, supra note 20 at 343. An argument could be made that the Arab members of Knesset did not opposed the "Jewish and democratic" formulation when it was added to Basic Law: Freedom of Occupation in 1994. Again, there is no breakdown of the 
Irrespective of the composition of the Knesset or the identity and political affiliation of those who voted in favor, an examination of the debates that accompanied and ensued after the introduction of the basic laws may prove to be more illuminating. Almost all of the debates among the Justices in Bank Mizrabi and in the academic literature after the adoption of the basic laws ignored the fact that the basic laws, which are now officially the partial constitution, define the state in a manner that excludes, or at least ignores, a significant number of the citizens. There were vibrant debates on the question of whether the Knesset has the power to adopt a constitution, whether there was enough public debate prior to the adoption of the basic laws, and whether the courts should have the power to invalidate legislation. But on whether the Jewish and democratic definition of the state enjoys wide acceptance among all sections of the population, with some exceptions, there was very little debate. ${ }^{57}$ Even Rubenstein's article where he mentions that this formulation was not rejected by the Arab MKs was published at a later stage when there was growing resistance to the definition in critical scholarship.

The Justices in Bank Mizrabi were not any more sensitive to this issue. Barak for example, who wrote the leading opinion in Bank Mizrabi, was at pains to demonstrate the widespread acceptance of the new basic laws through the three models he suggested, but he did not have anything to say about whether this broad acceptance included the Palestinian

votes on the 1994 re-enactment of Basic Law: Freedom of Occupation. But 78 voted in favor, and two against (Devrei HaKnesset, 7-9 March 1994, 22, at 5410). It is possible that among those who voted in favor are Arab members. However, this was at a time when the definition did not attract much attention and its implications were not very clear.

${ }^{57}$ Some exceptions to this trend could be Avigdor Feldman, "The Democratic State versus the Jewish State: Space with no Places, Time with no Duration" (in Hebrew) (2005) 19 Iyunei Mishpat 717. Ruth Gavison was one of the first authors to identify some of the problematic aspects of the definition, though her approach focused on legitimizing them. See, Ruth Gavison, "A Jewish and Democratic State: Political Identity, Ideology and Law" (in Hebrew) (1995) 19 Iyunei Mishpat 631. 
citizens. He demonstrated that there was a broad acceptance of the idea that the Knesset has constituent powers based on "constitutional facts" that include constitutional continuity (that the Knesset has the constituent powers according to the basic norm), self-perception of the Knesset (based on platforms of political parties and bills and debates in the Knesset), the ideas of authors especially those who belong to the legal community, and the case law of the Supreme Court. ${ }^{58}$ Barak examined thirty pages of "constitutional facts". ${ }^{59}$ Nowhere in his review did he mention the fact that a significant minority of the citizenry is not Jewish, and may demand a measure of recognition. Nonetheless, Barak reached the conclusion that "the framework of our national life, our national experience... is that the Knesset is perceived in the national consciousness as the body that is authorized to give a constitution to Israel." This "constituent power of the Knesset is always in the hands of the people... A constitution is an act of the people that creates the regime. The people decides - according to its social conceptions in its history - who has the supreme authority in the state, and what is the rule to recognize it." ${ }^{\prime 61}$ The only time Barak acknowledged that there may be disagreement is when he discussed the content of the constitution. "On this issue", he said, "a national agreement is of course required. This agreement found its expression in the enactment of the basic laws. The Court has to give force to this agreement." ${ }^{62}$ The "national agreement" here seems to be intraJewish, for Barak's nation and national consciousness encompasses Jewish actors only. On the issue of the meaning of the definition, Barak was succinct and explained that the term

\footnotetext{
${ }^{58}$ Bank Mizrabi, supra note 2 at 359.

59 Ibid at 359-390.

60 Ibid at 390 [translated by author].

${ }^{61}$ Ibid at 391 [translated by author].

${ }^{62}$ Ibid at 400 [translated by author].
} 
"Jewish" should be understood in its "Jewish heritage sense and Zionist sense". ${ }^{63} \mathrm{He}$ emphasized that "[i]ndeed, we are different than the world's nations. We are not a democratic state only, but a Jewish state as well." ${ }^{64}$

Nothing, however, shows more clearly that the debate was indeed an intra-Jewish debate than accounts of the different forces and blocks acting in favor or against the adoption of the basic laws. Almost all of the negotiations were characterized as between the Orthodox block and the non-religious block. ${ }^{65}$ Most accounts present the outcome as a compromise among the different groups within society to promote human rights and at the same time maintain the status quo in terms of religious arrangements. More critical assessments highlighted other factors, such as attempts by old elites to maintain hegemony or attempts by business-friendly forces to accelerate the rate of economic liberalization. ${ }^{66}$ The Palestinian citizens, as a distinctive minority group that is not likely to agree to the definition, were never seen as a relevant party. While this could be attributed to their underrepresentation in the Knesset, and the fact that at that time there was no real "Arab block" that could be a credible party to negotiations, still, this is a strong indication of who was considered part of the People whose consent was necessary. ${ }^{67}$

While the forgoing discussion of the relationship between the idea of the People and the definition of the state is based on observations and conclusions that leave some room for speculation, especially given the underrepresentation of Palestinians in the Knesset,

\footnotetext{
${ }^{63}$ Ibid at 434 [translated by author].

${ }^{64}$ Ibid [translated by author].

${ }^{65}$ Rubenstein, supra note 20; Karp, supra note 20; Hana Lerner, supra note 12.

${ }^{60}$ Shafir \& Peled, surpa note 11; Hirschl, supra note 11; Ran Hirschl, "The 'Constitutional Revolution' and the Emergence of a New Economic Order in Israel” (1997) 2 Israel Studies 136.

67 At the time, there were 7 Arab MKs in total, 3 belonging to Zionist parties, and 2 to the Communist Party.
} 
subsequent developments, related to the power to amend the basic laws, helped clarify the scope of constituent power, the sovereignty of the people, and who the People is.

\subsection{Constitutional Amendments and the Definition of the State}

The peculiar way in which the basic laws became the constitution of Israel may leave many questions unanswered regarding who really holds constituent power in Israel. It is clear that the Knesset is the body that adopted them and that the Court declared them constitutional based on the two hats theory, which, as Barak explained, allows the Knesset to use constituent power that is based on the sovereignty of the People. This description however is weakened by the fact that the basic laws were adopted using the same procedures as regular legislation, and that some MKs involved had no idea they were approving a constitution, and some even felt they were deceived into agreeing to it. ${ }^{68}$ Further diminishing this model was the split court decision on this significant question. The fact that the majority of the People knew that it had adopted a constitution only after the fact also does not provide much support. Today, 15-20 years after the onset of the constitutional revolution, authors are still writing to defend or attack it, and many still have doubts about the constituent power of the Knesset. ${ }^{69}$

Another ambiguity is the way the term constituent power is used in the case law and the academic debates. The term is used in a technical sense as the body that has the powers to create a constitution. Even though it is always imputed to the People, the manner in which the term is used deprives it of one of its main characteristics as discussed in the theoretical literature, that is, its power to transform the already constituted power of the state in the form

\footnotetext{
${ }^{68}$ Sapir, "Constitutional Revolutions", supra note 23 at 366-371.

${ }^{69}$ Chechin, supra note 35. See also Sapir, "Constitutional Revolution in Israel", supra note 18.
} 
of existing institutions and laws. What we saw was that the constituted institutions of the state (the parliament and the Supreme Court) acted to rework the system in the name of the People. While this move did have an immense impact on the legal system as a whole, it was neither external to the constituted form, nor political (as distinguished from legal), and sought forms of legitimization that are internal to the system. This use of the term is very technical and diminishes the radical democratic potential in it. This may be the result of the influence of English public law where the idea of constituent power is largely ignored, and American constitutional law where the idea is subsumed under other categories such as popular sovereignty but is left with almost no practical function. Only one writer, Claude Klein, attempted to theorize the constitutional revolution using constituent power. ${ }^{70}$ Klein argued that when the Knesset enacts a new basic law dealing with a new issue, it exercises pouvoir constituent originaire (original constituent power), and when it amends an existing basic law, it exercises pouvoir constituent instituté (derived constituent power - or amending power). The latter form of constituent power is limited in its scope compared to the former. ${ }^{71}$

Generally, the process of constitutional amendment can help shed more light on constituent power, sovereignty and who is included in the People. Amendment rules, principles and procedures are helpful in examining constituent power since they identify the

\footnotetext{
${ }^{70} \mathrm{It}$ is perhaps not a coincidence that it was Klein who used constituent power in theorizing the constitutional revolution. Klein is originally from France. He received most of his education in France, and immigrated to Israel as an established scholar of French public law.

71 See Claude Klein, "Basic Law: Human Dignity and Freedom: An Initial Normative Assessment" (in Hebrew) (1993) 1 HaMishpat 123. Claude Klein, "After the Bank Mizrabi Decision: Constituent Power Through the Mirror of the Supreme Court" (in Hebrew) (1997) 28 Mishpatim 341. See also his earlier writing on the issue of constituent power, Cluade Klein, "Constituent Power in Israel" (1969-1970) (in Hebrew) 2 Mishpatim 51; Claude Klein, "Is There a Need for an Amending Power Theory?" (1978) 12 Israel Law Review 203.
} 
ultimate locus of sovereignty. ${ }^{72}$ Some constitutions for example have "eternity clauses" that ban the amendment of some articles or principles of the constitution. ${ }^{73}$ Those are usually the principles that are most important for the political community and political order. What do the amendment rules in Israel tell us? What are the most important principles for the People? Based on this examination, who is the People?

In Bank Mizrabi, the Supreme Court did not just confirm the constitutional status of the basic laws and declare them constitutional. The leading opinion of Justice Barak also laid down some rules regarding the amendment of basic laws. Since the Court found the basic laws to have a higher status than regular legislation, it also decided - contrary to past practice that basic laws could be amended by basic laws only. Under the "two hats" theory, the Knesset can amend a basic law while exercising constituent power, and not by using its legislative authority. As such, "regular" legislation, cannot amend "constitutional" basic laws because of its inferiority in the normative hierarchy. ${ }^{74}$ Apart from this judicially introduced requirement, there are no specific provisions in any basic law, regular legislation or the Knesset's Rules of Procedures that deal with the enactment or amendment of basic laws as such. The same rules and procedures that apply for regular legislation apply to basic laws. Unless there is a special majority clause, no special majority or special quorum is required, and indeed, as in the case of Basic Law: Freedom of Occupation, a handful of MKs could adopt or amend a

\footnotetext{
72 Sujit Choudhry, "Old Imperial Dilemmas and the New Nation-Building: Constitutive Constitutional Politics in Multinational Polities" (2005) 37 Connecticut Law Review 933 at 939. See also, Richard Alberts, "Nonconstitutional Amendments" (2009) 22 Canadian Journal of Law and Jurisprudence 5 at 6.

${ }^{73}$ For example, Article 89 of the French Constitution provides that "The republican form of government shall not be the object of any amendment." Article 79(3) of the German Basic Law declares amendments to the principles laid out in Articles 1 and 20 inadmissible. These principles include human dignity, democracy, superiority of the constitution order and the right to resist attempts to overthrow the constitutional order.

${ }^{74}$ Bank Mizrahi, supra note 2 at 406-407. Barak expressed this position in his article declaring the constitutional revolution, see Aharon Barak, "The Constitutional Revolution", supra note 25.
} 
basic law. According to the existing arrangements, therefore, the Knesset, representing the People, is all powerful and can exercise constituent power as it wishes. However, this power is tempered by some rules that the Supreme Court has introduced in the case law.

The issue of the limits on the powers of the Knesset as a constituent body has arisen a number of times in the jurisprudence of the Supreme Court. ${ }^{75}$ The discussions, almost all of them obiter dicta and incidental to the matters discussed, reflect an inclination among the Justices that the Knesset is not omnipotent when acting in its constituent capacity, and that there are some principles that limit its powers. The most pronounced limitation discussed in the case law relates to Israel's definition as a Jewish and democratic state. In the Academic Centre for Law and Business v. Minister of Finance case, in explaining the limits on the legislative and constituent powers of the Knesset, Justice Barak stated that

there is room for the view that a statute or a basic law that negates the character of Israel as a Jewish and democratic state is not constitutional. The people, the sovereign, did not authorize our Knesset to do so. The Knesset was authorized to act within the framework of the basic principles of the regime. It was not authorized to annul them. This case before us does not fall within that narrow frame. ${ }^{76}$

The Knesset, therefore, cannot change or annul the democratic character of the state, nor can it change the Jewish character or even "the minimum requirements of that character", which include the basic ingredients of Zionism as a political ideology. ${ }^{77}$ This position essentially

${ }^{75}$ Bank Mizrahi, supra note 2; HCJ 6427/02 The Movement for the Quality of Governance in Israel v. The Knesset (2006) [Movement for the Quality of Governance]; HCJ 4908/10 Bar-On v. The Knesset (2010) [Bar-on].

${ }_{76}$ Movement for the Quality of Governance, ibid at para. 74. (opinion of Chief Justice Barak).

${ }^{77}$ Aharon Barak, "Unconstitutional Constitutional Amendments" (2011) 44 Israel Law Review, 321 at 340 [Barak, "Unconstitutional"]. Chief Justice Beinisch quoted extensively (and approvingly) from the Hebrew version of this article in a later decision. See Bar-on, supra note 75 at paras. 31-35 (Chief Justice Beinisch opinion). These components, as discussed in the Tibi case include "a Zionist perspective and a traditional perspective at the same time... At their center stands the right of every Jew to make aliya to the State of Israel, that in Israel Jews will be a majority, Hebrew will be the main official language of the state, and its main holidays and symbols reflect the national emergence of the Jewish people, the heritage of Israel is a central component of the state's 
creates an unwritten "eternality" clause in the constitutional edifice that enshrines the Jewish and democratic definition. ${ }^{78}$ Barak and his successor as Chief Justice, Dorit Beinisch, situated this position in the doctrine of "unconstitutional constitutional amendment", which they cautiously accepted and adopted. They found that this doctrine is accepted in many jurisdictions around the world and they both referred to comparative literature on the issue. They qualified their position explaining that the situation in Israel is not fully ripe for the doctrine's application in a broad manner; since the constitution is still evolving, the doctrine should only be applied in a narrow manner and be limited to the fundamental principles of the legal system, primarily the Jewish and democratic character of the state. ${ }^{79}$

Situating this position on the eternity of the "Jewish and democratic" definition in comparative literature is in one sense misleading. ${ }^{80}$ Most of the cases of unconstitutional constitutional amendments that Barak reviews focus on universal principles such as democracy and human dignity. Some refer to broader principles like "the basic structure of the constitution" as in India, but none of them are as particular as the Jewish definition. More importantly, even though this protection also extends to the democratic character, this position means that the Jewish definition, which cannot be changed democratically, in essence trumps the democratic character. The Jewish character is not a matter of democratic

religious and cultural heritage." EC 11280/02 Central Elections Committee for the Sixteenth Knesset v Tibi, IsrSC 57(4) 1 at 22 [Tibi] [translated by author].

${ }^{78}$ Sharon Weintal, "The Challenge of Reconciling Constitutional Eternity Clauses with Popular Sovereignty: Toward Three-Track Democracy in Israel as a Universal Holistic Constitutional System and Theory" (2011) 44 Israel Law Review 449 at 463.

79 Bar-on, supra note 75 at paras 33-34; Barak, "Unconstitutional", supra note 77 at $340-341$.

${ }^{80}$ Barak examines the doctrine as applied in Turkey, India, Austria, Germany, US, Ireland and Brazil. 
agreement, but an axiomatic given that even democracy, in its narrow sense (majority rule) or its broader sense (majority rule and human rights) cannot change or question. ${ }^{81}$

A scenario where the Knesset decides to change the definition of the state and change the Jewish character is of course an almost impossible scenario, given the composition of the Knesset, the restrictions imposed on the candidates, and because of procedural obstacles related to the internal procedures of the Knesset that will be discussed in the next section. Similarly, a situation whereby such a change is possible in a democratic way will inevitably be preceded by fundamental changes to the state and the society. But the fact that this almost impossible scenario is presented as an unconstitutional constitutional amendment gives a strong indication about how deeply entrenched and all-encompassing the Jewish definition is to the constitutional order. More importantly, it raises many questions about the sovereign people that holds constituent powers. In this case, the People, or whoever is acting on its behalf, is not only bound by democracy, but also by a commitment to uphold the Jewish nature of the state that trumps democracy. The ultimate locus of sovereignty in this case, therefore, is not the People seen as the citizenry, but a different collective that believes in the Jewish definition and its minimum requirements.

\footnotetext{
81 Sharon Weintal acknowledges the problem in entrenching particular values (the Jewish character in the case of Israel) and proposes a three track democracy where decision making process is divided to three tracks: normal politics, constitutional politics, and revolutionary constitutional politics. He suggests that entrenched particular values should not be immune to challenge and change in the third track. On the particular case of Israel's definition, Weintal argues that according to his model,

[t]he democratic nature of the state, as a universal founding value, is clearly off the table for all three tracks. However, the Jewish element, which is mistakenly regarded as its conjoined twin, actually possesses the lower normative status of a particular founding value. As such, the Jewish nature of the state is exposed to potential future operation of the third track, a negotiable issue for an (as yet) unknown constitutional organ (not the Knesset) that is capable of serving as an organ of the nation and claiming its right to break out of the founding narrative by drafting a broad historic compromise as a new constitution for a new Israel to be submitted for ratification by communal referendums.
}

Weintal, supra note 78 at 497. 


\section{Making Law: The Jewish and Democratic Definition of the State and Legislation}

Legislation, or law-making, is one of the most important functions of the state. In a parliamentary system, legislation is the most important means of governance. Like all other aspects, the Jewish and democratic definition affects the process of legislation, its interpretation and review. This will be the focus of this section.

\subsection{Making Law: The Knesset's Rules of Procedure}

The Knesset is the legislative authority of the state. Only the Knesset can make primary legislation. Secondary legislation can be enacted only based on explicit authorization in the primary legislation. The work of the Knesset is mainly regulated by Basic Law: The Knesset and the Knesset Law-1994. The basic law contains provisions about the powers of the Knesset, election of its members, suspension or resignation of members, and other details. The Knesset Law -1994 provides more details about the work of the Knesset, focusing on the role of the Presidium, the different committees and the Head of the Opposition. Section 19 of the basic law authorizes the Knesset to adopt Rules of Procedures (Takanon HaKnesst, in Hebrew) to determine its internal procedures. The Rules of Procedures are included in a long and comprehensive document that deals with all of the procedures of the Knesset relating to all its functions. The Rules of Procedures are adopted (and could be amended) by a simple majority in the Knesset (Art. 145).

The Rules, although adopted by the Knesset, are at a lower level in the normative hierarchy than legislation. ${ }^{82}$ The Knesset is obliged to follow the Rules, and is not allowed to deviate from them. The Supreme Court has ruled on several occasions that a deviation from

\footnotetext{
${ }^{82} \mathrm{HCJ}$ 669/85 Kabane v. Speaker of the Knesset (1985), IsrSC 30(4)393 at 399 (in Hebrew) [Kabane].
} 
the Rules is a defect that might (but not necessarily) affect the validity of the legislation. ${ }^{83}$ The Court is authorized to (and does) review the work of the Knesset, including the content of the Rules of Procedures, but is generally reluctant to use a power which could be seen as an interference with the privileges of the legislature. Judicial review of the Rules is usually limited to "circumstances that are extreme in their character," when "a material defect that affects the roots of the fundamental principles of our constitutional regime and our democratic perception" is found in the Rules. ${ }^{84}$

The definition of the state (or a variation thereof) plays a role in the legislative process through the Rules. Section 75(e) (formerly section 134) of the Rules of Procedures provides that "[a] private members' bill shall be brought for the approval of the Knesset Presidium. The Knesset Presidium shall not approve a bill that in its opinion denies the existence of the State of Israel as the state of the Jewish People, or is racist in its essence." 85 The story of the introduction of this section is similar to the story of section 7A of Basic Law: The Knesset. After Kahane's election to the Knesset in 1984, he initiated private member bills that were extremely racist. These included proposals to limit citizenship to Jews only; to determine the legal status of non-Jews according to Jewish law including the imposition of special taxes on, and even the enslavement of non-Jews; to prohibit non-Jews from living in Jerusalem; to ban any joint Jewish-Arab activities; to create separate beaches; and to ban marriage or even relationships between Jews and non-Jews. ${ }^{86}$ The Knesset Presidium, which comprises the Speaker of the Knesset and his/her Deputies, did not approve those bills for debate before

\footnotetext{
${ }^{83}$ HCJ 5131/03 Litzman v Speaker of the Knesset (2005), IsrSC 59(1) 577 at 590. HCJ 975/89 Nimrodi Land Development Ltd. $v$ Speaker of the Knesset (1991), IsrSC 45(3) 154 at 157 (in Hebrew).

${ }^{84}$ Kahane, supra note 82 at 399 [translated by author].

${ }^{85}$ Translation of the Knesset website, supra note 3.

${ }^{86} \mathrm{HCJ} 742 / 84$ Kabane v. Speaker of the Knesset (1985), IsrSC 29(4) 85 at 88 (in Hebrew).
} 
the Knesset. Kahane petitioned the Supreme Court. The Court accepted his petition, and noted that absent a provision in the Rules, the Knesset cannot reject bills based on their content. ${ }^{87}$ Heeding this comment by the Court, the Knesset introduced what is now section 75(2). A petition challenging the section was rejected in 1985 stating that the Knesset was acting within its powers under the basic law and that the Court can only interfere in the most severe situations. ${ }^{88}$

Section 75(e) was used a number of times to block private members bills. In 1997 it was used to block a bill that stated that only a Jew could be Prime Minister, and in 2004 it was used to block a bill that mandated any evacuation of Jewish settlements in the occupied Golan Heights will be accompanied with the removal of the same number of Arab towns in Israel. ${ }^{89}$ In addition to the bill by Kahane, those were the most extreme bills that the Knesset Presidium blocked. Still, some equally racist bills were allowed to proceed, such as a bill that sought to promote the emigration of Palestinian citizens to Arab states through economic incentives. ${ }^{90}$ More recently, there has been an increase in the number of bills that have not been approved by the Presidium under this Section because they were seen as negating the Jewish nature of the state even though they did not contain explicit negation of that element. Most notable among those cases is the bill that proposed to amend a section in the Foundations of Budget Law-1985. The section at issue gives powers to the Minister of Finance to decrease funds transferred to any publicly funded body that makes any expenditure that is seen, inter

${ }^{87}$ Ibid.

${ }^{88}$ Kahane, supra note 82.

${ }^{89}$ Shourick Dreishfitz, "Knesset Presidium" (in Hebrew) (September 2010) 66 Parliament, online: The Israel

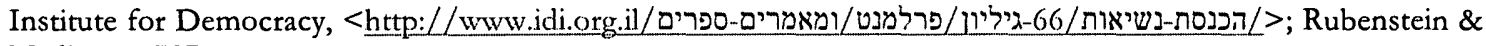
Medina, at 737.

${ }^{90}$ Gideon Alon, "The 'Encouragement of Emigration for Arabs' Law was Approved for Initial Reading”, Haaertz (18 February 2002), online: <http://www.haaretz.co.il/misc/1.772914>. 
alia, as a negation of the definition of the state or marks Independence Day as a day of mourning. The bill proposed to add "the public denial of the Nakba as a historic, real and constitutive event for the Palestinian people, including the Arab minority in Israel, or an action with the intention to deny the feeling of being at home, ownership over, and full equality in the State of Israel." ${ }^{\text {91 }}$ Despite an opinion by the Knesset's legal advisor stating that the bill does not violate section 75(2), the bill was rejected by the Presidium in a split vote. The initiator, MK Ahmad Tibi, petitioned the Supreme Court against this decision. The Court, after deciding to discuss the petition before a panel of seven judges, dismissed it without prejudice on the grounds that with the new elections in 2013, the Knesset Presidium of the 18th Knesset no longer exists, and the new $\left(19^{\text {th }}\right)$ Knesset will have a new Presidium which will be a different body. ${ }^{92}$ In essence, the Court decided to avoid the question. The same Presidium rejected two other bills by the same MK based on the same grounds. ${ }^{93}$

The Knesset Presidium is a purely political body, and the use of section 75(e) reflects the political positions in the Knesset. The outcome very much depends on the individuals involved and their political beliefs. They do not have to justify their positions even though in some cases the decision adopted by the Presidium is contrary to the position of the legal advisor, as in the case of the bills proposed by MK Ahmad Tibi. On the other hand, in another case, the Presidium approved a bill despite the position of the legal advisor that it

\footnotetext{
${ }^{91}$ A bill amending the Foundations of Budget Law (Nakba Denial Amendment) -2011.

92 HCJ 5478/11 Tibi v. Speaker of the Knesset (2013) (unpublished).

${ }^{93}$ One of the bills, Al-Quds the Capital of Palestine, was intended, according to its proponent, MK Ahmad Tibi, to emphasize the importance of Jerusalem for Palestinians and Muslims. The second one, which proposed an amendment to the Public Education Law, sought to stop the characterization of Palestinian fighters in the pre-state period as "gangs". The position of the legal advisor of the Knesset was that the former bill does seek to undermine the existence of Israel as state of the Jewish people, the latter bill, however, does not. See "Announcement by the Knesset Spokesperson" (15 January 2012), online: The Knesset <http://www.knesset.gov.il/spokesman/heb/Result.asp?HodID=9579>.
} 
negates the Jewish character of the state. The bill, Basic Law: Equality of the Arab Population, which was proposed in 2000 , included a provision that characterizes Israel as a "democratic and multicultural state" as opposed to a Jewish state, which brought it within the purview of section 75(e) according to the opinion of the legal advisor of the Knesset. ${ }^{94}$

The Jewish and democratic definition of the state is not only relevant to the legislative process. A Member of the Knesset, according to the "General Principles" section of the Rules of Procedures, "shall fulfill his position out of loyalty to the fundamental principles of the State of Israel as a Jewish and democratic state" [Section 1A(1)]. A Members of Knesset lobby group shall not be allowed to function if its goals or activities, explicitly or implicitly, include "the denial of the existence of the State of Israel as a Jewish and democratic State" [section $138(\mathrm{~g})(1)]$

While the Rules of Procedure are not on the same normative level as legislation or basic laws, they are, nonetheless, part of the broader constitutional order that sets the limits to what kind of legislation can even be debated, let alone enacted. ${ }^{95}$ While these arrangements can be changed by a simple majority of MKs, the existence of a provision like section $75(\mathrm{e})$ functions as a further obstacle that would block any legislative proposal from being debated if it does not conform to the Jewishness of the state. Even (futile) attempts to make any change, minor as they may be, could be blocked. The recent cases of the Presidium blocking bills and the Court's reluctance to interfere indicate that this section may be used more frequently in the future.

94 Dreishfitz, supra note 89.

${ }^{95}$ Ariel Bendor contends that the Supreme Court has elevated the Rules of Procedures to the level of a constitution by allowing limitations on the political content of bills. Bendor sees this situation as problematic. Ariel Bendor, "The Constitutional Status of the Rules of Procedures of the Knesset" (in Hebrew) (1994) 22 Mishpatim 571. 


\subsection{Interpreting Law: The Jewish and Democratic Values and Statutory Interpretation}

Interpretation of legal texts is one of the most important functions of the judiciary. The process of interpretation gives meaning to the text; it is so integral to law that Ronald Dworkin argues that "legal practice is an exercise in interpretation." definition of the state as a Jewish and democratic state play in the interpretation process?

The leading interpretative approach in the Israeli legal system is the purposive approach. This approach emphasizes the purpose or purposes that the legal text aims to achieve. Generally, it is assumed that there are general purposes, which include the "fundamental principles of the system", and specific purposes. As part of the "fundamental principles", the Jewish and democratic values of the state are part of the general purposes that legal texts aim to achieve. ${ }^{97}$ As such, there is a presumption that "every law of the Knesset or order by the Government are meant to fulfill Israel's values as a Jewish and democratic state." 98 This approach, in a sense, opens the door to introducing the Jewish and democratic definition into almost any legal document, including statutes. While there has not been much discussion of these presumptions, and I am not aware of any decisions where the definition played a decisive role, the potential exists for the definition to affect legislation in a manner that promotes the Jewish character of the state (and its components) even if it is not mentioned in the text. One example is the General Security Service Law-2002 which regulates the work of the secret service (the GSS, known in Hebrew as the SHABAK). According to section 7 (a) of the law, the GSS is in charge of protecting "state security and the order and

${ }^{96}$ Ronald Dworkin, "Law as Interpretation" (1982) 9(1) Critical Inquiry 179 at 179.

${ }^{97}$ HCJ 5016/96 Horev v. Minister of Transport (1997), IsrSC 51(4) 1 at 43 (in Hebrew) [Horev].

${ }^{98}$ Aharon Barak, $A$ Judge in a Democratic Society (in Hebrew) (Jerusalem: Nevo, 2004) at 89 [translated by author] [Barak, "A Judge"]. 
institutions of the democratic regime against threats of terrorism, sabotage, subversion, espionage and disclosure of State secrets, and the Service shall also act to safeguard and promote other State interests vital for national State security...”. The GSS and the Attorney General interpret this provision to include protection against attempts to change the Jewish or democratic character of the state. Such attempts are seen as "subversive" and justify taking surveillance and enforcement measures against the perpetrators. This interpretation is based on the understanding that the GSS is an administrative unit that is part of the Jewish and democratic state. ${ }^{99}$

As part of the values of the state as a Jewish and democratic state, Jewish law also plays a role in interpretation. ${ }^{100}$ This role is augmented by section 1 of the Foundations of Law Act-1980 which stipulates that "[w]here the court, faced with a legal question requiring decision, finds no answer to it in statute law or case-law or by analogy, it shall decide it in the light of the principles of freedom, justice, equity and peace of Israel's ${ }^{101}$ heritage." There was a long debate on the proper interpretation of this requirement with some, such as former Deputy Chief Justice Menachem Elon, arguing for a direct and broader use of Jewish law, and others, such as Barak, reserving it to situations of lacunae and then only to the principles of "freedom, justice, equity and peace". ${ }^{102}$ But even Barak agrees that Jewish law should provide "interpretative inspiration" 103 since the "fundamental principles of the Jewish law shape our

${ }^{99}$ Letter from the Attorney General's Office to Adalah (20 May 2007), in Adalah Newsletter (May 2007$) 36$ online: <http://www.adalah.org/newsletter/eng/may07/5.php> (in Hebrew).

100 Barak, "A Judge", supra note 98 at 91.

101 The word Israel here means the Jewish people. Israel's heritage, therefore, means Jewish heritage.

102 See the debate between Justice Menachem Elon and Justice Aharon Barak in FH 13/80 Hendles v. Bank Koopat HaAam Ltd. (1981), IsrSC 35(2) 785 (in Hebrew); HCJ 1635/90 Jarjevski v. Prime Minister (1991), IsrSC 45 (2) 749 (in Hebrew).

${ }^{103}$ Barak, "A Judge", supra note 98 at 290, See also in English, Aharon Barak, "The Role of the Supreme Court in a Democracy" (1998) 3:2 6 at 18 [Barak, "The Role”]. 
character both as a people and as a state." ${ }^{104}$ This approach to Jewish law, Barak argues, is not religious in its nature, but "is nationalist in character", such that it is acceptable for secular people as well as religious. ${ }^{105}$ By adopting this position, Barak adopts a position that is sensitive to both groups, secular Jews and religious Jews. This sensitivity, however, seems not to extend to the Palestinian citizens who cannot really say that Jewish law "shaped their image" ${ }^{106}$ The lack of recognition and the erasure through casting the People as only the Jewish people is evident. But beyond that, while we can see that Jewish law plays a role in the interpretation of Israeli law, one can discern a practice of abandoning established legal approaches that were valid during the period before 1948 in order to use law and its strict interpretation at the expense of the Palestinian citizens especially in legal issues related to land. The prime example of these trends is the case of the Palestinian Bedouins in the Naqab (Negev) whose special rights and customs relating to land rights that were guaranteed by the British Mandate authorities were eschewed by the Israeli courts. ${ }^{107}$ On the one hand, Jewish law and heritage are an inspiration for statutory interpretation, on the other hand, existing legal principles are ignored, narrowed, and re-interpreted in cases of a clash between the state and its Palestinian citizens, especially when it comes to land. If we see law as part of the selfrule of the People, and see the role of judges as interpreting and applying law based on the

\footnotetext{
104 Ibid.

105 Barak, "A Judge", supra note 98 at 289.

106 Although, writing elsewhere in English, Barak stated that "[o]ur existence as a state containing a non- Jewish minority entitled to full equality reflects our state of being. The fundamental values on which the culture and tradition of this non-Jewish minority is founded constitutes part of our complete national experience. The judge gives expression to these fundamental social concepts of the nation." Barak, "The Role", supra note 103 at 11. This position however did not find any practical expression in his other writings and his judicial opinions.

107 Ahmad Amara \& Zinaida Miller, "Unsettling Settlements: Law, Land, and Planning in the Naqab" in Ahmad Amara, Ismael Abu-Saad \& Oren Yiftachel, eds, Indigenous (In)Justice: Human Rights Law and Bedouin Arabs in the Naqab/Negev (Cambridge, MA: Harvard University Press, 2012) 69 at 84-92. See also Oren Yiftachel, Sandy Kedar \& Ahmad Amara, "Rereading the Doctrine of "the Dead Negev": Property Rights in the Bedouin Space" (in Hebrew) (2012) 14 Mishpat O Mimshal 7.
} 
principles and values that society or the People reveres, these approaches to legal interpretation raise serious questions about who is considered the People. While the conclusions about the effect on who is considered part of the People will be summarized below, in this context, law loses some of its moral authority since many will not see it as legitimately representing their democratic self-governance.

\subsection{Challenging Law: Judicial Review of Legislation and the Jewish and Democratic Definition}

The constitutional revolution of the mid-1990s ushered in significant changes to the Israeli constitutional system. The adoption of the two basic laws on human rights was construed to give the judiciary new powers to review primary legislation - powers that no state-body had hitherto exercised. Even though judicial review of legislation was not mentioned in the basic laws, they set out the mechanism for this review which is modeled after the Canadian Charter of Rights and Freedoms and the European Convention on Human Rights. ${ }^{108}$ The mechanism is set out in the "limitation clause" (section 8 of Basic Law: Human Dignity and Freedom), which stipulates that " $[\mathrm{t}]$ here shall be no infringement on rights under this Basic Law except by a law befitting the values of the State of Israel, enacted for a proper purpose, and to an extent no greater than is required or by regulation enacted by virtue of express authorization in such law." Basic Law: Freedom of Occupation has a similar "limitation clause" in section 4. The "limitation clause" is seen as

reflecting the balancing between the constitutional interests that are reflected in the basic rights, and the needs that are reflected in the impugned legislation. The basic rights -even though they are important rights with constitutional nature- are not absolute, but emerge from the reality of life that requires balancing between the obligation to protect important individual rights and addressing other valuable interests, whether of the individual or the public....The limitation clause is meant to demark the limits within which primary legislation can emerge even if it entails a violation of a basic right, but only if this violation is found within the

108 Rubenstein, supra note 20 at 342. 
appropriate range of balancing between the protection of the right and the need to achieve the other important purposes that entail the violation of the right. ${ }^{109}$

The Supreme Court devised a methodology for examining the constitutionality of legislation based on this clause. ${ }^{110}$ Since the "limitation clause" is based on the Canadian model, the Supreme Court borrowed significantly from the jurisprudence of the Supreme Court of Canada, especially the Oakes case. ${ }^{111}$ As part of the review process, an infringement on a right that is listed in the basic laws, or rights that are derived from those rights, should be established. If an infringement does exist, the next stage is to examine if it meets the conditions of the "limitation clause". The first condition is that the violation has to be by a law enacted by the Knesset, or by virtue of secondary legislation passed pursuant to legislation enacted by the Knesset. The second condition mandates that the violation should "befit the values of the State of Israel". Those are defined in section 1 as Jewish and democratic values. The third condition that the impugned legislation has to pass is the "proper purpose", where the interpreter examines the purpose or purposes of the legislation under review. The fourth condition is meant to determine that the violation of the right is to "an extent no greater than is required". This condition is also known as the proportionality condition. The case law has determined three tests to establish the proportionality of a violation. The first test is the "fit test", whereby there is a need to establish a fit between the purpose the legislation seeks to achieve and the means used. The second test, the "necessity test", examines whether there are other means that could be used to achieve similar results with a lesser violation of the right.

${ }^{109}$ CLA 3145/99 Bank Leumi Ltd. v Hazan (2003), IstSC 57(5) 385 at 405 (in Hebrew) [translated by author]. ${ }^{110}$ See e.g. Bank Mizrahi, supra note 2; HCJ 1715/97 Investment Managers Bureau v Minister of Finance (1997), IsrSC 51(4) 367 (in Hebrew); HCJ 1030/99 Oron v Speaker of the Knesset (2002), IsrSC 56(3) 640 (in Hebrew) [Oron]; Gaza Shore Regional Council, supra note 1.

111 R. v. Oakes, [1986] 1 SCR 103. 
The third test, also known as the "narrow proportionality test", examines the proportionality between the benefit or utility that arise from achieving the proper purpose of the legislation, and the degree of the infringement on the constitutional right. The focus here is on the consequences of the impugned legislation, and essentially it is a matter of balancing the benefit of achieving the proper purpose and the damage inherent in the violation of the right. The balancing exercise examines whether there is a reasonable relationship between the infringement of the right and the social advantage that arises from it.

These conditions, especially the proportionality tests, do not necessarily lead to one "right" answer, and they provide a "range of proportionality". If the impugned legislation is beyond this range, as the courts will find it to be unconstitutional. The remedy could range from a declaration of unconstitutionality without invalidating the legislation, to partial or full invalidation. The Court usually gives the Knesset the opportunity to rectify the problem by postponing the date on which the legislation becomes invalid.

The Jewish and democratic definition plays a role in the examination of the constitutionality of legislation in at least two ways, one that is direct through the "values of the state", and one that is indirect through the "proper purpose" requirement. The tests for determining whether an infringing law "befits the values of the State of Israel" as a Jewish and democratic state are not fully developed. ${ }^{112}$ The Court usually states that the Jewish values include the Zionist nature of the state and its religious heritage together with democracy in its

112 In HCJ 466/07 Galon v. The Attomey General (2012), speaking as part of the minority, Justice Levi decided that the Entry to Israel and Citizenship Law-2003 is unconstitutional, inter alia because it does not befit Israel's values. His approach was very general and vague. On the other hand, Justice Jubran (also in the minority) stated that there is no reason to get into this question in this case, especially that the case law on it is not fully developed and there are other tools to deal with the question (paras 7-8 of Jubran's opinion). Chief Justice Beinisch (also in the minority) agreed with Jubran, and stated that this particular part of the "limitation clause" will be examined in the future as the constitutional law of Israel develops (para 5). 
broad sense. ${ }^{113}$ Usually, the Jewish and democratic values are taken at a high level of abstraction, but in some cases the Supreme Court provides explanations that show how elements and values of Zionism enter into the "limitation clause". For example, in Gaza Shore Regional Council case, where the Court examined the constitutionality of the evacuation of Israeli settlers from the Gaza Strip as part of the "Disengagement Plan", the Court stated that the Jewish values include the implementation of the Zionist vision, which includes Jewish settlement. This implementation, however, "should take into consideration a combination of factors. These factors are, sometimes, derived from the Zionist aspect itself, and include national, political and security factors." 114

Others examples of the influence of Jewish and democratic values in determining the constitutionality of legislation are cases related to the Sabbath. For example, the Court ruled that legislation that bans opening businesses on the Sabbath are constitutional and befit the values of the state because the objectives behind it are social, religious and national. ${ }^{115}$ The fact that the Sabbath is important to Jews and Judaism played an important role. This observation also played an important role in a case dealing with traveling on certain roads on the Sabbath. ${ }^{116}$ But even in those cases there was no real engagement with different questions that arise and no tests could be identified.

For the "proper purpose" requirement, the case law takes into account the objective and subjective purposes and, in order to establish whether they are "proper" or not, it examines "if it [the purpose] serves important public objectives for the state and the society

113 Gaza Shore Regional Council, supra note 1 at 564; HCJ 5026/04 Design 22- Shark Deluxe Furniture Ltd v Head of the Shabath Work Permits Branch in the Ministry of Work and Welfare (2006), IsrSC 60(1) 38 at 53-54 (in Hebrew) [Design 22].

114 Gaza Shore Regional Council, supra note 1 at 565 [translated by author].

115 Design 22, supra note 113.

${ }^{116}$ Horev, supra note 97 at 43. 
for the purpose of maintaining an infrastructure for living together, and for a social framework that seeks to protect human rights and promote them."117 The social objectives should be "compatible with the values of the state, generally, and show sensitivity to human rights in a comprehensive social system."118 The examination of the "proper purpose" also takes into consideration the importance of the right: the more important the right is, the more significant the public interest justifying its violation should be. ${ }^{119}$ The Court's examination of the "proper purpose" requirement has tended to be short and very abstract. The Court had not delved deeply into the different objectives and their nature, and has usually been satisfied if the purpose of the legislation is legitimate in a general sense, as was the case with "national security" or "social policy". ${ }^{120}$ It comes as no surprise then that the Court has not found any of the many laws challenged to be lacking a "proper purpose". ${ }^{121}$

Despite the fact that the tests for determining whether the "proper purpose" and "values of the state" requirements have been met are not fully developed, still, they raise a number of issues. For example, are demographic objectives that aim to achieve a Jewish majority considered "a proper purpose" that befits Jewish and democratic values? On the one hand, the preservation of a Jewish majority is one of the most important components of the

117 HCJ 4769/95 Menachem v Minister of Transport (2002), IsrSC 57(3) 235 at 264 (in Hebrew) [translated by author]. ${ }^{118}$ Movement for the Quality of Governance, supra note 75 at para 52 (opinion of Chief Justice Barak) [translated by author].

119 Ibid at para 53 (opinion of Chief Justice Barak). See also HCJ 6893/05 Levi v Govermment of Israel (2005), IsrSC 59(2) 876 at 890 (in Hebrew); Gaza Shore Regional Council, supra note 1 at 569.

120 Barak Medina, “On the 'Infringement' on a Constitutional Right and 'Proper Purpose"' (in Hebrew) (2012) 15 Mishpat o Asakim 281 at 310. See also, Barak Medina \& Ilan Saban, "Human Rights and Taking Risks: On Democracy, 'Ethnic Profiling' and the Tests of the Limitation Clause" (in Hebrew) (2009) 39 Mishpatim 47.

121 The Court raised doubts about whether legislation under examination met the "proper purpose" requirement once only. In a challenge to an amendment to the Telecommunication Law -1982, which sought to legalize an illegal radio station associated with the far right, the Court found that there are two objectives that the legislation sought to achieve, one of which -the legalization of an illegal radio station- is not proper. The Court, however, did not make a final determination on this point and assumed it is "proper" because the legislation failed to meet the proportionality requirements and thus was declared unconstitutional on that account. See Oron, supra note 110. 
Jewish definition and as such it is likely to be seen as a proper purpose; on the other hand, it is doubtful if demographic objectives could be achieved without some form of discrimination. ${ }^{122}$ Similar questions arise especially in areas related to other components of the Jewish definition such as land settlement and housing. Although the tests are not fully developed, there are some signs that could indicate how these requirements could be interpreted. For example, in the Galon case dealing with the constitutionality of the Citizenship and Entry to Israel Law-2003, four justices expressed an inclination to accept that measures that seek to maintain Israel's Jewish majority could be considered to be a proper purpose, and befit the values of the state given that having a Jewish majority is one component of the Jewish definition. ${ }^{123}$ The state also argued that demographic considerations should be considered a "proper purpose" that befits the values of a Jewish and democratic state. ${ }^{124}$ Even Aharon Barak, who found the Citizenship and Entry to Israel Law- 2003 to be unconstitutional, stated in an interview that legislation that infringes protected human rights in immigration for the purpose of maintaining the values of the state as a Jewish state (i.e. demographic considerations) should be seen to be for a "proper purpose" and befitting the values of the state. For him, the main determination should be made at the stage of the proportionality examination. ${ }^{125}$

These signs show that the inclusion of the Jewish and democratic values as a requirement of a limitation clause, and indirectly to measure "proper purpose", could affect judicial review of legislation, especially in cases that deal with immigration, the preservation of

\footnotetext{
122 Medina and Saban see maintaining a Jewish majority as a "proper purpose", but this should also be achieved by acceptable means. See Medina and Saban, supra note 120 at 96-97.

123 See the discussion in Chapter 4.

${ }^{124}$ State's Briefings in Adalab v. Minister of Interior, (16.12.2003) as cited in HCJ 7052/03 Adalab v Minister of Interior (2006), IsrSC 61(2) 202 at para 14 of Justice Procaccia's opinion.

125Interview of Aharon Barak by Mordecai Krimintzer (2012) on Prof. Krimnitzer Hosting Prof. Barak, Third Programme, online: Israel Democarcy Institute YouTube channel <http://www.youtube.com/watch?v=VGFF9ljwQyg $>$.
} 
a Jewish majority (on the state level and regional level), or land use. The inclusion of the Jewish and democratic values in the criteria used to examine the constitutionality of legislation that potentially infringes the rights of Palestinian citizens may justify certain purposes, considerations or measures that would otherwise be more difficult to justify. This is especially pertinent in cases where there is a clash between the Jewish definition (and its nuclear characteristics) and constitutional rights. ${ }^{126}$ In these cases, the two conditions (the "proper purpose" and "befitting the values of the state") that are considered "threshold conditions" that are meant to ensure that the infringement is justified and act as "barriers" to infringement, do not fulfill their function. In fact, because of their direct relation to the Jewish definition, they function in an opposite manner, that is, they justify the infringement in a manner that might affect the proportionality analysis. This means that constitutional protection for some rights (of the Palestinian citizens) is weaker since considerations related to the definition of the state could be used to justify infringement in a manner which does not apply to Jewish citizens. In essence the definition of the state and the "proper purpose" component of the "limitation clause" relax the degree of constitutional protection given to the fundamental rights of Palestinian citizens.

One of the justifications of judicial review of legislation and the idea of constitutionalism is the protection of human rights of individuals from the excesses of the state. The underlying principle on which legislation could be invalidated is the importance and the higher normative status of the rights that are entrenched in the constitution. Constitutional supremacy and judicial review, in this sense, are "authorized" by the People and aim to protect the People understood as the citizenry. As discussed above, the role that the Jewish and

${ }^{126}$ For the nuclear components of the Jewish definition, see Tibi, supra note 77. 
democratic definition plays in the evaluation of the constitutionality of legislation, through the "limitation clause", may serve to diminish the protection that the basic laws provide to Palestinian citizens in a number of issues. This real risk of diminished protection may make possible and indeed encourage the enactment of laws that affect the rights of the Palestinian citizens. This potential for relaxed protection has implications for who is considered the People. In this sense, in its constitution, the People provided the highest degree of protection to the group that is considered the People, which is the Jewish citizens. Other citizens and residents do benefit from constitutional rights, but the degree of protection is relaxed when it comes to issues that may be in conflict with the interests of the Jewish majority. In this sense, the People are only those who enjoy the full protection of rights.

\section{The Jewish and Democratic Definition in other Legislation}

In addition to the laws and the basic laws discussed in this chapter and chapter $\mathrm{V}$, the Jewish and democratic definition can be found in a number of other statutes dealing with different issues and playing a diverse range of roles.

The definition, for example, is used in the Foundations of Budget Law-1985 (as amended in 2011) as grounds to reduce funding for publicly funded bodies. According to Section 3a, the Minister of Finance can reduce the amount of funding to a funded body if it makes any expenditure that could be seen as a negation of the existence of the state as a Jewish and democratic state [section 3a(1)]. ${ }^{127}$ Other grounds include marking Independence Day as a day of mourning [section $3 \mathrm{a}(4)$ ]. The funded bodies could include schools, local councils or

${ }^{127}$ Foundations of the Budget Law (Amendment No. 40) (Reduction of Budget or Support Because of Activity Against Principles of the State) 2011. 
community centres. This amendment was enacted with the purpose of limiting the political activities of the Palestinian citizens that challenge the definition of the state and mark the anniversary of the Nakba and specifically targets already underfunded institutions. A petition to the Supreme Court challenging the constitutionality of this law was dismissed in January of 2012 citing the "ripeness doctrine", that is, that the circumstances for examining this legislation were not ripe yet since it had not been used at that time, and there was no way to determine how the Minister would use his discretion. ${ }^{28}$ The Court ignored the petitioners' argument that the very existence of such legislation is enough to have a chilling effect on freedom of speech.

The Jewish and democratic combination was also added to a number of pieces of legislation especially those dealing with culture, arts and education. The Public Education Law 1953 was amended in 2000 to add education in the values of the Declaration of Independence and the values of the state as Jewish and Democratic state as goals of public education [section 2(2)]. At the same time, it added subsection 11 which provides that knowing the language, culture and history of the "Arab population and other population groups in the State of Israel, and to acknowledge the equal rights of all the citizens of Israel" is also a goal of the public education system. The Culture and Art Law- 2002, which creates the Israeli Council for Culture and Art, states that the promotion of Jewish and democratic values is one of its goals in section 2(c). ${ }^{129}$ In the same vein, the Broadcasting Authority Law-1965, which governs public television and radio, was amended in 2012 to add, as the first objective of public

${ }^{128}$ HCJ 3429/11 The Alumni of the Arab Orthodox High School in Haifa v. Minister of Finance (2012) (in Hebrew) (unpublished).

129 "The Council shall act to promote the culture and art policy, that gives expression to the creative and artistic life in the State of Israel, while ensuring creative freedom and giving expression to the diverse culture of the society in Israel and to the different views that prevail in it, and to its values as a Jewish and democratic." 
broadcasting, "to reinforce and to deepen the Zionist identity of the State of Israel as a Jewish and democratic state and as an aliya absorbing state" [section 3(1)]. Similarly, the law governing private television and radio stations, The Second Authority for Television and Radio Law1990 states, in section 5(b)(3), that "expressing the Jewish heritage and its values, and the values of Zionism" is one of its main goals. According to an amendment to Regulations that were promulgated based on this law, the regulator, the Second Authority for Television and Radio, has the power to ban a fundraising broadcast if "it negates the values of the State of Israel as a Jewish and democratic state." (section 13B(1) of the Second Authority for Television and Radio Regulations (Ethics in Advertisements in Radio Broadcasts)-1999).

\section{Conclusions and Summary}

An examination of the different levels of the Israeli constitutional system shows that the definition of the state is entrenched at almost all levels and plays an important role in a number of critical areas related to governance. The most important level is the area related to the basic laws and their amendments. The definition is mentioned in three basic laws where it has a functional role. This definition, and the determination that basic laws have constitutional status, was adopted without broad public discussion. Even in the discussions on the basic laws and the definition, the Palestinian citizens were not seen as a relevant party that should be part of the consensus-building process. While this raises questions about who is the People that supposedly have adopted the basic laws as a constitution, an examination of the principles that deal with constitutional amendments reveals that the entrenchment of the definition in the constitutional system is more deep-rooted. The prevailing opinion in the Supreme Court is that the Knesset, which exercises constituent power to enact basic laws, is bound by the 
authorization set out in the Declaration of Independence. This authorization does not allow any change or deviation from the Jewish and democratic definition. A democratic decision to change the Jewish character of the state is unconstitutional and invalid. The Jewish element therefore has an even higher normative status than the democratic one since democratic decision-making cannot change it. The most plausible conception of the People operating in this context is limited to the group designated in the Declaration of Independence, that is, the "the Jewish Community of Eretz-Israel and the Zionist movement".

The definition also plays a major role at different stages of the law-making process, which has been one of the markers of sovereignty since the times of Boudin and Hobbes. The definition structures the law-making process in two ways. The first is by ensuring that any legislation is firmly located within the Zionist consensus. The second is by relaxing the constitutional constraints on legislation that violates the rights of Palestinian citizens in circumstances where the legislation is important to the Zionist vision. These control mechanisms come in different forms, including the Knesset's Rules of Procedures, rules of statutory interpretation, and judicial review of legislation.

The combined examination of the role of the definition on the level of constitutionmaking and law-making suggests that the constitutional order operates in a manner that elevates the Jewish character of the state above democracy and precludes democratic attempts to challenge the definition. In this sense, the People that exercises sovereignty includes only those who agree with the Jewish definition of the state. 


\section{Conclusions}

\section{Moving Beyond Exclusionary Constitutionalism}

This dissertation has examined the meaning and implications of Israel's constitutional definition as a Jewish and democratic state. We explored how the definition is used - by a range of actors including the courts, state institutions, politician, and scholars - to justify, and at times consolidate and extend, institutionally imbedded discriminatory outcomes. We examined how the definition is entrenched, maintained and constantly regenerated within the constitutional order, and how it affects the internal ordering of the state and the processes of shaping the political community, political representation, and constitution-making. Using constitutional theory, the dissertation investigated the way that the Jewish and democratic definition of the state shapes the nature of the regime in Israel.

The inquiry here was based on the idea of the People, which, as discussed in chapter I, is central to modern constitutionalism. Given that Israel is defined as the state of the Jewish people, can we say that non-Jewish citizens are part of the People? To uncritically posit that the citizenry as a whole (including the $20 \%$ who are members of the Palestinian minority) is the People would be to avoid the hard questions about the Israeli constitutional order and the nature and quality of democracy in Israel. This dissertation has taken a different tack. We have investigated the question of "who is the People?" based on a broader picture of the constitutional order, a detailed examination of its features and of the principles and actors that influence its operation and outcomes.

The constitutional order, which is created by the People, controls the creation, transformation and exercise of political power. It harnesses the People's political power 
through representation, transforms it into the political authority of the state, which is governed by the constitution and exercised through law. Law controls some aspects of entry and exit from the People, and sets the rules for how executive power is used. Our examination of the founding and operation of the constitutional order in Israel demonstrated that the Jewish definition of the state functions at different stages to exclude the Palestinian citizens from the processes of generating and exercising political power. In essence, the definition acts as a filter at different vital stages to ensure that whatever rights the Palestinian citizens have to influence the system, are, to a large extent, neutralized. The outcome is that the power to establish, shape and influence the constitutional order is concentrated in the hands of Jewish citizens, despite the formal citizenship that the Palestinian citizens hold, and the civil and political rights that the state formally grants, such as the right to vote. In essence, the Palestinian citizens do not partake in the sovereignty or constituent power that the People exercises. In this sense they are excluded from the People.

The Declaration of the Establishment of the State of Israel embodies the foundational stage of the constitutional order. Our close reading of the text, and an examination of how the Supreme Court has used the Declaration, showed that the Declaration established the Jewish people as the People of the state. In fact, in the narrative it presents, the only group fit to be a People is the Jewish people, for the Arabs are presented as intruders on terra nullius. The Declaration's invitation to the Arab inhabitants of the state to join as equal citizens was conditional on accepting the Declaration's narrative. The People had already been formed, shaped and declared, and the conditional invitation to the Palestinians did not tolerate any other narrative or the creation of a new "we" or more inclusive understanding of the People. This often-celebrated paragraph embodies the "othering" of the Palestinian population and 
sets the tone for the dynamics of exclusionary constitutionalism. The People here, as a matter of law and in practice, is the Jewish citizens of the state. In the last two decades, the Declaration has become more prominent in legal and political discussions. For example, it is quoted or referenced in calls for future constitutional changes. In mainstream Israeli political discourse, its founding ideologies and assumptions are as important and acceptable today as they were in May 1948.

The dynamics of exclusion are also visible in immigration and citizenship laws and policies. As explained in chapter IV, these laws and policies are essential in shaping the membership in the state and by extension the People. Once the state was formed, it was under pressure to grant equal universal citizenship in order to legitimate itself. This is especially important in the case of a state whose legitimacy is continuously questioned, and one that usually situates itself as part of the "enlightened" western world. On the other hand, the state, being the product and the new medium of the Zionist movement, cannot disconnect itself from its history, roots and founding ideologies that see a Jewish majority and Jewish sovereignty as an ultimate goal. An inevitable corollary of this goal is restricting the growth of the Palestinian population to ensure it does not become so large as to threaten the political power of the Jewish majority. Immigration laws and policies oscillate between these two poles, offering a measure of inclusion through formal citizenship, but at the same time taking measures to reduce the availability of citizenship to Palestinians and actively promoting its acquisition by Jews. The outcome is a system that is designed to benefit the Jewish majority at the expense of the minority, and maintain the numerical preponderance of the majority in order that they may continue to shape the future People. Besides this functional role, the oscillation also means that what appears to be a universal form of citizenship has, in practice, 
several hierarchical categories in it based on religion or nationality. These categories present the Palestinian minority as outsiders, as an immigrant ethnic minority whose rights are subject to the interests of the Jewish majority. Therefore, these laws and policies, in addition to their functional role in shaping the future of the community and the People, also play a role in indicating who the insider dominant group is, the one that is the People.

Political representation has similar dynamics of exclusion. Basic Law: The Knesset establishes a universal adult franchise, and thus empowers all citizens as political actors. However, section $7 \mathrm{~A}$ of the same basic law and similar provisions in other statutes draw the red lines of political action around the definition of the state by banning candidates or parties whose political programme challenges the Jewish definition of the state. While the evidentiary, procedural and interpretative standards used by the Court create grey areas in which some parties or politicians can find refuge, the very existence of the provision is telling. The Jewish and democratic definition shapes the boundaries of permissible political discourse and activism. By doing so, it restricts the Palestinian citizens as political actors and acts as a gatekeeper for who and which ideas are allowed to enter the Knesset. It essentially ensures that rules that establish Zionist hegemony cannot be changed democratically. It also distances the Palestinian citizens from any centre of power within the state.

The dynamics of exclusionary constitutionalism are also palpable in the stage of constitution-making and law-making, and the related functions of interpretation and judicial review. The Supreme Court has ruled that any attempt to amend the Jewish and democratic definition of the state would be an unconstitutional constitutional amendment. The Jewish definition of the state cannot be changed democratically. It is beyond the reach of democracy. Similarly, the Rules of Procedures of the Knesset authorize the Knesset's Presidium to block any 
bill that the Presidium sees as negating the Jewish character of the state. Such a bill cannot even be debated. Moreover, once passed, legislation must be interpreted in light of the definition. Upholding the Jewish and democratic values of the state are presumptions in the process of statutory interpretation. Through the "limitation clauses" of Basic Law: Human Dignity and Freedom and Basic Law: Freedom of Occupation, the Jewish and democratic definition plays another role in the dynamics of exclusion. It essentially relaxes some of the requirements that legislation must meet in order to be constitutionally valid.

Taken together, these features constitute the dynamics of exclusionary constitutionalism that are fuelled by the Jewish definition of the state. The legislature, courts, politicians, academics, and other actors use the definition to justify, maintain and extend exclusionary constitutionalism. As our discussion has revealed, these dynamics are not always obvious and sometimes their exclusionary effects can be discerned only when placed in the larger picture of the constitutional order as a whole. In some cases, the dynamics of exclusion of non-Jews (especially Palestinians) from the People are the outcome of the operation of two contradictory trends, one providing a measure of inclusion through democratic principles, and another pushing in the direction of exclusion through Zionist principles. When the two come into conflict, the Jewish nature of the state prevails over its democratic character. In other words, the perceived requirements of Zionism ultimately define the contours of an exclusionary Israeli democracy.

The dissertation also has highlighted the impact of the colonial reality on the operation of the constitutional order. Some insights from the scholarship on settler colonialism help in explaining the dynamics of exclusionary constitutionalism. The impact of settler colonialism is visible at every stage we have examined. It finds expression in the terra nullius picture of 
Palestine painted by the Declaration of Establishment of the State of Israel. The logic of elimination, and the conflict over jurisdiction, which are central features of settler colonialism, is helpful in understanding Israeli immigration and citizenship laws and policies. The dynamics of difference identified by Anthony Anghie and conflict over jurisdiction also provided useful ways of understanding the dynamics of exclusion in political representation, as well as in constitution-making and law-making processes. The dynamics of difference show how any political idea that challenges the Jewish definition of the state is automatically "othered" and linked to violence, necessitating legal provisions to protect the state from such ideas and political actors. The conflict over jurisdiction (or sovereignty) helps explain exclusionary dynamics by emphasizing the role of political participation and law-making in the generation and exercise of the state's political authority.

What do these findings tell us about the nature of democracy in Israel? If we accept that in a democracy the People is sovereign, and it exercises this sovereignty through creating the constitutional order and through elections, the finding that the Palestinian minority is not part of the People has significant implications. It essentially breaks the reflexive identity between the governors and the governed. In this sense, Israel cannot be seen as a democracy for the Palestinian citizens, for they are only part of the governed and not part of the governors. But is democracy divisible? Can a state or a regime be democratic for some citizens and non-democratic for others? Can democracy within the tribe - as Azmi Bishara puts it ${ }^{1}$ be seen as democracy in the state? In this context, universality is one of the central features of democracy and its moral impetus. The impulse of universal, equal and equitable treatment is

${ }^{1}$ Azmi Bishara, From the Jewish State to Sharon: $A$ study in the Contradictions of the Israeli Democracy (in Arabic), (Ramallah: MUWATIN- The Palestinian Institute for the Study of Democracy, 2005) at 25. 
what maintains the internal morality of the idea of democracy. As such the nature of the regime in Israel cannot be seen as truly democratic.

Our examination focused on the role of the Jewish and democratic definition in discrete areas of the constitutional order and situated these areas in the larger picture in order to produce a comprehensive analysis of how the definition is used by different actors to produce the dynamics of exclusionary constitutionalism. While this analysis aimed to provide a fresh perspective on the meaning and impact of the definition of the Israeli state, it also aims to be useful in a prospective way. By identifying how the definition is used in each discrete area to produce the dynamics of exclusionary constitutionalism, one can discern what has to be changed. A roadmap for democratization starts to come into view. The issues discussed in this dissertation, and the ways in which apparently neutral rules or principles produce discriminatory results, are a good starting point for tackling the dynamics of exclusion.

This is of course no simple task, and requires formidable political will. An important first step is coming to terms with historical injustices and confronting historical narratives and conceptions. This step requires that we overcome what Nadim Rouhana calls "the politics of historical denial" - the Israeli official narrative of the Palestinian citizens as "Israeli Arabs", who lack historical roots or narratives, and live in the "Jewish homeland" in a manner similar to an immigrant community rather than as an indigenous group in a colonial reality. ${ }^{2}$ In essence, the democratization process should be seen as a decolonization process in order to weaken the ideologies, ideas and mindsets that resulted in the existing system.

2 Nadim N. Rouhana, "Reconciling History and Equal Citizenship in Israel: Democracy and the Politics of Historical Denial" in Will Kymlicka \& Bashir Bashir, eds, The Politics of Reconciliation in Multicultural Societies (Oxford: Oxford University Press, 2008) 85 at 86. 
While this is the hope for the future, it seems that things are currently heading in the opposite direction, one of expanding dynamics of exclusionary constitutionalism. In June 2013, the Law for the Regulation of Bedouin Settlement in the Negev - 2013, also known as the Prawar Plan, passed first reading in the Knesset. ${ }^{3}$ The plan includes the confiscation of about 800,000 dunum $^{4}$ of Bedouin land in the Naqab (Negev) and the displacement of 40,000 to 70,000 people. ${ }^{5}$ Another bill that passed first reading in July 2013 was the Knesset Elections Law (Amendment no. 61) (Raising the Threshold Rate and Empowering Governmentablity) -2013. If passed, this law will raise the electoral threshold percentage for representation of parties in the Knesset from the current $2 \%$ to $4 \%$ - a percentage that no-Arab party has ever achieved. ${ }^{6}$ While this does not totally prevent political representation (since parties can cooperate in the formation of one list that will pass this threshold), it nevertheless will have a dramatic effect on political pluralism in the Palestinian community. Another troubling bill that will be debated soon is Basic Law: Israel- The Nation State of the Jewish People. ${ }^{7}$ The bill seeks to entrench in a basic law some of the components of the definition of the state that we have discussed in this dissertation, such as an exclusive Jewish right to self-determination, immigration rights, and other aspects such as the status of Hebrew and symbols of the state such as the flag, emblem and anthem.

\footnotetext{
${ }^{3}$ Yanir Yagna \& Jonathan Lis, "Bedouin Relocation Plan Wins Slim Knesset Majority after Stormy 1st Reading", Haaretz (24 June 2013) online: <http://www.haaretz.com/news/national/premium-1.531794>.

${ }^{4}$ One dunum is 1,000 square meters.

${ }^{5}$ For details on the Prawar Plan, see Adalah, "The Arab Bedouin and the Prawar Plan: Ongoing Displacement in the Naqab", (2012) online: <http://ar.scribd.com/doc/122424008/The-Arab-Bedouin-and-the-Prawer-PlanOngoing-Displacement-in-the-Naqab $>$.

"Jonathan Lis, "Bill to Raise Knesset's Electoral Threshold Passes First Reading" Haaretz (31 July 2013), online : <http://www.haaretz.com/news/national/1.539043>.

7 Jonathan Lis, "Lawmakers Unveil Bill Seeking to Bolster Israel's Jewish Identity" Haaretz (26 June 2013), online: <http://www.haaretz.com/news/national/premium-1.532035>.
} 
While these developments indicate that exclusionary constitutionalism in Israel may yet expand and deepen, there are other factors that give some hope of a change in direction towards a more inclusive democracy. The current situation is not feasible in the long term, especially with the gradual increase in the proportion of Palestinian citizens in the population as a whole. If current demographic trends continue, they will intensify the contradiction between the Jewish and democratic elements of the definition of the state, making it more and more difficult to live with the contradictions over time, and perhaps ultimately pushing it to a point where it is not longer sustainable. The breaking point may usher in a new era of democratization, but it could also produce further intensification of the dynamics of exclusion.

In contemplating the future of the Israeli regime, we should bear in mind that electoral politics are not the only form of political activity. While the dynamics of exclusionary constitutionalism leave the Palestinian citizens outside the People and thus render electoral political of little use to the community, other forms of political organizing will be tried and may prove to be more effective. Activists have always mobilized to protest against state policies with varying degrees of success. Mobilization, however, has usually been local and not on a massive scale. But it seems that with the intensification of the dynamics of exclusion and the failure of electoral politics, the perception that electoral politics do not and should not subsume all forms of politics is gaining ground. More voices are calling for rebuilding existing representative institutions - such as the Higher Follow-Up Committee ${ }^{8}$ in a manner that

\footnotetext{
${ }^{8}$ The Higher Follow-Up Committee is an unelected committee that includes Arab members of the Knesset and representatives of political parties and some mayors and heads of local councils. While it is considered the most representative body of the Palestinians in Israel, it has no official status and, to a large extent, plays a marginal role in the political realm.
} 
bolsters their representative character through direct elections for example. ${ }^{9}$ An elected representative body will be more capable of garnering popular legitimacy to represent the Palestinian collective in Israel. Some conceive of such a body as an Arab parliament within the state. The creation of such a body may lead to the emergence of a competing claim for constituent power and sovereignty by the particular national group that has been excluded from the existing constitutional order. This, as Stephen Tierney shows, is one of the ways "to activate sub-state constituent power for the purpose of kick-starting meaningful constitutional dialogue." 10

Another form of activism is through existing legal channels within the state apparatus. As we have seen, Palestinians have sought recourse in Israeli courts since the creation of the state. Since the 1990 s however, there has been an increase in legal activism through litigation fueled by the rise of human rights discourse and the proliferation of NGOs. While a full assessment of this form of activism is a serious undertaking that requires in-depth empirical study, we can see from the cases examined in this dissertation that trends vary and range from limited success in some cases, to defeats that justify more discriminatory policies in others. In the context of the broader constitutional regime, we should bear in mind that the judiciary is one of the main bodies that expounded and promoted the Jewish and democratic definition, and more than any other body gave the definition its current meaning with all its implications. This mixed record has produced a range of opinions on the issue although most

\footnotetext{
${ }^{9}$ Mohammad Amara, "The Higher Follow-Up Committee for the Arab Citizens in Israel" in Nadim N. Rouhana \& Areej Sabbagh-Khouri, eds, The Palestinians in Israel: Readings in History, Politics and Society (Haifa: Mada AlCarmel, 2011) 90 online: <http://mada-research.org/en/files/2011/09/ebook-english-book.pdf>; Mohanad Mustafa, "The High Follow-up Committee and the Palestinian Situation in al-Dakhel" (September 2012) 15 Jadal online: < http://mada-research.org/en/files/2012/10/mohanad-mustafa-jadal-15.pdf $>$.

10 Stephen Tierney, "We the Peoples': Constituent Power and Constitutionalism in Plurinational States" in Martin Loughlin \& Neil Walker, eds, The Paradox of Constitutionalism: Constituent Power and Constitutional Form (Oxford: Oxford University Press, 2007) 229 at 240-241.
} 
commentators seem to be skeptical of advancing the position of the Palestinian minority through litigation in Israeli courts. ${ }^{11}$

The issues of the definition of the state as Jewish and democratic and its implications are situated within a broader regional and international context. Political actions should take this context into consideration. In the past decade, successive Israeli governments have been demanding that the world recognize Israel as a Jewish state. Recognition of Israel as a Jewish state has also been put forward as a demand that must be met by the Palestine Liberation Organization (PLO) in the negotiations towards a permanent resolution of the Israeli Arab conflict. ${ }^{12}$ Requiring recognition of Israel as a Jewish state as a negotiating position is usually understood as an attempt to undermine demands of the Palestinian refugees to return to areas that are now part of Israel since their return would shift the current demographic composition of the population in Israel. But it could also be understood as an attempt to gain recognition from the PLO in order to counter any challenges to the definition by Palestinians in Israel. ${ }^{13}$ In this regard, the issue of the definition and mobilization by the Palestinian citizens is very

${ }^{11}$ See e.g. Alaa Mahajna, "Litigation Within the Israeli Court System: A Double-Edged Sword" (May 2012) 13 Jadal online: <http://mada-tesearch.org/en/files/2012/05/Jadal13/Eng/Alaa-Mahajna.pdf>; Hassan Jabareen, "On Legal Advocacy and Legitimation of Control" (May 2012) 13 Jadal online: < http://madaresearch.org/en/files/2012/05/Jadal13/Eng/Jabarin-article.pdf>; Mazen Masri, "Back to Politics?" (May 2012) 13 Jadal online: <http://mada-research.org/en/files/2012/05/Jadal13/Eng/Mazen-article2.pdf>; Gad Bazilai, "The Ambivalence of Litigation: A Criticism of Power" (May 2012) 13 Jadal online: <http://madaresearch.org/en/files/2012/05/Jadal13/Eng/Gadi-barzilai.pdf>; Amal Jamal, "Litigation, Legitimation and Rethinking Counter-Hegemonic Struggle for Equality" (May 2012) 13 Jadal online: <http://madaresearch.org/en/files/2012/05/Jadal13/Eng/Amal-Article.pdf>.

${ }^{12}$ See e.g. comment number 6 of Israel's 14 comments on the Roadmap (the plan presented by the US in 2003 to restart the peace negotiations between Israel and he PLO): "In connection to both the introductory statements and the final settlement, declared references must be made to Israel's right to exist as a Jewish state and to the waiver of any right of return for Palestinian refugees to the State of Israel." "Israel's Response to the Road Map", (25 May 2003) online: The Knesset <http://www.knesset.gov.il/process/docs/roadmap_response_eng.htm>.

${ }^{13} \mathrm{~A}$ statement along those lines was made by Tsipi Livni, then Minister of Foreign Affairs in 2008, see "Livni: National aspirations of Israel's Arabs can be met by Palestinian homeland", Haaretz (11 December 2008) online: <http://www.haaretz.com/news/livni-national-aspirations-of-israel-s-arabs-can-be-met-by-palestinianhomeland-1.259321>. (Livni stated that "[o]nce a Palestinian state is established, I can come to the Palestinian citizens, whom we call Israeli Arabs, and say to them 'you are citizens with equal rights, but the national solution for you is elsewhere."). 
much tied to the broader Israeli-Palestinian conflict and the different developments in that arena. The Palestinians in Israel are essentially part of the larger Palestinian people, and, to a large extent, many of the policies described in this dissertation affect or even apply to other Palestinians especially those in the Occupied Palestinian Territory (OPT). Similarly, political trends and events in the OPT have their echoes among the Palestinians in Israel, the prime example being the wave of protest that took place in October 2000 as a reaction to the brutal suppression of the Second Intifada. ${ }^{14}$ In this context, the official negotiations between Israel and the PLO may further marginalize the issue of the impact of the definition on the Palestinian citizens, especially since, in effect, the Palestinian minority in Israel is not represented by either side. On the other hand, civil society activism seems to be promoting a stronger sense of unity through its different campaigns. ${ }^{15}$

The definition of the state was discussed (albeit very briefly) by the UN Committee on the Elimination of Racial Discrimination which raised concerns about the lack of a specific constitutional provision on equality. ${ }^{16}$ More recently, the issue of the status and treatment of the Palestinians in Israel became a source of concern for the European Union. ${ }^{17}$ This international interest, which is partly the result of lobbying by Palestinian civil society organizations based in Israel, indicates a growing interest, and possibly new strategies for activism.

${ }^{14}$ During this wave of protest 13 Palestinian citizens were killed by police.

15 This can be clearly seen in the global Boycott Divestment and Sanctions campaign which has "[r]ecognizing the fundamental rights of the Arab-Palestinian citizens of Israel to full equality" as one of its demands. See "Palestinian Civil Society Call for BDS", (9 July 2005) online: <http://www.bdsmovement.net/call>.

${ }^{16}$ Committee on the Elimination of Racial Discrimination, Concluding Observations of the Committee on the Elimination of Racial Discrimination: Israel, CERD, 70 th Sess, CERD/C/ISR/CO/13, (2007) online: <http://unispal.un.org/UNISPAL.NSF/0/041AB84D2F05080C85257302004A9963>.

17Donald MacIntyre, "Secret Paper Reveals EU Broadside over Plight of Israel's Arabs", The Independent (27 December 2011) online: <http://www.independent.co.uk/news/world/europe/secret-paper-reveals-eubroadside-over-plight-of-israels-arabs-6281816.hunl>. 
While the strategies and forums described above point to some of the possible ways forward, none of them is likely to bear fruit if deployed alone. Only a combination of strategies, rooted in a principled commitment to democracy, pluralism, equality and dignity, will be able to garner the moral force needed to unsettle the existing order and achieve change. 


\section{BIBLIOGRAPHY}

\section{CANADA}

\section{LEGISLATION (BY JURISDICTION)}

Canadian Charter of Rights and Freedoms, Part I of the Constitution Act, 1982, being Schedule B to the Canada Act 1982 (UK), 1982, c11.

\section{FRANCE}

Constitution of the French Republic, Constitution of October 4, 1958.

\section{GERMANY}

Basic Law of the Federal Republic of Germany.

\section{INDIA}

Constitution of India

\section{ISRAEL}

\section{BASIC LAWS}

Basic Law: Freedom of Occupation.

Basic Law: The Government.

Basic Law: Human Dignity and Freedom.

Basic Law: The Knesset.

Primary Legislation

Absentee Property Law-1950.

Broadcasting Authority Law-1965.

Citizenship Law-1959.

Citizenship and Entry to Israel Law (Temporary Order) (Amendment)- 2005.

Culture and Art Law- 2002.

Elections for the Constituent Assembly Ordinance-1948.

Emergency Regulations (Registration of Inbabitants), 1948.

Entry to Israel Law -1952.

Entry to Israel and Citizenship Law-2003. 
Equal Opportunities in Employment Law- 1988.

Foundations of Budget Law-1985.

Foundations of the Budget Law (Amendment No. 40) (Reduction of Budget or Support Because of Activity Against Principles of the State)- 2011.

Foundations of Law Act-1980.

General Security Service Law-2002.

Governmental Companies Law- 1975.

Governance and Law Order (1)-1967.

Immunity, Rights and Duties of Knesset Members Law- 1951.

Inbabitants Registration Ordinance-1949.

Israel Land Law-1960.

The Knesset Law- 1994.

Knesset Elections Law (Integrated Edition)- 1969.

Law and Administration Ordinance-1948.

Law and Administration Arrangements Law [Consolidated Version] -1970.

The Law of Return- 1950.

Local Autborities Law (Elections)-1965.

The Negev Development Authority Law (Amendment no.4)- 2010.

Ottoman Associations Law- 1909.

Parties Law-1992.

Probibition of Terror Financing Law-2005.

Public Education Law-1953.

Registration of Inbabitants Ordinance-1949.

Second Autbority for Television and Radio Law-1990. 
State Service Law (Appointments)-1959.

The Transition Law-1949.

Transition to the Constituent Assembly Ordinance, 1949.

World Zionist Organization and Jewish Agency Status Law -1952.

\section{SECONDARY LEGISLATION}

Rules of Procedures of the Knesset.

Second Authority for Television and Radio Regulations (Etbics in Advertisements in Radio Broadcasts)1999.

\section{BILLS}

Basic Law: Equality of the Arab Population Bill.

Basic Law: Israel- The Nation State of the Jewish People Bill.

Citizenship Law Bill (Amendment no. 4) - 1979.

Citizenship Law (Amendment no. 9) (Powers to Nullify Citizenship) Bill-2007.

Foundations of Budget Law (Nakba Denial Amendment) Bill -2011.

Knesset Elections Law (Amendment no. 61) Raising the Threshold Rate and Empowering Governmentablity) Bill-2013.

Regulation of Bedouin Settlement in the Negev Bill- 2013.

\section{ITALY}

Constitution of the Italian Republic.

Mandate Palestine

Immigration Ordinance- 1941.

Palestine Citizenship Order -1925.

Palestine Citizenship Order-1942.

\section{SOUTH AFRICA}

Constitution of the Republic of South Africa, 1996, No 1080 of 1996.

\section{UNITED STATES}

United States Constitution. 


\section{CANADA}

\section{JURISPRUDENCE (BY JURISDICTION)}

R. v. Oakes, [1986] 1 SCR 103.

\section{CoURT OF JUSTICE OF THE EUROPEAN UNION}

ECJ European Parliament v Council of the European Union, C-540/03, [2006] I-5769.

\section{European Court of Human Rights}

Abdulaziz, Cabales and Balkandali v UK (1985) 7 EHRR 471.

Priya v Denmark (dec), No 13594/03 (6 July 2006).

Z. and T. $v$ The United Kingdom (dec), No 27034/05 (28 February 2006).

\section{GERMANY}

Maastricht Treaty Case, 89 BVerfGE 155 (1993).

\section{ISRAEL}

CA (Tel-Aviv) 876/50 A.B. v. M.B. 3 PM 263.

HCJ 2271/98 Abed v. Minister of Interior (2001), IsrSC 55(5) 778.

HCJ 7803/06 Abu Arafeb v. Minister of Interior [pending].

HCJ 2605/05 Academic Centre for Law and Business v. Minister of Finance (2009).

HCJ 1113/99 Adalab- The Legal Center for the Rights of the Arab Minority in Israel v. Minister of Religious Affairs (2000), IsrSC 54(2) 164.

HCJ 7052/03 Adalab v Minister of Interior (2006), IsrSC 61(2) 202.

HCJ 7245/10, Adalab v. Minister of Welfare and Social Affairs (case pending).

HCJ 6698/96 'Adel Ka'dan v. Land Administration of Israel (2000), IsrSC 54 (1) 258.

HCJ 39/64 Al Ard Company Ltd. v Officer in Charge of the Northern District (1964), IsrSC 18(2) 340.

HCJ 3429/11 The Alumni of the Arab Orthodox High School in Haifa v. Minister of Finance (2012).

CLA 6709/98 Attorney General v Moledet, Gesher, Tsomet List for the Local Autbority Elections, Upper Nazareth (1999), IsrSC 53(1), 351. 
HCJ 282/88 Awad v. Prime Minister and Minister of Interior (1988), IsrSC 42(2) 424.

CLA 3145/99 Bank Leumi Ltd. v Hazan (2003), IsrSC 57(5) 385.

CA 6821/93 Bank Miszrabi HaMe'ouba v. Migdal Kfar Shitofui (1995), IsrSC 49 (2) 221.

HCJ 4908/10 Bar-On v. The Knesset (2010).

EA 2/88 Ben Shalom v. Central Elections Committee (1989), IsrSC 43(4) 221.

HCJ 98/69 Bergman v Minister of Finance (1969), IsrSC 23(1) 693.

HCJ 11255/03 Bishara v Attorney General (2006), IstSC 60(4) 287.

HCJ 265/87 Brasford v. Ministry of Interior (1989), IsrSC 43(4) 793.

EC 9255/12 Central Elections Committee for the Nineteenth Knesset v Zou'bi (2012).

EC 11280/02 Central Elections Committee for the Sixteenth Knesset v Tibi (2003), IsrSC 57(4) 1.

FH 16/61 Company Registrar v Kardoush (1962), IsrSC 16(2) 1209.

HCJ 164/97 Contram Ltd. V. Ministry of Finance- Customs and VAT Branch (1998), IsrSC 42(1) 289.

HCJ 246/81 Derekh Eretz Association v Broadcasting Authority (1981), IsrSC 25(4).

HCJ 5026/04 Design 22- Shark Deluxe Furniture Ltd v Head of the Shabath Work Permits Branch in the Ministry of Work and Welfare (2006), IsrSC 60(1) 38.

HCJ 4156/01 Dimitrov v. Ministry of Interior (2002) IsrSC 56(6) 289.

HCJ 563/77 Dorflinger v. Minister of Interior (1979), IsrSc 33(2) 97.

EA 2600/99 Erlich v. Chairman of CEC (1999), IsrSC 53(3) 38.

HCJ 466/07 Galon v. The Attorney General (2012).

HCJ 1661/05 Gaza Shore Regional Council v The Knesset (2005), IsrSC 59(2) 481.

CrimVR 537/95 Ghneimat v. State of Israel (1995), IsrSC 49 (3) 355.

CrimFH 2316/96 Ghneimat v. State of Israel (1995), IsrSC 49(4) 589.

FH 13/80 Hendles v. Bank Koopat HaAam Ltd. (1981), IsrSC 35(2) 785. 
HCJ 5016/96 Horev v. Minister of Transport (1997), IsrSC 51(4) 1.

HCJ 9037/02 Hujeirat Raf'a v. Ministry of Interior (2006).

HCJ 174/52 Hussein, acting for Mobammad Ali Abu Dabood v. The Commander of Acre Prison (1952), IsrSC 6897.

HCJ 1715/97 Investment Managers Bureau v Minister of Finance (1997), IsrSC 51(4) 367.

CLA 2316/96 Isakson v Parties Registrar (1996), IsrSC 50(2) 529.

HCJ 1635/90 Jarjevski v. Prime Minister (1991), IsrSC 45(2) 749.

HCJ 7164/02 Joumis v. Minister of Interior (2004), IsrSc 59(2) 232.

HCJ 253/64 Jiryis v Officer in Charge of the Northern District (1964), IsrSC 18(4) 673.

HCJ 742/84 Kabane v. Speaker of the Knesset (1985), IsrSC 29(4) 85.

HCJ 669/85 Kahane v. Speaker of the Knesset (1985), IsrSC 30(4)393.

HCJ 241/60 Kardoush v Company Registrar (1961), IsrSC 15(2) 1151.

HCJ 758/88 Kendel v. Minister of Interior (1992), IsrSC 46(4) 505.

HCJ 73/53 Kol Ha'Am v. Minister of Interior (1953), IsrSC 7(2) 871.

HCJ 142/89 La'or Movement v. Speaker of the Knesset (1990), IsrSC 44(3) 529.

HCJ 6893/05 Levi v Government of Israel (2005), IsrSC 59(2) 876.

HCJ 5131/03 Litzman v Speaker of the Knesset (2005), IsrSC 59(1) 577.

HCJ 4769/95 Menachem v Minister of Transport (2002), IsrSC 57(3) 235.

HCJ 620/85 Mi'ari v Speaker of the Knesset (1987), IsrSC 41(4) 169.

HCJ 761/86 Mi'ari v. Speaker of the Knesset (1987), IsrSC 42(4) 868.

FH 3/63 Minister of Interior v Musa (1963), IsrSC 162467.

HCJ 3872/93 Mitral Ltd. $v$ Prime Minister and Minister of Religions (1993), IsrSC 46(5) 485.

HCJ 6427/02 The Movement for the Quality of Governance in Israel v. The Knesset (2006).

HCJ 328/60 Musa v. Minister of Interior (1962), IsrSC 16. 
HCJ 112/52 Nakara v. Minister of Interior (1953), IsrSC 7, 955.

HCJ 4822/02 The National Committee of Arab Mayors v. Speaker of the Knesset (2003).

EA 561/09 The National Democratic Assembly v. Central Elections Committee for the $18^{\text {th }}$ Knesset (2009).

HCJ 344/81 Negbi v Central Elections Committee for the Tenth Knesset (1981), IsrSC 35(4) 837.

EA 2/84 Neiman v. Chairman of the Central Elections Committee for the Eleventh Knesset (1985), IsrSC 39(2) 225.

EA 1/88 Neiman v Chairman of the Central Elections Committee for the Twelfth Knesset (1988), IsrSC 42(4) 177.

HCJ 975/89 Nimrodi Land Development Ltd. v Speaker of the Knesset (1991), IsrSC 45(3) 154.

HCJ 209/73 Odeh (Lafi) v. Minister of Interior (1973), IsrSC 28(1) 13.

HP (Jerusalem) 6092/07 Ornan v. Ministry of Interior (2008) [pending appeal].

HCJ 1030/99 Oron v Speaker of the Knesset (2002), IsrSC 56(3) 640.

HCJ1031/93 Pesro (Goldstein) v. Minister of Interior (1995) IsrSC 49(4) 661.

HCJ 1843/93 Pinhasi v The Knesset (1996), IsrSC 49(1) 661.

CrimA 228/60 Qabwaji v. The Attorney General (1960), IsrSC 14(3) 1929.

HCJ 72/62 Raufeisen v. Minister of Interior (1962), IsrSC 132430.

HCJ 58/68 Schalit v. Minister of Interior (1970), IsrSC 23 (2) 477.

HCJ 153/87 Shakdi'el v. Minister of Religious Affairs (1988), IsrSC 42 (2) 221.

HCJ 3648/97 Stamka v. The Minister of Interior (1999), IsrSC 53(2) 728.

Crim File (Tel-Aviv) 12318-12-09 State of Israel v. Barakeb (2011).

CA 630/70 Tamarin v. The State of Israel (1972), IsrSC 26(1).

HCJ 5478/11 Tibi v. Speaker of the Knesset (2013).

HCJ 2597/99 Toshbeim v. Minister of Interior (2004).

HCJ 2597/99 Tosbbeim v. Minister of Interior (2005), IsrSC 59(3) 721. 
HCJ 200/83 Wattad v. Minister of Finance (1984), IsrSC 28(3) 113.

CLA 7504/95 Yaseen v Parties Registrar (1996), IsrSC 50(2) 45.

EA 1/65 Yerdor v. Central Election Committee for the Sixth Knesset (1965), IsrSC 19 (3) 365.

HCJ 780/83 Yeshivat Tomchei Tmeemeem Mercarit v. State of Israel (1984), IsrSC 38 (2) 273.

HCJ 10/48 Zeev v. Officer in Charge the Tel-Aviv Urban Area (1948), IsrSC 185.

HCJ 10609/07 Zo'abi v. Minister of Interior (2011).

HCJ 10226/08 Zvidovsky v. Minister of Interior (2010).

\section{UNITED KINGDOM}

Huang $v$ Secretary of State for the Home Department, [2007] AC 167 (HL).

\section{UNITED STATES}

Dred Scott v. Sanford, 60 U.S. 393 (1857).

\section{SECONDARY SOURCES: MONOGRAPHS}

Abu Hussein, Hussein \& Fiona McKay. Access Denied Palestinian Land Rights in Israel (London: Zed Books, 2003).

Abu Sitta, Salman. Atlas of Palestine (London : Palestine Land Society, 2004).

Ackerman, Bruce. We the People: Beginnings (Cambridge MA: Cambridge University Press, 1991).

Anderson, Benedict. Imagined Communities: Reflections on the Origins and Spread of Nationalism, revised ed (London: Verso, 2006).

Anghie, Anthony. Imperialism, Sovereignty and the Making of International Law (Cambridge: Cambridge University Press, 2004).

Arendt, Hannah. The Origins of Totalitarianism (Orlando, FL: Harcourt Brace and Company, 1951).

Avineri, Shlomo, Liav Orgad \& Amnon Rubenstein. Managing Global Migration: A Strategy for Immigration Poligy for Israel Jerusalem: The Metzilah Center, 2010) online: <http://www.metzilah.org/English/Immi_Book\%20final.pdf $>$.

Azoulay, Ariella \& Adi Ophir. This Regime Which is Not One: Occupation and Democracy Between the Sea and the River (1967-) (in Hebrew) (Tel-Aviv: Resling Publishing, 2008). 
Barak, Aharon. Interpretation in Law (in Hebrew) Jerusalem: Nevo Publishing, 1994). A Judge in a Democratic Society (In Hebrew) (Jerusalem: Nevo, 2004).

Barzilai, Gad. Communities and Law: Politics and Cultures of Legal Identities (Ann Arbor: University of Michigan Press, 2003).

Bellamy, Richard. Political Constitutionalism: A Republican Defence of the Constitutionality of Democracy (Cambridge: Cambridge University Press, 2007).

Ben-Gurion, David. Israel: A Personal History (New York: Funk \& Wagnalls Inc., 1971).

Bendor, Ariel L. \& Zeev Segal, The Hat Maker: Discussions with Justice Aharon Barak (in Hebrew) (Or Yehuda: Kinneret Zmora-Bitan Dvir Publishing House Ltd., 2009).

Benziman, Uzi \& Mansour Atalla. Subtenants (in Hebrew) (Jerusalem: Keter Publishing House, 1992).

Bishara, Azmi. From the Jewish State to Sharon: A study in the Contradictions of the Israeli Democracy (in Arabic) (Ramallah: MUWATIN- The Palestinian Institute for the Study of Democracy, 2005). 2009).

Bodin, Jean. On Sovereignty: Four Chapters From Six Books of the Commonwealth, translated by Julian H. Franklin (Cambridge: Cambridge University Press, 1992).

Carmi, Na'ama. The Law of Return: Immigration Rights and Their Limits (in Hebrew) (Tel-Aviv: Tel-Aviv University Press, 2003).

Carré de Malberg, R. Contribution à la Théorie générale de l'État (Paris: Librarie de la sociét du Recueil Sirey, 1920).

Cheshin, Amir. Municipal Policies in Jerusalem - An Account from Within (Jerusalem, PASSIA, 1998).

Chomsky, Noam. Profit Over People (New York: Seven Stories Press, 1999).

Corinaldi, Michael. The Enigma of Jewish Identity: The Law of Return in Theory and Practice (in Hebrew) (Srigim Leon, Israel: Nevo Publishing, 2001).

DellaPergola, Sergio. Jewish Demographic Policies: Population Trends and Options in Israel and in the Diaspora Jerusalem: The Jewish People Policy Institute, 2011) online: <http://ippi.org.il/uploads/Jewish_Demographic_Policies.pdf $>$. 
Dershowitz, Alan. The Case for Israel (Hoboken, NJ: John Wiley \& Sons, 2003).

Dumper, Michael. The Politics of Jerusalem Since 1967 (New York: Columbia University Press, 1997).

Cohen, Hillel. Army of Shadows: Palestinian Collaboration with Zionism, 1917-1948 (Berkley: University of California Press, 2008).

Dworkin, Ronald. Law's Empire (Cambridge, MA: Belknap Press of Harvard University Press, 1986).

Freedom's Law: The Moral Reading of the American Constitution (Oxford: Oxford University Press, 1996).

Dyzenhaus, David. Legality and Legitimacy: Carl Schmitt, Hans Kelsen and Hermann Heller in Weimar (Oxford: Clarendon Press, 1997).

Feilglin, Moshe. Dreams War: From the State of the Jews to the Jewish State (in Hebrew) (np: Jewish Leadership, 2005).

Frilling, Tuvia, ed, An Answer to a Post-Zionist Colleague (in Hebrew)(Tel-Aviv: Yedi'ot Aharaonot Publiser \& Sefrei Hemed, 2003).

Gans, Chaim. The Limits of Nationalism (Cambridge: Cambridge University Press, 2002).

From Richard Wagner to the Palestinian Right of Return: Pbilosophical Analysis of Israeli Public Affairs (in Hebrew) (Tel-Aviv: Am Oved Publisher, 2006).

. A Just Zionism (Oxford and New York: Oxford University Press, 2008).

Gavison, Ruth. Israel as a Jewish and Democratic State: Tensions and Possibilities (in Hebrew) (Jerusalem: VanLeer and Hakibutz Hameuhad, 1999).

Ghanem, As'ad. Ethnic Politics in Israel: The Margins and the Asbkenazi Center (London: Routledge, 2010).

Gouldman, M.D. Israel Nationality Law (Jerusalem: Institute for Legislative Research and Comparative Law, 1970).

Halpern, Ben. The Idea of the Jewish State, 2d ed (Cambridge, MA: Harvard University Press, 1969).

Herzl, Theodor. The Jewish State: An Attempt at a Modern Solution of the Jewish Question (London: Henry Pordes, 1993).

Hess, Moses. Rome and Jerusalem: A Study in Jewish Nationalism (New York: Bloch Publishing 
Company, 1945).

Hobbes, Thomas. De Cive, ed by Howard Warrender (Oxford: Clarendon Press, 1983).

Hobbes, Thomas. Leviathan, ed by Richard Tuck (Cambridge: Cambridge University Press, 1991).

Hofnung, Menachem. Israel- Security Needs vs. The Rule of Law (in Hebrew) Jerusalem: Nevo Publishing, 1991).

Irving, Helen. Gender and the Constitution: Equity and Agency in Comparative Constitutional Design (Cambridge: Cambridge University Press, 2008).

Jabbour, George. Settler Colonialism in Southern Africa and the Middle East (Khartoum: The University of Khartoum and the Palestine Liberation Organization Research Centre, 1970).

Jamal, Amal. Arab Minority Nationalism in Israel (London: Routledge, 2011).

Jiryis, Sabri. The Arabs in Israel (New York: Monthly Review Press, 1976)

Jones, Clive. Soviet Jewish Aliya 1989-1992: Impact and Implications for Israel and the Middle East (London: Frank Cass, 1996).

Kahane, Meir. They Must Go (New York: Grosset \& Dunlap, 1981). . Uncomfortable Questions for Comfortable Jews (Seacaucus, NJ: Lyle Stuart Inc., 1987).

Kahn, Susan Martha. Reproducing Jews: A Cultural Account of Assisted Conception in Israel (Durham, NC: Duke University Press, 2000).

Kanaaneh, Rhoda Ann. Birtbing the Nation: Strategies of Palestinian Women In Israel (Berkeley: University of California Press, 2002).

Kattan, Victor. From Coexistence to Conquest: International Law and the Origins of the Arab-Israeli Conflict, 1891-1949 (London: Pluto Press, 2009).

Kelsen, Hans. Pure Theory of Law, translated by Max Knigt (Berkeley: University of California Press, 1970).

Kimmerling, Baruch. Zionism and Territory: The Socio-Territorial Dimensions of Zionist Politics (Berkeley: Institute of International Studies, 1983).

Clash of Identities: Explorations in Israel and Palestinian Societies (New York: Columbia University Press, 2008).

Klein, Claude. Israel as a Nation State and the Problem of the Arab Minority: In Search of a Status (Tel- 
Aviv: International Center for Peace in the Middle East, 1987).

Kommers, Donald P. \& Russel A. Miller. The Constitutional Jurisprudence of the Federal Republic of Germany, 3d ed (Durham: Duke University Press, 2012).

Kotler, Yair. Heil Kabane (New York: Adama Books, 1986).

Will Kymlicka, Multicultural Citizenship: A Liberal Theory of Minority Rights (Oxford: Clarendon Press, 1995).

Politics in the Vermacular: Nationalism, Multiculturalism, and Citizenship (Oxford \& New York: Oxford University Press, 2001).

Lahav, Pnina. Judgement in Jerusalem: Chief Justice Simon Agranat and the Zionist Century (Berkeley: University of California Press, 1997).

Lloyd George, David. The Truth About the Peace Treaties (London: Victor Gollancz, 1938).

Locke, John. The Second Treatise: An Essay Concerning the True Original, Extent, and End of Civil Government, ed by Ian Shapiro (New Haven: Yale University Press, 2003).

Loughlin, Martin. The Idea of Public Law (Oxford: Oxford University Press, 2003).

Loughlin, Martin. Foundations of Public Law (Oxford: Oxford University Press, 2010).

Lustick, Ian. Arabs in the Jewish State: Israel's Control of a National Minority (Austin: University of Texas Press, 1980).

MacCormick, Neil. Questioning Sovereignty (Oxford: Oxford University Press, 1999).

Macklem, Patrick. Indigenous Difference and the Constitution of Canada (Toronto: University of Toronto Press, 2001).

Masalha, Nur. The Expulsion of the Palestinians: The Concept of 'Transfer' in Zionist Political Thinking (Washington D.C.: Institute of Palestine Studies, 1992).

A Land Without a People: Israel, Transfer and the Palestinians 1949-96 (London: Faber and Faber, 1997).

Politics of Denial: Israel and the Palestinian Refugee Problem (London: Pluto Press, 2003).

McIlwain, Charles Howard. Constitutionalism: Ancient and Modern (Ithaca, NY: Cornell University Press, 1947).

Medding, Peter. The Founding of the Israeli Democracy 1948-1967 (New York: Oxford University Press, 1990). 
Morgan, Edmund S. Inventing the People: The Rise of Popular Sovereignty in England and America (New York: W.W. Norton \& Company, 1988).

Morris, Benny. The Birth of the Palestinian Refugee Problem, $1947-1949$ (Cambridge: Cambridge University Press, 1987).

Israel's Border Wars, 1949-1956: Arab Infiltration, Israeli Retaliation, and the Countdown to the Suez War (Oxford: Oxford University Press, 1993).

. The Birth of the Palestinian Refugee Problem Revisited (Cambridge: Cambridge University Press, 2004).

Mouffe, Chantal. On the Political (New York: Routledge, 2005).

Nahas, Dunia Habib. The Israeli Communist Party (London: Portico Publications, 1976).

Negri, Antonio. Insurgencies: Constituent Power and the Modern State (Minneapolis: University of Minnesota Press, 1999).

Paine, Thomas. Common Sense and Other Writings, by J.M. Opal (London: W.W. Norton \& Company, 2012).

Pappe, Ilan. The Ethnic Cleansing of Palestine (Oxford: One World, 2007).

The Forgotten Palestinians: A History of the Palestinians in Israel (New Heaven, CT: Yale university Press, 2011).

Peretz, Don. Israel and the Palestine Arabs (Washington D.C.: The Middle East Institute, 1958).

Peretz, Don \& Gideon Doron. The Government and Politics of Israel, 3d ed (Boulder, Co: Westview Press, 1997).

Piterberg, Gabriel. The Returns of Zionism: Myths, Politics and Scholarship in Israel (London: Verso, 2008).

Pufendorf, Samuel. On the Duty of Man and Citizen According to Natural Law, ed by James Tully, translated by Michael Silverthrone (Cambridge: Cambridge University Press, 1991).

Qafisheh, Mutaz M. The International Law Foundations of Palestinian Nationality: An Examination of Nationality in Palestine Under Britain's Rule (Leiden: Martinus Neijhoff, 2008).

Rawls, John. A Theory of Justice (Cambridge: Belknap Press, 1971). Political Liberalism (New York: Columbia University Press, 1993).

Raz, Joseph. The Morality of Freedom (Oxford: Clarendon Press, 1986). 
Rodinson, Maxime. Israel: a Colonial Settler State? (New York: Monad Press, 1973).

Rouhana, Nadim. Palestinian Citizens in an Ethnic Jewish State: Identities in Conflict (New Haven: Yale University Press, 1997).

ed, Attitudes of Palestinians in Israel on Key Political and Social Issues: Survey Research Results (Haifa: Mada al Carmel, 2007).

Rouhana, Nadim N., Nabil Saleh \& Nimer Sultany, Voting Without Voice: The Palestinian Minority in the Israeli Parliamentary Elections (Haifa: Mada al-Carmel, 2003).

Rowbottom, Jacob. Democracy Distorted: Wealth, Influence and Democratic Politics (Cambridge: Cambridge University Press, 2010).

Rubinstein, Amnon \& Alexander Yakobson. Israel and the Family of Nations: A Jewish Nation State and Human Rights (in Hebrew) Jerusalem: Schoken Publishing House, 2003) Israel and Family of Nations (New York: Routledge, 2009).

Rubenstein, Amnon \& Barak Medina. Constitutional Law of the State of Israel (in Hebrew), 6th ed, (Jerusalem: Schocken Publishing House, 2005).

Said, Edward. The Question of Palestine (New York: Times Books, 1979).

Sand, Shlomo. The Invention of the Jewish People (London: Verso, 2009).

Sapir, Gideon. Constitutional Revolution in Israel: Past, Present and Future (in Hebrew) (Tel Aviv: Yedioth Aharonoth Books and others, 2010).

Sayeg, Fayez. Zionist Colonialism in Palestine (Beirut: Research Center - Palestine Liberation Organization, 1965).

Schmitt, Carl. The Concept of the Political, translated by George Schwab (New Brunswick, NJ: Rutgers University Press, 1976).

, The Crisis of Parliamentary Democray, translate by Ellen Kennedy (Cambridge, MA: The MIT Press, 1985).

. Constitutional Theory, tanslated by Jeffery Seitzer (Durham, NC: Duke University Press, 2008).

Shafir, Gershon \& Yoav Peled. Being Israeli: the Dynamics of Multiple Citizenship (Cambridge: Cambridge University Press, 2004).

Sieyès, Emmanuel Joseph. What is the Third Estate, translated by M. Blondel (New York and London: Fredrick a. Praeger Publisher, 1963). 
Tamir, Yael. Liberal Nationalism (Princeton: Princeton University Press, 1993).

Teitel, Ruti. Transitional Justice (Oxford: Oxford University Press, 2000).

Teveth, Shabtai. Ben Gurion and the Palestinian Arabs: From Peace to War (Oxford: Oxford University Press, 1985).

Tully, James. Strange Multiplicity: Constitutionalism in an Age of Diversity (Cambridge: Cambridge University Press, 1995).

Veracini, Lorenzon. Israel and Settler Society (London: Pluto Press, 2006).

Vital, David. The Origins of Zionism (Oxford: Oxford University Press, 1980).

Waldron, Jeremy. Law and Disagreement (Oxford: Oxford University Press, 1999).

Walzer, Michael. Spheres of Justice: A Defense of Pluralism and Equality (New York: Basic Books, 1983).

Warhaftig, Zerach. A Constitution For Israel: Religion and the State (in Hebrew) (Jerusalem: Mesilot Publications- The International Centre of the Mizrhai- The Mizrahi Worker, 1988).

Žižek, Slavoj. First as Tragedy, Then as Farce (London: Verso, 2009).

Yiftachel, Oren. Ethnocracy: Land and Identity Politics in Israel/Palestine (Philadelphia, PA: University of Pennsylvania Press, 2006).

Zureik, Elia T. The Palestinians in Israel: A Study in Internal Colonialism (London: Routldge \& Kegan Paul, 1979).

\section{SECONDARY SOURCES: ARTICLES}

Aaronsohn, Ran. "Settlement in Eretz Israel: A Colonial Enterprise? 'Critical' Scholarship and Historical Geograpy" (1996) 1:2 Israel Studies 214.

Abdo, Nahla \& Nira Yuval-Davis. "Palestine, Israel and the Zionist Settler Project" in Daiva Stasiulis \& Nira Yuvl-Davis, eds, Unsettling Settler Societies (London: Sage Publications, 1995).

Abizadeh, Arash. "Liberal Nationalist Versus Postnational Social Integration: On the Nation's Ethno-Cultural Particularity and 'Concreteness"' (2004) 10:3 Nations and Nationalism 231.

Ackerman, Bruce. “The Storrs Lecture: Discovering the Constitution” (1983-1984) 93 Yale Law Journal 1013. 
Alberts, Richard. "Nonconstitutional Amendments" (2009) 22 Canadian Journal of Law and Jurisprudence 5.

Amara, Ahmad \& Zinaida Miller. "Unsettling Settlements: Law, Land, and Planning in the Naqab" in Ahmad Amara, Ismael Abu-Saad \& Oren Yiftachel, eds, Indigenous (In)Justice: Human Rights Law and Bedouin Arabs in the Naqab/Negev (Cambridge, MA: Harvard University Press, 2012) 69.

Amara, Mohammad. "The Higher Follow-Up Committee for the Arab Citizens in Israel" in Nadim N. Rouhana \& Areej Sabbagh-Khouri, eds, The Palestinians in Israel: Readings in History, Politics and Society (Haifa: Mada Al-Carmel, 2011) 90 online: <http://madaresearch.org/en/files/2011/09/ebook-english-book.pdf >.

Arato, Andrew. "Forms of Constitution Making and Theories of Democracy" (1995-1996) 17 Cardozo Law Review 191.

Avineri, Shlomo. in Ron Margolin, ed, The State of Israel as a Jewish and Democratic State: A Discussion and Related Source (in Hebrew) Jerusalem: International Association for Jewish Studies, 1997) 36.

Barak, Aharon. "The Constitutional Revolution: Protected Basic Rights" (in Hebrew) (1992) 1 Mishpat o Mimshal 9.

. "Protected Human Rights: Scope and Limitations" (in Hebrew) (1993) 1 Mishpat o Mimshat 253.

"Protected Human Rights and Private Law" in Yitshak Zamir, ed, The Klinghofer Book on Public Law (in Hebrew) Jerusalem: Harry and Michael Sacher Institute for Legislative Research and Comparative Law, 1993).

. "The Role of the Supreme Court in a Democracy" (1998) 3:2 Israel Studies 2.

. "The State of Israel as a Jewish and Democratic State" (in Hebrew) (2000) 24 Iyunei Mishpat 1.

. "The Values of the State of Israel as a Jewish and Democratic State" in Chaim H. Cohen \& Yitzhak Zamir, eds, Aharon Barak: Selected Essays (in Hebrew) Jerusalem: Nevo, 2000) 445.

. "Unconstitutional Constitutional Amendments" (2011) 44 Israel Law Review, 321.

Barak-Erez, Daphne. "Israel: Citizenship and Immigration Law in the Vise of Security, Nationality, and Human Rights" (2008) 6 International Journal of Constitutional Law 184.

Barzilai, Gad. "Fantasises of Liberalism and Liberal Jurisprudence: State Law, Politics, and the 
Israeli Arab-Palestinians Community” (2000) 34 Israel Law Review 425.

Bendor, Ariel. "The Candidacy Right in the Knesset Elections" (in Hebrew) (1987-1988) 18 Mishpatim, 269.

"The Constitutional Status of the Rules of Procedures of the Knesset" (in Hebrew) (1994) 22 Mishpatim 571.

Ben-Shemesh, Yacov. "Immigration Rights and the Demographic Consideration", online (2008) 2:1 Law\& Ethics of Human Rights 15.

Bishara, Azmi. "The Sovereignty Process is Not Yet Complete" in David Joseph, ed, The State of Israel: Between Judaism and Democracy (Jerusalem: Israeli Democracy Institute, 2003).

Bosniak, Linda. "Persons and Citizens in Constitutional Thought" (2010) 8:1 International Journal of Constitutional Law 9.

Carmi, Na'ama. "Immigration Policy: Between Demographic Considerations and Preservation of Culture" (2008) 2:1 Law \& Ethics of Human Rights 22.

Chechin, Michel. "Responses" (in Hebrew) (2007) 6 Ma'zanei Mishpat 503.

Choudhry, Sujit. "Old Imperial Dilemmas and the New Nation-Building: Constitutive Constitutional Politics in Multinational Polities" (2005) 37 Connecticut Law Review 933.

Cohen, Asher \& Bernard Susser. "Jews and Others: Non-Jewish Jews in Israel" (2009) 15:1 Israel Affairs 52.

Colon-Rios, Joel. "The Legitimacy of the Juridical: Constituent Power, Democracy and the Limits of Constitutional Reform" (2010) 48 Osgoode Hall Law Journal 199.

Cover, Robert. "Violence and the Word" (1985-1986) 95 Yale Law Journal 1601.

Derrida, Jacques. “Declarations of Independence” (1986) 7:1 New Political Science 7.

Dyzenhaus, David. "The Politics of the Question of Constituent Power" in Martin Loughlin \& Neil Walker, eds, The Paradox of Constitutionalism: Constituent Power and Constitutional Form (Oxford: Oxford University Press, 2007) 129.

Dowty, Alan. 'Is Israel Democratic? Substance and Semantic in the 'Ethnic Democracy' Debate" (1999) 4:2 Israel Studies 1.

Dworkin, Ronald. “Law as Interpretation” (1982) 9(1) Critical Inquiry 179.

Elon, Menachem. "Constitution by Legislation: The Values of a Jewish and Democratic State in the Light of the Basic Law: Human Dignity and Personal Freedom" (in Hebrew) 
(1992-1993) 17 Iyunei Mishpat 659.

Falah, Ghazi. "Israeli 'Judaization' Policy in Galilee” (1991) 20:4 Journal of Palestine Studies 69.

Feldman, Avigdor. "The Democratic State versus the Jewish State: Space with no Places, Time with no Duration" (in Hebrew) (2005) 19 Iyunei Mishpat 717.

Forsyth, Murry. "Thomas Hobbes and the Constituent Power of the People" (1981) 29 Political Studies 191.

Freeman, Samuel. "Constitutional Democracy and the Legitimacy of Judicial Review" (1990) 9:4 Law and Philosophy 327.

Gans, Chaim. "Nationalist Priorities and Restrictions in Immigration: The Case of Israel" (2008) 2(1) Law \& Ethics of Human Rights 12.

Gavison, Ruth. "The Controversy over Israel's Bill of Rights" (1985) 15 Israel Yearbook on Human Rights 113.

. "A Jewish and Democratic State: Political Identity, Ideology and Law" (in Hebrw) (1995) 19 Iyunei Mishpat 631.

. "The Constitutional Revolution - A Description of a Reality or a Self-Fulfilling Prophecy?” (in Hebrew) 28 (1997) Mishpatim 21.

."The Jewish State: The Principle Justification and the Desirable Character" (in Hebrew), (2002) 13 Tkhelet 50.

. "The Jews' Right to Statehood: A Defense" (2003) Azure 70.

. "Thoughts about the Significance and Implications of "Jewish" in the Expression "A Jewish and Democratic State"', in Aviezer Ravitzky \& Ydidia Z. Stern, eds, The Jewishness of Israel (In Hebrew) Jerusalem: Israel Democracy Institute, 2007) 107.

Ghanem, As'ad \& Muhannad Mustafa. "The Palestinians in Israel and the 2006 Knesset Elections: Political and Ideological Implications of Election Boycott" (2007) 6:1 Holy Land Studies Journal 51.

Ghanem, As'ad, Nadim Rouhana \& Oren Yiftachel. “Questioning 'Ethnic Democracy': A Response to Sammy Smooha” (1998) 3:2 Israel Studies 253.

Grey, Thomas C. "Constitutionalism: An Analytical Framework" in J. Roland. Pennock \& John W. Chapman, eds, Constitutionalism: Nomos XX (New York: New York University Press, 1979) 189.

Gross, Aeyal. "Democracy, Ethnicity and Constitutionalism in Israel: Between The Jewish 
State' and 'the Democratic State"' (in Hebrew) (2000) Sotsyologia Yesraeilit 2:2 647.

. "The Constitution, Reconciliation, and Transitional Justice: Lessons from South Africa and Israel" (2004) 40 Stanford Journal of International Law 47.

. "In Love with the Enemy: Justice, Truth, Integrity and Common Sense Between Israel and Utopia in the Citizenship Law Case" (in Hebrew) (2007) 23 Hamishpat 79.

Guberman, Shlomo. "Israel's Supra-Constitution” (October, 1967) 2:4 Israel Law Review 455.

Hirschl, Ran. "The 'Constitutional Revolution' and the Emergence of a New Economic Order in Israel” (1997) 2 Israel Studies 136.

_ "The Socio-Political Origins of Israel's Juristocracy" (2009) 16:3 Constellations 476.

Harris, Ron. "Jewish Democracy and Arab Politics: Al-Ard Movement at the Supreme Court" (in Hebrew) (2001) 10 Plileem 107.

Jabareen, Hassan. "Towards Critical Approaches to the Palestinian Minority: Citizenship, Nationhood and Feminism in Israeli Law" (in Hebrew) (2000) 9 Plileem 82.

. "The Future of Arab Citizenship in Israel: Jewish-Zionist Time in a Place with No Palestinian Memory" in Challenging Ethnic Citizenship, Daniel Levy \& Yifaat Weiss, eds, (New York: Berghahen Books, 2002) 196.

. "Ignoring the "Other", Book review of $A$ Judge in a Democratic Society by Aharon Barak, (2005) 14 Adalah's online: http://www.adalah.org/newsletter/eng/jun05/rev.pdf.

. "The Constitutional Conception of the 'Jewish and Democratic' State" in Honaida Ghanim \& Antwane Shalhat, eds, The Meaning of a Jewish State (in Arabic) (Ramallah: MADAR The Palestinian Forum for Israeli Studies, 2011) 33.

Jabareen, Yousef T. "Constitution Building and Equality in Deeply-Divided Societies: the Case of the Palestinian-Arab Minority in Israel" (2008) 26:2 Wisconsin International Law Journal 345.

Jamal, Amal. "Beyond 'Ethnic Democracy': State Structure, Multicultural Conflict and Differentiated Citizenship in Israel” (2002) 24:3 New Political Science 411.

. "Contradictions of State-Minority Relations in Israel: The Search for Clarifications" (2009) 16:3 Constellations 493.

Kalyvas, Andreas. "Popular Sovereignty, Democracy and the Constituent Power" (2005) 12 Constellations 223.

Kamir, Orit. "The Declaration [of Independence] Has Two Faces: The Zionist Declaration 
and the Democratic Declaration" (in Hebrew) (1999) 23 Iyunei Mishpat, 473.

Kant, Immanuel. "On the common saying: 'This may be true in theory, but it does not apply in practice"" in Hans Reiss, ed, Kant: Political Writings, 2d ed (Cambridge: Cambridge University Press, 1991).

Karayanni, Michael. "Multiculture Me No More! On Multicultural Qualifications and the Palestinian-Arab Minority of Israel” (2007) 215 Diogenes 39.

Karp, Yehudit. "Basic Law: Human Dignity and Freedom- Biography of Power Struggles" (in Hebrew) (1993) 1 Mishpat O Mimshal 323.

Kelsen, Hans. "On the Essence and Value of Democracy" in Arthur J. Jacobson \& Bernhard Schlink, eds, Weimar: A Jurisprudence of Crisis (Berkeley: University of California Press, 2000) 84.

Kimmerling, Baruch. "Religion, Nationalism and Democracy in Israel" (1999) 6:3 Constellations 341.

Klein, Claude. "Constituent Power in Israel” (1969-1970) (in Hebew) 2 Mishpatim 51. 203.

"Is There a Need for an Amending Power Theory?" (1978) 12 Israel Law Review

. "Basic Law: Human Dignity and Freedom: An Initial Normative Assessment" (in Hebrew) (1993) 1 HaMishpat 123.

"After the Bank Mizrabi Decision: Constituent Power Through the Mirror of the Supreme Court" (in Hebrew) (1997) 28 Mishpatim 341.

Koskenniemi, Martti. "Conclusion: Vocabularies of Sovereignty- Powers of a Paradox" in Hent Kalmo \& Quentin Skinner, eds, Sovereignty in Fragments: The Past, Present, and Future of a Contested Concept (Cambridge: Cambridge University Press, 2010) 233.

Kretzmer, David. "The New Basic Laws on Human Rights: A Mini-Revolution in Israeli Constitutional Law?” (1992) 26 Israel Law Review 238.

Kremintzer, Mordechai. "The Image of the State of Israel as a Jewish and Democratic State" in Aviezer Ravitzky \& Ydidia Z. Stern, eds, The Jewishness of Israel (in Hebrew) Jerusalem: Israel Democracy Institute, 2007) 395.

Leibler, Anat E. "'You Must Know Your Stock': Census as Surveillance Practice in 1948 and 1967" in Elia Zureik, David Lyon \& Yasmeen Abu-Laban, eds, Surveillance and Control in Israel/Palestine (London: Routledge, 2011) 247.

Leibler, Anat \& Daniel Breslau. "The Uncounted: Citizenship and Exclusion in the Israeli 
Census of 1948” (2005) 28:5 Ethnic and Racial Studies 880.

Lerner, Hana. "Democracy, Constitutionalism, and Identity: The Anomaly of the Israeli Case" (2004) 11:2 Constellations 237.

Lindahl, Hans. "Constituent Power and Reflexive Identity: Towards an Ontology of Collective Selfhood" in Martin Loughlin \& Neil Walker, eds, The Paradox of Constitutionalism: Constituent Power and Constitutional Form (Oxford: Oxford University Press, 2007) 22.

Loughlin, Martin. "Ten Tenets of Sovereignty" in Neil Walker, ed, Sovereignty in Transition (Oxford: Hart Publishing, 2003) 56.

Loughlin, Martin "What is Constitutionalisation" in Martin Loughlin \& Petra Dobner, eds, The Twilight of Constitutionalism (Oxford: Oxford University Press, 2010) 47.

Loughlin, Martin \& Neil Walker. "Introduction" in Martin Loughlin \& Neil Walker, eds, The Paradox of Constitutionalism: Constituent Power and Constitutional Form (Oxford: Oxford University Press, 2007) 1.

Masri, Mazen. "Love Suspended: Demography, Comparative Law, and Palestinian Couples in the Israeli Supreme Court" (2013) 22:3 Social and Legal Studies 309.

MacCormick, Neil. "Sovereignty and After" in Quentin Skinner \& Hent Kalmo, eds, Sovereignty in Fragments (Cambridge: Cambridge University Press, 2010) 152.

Macklem, Patrick. "Distributing Sovereignty: Indian Nations and Equality of Peoples" (1993) 45 Stanford Law Review 1311.

Medina, Barak. "Forty Years for the Yerdor Ruling: Rule of Law, Law of Nature, and the Limits of the Legitimate Discourse in the Jewish and Democratic State" (in Hebrew) (2006) 22 Mehkari Mishpat 327.

. "On the 'Infringement' on a Constitutional Right and 'Proper Purpose"' (in Hebrew) (2012) 15 Mishpat o Asakim 281.

Medina, Barak \& Ilan Saban. "Human Rights and Taking Risking: On Democracy, 'Ethnic Profiling' and the Tests of the Limitation Clause" (in Hebrew) (2009) 39 Mishpatim 47.

Michelman, Frank I. "Brennan and Democracy: The 1996-97 Brennan Center Symposium Lecture" (1998) 86:3 California Law Review 399.

Neuman, Gerald L. “Whose Constitution?” (1991) 100:4 Yale Law Journal 909.

Oz-Salzberger, Fania \& Eli Salzberger. "The Secret German Sources of the Israeli Supreme Court" (1998) 3:2 Israel Studies 159.

Pappe, Ilan. "An Uneasy Coexistence: Arabs and Jews in the Early years of Statehood" in S. 
Ilan Troen \& Noah Lucas, eds, Israel: The First Decade of Independence (Albany: State University of New York Press, 1995) 622.

Peled, Yoav. "Ethnic Democracy and the Legal Construction of Citizenship: Arab Citizens of the Jewish State" (1992) 86:2 American Political Science Association 432.

Preuss, Ulrich. "The Exercise of Constituent Power in Central and Eastern Europe" in Martin Loughlin \& Neil Walker, eds, The Paradox of Constitutionalism: Constituent Power and Constitutional Form (Oxford: Oxford University Press, 2007) 216.

Raz, Joseph. "Multiculturalism" (1998) 11:3 Ratio Juris 193.

. "Commentary: Against the Idea of a Jewish State" in Michael Walzer, Menachem Lorberbaum \& Noam J. Zohar, eds, The Jewish Political Tradition (New Haven \& London: Yale University Press, 2000).

Raz, Joseph \& Avishai Margalit. "National Self-Determination” (1990) 87:9 The Journal of Philosophy 459.

Reed Amar, Akhil. "The Central Meaning of Republican Government: Popular Sovereignty, Majority Rule, and the Denominator Problem" (1993-1994) 65 University of Colorado Law Review 749.

. "The Consent of the Governed: Constitutional Amendment Outside of Article V" (1994) 94 Columbia Law Review 457.

Rouhana, Nadim N. "Israel and Its Arab Citizens: Predicaments in the Relationship between Ethnic States and Ethnonational Minoritites" (1998) 19:2 Third World Quarterly 277.

. "Jewish and Democratic'? The Price of a National Self-Deception" (2006) 33:2 Journal of Palestine Studies 64.

. 'Zionism's Encounter with the Palestinians: The Dynamics of Force, Fear and Extremism" in Robert I. Roteberg, ed, Narratives of Israel and Palestine: History's Double Helix (Bloomington, IN: Indiana University Press, 2006) 115.

."Reconciling History and Equal Citizenship in Israel: Democracy and the Politics of Historical Denial" in Will Kymlicka \& Bashir Bashir, eds, The Politics of Reconciliation in Multicultural Societies (Oxford: Oxford University Press, 2008) 70.

Rouhana, Nadim N. \& Nimer Sultany. "Redrawing the Boundaries of Citizenship: Israel's New Hegemony" (2003) 33:1 Journal of Palestine Studies 5.

Rubenstein, Amnon. "Israel Nationality" (1967) 2 Tel Aviv University Studies in Law 159 at 161. 
. "The Knesset and the Basic Laws on Human Rights" (in Hebrew) (2000) 5 Mishpat o Mimshal 339.

Rubenstein Amnon \& Liav Orgad. "Human Rights, State Security and Jewish Majority: The Case of Immigration for the Purpose of Marriage" (in Hebrew) (2006) 48 HaPraklit 315.

. "The Preamble to the Constitution and its Legal Status: The Case of Israel" (in Hebrew) (2007) 11 HaMishpat 79.

Saban, Ilan. "Up to the Limit of the Zionist Paradigm" in Ozacky-Lazar et al eds, Seven Roads: Theoretical Options for the Status of the Arabs in Israel (in Hebrew) (Givat Haviva: The JewishArab Center for Peace, 1999), 79.

"Minority Rights in Deeply Divided Societies: A Framework for Analysis and the Case of the Arab-Palestinian Minority in Israel" (2004) 36 New York University Journal of International Law \& Politics 885.

Sa'di, Ahmad. "Israel as Ethnic Democracy: What are the Implications for the Palestinian Minority?” (2000) 22:1 Arab Studies Quarterly 25.

. 'The Koenig Report and Israeli Policy Towards the Palestinian Minority, 1065-1976: Old Wine in New Bottles' (2003) 25:3 Arab Studies Quarterly 51.

Salzburger, Eli. "Constituent Power in Israel - Two Incidental Comments to an Obiter, or an Invitation to Re-open the Discussion" (in Hebrew) (1996) 3 Mishpat o Mimshal 679.

Sapir, Gideon. "Constitutional Revolutions: Israel as a Case-Study" (2009) 5(4) International Journal of Law in Context 355.

Shafir, Gershon. "Zionism and Colonialism: A Comparative Approach" in Ilan Pappe, ed, The Israel/Palestine Question, 2d ed (London: Routledge, 2007).

Shachar, Ayelet. "Whose Republic? Citizenship and Membership in the Israeli Polity" (1999) 12 Georgetown Immigration Law Journal 233.

Shahar, Yoram. "Earlier Drafts of the Declaration of Independence" (in Hebrew) (2002) 26:2 Iyunei Mishpat 523.

Shlaim, Avi. "The Debate About 1948" (1995) 27:3 International Journal of Middle East Studies 287.

Shteinitz, Yuval. "Democracy: The Liberal Threat" (in Hebrew) (2001) 17 Mehkari Mishpat 91.

Smooha, Sammy. "Minority Status in Ethnic Democracy: the Status of the Arab Minority in Israel" (1990) 13:3 Ethnic and Racial Studies 389. 
. "Ethnic Democracy: Israel as an Archetype” (1997) 2:2 Israel Studies 198.

. "The Regime of the State of Israel: Civil Democracy, Non-Democracy, or Ethnic Democracy?” (in Hebrew) (2000) Sociologia Yisraelit 2:2 565.

. "The Model of Ethnic Democracy: Israel as a Jewish and Democratic State" (2002)

8:4 Nations and Nationalism 475.

. "The Model of Ethnic Democracy" in Sammy Smooha \& Priit Jarve, eds, The Fate of Ethnic Democracy in Post-Communist Europe (Budapest: Open Society Foundation, 2005).

Strupler, Gila. 'Israel's Demographic Policy in the Area of Birth and Women and Minority Rights' (in Hebrew) (2006) 10 Misphat Umimshal 473.

Sultany, Nimer. "The Legacy of Justice Aharon Barak: A Critical Review" (2007) 48 Harvard International law Journal 83.

Book Review of Israel and the Family of Nations: The Jewish Nation-State and Human Rights, by Alexander Yakobson and Amnon Rubenstein, (2008-2009) 15 Palestine Yearbook of International Law 439.

Tamir, Yael. "A Jewish Democratic State" in Michael Walzer, Menachem Lorberbaum \& Noam J. Zohar, eds. The Jewish Political Tradition (New Haven \& London: Yale University Press, 2000) 518.

Tierney, Stephen. "Reframing Sovereignty? Sub-State National Societies and Contemporary Challenges to the Nation-State" (2005) 54 International \& Comparative Law Quarterly 161.

"We the Peoples': Constituent Power and Constitutionalism in Plurinational States" in Martin Loughlin \& Neil Walker, eds. The Paradox of Constitutionalism: Constituent Power and Constitutional Form (Oxford: Oxford University Press, 2007) 229

Troper, Michel. "The Survival of Sovereignty” in Hent Kalmo \& Quentin Skinner, eds, Sovereignty in Fragments: The Past, Present, and Future of a Contested Concept (Cambridge: Cambridge University Press, 2010) 139.

Tully, James. "The Struggles of Indigenous Peoples for and of Freedom" in Duncan Ivison et al, eds, Political Theory and the Rights of Indigenous Peoples (Cambridge: Cambridge University Press, 2000), 37.

. "The Unfreedom of the Moderns in Comparison to Their Ideals of Constitutional Democracy" (2002) 65 Modern Law Review 204.

. "Introduction" in Alin-G. Gagnon \& James Tully, eds, Multinational Democracies 
(Cambridge: Cambridge University Press, 2001) 1.

Van Roermund, Bert. "Sovereignty: Unpopular and Popular" in Neil Walker, ed, Sovereignty in Transition (Oxford: Hart Publishing, 2003) 40.

Waldron, Jeremy. "A Right-Based Critique of Constitutional Rights" (1993) 13:1 Oxford Journal of Legal Studies 18.

. "Precommitment and Disagreement" in Larry Alexander, ed, Constitutionalism: Philosophical Foundations (Cambridge: Cambridge University Press, 1998) 272.

Walker, Neil. "Disciplinary Perspectives" in Neil Walker, ed, Sovereignty in Transition (Oxford: Hart Publishing, 2003) 20.

Webber, Jeremy. "Democratic Decision Making as the First Principle of Contemporary Constitutionalism" in Richard Bauman \& Tsvi Kahana, eds, The Least Examined Branch: The Role of Legislatures in the Constitutional State (Cambridge: Cambridge University Press, 2006) 411.

. "The Meanings of Consent" in Jeremy Webber \& Colin M. Macleod, eds, Between Consenting People: Political Community and the Meaning of Consent (Vancouver: University of British Columbia Press, 2010) 3.

Weiler, Joseph. "Demos, Telos and the German Maastricht Decision" (1995) 1:3 European Law Journal 219.

. "Federalism Without Constitutionalism: Europe's Sonderweg" in Kalypso Nikolaidis \& Robert Howse, eds, The Federal Vision: Legitimacy and Levels of Governance in the United States and the European Union (Oxford: Oxford University Press, 2001) 54.

Weintal, Sharon. "The Challenge of Reconciling Constitutional Eternity Clauses with Popular Sovereignty: Toward Three-Track Democracy in Israel as a Universal Holistic Constitutional System and Theory" (2011) 44 Israel Law Review 449.

Wiener Antje, et at. "Global Constitutionalism: Human Rights, Democracy and the Rule of Law" (2012) 1:1 Global Constitutionalism 1.

Wolfe, Patrick. "Nation and MiscegeNation: Discursive Continuity in the Post-Mabo Era" (1994) 36 Social Analysis 93.

- "Purchase by Other Means: The Palestinian Nakba and Zionism's Conquest of Economics" (2012) 2:1 Settler Colonial Studies 133.

Yiftachel, Oren, Sandy Kedar \& Ahmad Amara, "Rereading the Doctrine of "the Dead Negev": Property Rights in the Bedouin Space" (in Hebrew) (2012) 14 Mishpat O 
Mimshal 7.

Zreik, Raef. "Notes on the Value of Theory: Readings in the Law of Return- A Polemic", online: (2008) 2:1 Law and Ethics of Human Rights 13 < http://www.degruyter.com/view/j/lehr $>$.

- "The Persistence of the Exception: Some Remarks on the Story of Israeli Constitutionalism" in Ronit Lentin, ed, Thinking Palestine (London: Zed Books, 2008) 131.

. "Why the Jewish State Now?" (2011) 40:3 Journal of Palestine Studies 23.

\section{OTHER MATERIALS}

Abdel Fattah Twafiq "Al Naqab: Al Araqib was Destroyed for the 50 48 (9 May 2013), online: <http://www.arabs48.com/?mod=articles\&ID=99632>.

“Abduction of Female Immigrants by Minorities- Urgent Discussion" (28 December 2011), available online < http://www.knesset.gov.il/protocols/data/rtf/alia/2011-12-28.rtf >

"About the Covenant", online: The Gavison-Medan Covenant <http://www.gavisonmedan.org.il/english/about/>.

Abramovitz, Amir. "Constitution by Consensus, Including, Certainly, the Consensus of the Arab Minority in Israel" (November 2004) 8 Adalah's Newsletter online: < http://www.adalah.org/newsletter/eng/dec04/IDIresponse.doc $>$.

Ad Hoc Committee on the Palestinian Question: Report of Sub-Committee 2, (11 November 1947) A/AC.14/32 (1947).

Adalah. "Nomads Against Their Will: The Attempted Expulsion of the Arab Bedouin in the Naqab: The Example of Atir Um Al- Heiran" (Haifa: Adalah, 2011), online: <http://www.adalah.org/eng/publications/Nomads\%20Against $\% 20$ their\%20Will $\% 20 \mathrm{E}$ nglish $\% 20$ pdf $\% 20$ final.pdf $>$. 2011)

"The Inequality Report: The Palestinian Arab Minority in Israel" (Haifa: Adalah, <http://adalah.org/upfiles/2011/Adalah_The_Inequality_Report March_2011.pdf>.

online:

. "The Arab Bedouin and the Prawar Plan: Ongoing Displacement in the Naqab", (2012), online, <http://ar.scribd.com/doc/122424008/The-Arab-Bedouin-and-thePrawer-Plan-Ongoing-Displacement-in-the-Naqab>.

. "From Al-Araqib to Susiya: The Forced Displacement of the Palestinians on Both Sides of the Green Line" (Haifa: Adalah, 2013), online: 
<http://adalah.org/Public/files/English/Publications/Position_Papers/ForcedDisplacement-Position-Paper-05-13.pdf $>$.

Alon, Gideon. "The 'Encouragement of Emigration for Arabs' Law was Approved for Initial Reading", Haaertr (18 February 2002), online: < http://www.haaretz.co.il/misc/1.772914>.

Amended Petition submitted by Adalah in Galon v. Minister of Interior, (2007) at para 10, online: <http://adalah.org/admin/DownLoads/SPics/6425653.pdf >.

"Announcement by the Knesset Spokesperson" (15 January 2012), online: The Knesset <http://www.knesset.gov.il/spokesman/heb/Result.asp?HodID=9579>.

Barak, Aharon. "The Values of Israel as a Jewish and Democratic State" (in Hebrew) (18 June 2002) online: <http://www.news1.co.il/archive/003-d-1202-00.html?tag=21-5348\%23ptext1767>.

Bazilai, Gad. "The Ambivalence of Litigation: A Criticism of Power" (May 2012) 13 Jadal online: http://mada-research.org/en/files/2012/05/Jadal13/Eng/Gadi-barzilai.pdf >.

Ben Yosef, Moriah. "Tel-Aviv: The Municipality Launches a Program to Prevent Relationships Between Jewish Women and Minorities" NRG Maariv (23 February 2010), online:

<http://www.nrg.co.il/online $/ 54 /$ ART2 $/ 066 / 580$. html?hp $=54 \&$ loc $=4 \& t m p=7464>$.

Central Bureau of Statistics. Press Release, " $65^{\text {th }}$ Independence Day- More than 8 Million Residents in the State of Israel" (141 April 2013) online: $<$ http://www.cbs.gov.il/reader/newhodaot/hodaa template eng.html?hodaa $=20131109$ 7>.

Committee on the Elimination of Racial Discrimination, Concluding Observations of the Committee on the Elimination of Racial Discrimination: Israel, CERD, $70^{\text {th }}$ Sess, UN Doc CERD/C/ISR/CO/13, (2007) online: <http://unispal.un.org/UNISPAL.NSF/0/041AB84D2F05080C85257302004A9963>.

"Constitution by Consensus: Proposed by the Israel Democracy Institute Under the Leadership of Justice Meir Shamgar" (Jerusalem: Israel Democracy Institute, 2007), online: <http://en.idi.org.il/media/1529178/ConstitutionByConsensus_Draft.pdf > .

"The Democratic Constitution" (Haifa: Adalah, The Legal Center for Arab Minority Rights in Israel, 2007), online: <http://adalah.org/Public/files/democratic constitutionenglish.pdf $>$.

"Demographic Growth and Settlement", online: Ministry for the Development of the Negev and

the

Galilee 
$<$ http://www.vpmo.gov.il/Negev/listProject/Pages/settlementandemogrhpy.aspx $>$.

"Discriminatory Laws in Israel", online: Adalah <http://adalah.org/eng/IsraeliDiscriminatory-Law-Database>.

"Disengagement Plan of Prime Minister Ariel Sharon - Revised" (28 May 2004), online: Knesset

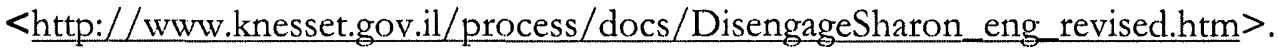

Douglas, Fredrick. "The Constitution of the United States: Is it Pro-slavery or Anti-Slavery?", online: TeachingAmericanHisotry.org $<$ http://teachingamericanhistory.org/library/index.asp?document $=1128>$.

Dreishfitz, Shourick. "Knesset Presidium" (in Hebrew) (September 2010) 66 Parliament, online: The Israel Institute for Democracy, <http://www.idi.org.il/aים.

Dworkin, Ronald. "Democracy and Religion: America and Israel" (14 September 2009), online: <http://www.youtube.com/watch?v=AU9kUlY-xUY $>$.

"Elections to the Twelfth Knesset" (1 November, 1988), online: The Knesset, $<$ http://www.knesset.gov.il/description/eng/eng_mimshal_res12.htm>.

Ettinger, Yair. "Netanyau's Office Pushing Initiative to Allow Israelis Abroad to Vote in Knesset Elections", Haaretz (23 March 2012) online: <http://www.haaretz.com/printedition/news/netanyahu-s-office-pushing-initiative-to-allow-israelis-abroad-to-vote-inknesset-elections-1.420269>.

Freedom in the World 2013: Israel", online: Freedom House $<$ http://www.freedomhouse.org/report/freedom-world/2013/israel>.

"The Future Vision of the Palestinian Arabs in Israel" (Nazareth: The National Committee of the Heads of the Arab Local Authorities, 2006), online: $<$ http://www.adalah.org/newsletter/eng/dec06/tasawor-mostaqbali.pdf >.

Gavison, Ruth. "The Justification for the Citizenship Law", (in Hebrew) Ynet (5 August 2003) online: <http://www.ynet.co.il/articles/0,7340,L-2717741,00.html>.

Conditions for the Prosperity of the State of Israel: Without a Vision, the People Will Pay the Price: A Mega Purpose for Israel and its Implications (in Hebrew) (Haifa: The Samuel Neaman Institute for Advanced Studies in Science and Technology, 2006) at 45 online: $<$ http://www.neaman.org.il/Neaman2011/userdata/SendFile.asp?.DBID=1\&LNGID $=2$ $\varepsilon \mathrm{gIID}=2136>$.

The Law of Return at Sixty Years: History, Ideology, Justification (Jerusalem: Metzilah Center for Zionist, Jewish, Liberal and Humanist Thought, 2010) online: 
$<$ http://www.metzilah.org.il/webfiles/fck/file/shvut $\% 20$ eng $\% 20$ Book\%20Final.pdf $>$.

Gross, Aeyal. "A Constitution for Israel: With Whose Consent and at Whose Expense" (January 2005) 9 Adalah's Newsletter online: $<$ http://adalah.org/newsletter/eng/jan05/ar2.pdf>.

"The Haifa Declaration" (Haifa: Mada al Carmel, 2007), online: < http://madaresearch.org/en/files/2007/09/haifaenglish.pdf>.

Hamdan Hana. "Individual Settlement in the Naqab: The Exclusion of the Arab Minority", Adalab Newsletter 10 (February 2005), online: $<$ http://adalah.org/newsletter/eng/feb05/fet.pdf $>$.

Human Rights Committee, Concluding Observations of the Human Rigbts Committee' CCPR, 99 $9^{\text {th }}$ Sess, UN Doc CCPR/C/ISR/CO/3, (2010), online: http://unispal.un.org/UNISPAL.NSF/0/51410EBD25FCE78F85257770007194A8.

Human Rights Committee, Concluding Observations of the Human Rights Committee: Israel, CCPR, $78^{\text {th }}$ Sess, UN Doc CCPR/CO/78/ISR (2003) online: http://unispal.un.org/UNISPAL.NSF/0/2E5A21A17AEB0C0285256D7F004F4D61.

Human Rights Watch, "Off the Map: Land and Housing Rights Violations in Israel's Unrecognized Bedouin Villages" (New York: Human Rights Watch, 2008) at 33-36, online: <http://www.hrw.org/reports/2008/iopt0308/iopt0308webwcover.pdf $>$.

Interview of Aharon Barak by Mordecai Krimintzer (2012) on Prof. Krimnitzer Hosting Prof. Barak, Tbird Programme, online: Israel Democarcy Institute YouTube channel $<$ http://www.youtube.com/watch?v=V6FF9ljwQyg $>$.

"Israel, the Conflict and Peace: Answers to Frequently Asked Questions" (30 December 2009), online: Israel Ministry of Foreign Affairs $<$ http://mfa.gov.il/MFA/ForeignPolicy/Peace/Guide/Pages/FAQ_Peace_process_wit h_Palestinians_Dec_2009.aspx\#Refugees1>.

The Israel Democracy Institute, "The Israeli Democracy Index 2011" Jerusalem: The Israel Democracy Institute, 2011) online: $<$ http://www.idi.org.il/sites/english/events/ThePresidentsConference/Documents/De mocracy $\% 20$ Index $\% 202011$.pdf $>$.

Israel Government Resolution no. 428 (4 April 1967).

Israel Government Resolution (11 May 1986).

"Israel's Response to the Road Map" (25 May 2003), online: The Knesset $<$ http://www.knesset.gov.il/process/docs/roadmap_response_eng.htm>. 
Jabareen, Hassan. "On Legal Advocacy and Legitimation of Control" (May 2012) 13 Jadal online: http://mada-research.org/en/files/2012/05/Jadal13/Eng/Jabarin-article.pdf $>$.

Jamal, Amal. "Litigation, Legitimation and Rethinking Counter-Hegemonic Struggle for Equality" (May 2012) 13 Jadal online: http://madaresearch.org/en/files/2012/05/Jadal13/Eng/Amal-Article.pdf > .

The Jewish People Policy Institute, "Policy Recommendations for Strengthening Jewish-Israeli Identity among Children of Israelis and their Attachment to the State of Israel and the Jewish Community" (22 March 2012) online: <h.tp://jppi.org.il/news/109/58/Strengthening-Jewish-Israeli-Identity-of-IsraelisAbroad/>.

Kimmerling, Baruch. “Constitution or Prostitution?” (January 2005) 9 Adalah's Newsletter online: <www.adalah.org/newsletter/eng/jan05/ar1.pdf>.

"Kineret Covenant", online: <http://www.hofesh.org.il/yoman/02/amanat_kinneret.html>.

Klein, Ze'ev. "Because of the Decrease in the Birth-rate: Benizri Convened the Demography Council" (3 September 2002) Globes, online: <http://www.globes.co.il/news/article.aspx?did=615868>.

Kremnitzer, Mordechai. Disqualification of Lists (in Hebrew) Jerusalem: Israel Democracy Institute, 2005) at 17 online: <http://www.idi.org.il/media/305798/pp_59.pdf>.

League of Nations, An Interim Report On The Civil Administration of Palestine during the period 1st July, 1920--30th June, 1921, (30 July 1921), online: <http://unispal.un.org/UNISPAL.NSF/0/349B02280A930813052565E90048ED1C>.

League of Nations, Report of the Palestine Royal Committee, (30 November 1937) online: <http://unispal.un.org/UNISPAL.NSF/0/08E38A718201458B052565700072B358>.

Letter from the Attorney General's Office to Adalah (20 May 2007), in Adalah Newsletter (May 2007) 36 online: <http://www.adalah.org/newsletter/eng/may07/5.php>.

Levi-Barzilai, Vered. "In Tiberias We Defined the State of the Jews" Haaretz, (1 January 2002) online: <http://www.haaretz.co.il/misc/1.760918> (in Hebrew).

Lis, Jonathan. "Lawmakers Unveil Bill Seeking to Bolster Israel's Jewish Identity", Haaretz (26 June 2013) online: < http://www.haaretz.com/news/national/.premium-1.532035>

. "Bill to Raise Knesset's Electoral Threshold Passes First Reading", Haaretz (31 July 2013) online: <http://www.haaretz.com/news/national/1.539043>.

"Livni: National aspirations of Israel's Arabs can be met by Palestinian homeland", Haaretz (11 December 2008) online: <http://www.haaretz.com/news/livni-national-aspirations- 
of-israel-s-arabs-can-be-met-by-palestinian-homeland-1.259321>.

MacIntyre, Donald. "Secret Paper Reveals EU Broadside over Plight of Israel's Arabs", The Independent (27 December 2011) online: $<$ http: $/ /$ www.independent.co.uk/news/world/europe/secret-paper-reveals-eubroadside-over-plight-of-israels-arabs-6281816.html>

Mahajna, Alaa. "Litigation Within the Israeli Court System: A Double-Edged Sword" (May 2012) 13 Jadal online: http://mada-research.org/en/files/2012/05/Jadal13/Eng/AlaaMahajna.pdf>.

Masri, Mazen. "Back to Politics?" (May 2012) 13 Jadal online: http://madaresearch.org/en/files/2012/05/Jadal13/Eng/Mazen-article2.pdf>.

The Max Planck Encyclopedia of Public International Law, "Sovereignty" by Samantha Besson, online: <www.mpepil.com>.

"Meir Kahane's speech in the Knesset on 7 June 1988", online: Memorial Website for Rabbi Kahane $<$ http: $/ /$ www.rabbikahane.org/ArticleView.aspx?id=631>.

Minister of Interior Started Revoking the Citizenship of 4 Israeli Arabs", Ynet (5 May 2009), online: <http://www.ynet.co.il/articles/0,7340,L-3711162,00.html>.

Minutes of Military Government Meeting in the Headquarters in Jaffa, Attended by Governors and the Advisor to the Prime Minister on Arab Affairs, Yoshua Palmon (27 September 1951), Tel-Aviv, Israel Defence Forces Archives (IDFA 834/53-133).

Mustafa, Mohanad. "The High Follow-up Committee and the Palestinian Situation in alDakhel" (September 2012) 15 Jadal online: <http://madaresearch.org/en/files/2012/10/mohanad-mustafa-jadal-15.pdf>.

Nahshoni, Kobi. “50 Municipal Rabbis: Don't Rent Flats to Arabs” YnetNews (12 July 2010), online: <http://www.ynetnews.com/articles/0,7340,L-3995724,00.htmll>.

"National Security", online: Israel Our Home $<$ http://www.beytenu.org/national-security $/>$.

Nesher, Talila. "Netanyahu: Israel Could be Overrun by African Infiltrators", Haaretz (21 May 2012) online: <http://www.haaretz.com/news/diplomacy-defense/netanyahu-israelcould-be-overrun-by-african-infiltrators-1.431589>.

"Palestinian Civil Society Call for BDS", (9 July 2005) online: $<$ http://www.bdsmovement.net/calls.

"Principles of the National Union Platform" online: Istael Democracy Institute

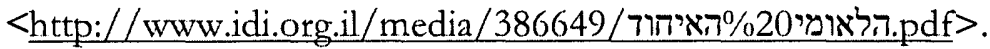


Procedure for Approval of an Application for an Immigrant Visa Another Time in Israel and Overseas Missions, Procedure number 5.2.0002) (1 August 2005) online: <http://piba.gov.il/Regulations/67.pdf $>$.

Protocol No. 366 Meeting of Constitution, Law and Justice Committee, (22 October 2001).

Protocol No. 461 Meeting of the Constitution, Law and Justice Committee, (30 April 2002).

Sheperman, Karin Tamar. "Participation, Abstention and Boycott: Trends in the Participation of the Arab Citizens of Israel in the Knesset Elections" (March 2009) 61 Parliament, online: The Israel Democracy Institute <http://www.idi.org.il/o-אזרחי-הערבים-של-בהשתתפותם-מגמות-והחרמה-הימנעות-,השתתפות/D1/ק-גיליון/פרלמנט/ומאמרים

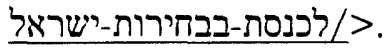

The Stanford Encyclopedia of Philosopby (Fall 2011 Edition), "Rights" by Wenar Leif online: <http://plato.stanford.edu/archives/fall2011/entries/rights/>.

The Stanford Encyclopedia of Pbilosopby (Summer 2010 Edition), 'Sovereignty" by Dan Philpott, online: <http://plato.stanford.edu/archives/sum2010/entries/sovereignty>.

State Service Commission, Appropriate Representation for the Arab Population including the Druze and Circassians: Report for the Year 2011, online: <http://www.civilservice.gov.il/NR/rdonlyres/2FCC4CD2-01DD-4FFB-B2B7CEB995FE0F9F $/ 0 /$ representation2011.pdf $>$.

Statistical Abstract of Israel 2012 (Jerusalem: Central Bureau of Statistics, 2013).

Sofer, Arnon \& Yevgenia Bisrov. The State of Tel-Aviv- A Threat to Israel, 2nd ed (Haifa: Haifa University, 2008) online <http://web.hevra.haifa.ac.il/ chstrategy/images/publications/Tel Aviv 2008.pdf $>$.

Ravid, Barak. "Leiberman: Peace Talks Must Reassess Israeli-Arabs' Right to Citizenship" Haaretz (19 September 2010), online <http://www.haaretz.com/news/diplomacydefense/lieberman-peace-talks-must-reassess-israeli-arabs-right-to-citizenship-1.314596>.

Table of Assistance Amounts of Absorption Basket, online: Ministry of Immigration Absorption $<$ http://www.moia.gov.il/English/Subjects/FinancialAssistance/Pages/TableAmountsB asket.aspx $>$.

Robinson, Shira Nomi. Occupied Citizens in a Liberal State: Palestinians Under Military Rule and the Colonial Formation of Israeli Society, 1948-1966 (PhD Dissertation, Stanford University, 2005) [unpublished].

Rouhana, Nadim N. "'Constitution by Consensus': By Whose Consensus" (November 2004) 7 Adalah'a Newsletter online: http://www.adalah.org/newsletter/eng/nov04/ar1.pdf>. 
. "The Jewish Institute for Ethnic Democracy" (January 2005) 9 Adalah's Newsletter online: <http://www.adalah.org/newsletter/eng/jan05/ar3.pdf >.

. "The Shrinking Arab Vote in Israeli Parliamentary Elections: But Why Do they Still Vote?" (March 2009) 2 Jadal 20, online: <http://madaresearch.org/en/files/2009/03/jadal2/jadal2-eng-fail/Jadal_Mar09_Eng-final1.pdf >.

UK, HC, "Palestine Statement of Policy", Cmd. 6019 (1 May 1939) available online < http://unispal.un.org/UNISPAL.NSF/0/EB5B88C94ABA2AE585256D0B00555536>

United Nations Special Committee on Palestine, Report to the General Assembly, UNGAOR, (3 September 1947), sup No 11, A/364, online: < http://unispal.un.org/UNISPAL.NSF/0/07175DE9FA2DE563852568D3006E10F3>

UNGAOR, 1949, $44^{\text {th }}$ meeting, UN doc A/AC.24/SR.45, online: < http://unispal.un.org/unispal.nsf/9a798adbf322aff38525617b006d88d7/1db943e43c28 0a26052565fa004d8174? OpenDocument $>$.

"Voting Percentages in Past Elections" (2009) online: The Central Elections Committee $<$ http://www.bechirot.gov.il/elections19/eng/history/PercentVotes eng.aspx $>$.

Weis, Efrat \& Ilan Marciano. "Eitam: To Expel the Arabs from the [West] Bank- and from the Knesset" Ynet (11 June 2006), online: <http://www.ynet.co.il/articles/0,7340,L$\underline{3302258,00 . h t m l}>$.

Yagna, Yanir \& Jonathan Lis. "Bedouin Relocation Plan Wins Slim Knesset Majority after Stormy $1^{\text {st }}$ Reading", Haaretz (24 June 2013) online: <http://www.haaretz.com/news/national/.premium-1.531794>. 


\section{Appendix "A"}

\section{The Declaration of the Establishment of the State of Israel}

The Land of Israel was the birthplace of the Jewish people. Here their spiritual, religious and political identity was shaped. Here they first attained to statehood, created cultural values of national and universal significance and gave to the world the eternal Book of Books.

After being forcibly exiled from their land, the people kept faith with it throughout their Dispersion and never ceased to pray and hope for their return to it and for the restoration in it of their political freedom.

Impelled by this historic and traditional attachment, Jews strove in every successive generation to re-establish themselves in their ancient homeland. In recent decades they returned in their masses. Pioneers, defiant returnees, and defenders, they made deserts bloom, revived the Hebrew language, built villages and towns, and created a thriving community controlling its own economy and culture, loving peace but knowing how to defend itself, bringing the blessings of progress to all the country's inhabitants, and aspiring towards independent nationhood.

In the year 5657 (1897), at the summons of the spiritual father of the Jewish State, Theodore Herzl, the First Zionist Congress convened and proclaimed the right of the Jewish people to national rebirth in its own country.

This right was recognized in the Balfour Declaration of the 2nd November, 1917, and reaffirmed in the Mandate of the League of Nations which, in particular, gave international sanction to the historic connection between the Jewish people and Eretz-Israel and to the right of the Jewish people to rebuild its National Home.

The catastrophe which recently befell the Jewish people - the massacre of millions of Jews in Europe - was another clear demonstration of the urgency of solving the problem of its homelessness by re-establishing in Eretz-Israel the Jewish State, which would open the gates of the homeland wide to every Jew and confer upon the Jewish people the status of a fully privileged member of the community of nations.

Survivors of the Nazi holocaust in Europe, as well as Jews from other parts of the world, continued to migrate to Eretz-Israel, undaunted by difficulties, restrictions and dangers, and never ceased to assert their right to a life of dignity, freedom and honest toil in their national homeland.

In the Second World War, the Jewish community of this country contributed its full share to the struggle of the freedom- and peace-loving nations against the forces of Nazi wickedness and, by the blood of its soldiers and its war effort, gained the right to be reckoned among the peoples who founded the United Nations.

On the 29th November, 1947, the United Nations General Assembly passed a resolution 
calling for the establishment of a Jewish State in Eretz-Israel; the General Assembly required the inhabitants of Eretz-Israel to take such steps as were necessary on their part for the implementation of that resolution. This recognition by the United Nations of the right of the Jewish people to establish their State is irrevocable.

This right is the natural right of the Jewish people to be masters of their own fate, like all other nations, in their own sovereign State.

Accordingly we, members of the People's Council, representatives of the Jewish Community of Eretz-Israel and of the Zionist Movement, are here assembled on the day of the termination of the British Mandate over Eretz-Israel and, by virtue of our natural and historic right and on the strength of the resolution of the United Nations General Assembly, hereby declare the establishment of a Jewish state in Eretz-Israel, to be known as the State of Israel.

We declare that, with effect from the moment of the termination of the Mandate being tonight, the eve of Sabbath, the 6th Iyar, 5708 (15th May, 1948), until the establishment of the elected, regular authorities of the State in accordance with the Constitution which shall be adopted by the Elected Constituent Assembly not later than the 1st October 1948, the People's Council shall act as a Provisional Council of State, and its executive organ, the People's Administration, shall be the Provisional Government of the Jewish State, to be called "Israel." The State of Israel will be open for Jewish immigration and for the Ingathering of the Exiles; it will foster the development of the country for the benefit of all its inhabitants; it will be based on freedom, justice and peace as envisaged by the prophets of Israel; it will ensure complete equality of social and political rights to all its inhabitants irrespective of religion, race or sex; it will guarantee freedom of religion, conscience, language, education and culture; it will safeguard the Holy Places of all religions; and it will be faithful to the principles of the Charter of the United Nations.

The State of Israel is prepared to cooperate with the agencies and representatives of the United Nations in implementing the resolution of the General Assembly of the 29th November, 1947, and will take steps to bring about the economic union of the whole of Eretz-Israel.

We appeal to the United Nations to assist the Jewish people in the building-up of its State and to receive the State of Israel into the community of nations.

We appeal - in the very midst of the onslaught launched against us now for months - to the Arab inhabitants of the State of Israel to preserve peace and participate in the upbuilding of the State on the basis of full and equal citizenship and due representation in all its provisional and permanent institutions.

We extend our hand to all neighbouring states and their peoples in an offer of peace and good neighbourliness, and appeal to them to establish bonds of cooperation and mutual help with the sovereign Jewish people settled in its own land. The State of Israel is prepared to do its share in a common effort for the advancement of the entire Middle East. 
We appeal to the Jewish people throughout the Diaspora to rally round the Jews of EretzIsrael in the tasks of immigration and upbuilding and to stand by them in the great struggle for the realization of the age-old dream - the redemption of Israel.

Placing our trust in the Almighty, we affix our signatures to this proclamation at this session of the provisional Council of State, on the soil of the Homeland, in the city of Tel-Aviv, on this Sabbath eve, the 5th day of Iyar, 5708 (14th May, 1948).

\section{David Ben-Gurion}

Daniel Auster Mordekhai Bentov Yitzchak Ben Zvi Eliyahu Berligne Fritz Bernstein Rabbi Wolf Gold Meir Grabovsky Yitzchak Gruenbaum Dr. Abraham Granovsky Eliyahu Dobkin Meir Wilner-Kovner Zerach Wahrhaftig Herzl Vardi Rachel Cohen Rabbi Kalman Kahana Saadia Kobashi Rabbi Yitzchak Meir Levin Meir David Loewenstein Zvi Luria Golda Myerson Nachum Nir Zvi Segal Rabbi Yehuda Leib Hacohen Fishman David Zvi Pinkas Aharon Zisling Moshe Kolodny Eliezer Kaplan Abraham Katznelson Felix Rosenblueth David Remez Berl Repetur Mordekhai Shattner Ben Zion Sternberg Bekhor Shitreet Moshe Shapira Moshe Shertok

Source: The Knesset, online: <http://www.knesset.gov.il/docs/eng/megilat_eng.htm>. 


\section{Appendix "B" \\ The Law of Return- 1950}

\section{Right of "aliya"}

Every Jew has the right to come to this country as an "oleh".

\section{Oleh's visa}

(a)Aliya shall be by oleh's visa.

(b)an oleh's visa shall be granted to every Jew who has expressed his desire to settle in Israel, unless the Minister of the Interior is satisfied that the applicant -

(1)is engaged in an activity directed against the Jewish people;

(2)is likely to endanger public health or the security of the State; or

(3)is a person with criminal past, likely to endanger public welfare.

\section{Oleh's certificate}

(a)A Jew who has come to Israel and subsequent to his arrival has expressed his desire to settle in Israel may, while still in Israel, receive an oleh's certificate.

(b)The restrictions specified in section 2(b) shall apply also to the grant of an oleh's certificate, but a person shall not be regarded as endangering public health on account of an illness contracted after his arrival in Israel.

\section{Residents and persons born in this country}

Every Jew who has immigrated into this country before the coming into force of this Law, and every Jew who was born in this country, whether before or after the coming into force of this Law, shall be deemed to be a person who has come to this country as an oleh under this Law.

\section{A. Rights of members of family}

(a)The rights of a Jew under this Law and the rights of an oleh under the Nationality Law, 5712--1952), as well as the rights of an oleh under any other enactment, are also vested in a child and a grandchild of a Jew, the spouse of a Jew, the spouse of a child of a Jew and the spouse of a grandchild of a Jew, except for a person who has been a Jew and has voluntarily changed his religion.

(b)It shall be immaterial whether or not a Jew by whose rights a right under subsection (a) is claimed is still alive and whether or not he has immigrated to Israel.

(c)The restrictions and conditions prescribed in respect of a Jew or an oleh by or under this Law or by the enactments referred to in subsection (a) shall also apply to a person who claims a right under subsection (a).

\section{B. Definition}

For the purpose of this Law, "Jew" means a person who was born of a Jewish mother or has become converted to Judaism and who is not a member of another religion. 


\section{Implementation and regulations}

The Minister of the Interior is charged with the implementation of this Law and may make regulations as to any matter relating to such implementation and also as to the grant of oleh's visa and oleh's certificates to minors up to the age of 18 years. Regulations for the purposes of section $4 \mathrm{~A}$ and $4 \mathrm{~B}$ require the approval of the Constitution, Legislation and Judicial Committee of the Knesset.

Source: United Nations High Commissioner for Refugees, online: <http://www.refworld.org/docid/3ae6b4ea1b.html $>$. 


\section{Appendix "C"}

\section{Basic Law: Human Dignity and Liberty}

1. Fundamental human rights in Israel are founded upon recognition of the value of the human being, the sanctity of human life, and the principle that all persons are free; these rights shall be upheld in the spirit of the principles set forth in the Declaration of the Establishment of the State of Israel.

Purpose

1A. The purpose of this Basic Law is to protect human dignity and liberty, in order to establish in a Basic Law the values of the State of Israel as a Jewish and democratic state.

Preservation of life, body and dignity

2. There shall be no violation of the life, body or dignity of any person as such.

Protection of property

3. There shall be no violation of the property of a person.

Protection of life, body and dignity

4. All persons are entitled to protection of their life, body and dignity.

Personal liberty

5. There shall be no deprivation or restriction of the liberty of a person by imprisonment, arrest, extradition or otherwise.

Leaving and entering Israel

6. (a) All persons are free to leave Israel.

(b) Every Israel national has the right of entry into Israel from abroad.

Privacy

7. (a) All persons have the right to privacy and to intimacy.

(b) There shall be no entry into the private premises of a person who has not consented thereto.

(c) No search shall be conducted on the private premises of a person, nor in the body or personal effects.

(d) There shall be no violation of the confidentiality of conversation, or of the writings or records of a person.

Violation of rights

8. There shall be no violation of rights under this Basic Law except by a law befitting the values of the State of Israel, enacted for a proper purpose, and to an extent no greater than is required or by regulation enacted by virtue of express authorization in such law. 
Reservation regarding security forces

9. There shall be no restriction of rights under this Basic Law held by persons serving in the Israel Defence Forces, the Israel Police, the Prisons Service and other security organizations of the State, nor shall such rights be subject to conditions, except by virtue of a law, or by regulation enacted by virtue of a law, and to an extent no greater than is required by the nature and character of the service.

Validity of laws

10. This Basic Law shall not affect the validity of any law (din) in force prior to the commencement of the Basic Law.

Application

11. All governmental authorities are bound to respect the rights under this Basic Law.

Stability

12. This Basic Law cannot be varied, suspended or made subject to conditions by emergency regulations; notwithstanding, when a state of emergency exists, by virtue of a declaration under section 9 of the Law and Administration Ordinance, 5708-1948, emergency regulations may be enacted by virtue of said section to deny or restrict rights under this Basic Law, provided the denial or restriction shall be for a proper purpose and for a period and extent no greater than is required.

Source: The Knesset, online: http://www.knesset.gov.il/laws/special/eng/basic3_eng.htm 


\section{Appendix "D"}

\section{Basic Law: Freedom of Occupation}

Basic principles

1. Fundamental human rights in Israel are founded upon recognition of the value of the human being, the sanctity of human life, and the principle that all persons are free; these rights shall be upheld in the spirit of the principles set forth in the Declaration of the Establishment of the State of Israel.

Purpose

2. The purpose of this Basic Law if to protect freedom of occupation, in order to establish in a Basic Law the values of the State of Israel as a Jewish and democratic state.

Freedom of occupation.

3. Every Israel national or resident has the right to engage in any occupation, profession or trade.

Violation of freedom of occupation

4. There shall be no violation of freedom of occupation except by a law befitting the values of the State of Israel, enacted for a proper purpose, and to an extent no greater than is required, or by regulation enacted by virtue of express authorisation in such law.

Application

5. All governmental authorities are bound to respect the freedom of occupation of all Israel nationals and residents.

Stability

6. This Basic Law shall not be varied, suspended or made subject to conditions by emergency regulations.

\section{Entrenchment}

7. This Basic Law shall not be varied except by a Basic Law passed by a majority of the members of the Knesset.

Effect of nonconforming law

8. A provision of a law that violates freedom of occupation shall be of effect, even though not in accordance with section 4 , if it has been included in a law passed by a majority of the members of the Knesset, which expressly states that it shall be of effect, notwithstanding the provisions of this Basic Law; such law shall expire four years from its commencement unless a shorter duration has been stated therein. 
Repeal

9. Basic Law: Freedom of Occupation (1992) is hereby repealed.

\section{Provisional}

10. The provisions of any enactment which, immediately prior to this Basic Law would have been of effect but for this Basic Law or the Basic Law repealed in section 9, shall remain in effect two years from the commencement of this Basic Law, unless repealed earlier; however, such provisions shall be construed in the spirit of the provisions of this Basic Law.

Source: The Knesset, online: http://www.knesset.gov.il/laws/special/eng/basic4 eng.htm 